\title{
AVALIAÇÃO DA TÉCNICA DE RÉPLICA \\ PARA ANÁLISE IN VITRO E IN VIVO DAS ALTERAÇÕES \\ DA SUPERFÍCIE DA DENTINA HIPERESTÉSICA E \\ TRATADA COM OXALATO DE POTÁSSIO
}

\section{ANA CHRISTINA BONATO FIGUEIREDO MARTINELI}

Tese apresentada à Faculdade de Odontologia de Bauru, da Universidade de São Paulo, como parte dos requisitos para obtenção do título de Doutora em Odontologia - Área de concentração: Dentística.

(Edição Revisada) 


\section{AVALIAÇÃO DA TÉCNICA DE RÉPLICA \\ PARA ANÁLISE IN VITRO E IN VIVO DAS ALTERAÇÕES \\ DA SUPERFÍCIE DA DENTINA HIPERESTÉSICA E \\ TRATADA COM OXALATO DE POTÁSSIO}

\section{ANA CHRISTINA BONATO FIGUEIREDO MARTINELI}

Tese apresentada à Faculdade de Odontologia de Bauru, da Universidade de São Paulo, como parte dos requisitos para obtenção do título de Doutora em Odontologia - Área de concentração: Dentística.

(Edição Revisada)

Orientador:

Prof. Dr. CARLOS EDUARDO FRANCISCHONE 
Martineli, Ana Christina Bonato Figueiredo

M366a Avaliação da técnica de réplica para análise in vitro $e$ in vivo das alterações da superfície da dentina hiperestésica e tratada com oxalato de potássio / Ana Christina Bonato Figueiredo Martineli. -- Bauru, 2002. 197 p.; $30 \mathrm{~cm}$.

Tese (Doutorado) -- Faculdade de Odontologia de Bauru. USP.

Orientador: Prof. Dr. Carlos Eduardo Francischone.

Autorizo, exclusivamente para fins acadêmicos e científicos, a reprodução total ou parcial desta tese, por processos fotocopiadores e/ou meios eletrônicos.

Assinatura da autora:

Data: 


\section{ANA CHRISTINA BONATO FIGUEIREDO MARTINELI}

23 de dezembro de 1969

Marília - SP

$1988-1991$

1994

1997

$1997-1999$

$1999-2002$

Associações
Nascimento

Curso de Odontologia - Faculdade de Odontologia da Universidade de Marília, SP.

Curso de Especialização em Dentística, na Faculdade de Odontologia de Bauru - Universidade de São Paulo.

Professora auxiliar do Departamento de Clínica Integrada da Faculdade de Odontologia da Universidade de Marília, SP.

Professora auxiliar do Departamento de Dentística da Faculdade de Odontologia da Universidade de Marília, SP.

Curso de Pós-Graduação em Dentística, em nível de Mestrado, na Faculdade de Odontologia de Bauru USP.

Curso de Pós-Graduação em Dentística, em nível de Doutorado, na Faculdade de Odontologia de Bauru USP.

* Associação Paulista de Cirurgiões Dentistas (APCD)- Regional de Marília * Sociedade Brasileira de Pesquisas Odontológicas (SBPqO)

* International Association for Dental Research (IADR)

* Grupo Brasileiro de Professores de Dentística - GBPD 
"No porto de antes, apreensivo, eu tentava imaginar as dificuldades e lutas futuras. No de agora, dono do tempo que eu conquistara, simplesmente admirava o que estava ao redor e desfrutava do que estava feito. Não era a sensação de uma batalha ganha, de uma luta em que os obstáculos foram vencidos. Muito mais do que isso, era o prazer interior de ter realizado algo que tanto desejei, de ter feito e visto o que fiz e vi".

"Um homem precisa viajar. Por sua conta, não por meio de histórias, imagens, livros. Precisa viajar por si, com seus olhos e pés, para entender o que é seu. Para um dia plantar suas próprias árvores e dar-Ihes valor. Conhecer o frio para desfrutar do calor. E o oposto. Sentir a distância e o desabrigo para estar bem sob o próprio teto. Um homem precisa viajar para lugares que não conhece para quebrar essa arrogância que nos faz ver o mundo como imaginamos, e não simplesmente como é ou pode ser; que nos faz professores e doutores do que não vimos, quando deveríamos ser alunos, e simplesmente ir ver.... É preciso ir tocá-lo". 


\section{À minha querida mãe,}

Sempre, em momentos assim, me faltam palavras....

Se eu pudesse escrever tudo o que sinto, transformar letras em emoção real... Como uma simples folha em branco pode ser preenchida com sentimentos?

Então pensei: quando nasci, era como uma "folha em branco", pronta para receber qualquer rabisco, um rascunho qualquer. Mas em mim foram gravadas palavras.

Palavras doces, como amor, carinho, ternura...

Palavras fortes, como verdade, honestidade, trabalho...

Não foi escrito preguiça, nem medo... Escreveu-se coragem, escreveu-se respeito. E essas palavras, a mensagem de minha vida, formaram minha história.

Por isso, mãe, eu dedico a você toda a emoção dessa minha conquista.

Sem você, seu apoio, sua força, sua dedicação e, principalmente seu exemplo, eu não teria conseguido.

Eu te amo. 
A você, Val

\author{
Tu, alma minha, meu coração, \\ $T u$, meu encanto e minha paixão, \\ Mundo meu, a quem me circunscrevo, \\ Tu, alto céu a que me elevo.... \\ Tu és a paz, tu és a calma, \\ O céu prometido à minha alma. \\ Quanto me estimas, é o que valho; \\ Teu olhar é que me faz claro. \\ Tu me ergues muito além de mim, \\ Meu lado bom, meu querubim.
}

Goethe

"Alma Minha, Coração Meu"

Por compreender e aceitar os momentos de ausência, e por sempre me dedicar tanto amor. Essa conquista também é sua.

Eu também te amo, muito.

\title{
Ao meu filho,
}

Você, que ainda nem nasceu, já é toda a minha força, meu motivo, toda causa e conseqüência.

Eu já te amo tanto.... 
Agradeço especialmente,

\section{Ao meu pai,}

Por tanto amor, carinho, atenção, preocupação, e por estar sempre disposto a ouvir minhas histórias...

Eu te amo muito.

Ao meu irmão,

Que, mesmo tão longe, está sempre tão presente...

pelo carinho, pelo exemplo de coragem e perseverança,

e pela vontade de também estar aqui.

Eu te amo. 


\section{Ao Prof. Dr. Carlos Eduardo Francischone,}

Meus agradecimentos sinceros pelo apoio, constante estímulo, e confiança que em mim depositou durante a realização desse trabalho.

"Mais que o ato mágico do artista,

Que do primitivo cria o belo,

O educador detona o processo criador.

Ele não faz: dá condições para que seja feito;

Ele não manipula: estimula;

Ele não domina: liberta.

Assim, ele é um fazedor de gente"

Morrie Schwartz "A Última Grande Lição" 


\section{Ao Prof. Dr. José Carlos Pereira,}

Uma nova etapa vencida. Mais uma vez, agradeço a atenção e a amizade que o senhor demonstrou durante todo o curso e, sobretudo, a oportunidade de crescimento pessoal e profissional. O senhor será sempre um exemplo a ser seguido. Com admiração, meu muito obrigada.

"O professor se liga à eternidade;

ele nunca sabe onde cessa a sua influência".

Henry Adams 
Agradeço também,

Aos meus colegas do curso de Doutorado, em especial ao Sérgio, Juliana, Juliano e Ranulfo, pelos momentos especiais que passamos juntos, "aprendendo de tudo, inclusive odontologia".

Ao Edimauro, por ter feito as fotomicrografias, agradeço a disponibilidade e a simpatia com que sempre me atendeu. Sem sua ajuda, teria sido muito difícil realizar esse trabalho.

A todos os Professores e Funcionários do Departamento de Dentística da Faculdade de Odontologia de Bauru - USP, que dedicaram seu tempo sempre que precisei.

À Profa. Dra. Maria Fidela de Lima Navarro, por todas as oportunidades de crescimento profissional concedidas durante o curso, e pelo constante exemplo de amor ao ensino e dedicação à Faculdade de Odontologia de Bauru.

À Dra. Simone e ao Dr. João Augusto, cirurgiões-dentistas do Hospital de Clínicas da Faculdade de Medicina de Marília - FAMEMA, por toda a ajuda durante a execução deste trabalho.

Aos funcionários da secretaria de Pós-graduação da Faculdade de Odontologia de Bauru, em especial ao Aurélio e Giane, que sempre me atenderam com eficiência e cordialidade.

Aos funcionários da Biblioteca da Faculdade de Odontologia de Bauru, em especial à Cybelle e à Valéria.

Aos meus colegas da Disciplina de Dentística da Faculdade de Ciências Odontológicas da Universidade de Marília, Professores Luís Anselmo, Lúcia Helena e Roque.

Aos pacientes que participaram desta pesquisa.

À CAPES, pela concessão da Bolsa.

A todos que tornaram possível a conclusão deste trabalho.

Meu muito obrigada. 


\section{SUMÁRIO}

\section{LISTA DE FIGURAS}

\section{RESUMO}

1 INTRODUÇÃO

2 REVISÃO DA LITERATURA 6

2.1 TÉCNICA DE RÉPLICA 6

Definição, Nomenclatura e Princípios 6

Aplicações da Técnica de Réplica em Odontologia 12

2.2 HIPERESTESIA DENTINÁRIA 46

Mecanismos da Hiperestesia Dentinária 46

Formas de Tratamento - Obliteração dos Túbulos Dentinários 50

Efeito Placebo 53

2.3 OXALATO DE POTÁSSIO

Estudos Laboratoriais $\quad 54$

Estudos Clínicos $\quad 65$

3 PROPOSIÇÃO

4 MATERIAL E MÉTODO 83

4.1 ESTUDO IN VITRO 83

Seleção dos Dentes e Obtenção dos Discos de Dentina 83

Tratamento dos Discos de Dentina 84

Moldagem e Obtenção das Réplicas $\quad 85$

4.2 ESTUDO IN VIVO 86

Comitê de Ética em Pesquisa $\quad 86$

Seleção dos Pacientes $\quad 87$

Seleção dos Dentes $\quad 88$

Determinação dos Padrões de Hiperestesia $\quad 89$

Técnica de Moldagem $\quad 91$

Obtenção das Réplicas 93 
5 RESULTADOS 95

5.1 ESTUDO IN VITRO 95

5.2 ESTUDO IN VIVO 102

Interpretação das Imagens 102

Grupo $1 \quad 108$

Grupo $2 \quad 122$

6 DISCUSSÃO 134

6.1 DISCUSSÃO DA METODOLOGIA 134

6.1.1 ESTUDO IN VITRO 135

6.1.2 ESTUDO IN VIVO 138

6.2 DISCUSSÃO DOS RESULTADOS 153

6.2.1 ESTUDO IN VITRO 153

6.2.2 ESTUDO IN VIVO 155

GRUPO 1

GRUPO 2

6.3 CONSIDERAÇÕES FINAIS 162

7 CONCLUSÕES 165

$\begin{array}{ll}\text { ANEXOS } & 167\end{array}$

REFERÊNCIAS BIBLIOGRÁFICAS

$\begin{array}{ll}\text { ABSTRACT } & 196\end{array}$ 
Figura 2.1: Agentes e procedimentos com efeito oclusivo sobre os canalículos dentinários

Figura 4.1: Distribuição dos dentes por grupos

Figura 5.1: Relação de pacientes, Dentes, Grau de Sensibilidade inicial e final e Espécimes do Grupo 1

Figura 5.2: Relação de pacientes, Dentes, Grau de Sensibilidade e Espécimes do Grupo 2

Figura 1A: Fotomicrografia eletrônica de varredura do disco de dentina. Os túbulos dentinários estão completamente cobertos por smear layer. (Barra $=10 \mu \mathrm{m}, \mathrm{X} 1000)$.

Figura 2A: Fotomicrografia eletrônica de varredura do molde (réplica negativa) do disco de dentina. Podem ser observadas algumas curtas projeções do material de moldagem. (Barra $=10 \mu \mathrm{m}, \mathrm{X} 1000)$.

Figura 3A: Fotomicrografia eletrônica de varredura da réplica positiva do disco de dentina. As mesmas características da smear layer do espécime original podem ser observadas. (Barra $=10 \mu \mathrm{m}$, $\mathrm{X} 1000)$.

Figura 1B: Fotomicrografia eletrônica de varredura do disco de dentina após o condicionamento ácido. A smear layer foi completamente removida, revelando túbulos dentinários abertos. Podem ser vistos remanescentes de material de moldagem (setas). $($ Barra $=10 \mu \mathrm{m}, \mathrm{X} 1000)$.

Figura 2B: Fotomicrografia eletrônica de varredura do molde (réplica negativa) do disco de dentina condicionado com ácido. Observam-se longas projeções de silicona formadas pela penetração profunda do material de moldagem nos túbulos dentinários. (Barra $=10 \mu \mathrm{m}$, $\mathrm{X} 1000)$.

Figura 3B: Fotomicrografia eletrônica de varredura da réplica positiva do disco de dentina condicionado com ácido. Uma superfície limpa, túbulos dentinários abertos e alguns artefatos podem ser observados. (Barra $=10 \mu \mathrm{m}, \mathrm{X} 1000)$. 
Figura 1C: Fotomicrografia eletrônica de varredura do disco de dentina após o tratamento com Oxa-Gel ${ }^{\circledR}$. As aberturas dos túbulos dentinários encontram-se parcialmente ocluídas por precipitação de cristais (setas pretas), e outros túbulos estão obstruídos por tags de silicona (setas brancas) (Barra $=10 \mu \mathrm{m}, \mathrm{X1000}$ ).

Figura 2C: Fotomicrografia eletrônica de varredura do molde (réplica negativa) do disco de dentina. Podem ser observados tags de silicona curtos e eretos devido à obliteração dos túbulos dentinários. $($ Barra $=10 \mu \mathrm{m}, \mathrm{X} 1000)$.

Figura 3C: : Fotomicrografia eletrônica de varredura da réplica positiva do disco de dentina após o tratamento com Oxa-Gel ${ }^{\circledR}$. A réplica foi capaz de copiar os cristais precipitados (setas pretas) e, ainda, outros túbulos obliterados por fragmentos de silicona (setas brancas) (Barra $=10 \mu \mathrm{m}, \mathrm{X} 1000)$.

Figura 1D: Fotomicrografia eletrônica de varredura do disco de dentina após o tratamento com Oxa-Gel ${ }^{\circledR}$ e condicionado com ácido novamente. Alguns dos depósitos na abertura dos túbulos foram removidos, e o material de moldagem remanescente ainda mantém alguns túbulos fechados (setas). (Barra $=10 \mu \mathrm{m}, \mathrm{X1000}$ ).

Figura 2D: Fotomicrografia eletrônica de varredura do molde (réplica negativa) do disco de dentina após o tratamento com Oxa-Gel ${ }^{\circledR}$ e condicionado com ácido novamente. Podem ser observados tags retorcidos de silicona e alguns curtos e rompidos. (Barra $=10 \mu \mathrm{m}$, X1000).

Figura 3D: Fotomicrografia eletrônica de varredura da réplica do disco de dentina após o tratamento com Oxa-Gel ${ }^{\circledR}$ e recondicionamento com ácido. Pequenas aberturas de túbulos dentinários e sinais da precipitação de cristais podem ser vistos (setas pretas). Outros túbulos permanecem obstruídos por silicona remanescente (setas brancas) (Barra $=10 \mu \mathrm{m}, \mathrm{X} 1000$ ).

Figura 4: Fotomicrografia eletrônica de varredura da réplica negativa (molde) da superfície de dentina hiperestésica com aumento de 1000X, vista de topo. Note-se a presença de inúmeros túbulos dentinários com diferentes diâmetros, os quais poderiam ser classificados, num primeiro momento, como túbulos abertos (setas brancas) ou fechados (setas pretas).

Figura 5: Fotomicrografia eletrônica de varredura da réplica negativa (molde) da mesma superfície de dentina hiperestésica. Em maior aumento (X3500), as imagens apontadas pelas setas brancas parecem ser o negativo de uma superfície em relevo. As estruturas apontadas por setas pretas podem ser interpretadas como sendo a imagem de túbulos dentinários fechados. 
Figura 6: Fotomicrografia eletrônica de varredura da réplica negativa (molde) da mesma superfície de dentina hiperestésica, com aumento de 5000X. As imagens apontadas pelas setas brancas parecem ser 0 negativo de uma superfície em relevo, e as estruturas apontadas por setas pretas podem ser interpretadas como sendo a imagem de túbulos dentinários fechados.

Figura 7: Microscopia eletrônica de varredura da réplica negativa (molde) da superfície de dentina hiperestésica, com aumento de 1000X e inclinação de $50^{\circ}$. Nessa angulação, pode-se observar a imagem de túbulos dentinários, mas com características e diâmetros diferentes.

Figura 8: Fotomicrografia eletrônica de varredura da réplica negativa (molde) da superfície de dentina hiperestésica, com aumento de 3500X e inclinação de $50^{\circ}$. Pode-se observar que o material de moldagem penetrou mais em alguns túbulos (setas brancas) e menos em outros túbulos (setas pretas).

Figura 9: Microscopia eletrônica de varredura da réplica negativa (molde) da superfície de dentina hiperestésica, com aumento de 5000X e inclinação de $50^{\circ}$. Os mesmos padrões de projeção do material de moldagem podem ser observados (setas brancas). As setas pretas indicam a imagem de uma superfície côncava, podendo ser interpretada como a réplica negativa de gotículas de fluido dentinário.

Figura 10: Desenho representativo $(A)$ dos diferentes padrões de projeção do material de moldagem no interior dos túbulos dentinários, que podem ser observados na fotomicrografia (B). O padrão 1 representa a situação em que o material de moldagem penetrou mais profundamente na embocadura do túbulo dentinário, podendo ou não apresentar pequenas bolhas. No padrão 2, o material de moldagem penetrou no túbulo dentinário, justapondo-se às suas paredes. A pressão hidráulica no interior dos túbulos deslocou o material de volta, exceto na área periférica, onde o material permaneceu aderido às paredes da dentina, dando a essa imagem a aparência de anel. $\mathrm{O}$ padrão 3 representa a situação em que a pressão do fluido dentinário não permitiu a penetração do material de moldagem no túbulo, resultando em uma imagem sugestiva do molde das gotículas do próprio fluido dentinário.

Figura 11A: Fotomicrografia eletrônica de varredura da réplica negativa da superfície dentinária de um paciente com desconforto extremo $(10,0)$ inicial para ambos os estímulos (sonda exploradora e jato de ar). Observe-se a grande quantidade de túbulos dentinários total ou parcialmente abertos, característicos de dentina hiperestésica. 
Figura 11B: Fotomicrografia eletrônica de varredura da réplica negativa da mesma superfície após 4 aplicações de Oxa-Gel ${ }^{\circledR}$. Notase que os túbulos dentinários estão em menor número. Apesar da melhora relatada pelo paciente $(0,5$ ao estímulo sonda e 7,5 ao estímulo ar), não há vestígios do agente dessensibilizante. As setas indicam imagens sugestivas de réplica das gotas de fluido dentinário.

Figura 11C: Fotomicrografia eletrônica de varredura da réplica positiva da superfície dentinária no baseline, vista de topo. A resina epóxica não foi capaz de reproduzir detalhes, podendo-se notar a presença de inúmeras bolhas de diferentes tamanhos (setas).

Figura 11D: Fotomicrografia eletrônica de varredura da réplica positiva da superfície dentinária no baseline, com maior aumento e com inclinação de $50^{\circ}$, confirmando a presença de bolhas (setas).

Figura 12A: Fotomicrografia eletrônica de varredura da réplica negativa da superfície dentinária de um paciente com grau de sensibilidade inicial de 8,6 ao estímulo sonda e 4,2 ao jato de ar. Podem ser observados túbulos dentinários de maior diâmetro e em grande quantidade. Algumas imagens podem ser interpretadas como sendo túbulos dentinários fechados (setas).

Figura 12B: Fotomicrografia eletrônica de varredura da réplica negativa da mesma superfície imediatamente após a quarta aplicação do $\mathrm{Oxa}-\mathrm{Gel}^{\circledR}$, quando 0 paciente relatou significativa remissão da sensibilidade. Observa-se uma superfície onde os túbulos dentinários não estão mais totalmente visíveis. As setas indicam resquícios do agente dessensibilizante.

Figura 13A: Fotomicrografia eletrônica de varredura da réplica negativa da superfície dentinária de um paciente com grau de sensibilidade intenso ao estímulo sonda $(9,3)$ e moderado $(4,0)$ ao jato de ar no baseline. Pode-se observar uma grande quantidade de túbulos dentinários.

Figura 13B: Fotomicrografia eletrônica de varredura da réplica negativa representativa do final do tratamento com 0 agente dessensibilizante. Nota-se o mesmo padrão de imagem da figura anterior, embora o paciente tenha relatado diminuição do grau de sensibilidade para ambos os estímulos $(0,8$ para a sonda e 1,7 para o jato de ar).

Figura 14A: Fotomicrografia eletrônica de varredura da réplica negativa de uma superfície dentinária com intensa quantidade tubular, com desconforto severo aos estímulos sonda $(6,0)$ e jato de $\operatorname{ar}(5,8)$. 
Figura 14B: Fotomicrografia eletrônica de varredura da réplica negativa da mesma superfície após o tratamento com o agente dessensibilizante, quando o paciente relatou remissão total do desconforto ao estímulo sonda e considerável melhora ao estímulo jato de ar $(1,8)$. Observa-se a menor quantidade de túbulos dentinários, porém com maior diâmetro.

Figura 15A: Fotomicrografia eletrônica de varredura da réplica negativa da superfície dentinária com hipersensibilidade intensa $(7,2)$ ao estímulo sonda e extremamente intensa $(9,0)$ ao jato de ar, embora apresente áreas com total ausência de túbulos dentinários (setas brancas). As setas pretas indicam áreas de túbulos dentinários expostos com diferentes diâmetros. Nota-se a presença de uma fina trinca no espécime (seta vermelha).

Figura 15B: Fotomicrografia eletrônica de varredura da réplica negativa da superfície anterior após o tratamento com Oxa-Gel ${ }^{\circledR}$. Nenhum túbulo dentinário pode ser claramente observado, coincidindo com a remissão do desconforto relatado pelo paciente $(0,6$ à sonda e 1,5 ao jato de ar). Observa-se a presença de uma trinca no espécime (seta vermelha).

Figura 16A: Fotomicrografia eletrônica de varredura da réplica negativa de uma superfície dentinária com característica hiperestésica (intensa quantidade tubular), conforme relatado pelo paciente (grau 6,0 para a sonda e 7,8 para o jato de ar).

Figura 16B: Fotomicrografia eletrônica de varredura da réplica negativa da mesma superfície após o tratamento com o agente dessensibilizante. Nota-se que o padrão de quantidade tubular se mantém, embora o paciente tenha relatado grau de sensibilidade quase imperceptível aos estímulos sonda $(0,8)$ e jato de ar $(0,5)$.

Figura 17A: Fotomicrografia eletrônica de varredura da réplica negativa mostrando grande quantidade de túbulos dentinários, condizentes com o desconforto extremamente intenso $(9,3)$ ao estímulo sonda e moderado $(4,0)$ ao estímulos ar, conforme relatado pelo paciente .

Figura 17B: Fotomicrografia eletrônica de varredura da réplica negativa da mesma superfície após o tratamento com oxalato de potássio. Os túbulos dentinários aparecem em grande número, ainda que o paciente tenha relatado diminuição do desconforto a ambos os estímulos $(0,8$ à sonda e 1,7 ao jato de ar).

Figura 18A: Fotomicrografia eletrônica de varredura da réplica negativa característica de uma dentina hiperestésica (grau 10,0 ao estímulo sonda e 9,0 ao estímulo jato de ar), devido à grande quantidade de túbulos dentinários, embora de diâmetro reduzido. 
Figura 18B: Fotomicrografia eletrônica de varredura da réplica negativa da mesma superfície após o tratamento. Nota-se a diminuição considerável do número de túbulos dentinários, agora com diâmetros maiores, sendo relatado um desconforto leve $(5,2)$ somente ao estímulo sonda. Finas trincas estão, novamente, presentes (setas vermelhas).

Figura 19A: Fotomicrografia eletrônica de varredura da réplica negativa de uma superfície dentinária com grau de sensibilidade moderado $(4,50$ ao estímulo sonda e levemente forte $(5,8)$ ao estímulo ar. Observa-se a presença de túbulos dentinários abertos ou parcialmente abertos, com diferentes diâmetros.

Figura 19B: Fotomicrografia eletrônica de varredura da réplica negativa da mesma superfície após o período de 4 semanas sem tratamento. A imagem revela uma superfície recoberta com uma camada amorfa, não definida, a qual pode ter contribuído para a diminuição do grau de sensibilidade relatado pelo paciente no momento (2,7 à sonda e 3,6 ao jato de ar).

Figura 20A: Fotomicrografia eletrônica de varredura representativa da réplica negativa de uma superfície praticamente isenta de túbulos dentinários, com grau de sensibilidade leve $(3,6$ e 3,8) para os estímulos sonda e jato de ar, respectivamente.

Figura 20B: Fotomicrografia eletrônica de varredura da réplica negativa após o período de 4 semanas, quando o paciente relatou um sutil aumento da sensibilidade somente ao estímulo ar $(5,7)$. Pode-se observar uma grande quantidade de túbulos dentinários sobre a mesma superfície.

Figura 21A: Fotomicrografia eletrônica de varredura da réplica negativa em que observam-se poucos túbulos dentinários caracterizando a dentina com grau de sensibilidade leve $(3,5$ e 3,3$)$ para ambos os estímulos.

Figura 21B: Fotomicrografia eletrônica de varredura da réplica negativa, revelando maior quantidade de túbulos dentinários se comparado ao baseline. Houve um aumento do grau de sensibilidade ao estímulo sonda $(5,9)$ e uma mínima diminuição com relação ao jato de ar $(2,8)$. As setas vermelhas indicam trincas no espécime.

Figura 22A: Fotomicrografia eletrônica de varredura da réplica negativa em que se observam poucos túbulos dentinários apresentando, em sua maioria, grande diâmetro em sua maioria. $\mathrm{O}$ grau de sensibilidade foi classificado como leve para ambos os estímulos. 
Figura 22B: Fotomicrografia eletrônica de varredura da réplica negativa da mesma superfície após 4 semanas sem tratamento, quando o paciente relatou ausência de desconforto ao estímulo ar $(0,6)$ e quase imperceptível $(1,0)$ ao estímulo sonda, embora a superfície apresente grande quantidade de túbulos dentinários de pequeno diâmetro.

Figura 23A: Fotomicrografia eletrônica de varredura da réplica negativa na qual notam-se túbulos dentinários de diferentes diâmetros e grau de sensibilidade levemente forte $(5,7)$ somente ao estímulo sonda.

Figura 23B: Fotomicrografia eletrônica de varredura da réplica negativa da mesma superfície após 4 semanas sem tratamento. Os túbulos dentinários continuam presentes, mas agora com diâmetros similares. O desconforto ao estímulo sonda foi classificado pelo paciente como moderado $(4,3)$ ao final do período.

Figura 24A: Fotomicrografia eletrônica de varredura da réplica negativa de uma superfície dentinária com grau de sensibilidade classificado como intenso $(7,8)$ ao estímulo sonda e quase imperceptível $(1,7)$ ao estímulo jato de ar no baseline. Nota-se a grande quantidade de túbulos dentinários.

Figura 24B: Fotomicrografia eletrônica de varredura da réplica negativa, com diminuição considerável do grau de sensibilidade $(3,7$ para a sonda e 1,3 para o jato de ar), coincidente com a diminuição na quantidade e no diâmetro dos túbulos dentinários ao final de 4 semanas. As setas brancas indicam a presença de partículas, que podem ter contribuído para essa diminuição da sensibilidade. Essas partículas, quando não removidas durante o procedimento de moldagem, causaram defeito na superfície do molde, indicado pela seta preta.

Figura 25A: Fotomicrografia eletrônica de varredura da réplica negativa de uma superfície dentinária com grande quantidade de túbulos dentinários, sendo relatado pelo paciente grau de sensibilidade intenso $(7,0)$ à sonda e leve $(3,4)$ ao jato de ar.

Figura 25B: Fotomicrografia eletrônica de varredura da réplica negativa da mesma superfície após o período de 4 semanas, quando o paciente relatou uma leve diminuição no desconforto para ambos os estímulos, grau de sensibilidade levemente forte $(5,8)$ à sonda e muito leve $(2,3)$ ao jato de ar, coincidente com a diminuição da quantidade dos túbulos dentinários. 


\section{Avaliação da Técnica de Réplica para Análise In vitro e In vivo das Alterações da Superfície da Dentina Hiperestésica e Tratada com Oxalato De Potássio}

O presente trabalho teve como objetivo avaliar in vitro e in vivo, através de uma técnica de réplica associada à microscopia eletrônica de varredura (MEV), as características e modificações da superfície da dentina hiperestésica e tratada com um agente dessensibilizante à base de oxalato de potássio. $\mathrm{O}$ estudo in vitro foi realizado utilizando-se discos de dentina, cuja superfície foi condicionada com ácido cítrico a 6\%, coberta com smear layer artificial e dividida em 4 quadrantes. A smear layer foi mantida no quadrante 1, considerado o controle para a dentina não exposta. Os quadrantes 2, 3 e 4 de cada disco foram recondicionados com ácido cítrico a 6\%, e o oxalato de potássio foi aplicado nos quadrantes 3 e 4 . O quadrante 4 foi, então, novamente condicionado com ácido cítrico a 6\%. Feita a moldagem com Aquasil ULV, removeu-se o disco do molde após 6 minutos. Decorridas 24 horas, uma resina epóxica de baixa viscosidade foi vazada sobre o molde, e deixada polimerizar por outras 24 horas. Os discos de dentina, moldes e réplicas de resina epóxica foram metalizados para análise no MEV. No estudo in vivo, os pacientes, cujos dentes caninos e pré-molares apresentavam lesões cervicais não cariosas e sensíveis aos estímulos sonda e/ou jato de ar conforme a Escala Visual Analógica (EVA), foram selecionados e divididos em 2 grupos. No baseline, após o registro da sensibilidade em ambos os grupos, a superfície de dentina foi limpa com hipoclorito de sódio a $1 \%$, e 3 moldagens consecutivas foram realizadas, sendo a primeira para remoção de debris, e as outras, para obtenção das réplicas positivas e negativas. Os moldes foram armazenados por um período de 24 horas em local fechado, seco e limpo, e a 
resina epóxica foi, então, vazada. O Grupo 1 (16 dentes) recebeu 4 aplicações de Oxa-Gel ${ }^{\circledR}$ em intervalos de 7 dias. No Grupo 2 (7 dentes), nenhum agente antihiperestésico foi aplicado. Após 4 semanas, reavaliou-se o grau de sensibilidade, seguindo-se os mesmos procedimentos de moldagem e obtenção das réplicas, exceto a primeira moldagem. Todos os espécimes foram metalizados para análise no MEV. No estudo in vitro, a comparação das fotomicrografias dos discos de dentina e seus respectivos moldes e réplicas mostrou que essa técnica pode reproduzir as características da superfície dentinária tratada com oxalato de potássio. No estudo in vivo, as réplicas positivas não forneceram detalhes como no estudo in vitro. Por outro lado, as réplicas negativas favoreceram a análise das características da superfície da dentina hiperestésica, do efeito do oxalato de potássio, e das modificações que ocorreram na superfície dentinária no Grupo 2. A análise das fotomicrografias possibilitou o estabelecimento de uma correlação entre a presença de túbulos dentinários e o grau de sensibilidade relatado pelos pacientes nas diferentes situações. Os resultados demonstraram que a técnica de réplica negativa pode ser um recurso complementar confiável para a avaliação clínica da hiperestesia dentinária. 


\section{INTRODUÇÃO}

A hiperestesia dentinária pode ser definida como sendo uma resposta exagerada ou uma dor passageira relacionada à exposição da dentina a estímulos químicos, tácteis, térmicos ou osmóticos provenientes do meio bucal, os quais, normalmente, não causariam resposta em um dente saudável ${ }^{83,109}$. Essa exposição pode ser resultante da perda de esmalte por processos de abfração, erosão ou abrasão e, também, por desnudamento da superfície radicular por recessão gengival ou tratamento periodontal. A hiperestesia dentinária pode ocorrer em qualquer dente; porém, a maioria dos estudos aponta caninos e prémolares como os mais comuns e, quase que invariavelmente, na sua face vestibular $^{83}$.

Dentre as várias teorias que se propõem a explicar o mecanismo da hiperestesia dentinária, a Teoria da Hidrodinâmica é a mais aceita. Segundo essa teoria, introduzida por BRÄNNSTRÖM ${ }^{15}$, em 1966, o movimento do fluido no interior dos túbulos dentinários provoca a sensibilidade em decorrência da ativação sensorial de fibras nervosas presentes na polpa.

A busca de alternativas para aliviar a dor aguda causada pela dentina exposta tem sido tema de estudos que apresentam várias formas de tratamento, o que leva à suposição de que nenhuma, ainda, provou ser totalmente eficiente ${ }^{100}$. Algumas vezes, pode ocorrer a dessensibilização através de um tipo de reação natural à agressão, e a dentina torna-se capaz de aumentar seu grau de mineralização. Contudo, na maioria dos casos, um tratamento é necessário.

Entre as formas de tratamento indicadas, inclui-se o uso de agentes e terapias que atuam de modos diferentes, seja por ação antiinflamatória, por despolarização das terminações nervosas, ou por efeito oclusivo dos canalículos 
dentinários. Conforme os princípios da Teoria da Hidrodinâmica, os agentes mais utilizados no tratamento da hiperestesia são aqueles que envolvem o mecanismo hidrodinâmico da dentina e, desse modo, atuam sobre a condutibilidade da mesma.

O objetivo clínico do tratamento da hiperestesia dentinária é promover o selamento dos túbulos dentinários. Os agentes que obliteram os canalículos dentinários podem atuar por meio de precipitação de proteínas, pela deposição de cristais nos túbulos dentinários ou por técnicas restauradoras convencionais ${ }^{100}$.

O oxalato de potássio age tanto pela obliteração dos túbulos dentinários, através da formação de cristais de oxalato de cálcio na superfície e no interior dos túbulos, como também pela despolarização das terminações nervosas devido à atuação do potássio ${ }^{82}$. Um selamento pode ser conseguido por aplicação tópica de oxalatos na forma de precipitados insolúveis, o que reduz a condutibilidade hidráulica da dentina ${ }^{47}$. Tal ocorrência deve-se, provavelmente, à deposição de cristais de oxalato de cálcio dentro dos túbulos, controlando, assim, a sensibilidade da dentina exposta. Esse tipo de tratamento tem sido relatado por muitos autores, que têm utilizado o oxalato de potássio em diferentes concentrações.

O mecanismo da dor dentinária ainda não é bem compreendido, e os sinais e sintomas da hiperestesia são inespecíficos e subjetivos. Por outro lado, embora uma grande variedade de produtos tenha sido testada, os resultados de sua aplicação são, na maioria das vezes, contraditórios. Além disso, é preciso considerar o efeito placebo, freqüentemente reconhecido como muito significativo nas investigações clínicas ${ }^{32,74,75,84}$.

A técnica de réplica, associada à microscopia eletrônica de varredura (MEV), tem sido amplamente utilizada para estudos in vitro e in vivo da superfície 
dos tecidos dentários mineralizados e suas interações com os diferentes materiais odontológicos $2,3,86,108$.

A possibilidade de observar-se, através da técnica da réplica, as características da dentina hiperestésica e prováveis alterações na sua superfície após a aplicação de um agente dessensibilizante "in vivo" pode representar uma importante complementação da avaliação clínica. É nesse sentido que o desenvolvimento do presente trabalho busca oferecer uma contribuição. 


\section{REVISÃO DA LITERATURA}

\subsection{TÉCNICA DE RÉPLICA}

\section{Definição, Nomenclatura e Princípios}

Uma réplica é definida como sendo a cópia de um original obtida através de procedimentos de reprodução ${ }^{69}$. Quando não é possível observar-se diretamente a superfície de um espécime, pode-se fazê-lo no microscópio eletrônico de varredura (MEV). Essa técnica é também indicada quando se deseja observar mudanças na superfície de um mesmo espécime e, ainda, quando procedimentos convencionais podem causar alterações inaceitáveis no espécime ${ }^{12}$.

PAMEIJER; STALLARD ${ }^{88}$ publicaram, em 1972, uma pesquisa sobre a aplicação das técnicas de réplica associadas ao microscópio eletrônico de varredura em pesquisas odontológicas. Nesse artigo, os autores relatam dois métodos citados na literatura: o primeiro, denominado "técnica de réplica quente", foi utilizado principalmente para o estudo da abrasividade de diferentes dentifrícios em superfícies de coroas veneer de acrílico; o segundo, a chamada "técnica de réplica fria", consistiu na obtenção de um modelo de resina epóxica a partir de uma moldagem obtida in vivo. Com o propósito de observar tecidos duros dentais, os autores propuseram a utilização de uma fita de acetato umedecida com acetona e colocada, sob uma leve pressão, no lado em contato com a superfície a ser copiada. Após o endurecimento dessa fita, a mesma foi retirada do espécime e descartada, pois essa primeira moldagem teve como finalidade apenas remover partículas. Realizada a segunda moldagem, que foi preparada para observação direta no MEV, os autores obtiveram uma reprodução negativa do original. Como uma segunda alternativa, fez-se a aplicação de uma 
silicona (Silflo - Flexico Developments Ltd., England) sobre a fita de acetato, obtendo-se uma reprodução positiva e exata do original a ser preparada e observada no MEV.

Os mesmos autores, em outro artigo publicado em $1972^{87}$, ressaltaram que na técnica descrita acima, a qual denominaram de "técnica de réplica dura", era necessária a utilização de pressão para a obtenção de detalhes, sendo indicada para o estudo de tecidos duros in vivo e in vitro. No caso do estudo de tecidos moles, essa técnica não seria viável, pois, além do difícil acesso a determinadas regiões da cavidade oral, a pressão poderia causar distorções no tecido. Assim, propuseram que a moldagem fosse feita usando um hidrocolóide. A região a ser reproduzida foi limpa com jatos de ar, secada e isolada com roletes de algodão para evitar a contaminação com saliva. O molde foi cuidadosamente removido e preenchido com silicona (Silflo). Após o endurecimento, o mesmo foi separado e preparado para metalização. Essa técnica, indicada para a observação de tecidos moles e de placa dental, evita a destruição do tecido, e é utilizada em estudos longitudinais.

SCHOEN et al. ${ }^{111}$, em 1978, relacionaram os critérios básicos para o desenvolvimento de uma técnica de réplica simples e acessível:

1. deve ser atraumática e não tóxica para os tecidos a serem replicados;

2. deve ser exata e precisa na reprodução de detalhes;

3. o material de réplica deve polimerizar em curto período de tempo;

4. a remoção da réplica deve ser fácil e não causar distorção;

5. a réplica não deve sofrer alterações quanto submetida ao procedimento de metalização necessário para observação no MEV;

6. a observação sob vácuo não deve alterar a réplica; 
7. a réplica deve proporcionar um campo positivo semelhante ao original, bem como proporcionar uma reprodução negativa que possibilite uma fácil interpretação.

Os autores citam, ainda, que o uso de réplicas evita a contração e o surgimento de artefatos associados ao preparo de amostras biológicas para 0 MEV e, como a técnica de réplica não modifica as estruturas que estão sendo avaliadas, pode ser utilizada várias vezes em intervalos pré-determinados.

Em 1978, BARNES ${ }^{6}$, em um primeiro artigo de revisão, relatou que, embora os princípios da técnica de réplica estivessem bem entendidos, o sistema de nomenclatura ainda precisava ser esclarecido. Essa divergência parece ser proveniente da técnica de réplica utilizada para microscopia eletrônica de transmissão, na qual a observação é feita através do molde, resultando, assim, na imagem positiva do substrato. Nesse caso, o molde pode ser denominado "réplica". O MEV possibilita a observação sobre, e não através do molde. Já que esse molde representa uma imagem negativa do substrato, não pode ser denominado réplica, e sim "primeiro molde", pois será examinado diretamente no MEV ou utilizado na fase preliminar da obtenção de réplica de resina. O termo "réplica negativa" refere-se ao modo de obtenção do modelo, ou seja, o material fluido é aplicado dentro do primeiro molde, em seguida removido e observado no MEV. Essa amostra é uma cópia fiel do substrato, daí a denominação correta: réplica.

BARNES $^{7}$, em 1979, em continuação ao artigo publicado em 1978, ressaltou a interpretação dos procedimentos de réplica in vivo e in vitro. Segundo autor, em ambos os tipos de estudo, a superfície dentinária deve ser limpa antes de realizar-se a primeira moldagem, o que pode ser feito por meio de secagem superficial com jato de ar e aplicação de material de moldagem, cuja remoção 
promove a retirada das impurezas mais grosseiras presentes na superfície. Para moldagem in vivo, o autor sugere a confecção de moldeiras individuais.

Quanto à interpretação das réplicas, a presença de artefatos é muito comum e, quando não reconhecidos, podem causar erro na leitura. Os artefatos mais comumente encontrados vêm enumerados a seguir:

1. Perda de detalhes superficiais, cujas causas podem ser:

a) falhas durante a moldagem devido a erro de proporção e/ou espatulação do material; parte do material estar polimerizado no momento da moldagem; e, ainda, por falta de pressão de moldagem quando o material é utilizado em duas consistências;

b) polimerização incompleta da resina utilizada para a obtenção das réplicas positivas, possivelmente por uso de resina fora do prazo de validade.

c) fratura da réplica, embora incomum, possivelmente devida ao proporcionamento incorreto e não utilização do agente plastificador;

d) contaminação por líquidos quando a dentina é cortada, pois o fluido proveniente dos túbulos dentinários pode interferir na polimerização da silicona, o que é replicado na resina. Quando o material de moldagem apresenta polimerização lenta ou o substrato é úmido, a camada do líquido replicado pode impedir a visualização de detalhes superficiais. Essa camada pode ser distinguida por uma superfície elevada e de contorno liso.

2. Ruptura do material de moldagem, que pode ocorrer principalmente quando se avalia a interface ou a fenda formada entre um material restaurador e a estrutura dentária. O material de moldagem penetra nessa falha, podendo romper-se durante a remoção da superfície dentária ou durante o procedimento de separação da resina, o que resulta em erro na interpretação. 
3. Bolhas de ar são mais comuns quando se utiliza um material de moldagem viscoso, e sua presença na réplica de resina causa muitas lacunas na superfície da mesma. Tais bolhas são raramente vistas devido à baixa viscosidade das resinas epóxicas.

Segundo o autor, é possível obter-se réplica de gotículas de fluidos. Quando um material de moldagem tem viscosidade, o tamanho e o número de gotículas replicadas são quase sempre proporcionais à umidade do substrato e ao tempo de polimerização do material de moldagem. No caso de dentina exposta, o autor sugere a utilização da resina Scutan como material de moldagem.

BOZZOLA; RUSSELL ${ }^{12}$, em 1999, apontam duas técnicas: réplica negativa e réplica positiva. Uma das técnicas de réplica negativa consiste na aplicação de um filme de acetato de celulose, o qual endurece após a evaporação da acetona. Como a acetona é aplicada sobre a superfície a ser replicada, esse procedimento está indicado para superfícies duras e não vitais, as quais não sofreriam alteração com a aplicação desse solvente. Segundo os autores, é uma técnica simples, porém limitada, pois apresenta baixa capacidade de reprodução e é útil apenas para grandes aumentos.

Outra técnica citada pelos autores é a técnica de réplica negativa/positiva utilizando-se silicona e resina. Essa técnica é considerada superior à anterior, pois espécimes vivos com maior topografia podem ser observados com melhor resolução. Embora seja mais complicada, a técnica de réplica negativa/positiva requer diferentes tipos de materiais considerados tóxicos como, por exemplo, a resina epóxica.

Seguindo-se esse procedimento, primeiro faz-se uma réplica negativa do substrato utilizando um material de moldagem tipo silicona ou polivinilsiloxano; o molde obtido posteriormente é preenchido com um monômero plástico, no caso a 
resina epóxica, resultando, assim, a réplica positiva. A seqüência para obtenção de réplicas por meio dessa técnica é descrita detalhadamente a seguir:

- posicionar firmemente o espécime a ser replicado;

- proporcionar e misturar o material de moldagem seguindo as recomendações do fabricante;

- limpar a superfície esfregando-se um tecido que não solte fiapos, embebido em solução tampão e, depois, em etanol a 70\%, se possível, para remover debris e oleosidade;

- aplicar rapidamente o material de moldagem sobre a superfície antes que ocorra a polimerização da silicona; em seguida, com um leve jato de ar, espalhar o material sobre a superfície e aguardar o tempo de polimerização;

- colocar uma outra camada de silicona a fim de dar suporte ao molde e removê-lo;

- observar a réplica no microscópio para avaliação de possível presença de bolhas de ar ou outras irregularidades; repetir o procedimento se necessário.

- se for preciso observar a réplica negativa, montá-la em um stub e metalizá-la. Com relação à observação da réplica positiva, preparar a resina epóxica de baixa viscosidade ou algum material à base de acrílico;

- verter a resina no molde, evitando a formação de bolhas de ar. Se necessário, utilizar uma câmara de vácuo;

- aguardar a polimerização da resina em estufa a $60^{\circ}$ durante uma noite;

- separar a silicona da réplica positiva;

- montar a réplica em um stub

- metalizá-la e observá-la no MEV. 


\section{Aplicações da Técnica de Réplica em Odontologia}

A técnica de réplica, associada à microscopia eletrônica de varredura, tem aplicação em diferentes campos de estudo, e sua utilização em pesquisas odontológicas vem de longa data. A literatura nessa área compreende inúmeras pesquisas que apresentam variados materiais e técnicas de réplica realizadas in vivo para a obtenção de maiores conhecimentos sobre os tecidos moles e duros da cavidade oral. É no sentido de ressaltar tais estudos que se apresenta, a seguir, uma revisão da literatura pertinente ao assunto de que trata esse trabalho.

GEROULD ${ }^{40}$, já em 1944, observou, no microscópio eletrônico de transmissão, a microestrutura de dentes humanos utilizando réplicas de sílica e poliestireno. A superfície a ser observada foi moldada com polietireno aquecido a $160^{\circ} \mathrm{C}$ e pressão de aproximadamente 3000 libras/polegadas. As moldagens foram, então, separadas dos espécimes, e o original foi dissolvido em ácido. A sílica, evaporada sobre o polietireno para formar uma película de aproximadamente 0,02 microns, foi removida com solvente para observação no microscópio eletrônico de transmissão. Réplicas de dentes extraídos foram preparadas para comparação. Apesar da dificuldade em reconhecer e comparar as mesmas áreas no microscópio, o autor concluiu que essa técnica era bastante viável, pois permitiu uma comparação quantitativa e qualitativa, o que veio a favorecer sua utilização em pesquisas odontológicas.

SCOTT; WYCKOFF ${ }^{112}$, em 1949, apresentaram um relato das limitações do estudo da superfície dentária naquela época, quando a observação das estruturas de esmalte e do processo de cárie era realizada em cortes perpendiculares descalcificados da superfície dentária, bem como o pouco 
conhecimento de que se dispunha, até então, sobre a microestrutura e propriedades da superfície de esmalte. Métodos de seccionamento não poderiam ser utilizados devido à curvatura da superfície dentária e à dificuldade em examinar detalhes dessas partes seccionadas utilizando-se luz transmitida. Segundo os autores, a técnica de réplica tornou possível a observação da estrutura das superfícies dentárias e da natureza do processo destrutivo envolvido na doença cárie. Essa técnica pode ser aplicada também para o estudo do efeito de agentes químicos, dentifrícios e abrasivos sobre a estrutura dentária. Nesse estudo, os autores observaram os estágios progressivos da perda de detalhes estruturais da superfície de dentes in vivo. As réplicas foram obtidas utilizando-se uma película de celoidina aplicada sobre a superfície dentária através de uma fita plástica adesiva; e a superfície desse molde foi iluminada obliquamente para observação no microscópio eletrônico convencional.

Essa técnica de réplica resulta em finas películas de celoidina que são imagens negativas perfeitas de finos detalhes do espécime, mas que perdem completamente a definição do contorno e de detalhes topográficos da superfície da amostra. Por outro lado, o MEV apresenta uma capacidade única de profundidade de foco, de produção de imagens das características topográficas da superfície de qualquer espécime, ou seja, proporciona a visualização de imagens tridimensionais. A réplica ideal para exame no MEV deve apresentar não só uma reprodução exata de finos detalhes, tal qual no método clássico de réplica obtidas por películas, como também sua forma tridimensional.

As réplicas tridimensionais podem ser obtidas utilizando-se materiais de moldagem $^{5}$, como descrevem os autores a seguir.

FACQ; VOLPE ${ }^{35}$, em 1970, desenvolveram uma técnica que permitiu observar, in vivo, detalhes microscópicos da abrasividade de três dentifrícios na 
superfície de próteses fixas de acrílico. Para tanto, adaptaram uma técnica utilizada para o estudo de tecidos moles, mais especificamente da pele humana, a fim de replicar tecidos duros, como a superfície dentária ou a resina acrílica. A técnica de réplica utilizada consistiu de duas fases: na primeira, fez-se uma moldagem in vivo da superfície de acrílico usando-se silicona (Silflo Silicona Impression Material, J\&S Davis Ltd., London); na segunda fase, as moldagens foram preenchidas com resina Versalon 1112, obtendo-se, assim, as réplicas. Os resultados indicaram que a réplica associada à microscopia eletrônica de varredura pareceu ser um procedimento útil para avaliação in vivo da abrasividade de dentifrícios.

GRUNDY ${ }^{50}$, em 1971, sugeriu uma técnica de réplica com o objetivo de avaliar in vivo a superfície de dentes e de restaurações. Conforme o autor, a utilização de silicona (elastômero) tem como desvantagem o seu alto coeficiente de expansão térmica. A réplica de silicona a ser observada no microscópio eletrônico deve receber uma cobertura de metal, o que poderia causar fratura e decomposição como resultado das mudanças de temperatura durante 0 procedimento de metalização. Esse problema pode ser contornado pela obtenção de uma réplica positiva com um material dimensionalmente estável. Uma vantagem em utilizar-se essa técnica de dois estágios é que a interpretação da imagem da réplica positiva torna-se mais fácil do que a interpretação do negativo, ou seja, do próprio molde. Assim, o autor utilizou a técnica de réplica em dois estágios: no primeiro, as superfícies foram limpas com bastonetes de algodão úmidos, lavadas com água atomizada e secadas com ar morno. Uma moldagem preliminar foi feita para remover debris da superfície e, depois, descartada. A superfície foi mantida seca com isolamento relativo e sugador, e a moldagem foi 
realizada com elastômero com auxílio de uma espátula metálica. O adesivo do material foi passado, antes da colocação do elastômero, sobre um rebite de alumínio o qual serviu como uma mini-moldeira, e levado em posição, sob leve pressão e vibração, para moldar a superfície. Após 3 ou 4 minutos, o molde foi removido. No segundo estágio, a resina Araldite, selecionada por reproduzir detalhes e também por ser estável o suficiente na prevenção de fraturas durante a metalização, foi vertida sobre esse molde. Após o período de endurecimento (24 horas) à temperatura ambiente, a resina foi separada do molde, obtendo-se as réplicas positivas. As amostras foram coladas em stubs, metalizadas e observadas no MEV. A qualidade de reprodução obtida nas fotomicrografias mostrou que essa técnica, utilizada para estudo intra-oral das superfícies dos dentes e de restaurações, pode ser perfeitamente aplicada quando uma avaliação qualitativa é necessária.

BARNES $^{5}$, em 1972, apresentou uma nova técnica de moldagem para obtenção de réplicas para utilização no MEV, e comparou-a com a técnica de moldagem com silicona. O material de moldagem sugerido era uma solução a $2 \%$ de Formvar (formol polivinil) em clorofórmio, e uma borracha à base de tiocol foi utilizada para comparação. No grupo controle, foram usadas duas viscosidades do material de moldagem, sendo uma silicona de consistência pesada (Sylflex) e outra de baixa viscosidade (Sylflo). A silicona foi colocada sobre a superfície a ser copiada e deixada a polimerizar sem pressão ou distorção; depois, foi removida com outra camada de material de moldagem colocado em uma mini-moldeira feita com anel de cobre e coberta com um adesivo apropriado. No segundo estágio, a área a ser examinada foi delimitada com cera, e a resina Araldite (Ciba) foi proporcionada e vertida sobre o molde. No grupo experimental, uma película foi 
obtida a partir da moldagem com a mistura de Formav com clorofórmio, e o molde poderia ser base para obtenção de réplicas ou ser metalizado e observado diretamente no MEV. Os resultados mostraram que as indicações para aplicar-se essa técnica ou aquela de moldagem com silicona depende da natureza do espécime a ser reproduzido. Para observação de margens de restaurações, a silicona pode ser utilizada e, nesse caso, a de consistência mais fluida (Sylflo) apresentou uma melhor qualidade de moldagem, o que não foi observado nos moldes feitos com a silicona pesada (Sylflex). Nos casos em que a reprodução de detalhes for necessária, a técnica usando película de Formar é mais indicada. A desvantagem, porém, é que o tempo de 25 minutos necessários para que ocorra a polimerização desse produto torna inviável a utilização dessa técnica in vivo.

DESPAIN; LLOYD; BROWN²8, em 1974, avaliaram a utilização da técnica de réplica para observar microscopicamente, in vitro e in vivo, trincas nos dentes submetidos a cargas mecânicas ou térmicas. As moldagens foram feitas com silicona de condensação (Xantopren), e as réplicas obtidas com resina epóxica de baixa viscosidade (Tooling, Hysol). Após o endurecimento, as réplicas foram removidas do molde, metalizadas e observadas no MEV. As réplicas dos dentes extraídos foram obtidas antes e depois de os dentes serem submetidos às variações térmicas a fim de avaliar seu efeito nas trincas, as quais foram comparadas àquelas presentes nas réplicas dos dentes in vivo. Os autores concluíram que a formação de trincas pode ser induzida por variações térmicas, cargas ou ambas. Concluíram, ainda, que a técnica de réplica para MEV pode ser um procedimento viável na pesquisa de materiais que estariam sujeitos a danos causados pelos procedimentos preparatórios para microscopia. De acordo com os autores, o uso dessa técnica pode ser estendido ao estudo da formação dentária, 
das modificações nas margens de restaurações e, também, da formação de cálculo e placa bacteriana.

KUSY; LEINFELDER ${ }^{67}$, em 1977, avaliaram 14 produtos (8 siliconas, 2 polissulfetos, 1 poliéter, 2 siliconas cirúrgicas e 1 acetato de celulose) quanto à sua capacidade de moldagem e obtenção de réplicas. Estudaram, ainda, a eficácia de uma técnica de réplica de um estágio para avaliação da superfície de restaurações. Os dentes a serem replicados foram restaurados com resina, embebidos em resina acrílica formando blocos e, depois, seccionados e polidos. Inicialmente, a superfície de cada molde foi observada e fotografada com aumento de 40X a fim de avaliar a resolução de detalhes e a presença de artefatos. As moldagens com melhor resolução e sem artefatos foram metalizadas e observadas no MEV. Os resultados demonstraram que as siliconas Xantopren Blue e Silene apresentaram as melhores propriedades de fluidez e polimerização, determinando profundidade na reprodução e grau de resolução de detalhes, requisitos necessários para réplica in vivo. A técnica de réplica de um estágio, ou técnica de réplica negativa, mostrou-se viável para observação do desgaste superficial de restaurações. Entre as vantagens dessa técnica estão o menor número de etapas envolvidas, redução de artefatos e do tempo na preparação do espécime.

Em 1978, SCHOEN et al. ${ }^{111}$ compararam 22 materiais entre si, incluindo 19 elastômeros odontológicos, quanto à capacidade de replicar os detalhes de uma superfície padronizada. Os resultados demonstraram que a fita de acetato de celulose reproduziu melhor os detalhes finos e, por essa razão, é tão utilizada em microscopia eletrônica de transmissão. Os autores obtiveram resultados variados 
entre os materiais de moldagem: os polissulfetos, poliéteres e siliconas tiveram performances relativamente boas. De modo geral, a habilidade de réplica está inversamente relacionada às características de fluidez dos materiais, ou seja, os denominados materiais pesados demonstraram uma reprodução melhor quando comparados aos materiais mais fluidos. Esse resultado curioso, e ainda não explicado, pode ser devido ao tamanho da carga utilizada nos diferentes elastômeros ou ao mecanismo de fluidez no interior de pequenos espaços.

COWELL; SAXTON ${ }^{25}$, em 1978, compararam um polímero não elastomérico (Scutan, Kerr) com a silicona Silflo a fim de mensurar o índice de desgaste em lesões de abrasão in vivo. Esse polímero, desenvolvido para confecção de coroas e pontes provisórias, foi escolhido por não apresentar distorções a olho nu. Superfícies de vidro foram moldadas sem compressão e sem moldeiras, apenas com leve jato de ar. Após um período de 20 minutos, o molde foi removido. Repetiu-se o mesmo procedimento com a silicona Silflo. No estudo in vitro, a remoção do molde com Scutan foi muito difícil, o que não ocorreu in vivo. Como os moldes de Silflo não podem ser observados no MEV, obtiveram-se réplicas positivas com resina epóxica (Araldite), o que também foi feito para os moldes de Scutan. Os resultados apontaram um desempenho satisfatório de Scutan, o qual pode ser utilizado na obtenção de réplicas de lesões cervicais de abrasão in vivo.

Em 1981, LAMBRECHTS; VANHERLE; DAVIDSON ${ }^{69}$ desenvolveram uma técnica de réplica universal a partir da modificação da técnica de recobrimento da superfície com cobre. Para comprovar a eficácia da técnica, tecidos orais e restaurações foram moldados em diferentes estágios. A fim de remover placa, 
película adquirida e remanescentes orgânicos, a superfície a ser moldada foi limpa com bastonetes de algodão embebidos em hipoclorito de sódio e água oxigenada, seguindo-se a lavagem com água e secagem com jatos de ar. A moldagem da superfície foi realizada com uma silicona leve (President, Coltene), a qual foi injetada sobre a superfície e acomodada com leves jatos de ar. Uma moldeira de acrílico especial com material de moldagem foi, então, acomodada sobre o dente. Após a retirada do molde, o mesmo foi limpo com álcool para remoção de sangue, saliva ou partículas presentes na superfície, e secada com jatos de ar. Um modelo positivo foi obtido por eletrodeposição de cobre para visualização no MEV, cujas imagens revelaram a possibilidade de reprodução dos detalhes superficiais.

LAMBRECHTS; VAN STEENBERGHE; VANHERLE ${ }^{68}$, em 1982, utilizaram a técnica de réplica com o objetivo de observar a micromorfologia de tecidos moles e depósitos sobre os dentes in vivo. Foram realizadas três réplicas de placa maturada em pacientes adultos com higiene oral deficiente. Antes da moldagem, a superfície recebeu um leve jato de spray ar-água, seguido de secagem, e o isolamento relativo foi realizado. O material de moldagem de baixa viscosidade (President, Coltene) foi levado com uma moldeira sobre a superfície com leve pressão de jato de ar. Obteve-se a réplica positiva por eletrodeposição de cobre, sendo gesso pedra vertido posteriormente. As amostras foram observadas no MEV, e os resultados mostraram que essa nova técnica possibilitou diferenciar mudanças sutis nos detalhes superficiais.

Em 1984, HIRVONEN; NÄRHI; HAKUMÄKI ${ }^{54}$ avaliaram o efeito do condicionamento ácido, do tratamento com oxalato de potássio e da impregnação 
de resina na resposta neural da dentina estimulada. As características da abertura dos túbulos dentinários após os diferentes tratamentos foi avaliada por meio da técnica de réplica e do MEV. Foram utilizados dentes permanentes de 12 cães, os quais foram anestesiados. Estando o canal mandibular esquerdo exposto, o nervo pulpar foi identificado através de estímulo elétrico e monitorado por um osciloscópio. O esmalte incisal foi removido com broca em alta rotação, e a dentina exposta sofreu estímulos com jatos de ar e sonda clínica, sendo a resposta monitorada. O condicionamento da superfície com ácido fosfórico a 37\% foi feito por um período de 10 segundos, seguido da aplicação de oxalato de potássio a $30 \%$ e de um adesivo (Concise Enamel Bond), procedimentos que foram repetidos inúmeras vezes durante o experimento. As superfícies tratadas foram moldadas com silicona de baixa viscosidade (Xantopren Light Body) com anéis de cobre, obtendo-se as réplicas positivas com resina epóxica (Spurr Epon). Os espécimes foram metalizados e observados no MEV. Os resultados demonstraram que, tanto nas réplicas quanto nos espécimes originais, existe uma relação entre a abertura dos túbulos e a sensibilidade dentinária, pois, quando os túbulos estavam parcial ou totalmente obstruídos, nenhuma resposta neural foi observada.

VOSSEN et al. ${ }^{122}$, em1985, descreveram uma técnica de réplica associada ao MEV a fim de avaliar in vivo as mudanças superficiais de restaurações de resina composta. Três materiais de moldagem foram testados: uma borracha à base de polisulfeto (Omniflex, Coe Laboratories), um poliéter (Impregum, ESPE) e uma silicona (Xantopren Blue, Bayer Dental). Para as réplicas, foram testadas três resinas epóxicas: Epon 812 (Merck), Spurr's e Stycast 1266 (Emerson \& Cuming). Após a metalização, as réplicas positivas e negativas foram observadas e 
comparadas no MEV. A melhor combinação foi novamente testada in vitro, utilizando-se uma superfície áspera preparada com resina e carborundum, bem como a superfície de esmalte de dentes naturais extraídos. Antes, porém, da moldagem desse esmalte, a superfície foi limpa com hipoclorito de sódio a 30\%, lavada com água e secada com jato de ar. Realizaram-se moldagens da superfície de esmalte tratada com flúor a $70 \%$ por 5 min. Por fim, a melhor combinação foi aplicada in vivo, obtendo-se réplicas positivas e negativas de restaurações Classe II realizadas com 4 diferentes materiais restauradores. Uma moldagem inicial, feita com Optosil, serviu de base para a realizada com Xantopren Blue. Nessa fase, foram testadas 3 diferentes maneiras de realizar-se a limpeza da superfície a ser moldada: 1) aplicação do Xantopren Blue; 2) limpeza com peróxido de hidrogênio a 3\%, lavagem com água e secagem com ar; e 3) limpeza com hipoclorito de sódio a 3\%, lavagem com água e secagem com ar. 0 Xantopren Blue foi removido após 5 minutos, e as réplicas negativas armazenadas. Após 24 horas, as réplicas positivas foram confeccionadas, metalizadas e observadas no MEV. Os autores concluíram que a combinação Xantopren Blue / Stycast resultou em grande precisão de detalhes. Quanto à limpeza da superfície, a utilização de uma moldagem prévia com Xantopren Blue consome muito tempo numa situação clínica, enquanto que a realizada com hipoclorito mostrou-se a mais eficiente por ser rápida e menos irritante.

Em 1989, YOSHIYAMA et al. ${ }^{133}$, propuseram a utilização de uma técnica de biópsia para investigar in vivo as mudanças estruturais nos túbulos dentinários em áreas sensíveis e não sensíveis de lesões em forma de cunha. Foram selecionados 18 adultos com lesões de abfração hiperestésicas, diagnosticadas por estímulos táctil (sonda exploradora), térmico (água gelada a $20^{\circ} \mathrm{C}$ por 5 
segundos) e evaporativo (jato de ar por 5 segundos), totalizando 22 dentes, os quais seriam restaurados. A biópsia da dentina exposta foi realizada após anestesia local e isolamento absoluto. A superfície foi limpa com água oxigenada a 3\%, lavada e secada com jato de ar. Os espécimes cilíndricos de dentina sensível e não sensível, com diâmetro aproximado de $0.8 \mathrm{~mm}$ cada, foram obtidos com ponta diamantada cilíndrica em alta rotação, sendo dois espécimes por dente. Dos 22 pares obtidos, 14 foram analisados no MEV e 8 foram submetidos a microradiografia. As lesões foram, então, restauradas com cimento de ionômero de vidro, e os pacientes foram reexaminados após 1 mês e 3 meses. Os resultados obtidos na microscopia revelaram que as áreas de dentina sensíveis apresentaram maior porcentagem de túbulos dentinários abertos. Por outro lado, nas áreas não sensíveis, os túbulos dentinários encontravam-se obstruídos, e a superfície extremamente lisa.

WALSH; BASU ${ }^{125}$, em 1987, avaliaram duas técnicas de réplica comumente utilizadas para microscopia eletrônica de varredura com o objetivo de identificar as deficiências inerentes a essas técnicas, quantificar as mudanças dimensionais e angulares que poderiam ocorrer, e selecionar a técnica mais apropriada para o estudo da topografia superficial da mucosa do palato. Para tanto, foram realizados estudos laboratoriais em animais e em humanos. Após a lavagem e secagem da mucosa, a moldagem foi feita com silicona de adição (Reprosil, DeTrey AG), e as réplicas foram obtidas com resina epóxica (Araldite). Nos testes com animais, foi realizada a biópsia da área para fins de comparação. As observações no MEV mostraram que as réplicas epóxicas obtidas nos testes laboratoriais eram muito semelhantes aos originais, notando-se a presença de alguns artefatos, como a inclusão de ar no molde ou na réplica. Nos estudos 
efetuados em animais, a réplica apresentou baixa definição, ao contrário do que ocorreu nas réplicas da mucosa humana, em se pode observar a presença de ductos salivares e até algumas colônias de bactérias, dependendo do aumento utilizado. Segundo os autores, essa técnica pode substituir o método invasivo que caracteriza a biópsia.

Uma técnica simples foi empregada por WAKABAYASHI et al. ${ }^{123}$, em 1988, a fim de replicar as paredes dentinárias da câmara pulpar de dentes extraídos. Foram utilizados 50 terceiros molares hígidos, cuja câmara pulpar foi exposta. Após permanecerem submersos em hipoclorito de sódio a 10\% por 72 horas para possibilitar a remoção de tecidos pulpares e pré-dentina, uma resina sintética de baixa viscosidade (Mercox) foi injetada no interior da câmara pulpar. Após a polimerização, os dentes foram mantidos em ácido cítrico para dissolver os tecidos calcificados e obter as réplicas. Um outro grupo de dentes foi preparado para observação direta no MEV e comparação com as réplicas. Os autores concluíram que a resina sintética é um excelente material para obtenção de réplicas de tecidos dentários mineralizados.

ABSY; ADDY; ADAMS $^{2}$, em 1989, realizaram um estudo cujo objetivo foi desenvolver e avaliar uma técnica de réplica que pudesse ser aplicada in vivo, ou seja, no estudo clínico da dentina cervical sensível e não sensível sem que dentes fossem extraídos. Além disso, a técnica poderia ser utilizada para avaliar agentes terapêuticos e, ainda, determinar o efeito mediato dos mesmos na obliteração dos túbulos dentinários. Com o propósito de permitir uma comparação direta entre o original e as réplicas, um estudo preliminar foi realizado in vitro. Dezoito dentes uniradiculares hígidos e recém-extraídos tiveram a região radicular, abaixo da 
junção cemento-esmalte, planificada com cureta de Gracey a fim de expor a dentina. Essa superfície foi condicionada com ácido fosfórico a 30\% por 60 segundos, lavada com solução salina isotônica e secada com jato de ar. A região cervical e a dentina condicionada foram marcadas com uma lâmina de bisturi número 11. Na moldagem, utilizou-se silicona de condensação (Xantopren Plus, Bayer), proporcionada e manipulada de acordo com as especificações do fabricante, e colocada sobre a região com auxílio de uma seringa. Após 6 minutos de polimerização, o material foi removido cuidadosamente do espécime e colocado em recipiente livre de umidade por 24 horas. As réplicas foram obtidas com resina epóxica (Skycast 1266), que foi vertida sobre o molde. Após 8 horas, a réplica e o espécime original foram metalizados e observados no $M E V$, com aumento de 1000 vezes. A marca realizada possibilitou que as mesmas áreas fossem comparadas através de fotomicrografias obtidas por dois examinadores. $O$ mesmo procedimento foi, novamente, realizado utilizando-se dentes extraídos diagnosticados como hiperestésicos e não hiperestésicos. Réplicas e originais foram, então, comparados por fotomicrografias das áreas julgadas como sendo as mais próximas possíveis da mesma área do espécime original. O estudo in vivo selecionou dentes com dentina radicular exposta e que seriam, posteriormente, extraídos. Foram realizados teste de vitalidade e radiografias a fim de evitar resultados falso-positivos. Os estímulos jatos de ar e sonda clínica foram utilizados para determinar dentes não sensíveis ou hiperestésicos. A região cervical dos dentes foi limpa com hipoclorito de sódio a 1\%, lavada e secada com jato de ar. Sob isolamento relativo, fez-se uma marca, e a superfície, moldada da mesma maneira que no estudo in vitro, foi removida com silicona pesado (Optosil), e as réplicas positivas foram preparadas. Os dentes foram extraídos e, juntamente com as réplicas, observados no MEV. Com relação aos 18 dentes 
condicionados com ácido, a qualidade da réplica foi considerada muito boa em 12 deles, boa em 4 e moderada em 2. Os túbulos com diâmetro menor que $1 \mu \mathrm{m}$ foram claramente copiados. Tanto nos dentes hipersensíveis como nos não sensíveis extraídos, os detalhes da superfície foram bem copiados e, em um dos espécimes, pode-se observar estruturas intratubulares na réplica as quais condiziam com a imagem do original. No estudo in vivo, 21 dentes foram classificados em não sensíveis (9) e hiperestésicos (12). Os túbulos ficaram aparentes tanto na réplica como no original em todos os dentes hiperestésicos. Nesse grupo, 8 réplicas foram consideradas de qualidade muito boa, 3 boas e 1 de qualidade moderada. Para os dentes não sensíveis, 2 foram muito boas, 2 boas, 2 moderadas e 1 ruim. Do mesmo modo, túbulos com diâmetro menor que $1 \mu$ foram observados nas réplicas. Os autores concluíram que a técnica de réplica pode ser utilizada tanto para diagnóstico e avaliação de agentes terapêuticos que obliteram os túbulos dentinários, como também no estudo da ação da dieta ácida na dentina e da etiologia da hiperestesia dentinária.

Em 1990, YOSHIYAMA et al. ${ }^{134}$ avaliaram, através de microscopia eletrônica de transmissão, as características da dentina radicular hipersensível e não sensível in vivo, utilizando a técnica de biópsia descrita por YOSHIYAMA et al. em 1989. As imagens da microscopia revelaram claramente que o lúmen da maioria dos túbulos se apresentava obstruído por cristais minerais nas áreas não sensíveis e, nas áreas sensíveis, os túbulos apresentaram-se vazios e circundados por dentina peritubular e intertubular.

BEVENIUS; HULTENBY ${ }^{8}$, em 1991, descreveram uma técnica com o objetivo de reproduzir a região cervical de dentes humanos para observação em 
MEV. O método, aplicado in vivo, foi avaliado em 4 pré-molares que seriam extraídos por razões ortodônticas e, para comparação, os espécimes originais também foram observados no MEV. Partes da coroa e da raiz foram removidas com disco de diamante, permanecendo apenas a região cervical. Essa superfície foi secada e limpa com Tubulicid Blue e EDTA. Para a moldagem, foi utilizada a silicona de adição President Jet (Coltene), com leve jato de ar. Uma banda de cobre foi afixada com cera, e as réplicas foram obtidas com resina epóxica Epoxydie (Ivoclar) proporcionada de acordo com as especificações do fabricante. A resina foi aplicada com seringa e leves jatos de ar, e deixada polimerizar por 24 horas, quando foi removida do molde. As réplicas e os espécimes originais foram metalizados e examinados no MEV. Os pacientes selecionados para o estudo in vivo apresentavam dentina radicular exposta, sem cárie, e lesões de erosão/abrasão. As moldagens foram realizadas 1 hora após o almoço, e os pacientes foram instruídos a escovar os dentes imediatamente após a refeição. Foram confeccionadas duas moldeiras individuais para cada área, sendo uma para a moldagem inicial de limpeza e outra para a final. Os dentes foram limpos com spray ar/água e secados com ar. Imediatamente após a moldagem inicial, os dentes foram limpos com Tubulicid Blue, e a moldagem final foi realizada. $O$ mesmo material de moldagem foi utilizado e removido após 6 minutos. Antes da obtenção das réplicas, também com a mesma resina epóxica utilizada in vitro, o molde foi desinfetado com glutaraldeído. Seguindo os procedimentos adotados no estudo in vitro, as réplicas foram limpas com água morna e sabão, secadas e montadas em suportes de alumínio para metalização e observação no MEV. Os resultados das observações in vitro demonstraram que, com pouco aumento, a réplica reproduziu fielmente detalhes da junção amelodentinária quando comparada ao original e, em alguns casos, uma provável deformação do molde 
não permitiu a observação de todos os detalhes no esmalte. A réplica in vivo possibilitou a observação de detalhes, confirmando que esse método pode ser válido para a observação e documentação da morfologia de tecidos duros cervicais. Segundo os autores, essa é uma técnica simples, higiênica, produz o mínimo de artefatos e com a vantagem de obter-se diversas réplicas a partir do mesmo molde.

Em 1991, AKPATA; WINTER ${ }^{4}$ desenvolveram uma técnica visando replicar os detalhes superficiais de ilhas de dentina exposta pela atrição oclusal in vivo. Um estudo in vitro preliminar foi realizado, moldando-se superfícies de dentes extraídos por razões periodontais, os quais apresentavam ilhas de desgaste menores que $2 \mathrm{~mm}$. Para a confecção das réplicas negativas, o material de moldagem Silflo foi proporcionado e levado com uma espátula sobre a superfície, sendo removido após 10 minutos. As réplicas foram metalizadas e observadas no MEV. No estudo in vivo, foram selecionados 6 primeiros molares inferiores. A atrição causou a exposição de ilhas de dentina que se apresentavam hipersensíveis ao estímulo térmico (gelo) e ao estímulo táctil (sonda exploradora). Antes da moldagem, os dentes foram limpos com jatos de água, isolados com roletes de algodão e secados com jatos de ar por 15 segundos. As réplicas positivas foram obtidas com resina epóxica Araldite, proporcionada e vibrada em ultrasom a fim de eliminar bolhas de ar, colocada com uma espátula dentro das moldagens e deixada polimerizar por 12 horas. Após esse período, as réplicas foram preparadas para observação no MEV. No estudo in vitro, a réplica negativa mostrou projeções do material de moldagem. As réplicas positivas obtidas no estudo in vivo mostraram as características dos túbulos dentinários e, ainda, a presença de linhas de fraturas. Dentre as conclusões, os autores ressaltam a 
importância do desenvolvimento de uma técnica que possibilite o acompanhamento in vivo das modificações superficiais (no caso, do diâmetro do túbulos dentinários) sem a necessidade de extração do elemento dentário. Assim, a técnica de réplica descrita é um método simples para essa finalidade. Os autores destacam, ainda, que o material de moldagem deve apresentar consistência leve e fluir no interior da camada superficial de dentina, favorecendo a reprodução de finos detalhes.

OYAMA; MATSUMOTO ${ }^{86}$, em 1991, empregaram a técnica de réplica para examinar a morfologia superficial dos túbulos na dentina hiperestésica. Nesse estudo, 105 incisivos e molares superiores e inferiores (67 dentes de pacientes do gênero masculino e 38 do gênero feminino) de pacientes com idade entre 20 e 60 anos foram selecionados. A superfície dos dentes foi, primeiramente, secada com algodão, lavada por 3 minutos alternando-se esponjas embebidas em álcool 70\% e solução de hipoclorito a $5 \%$ e, por fim, as áreas foram lavadas com água destilada e secadas com jatos de ar. O grau de sensibilidade dentinária foi mensurado através de uma Escala de Medida Verbal (EMV) de 0 a 3, utilizandose o jato de ar como estímulo. A dentina cervical hiperestésica foi examinada com sonda exploradora e por estímulo elétrico. As áreas hiperestésicas foram fotografadas e comparadas com as réplicas. Realizou-se a moldagem com hidrófilo Exaflex leve e pesado (GC Co.), manipulados através do Examix para evitar formação de bolhas. Camadas de resina Superbond (GC Co.) de rápida polimerização foram aplicadas na superfície do modelo com um pequeno pincel, e deixadas em temperatura ambiente por 30 minutos. As amostras de resina foram metalizadas e observadas no MEV. Avaliaram-se as réplicas de dentes com hiperestesia e túbulos dentinários abertos foram encontrados, assim como túbulos 
aglutinados e não visíveis. Nas áreas hiperestésicas, houve correlação entre a dor induzida pela sonda e os túbulos abertos. Entretanto, não houve uma correlação entre os estímulos elétrico e jato de ar. As margens mesial e distal foram as que mais freqüentemente apresentaram hiperestesia, seguidas daquelas da área gengival. Os resultados demonstraram uma correlação estatisticamente significante entre a morfologia dos túbulos dentinários e a hiperestesia dentinária.

WALSH; WALMSLEY ${ }^{125}$, em 1991, utilizaram a técnica de réplica associada à microscopia eletrônica de varredura a fim de avaliar os efeitos causados por instrumentos não cirúrgicos (ultra-som) nos tecidos gengivais. Para tanto, o paciente selecionado permaneceu sem higienização bucal por 6 horas antes do estudo. A superfície vestibular foi moldada com silicona de adição (Reprosil, De Trey, AG) e a resina epóxica (Araldite, Ciba Geygy Ltd.) foi vazada, obtendo-se o espécime controle. A limpeza foi, então, realizada com aparelho ultrasom na potência média. A superfície gengival foi secada, e a moldagem realizada como descrito acima. As réplicas foram metalizadas e observadas no MEV. A comparação das fotomicrografias indicou que o uso do ultrasom resultou em ruptura superficial da superfície gengival.

BRAEM; LAMBRECHTS; VANHERLE ${ }^{14}$, em 1992, realizaram réplicas para ilustrar o potencial do estresse de tração no desenvolvimento de lesões cervicais em forma de cunha in vivo. As superfícies de lesões cervicais e de algumas lesões restauradas foram moldadas com Xantopren Blue (Bayer), e as réplicas, foram obtidas com resina Araldite $\mathrm{DRL}$ (Ciba) injetada. As réplicas positivas foram metalizadas e observadas no MEV. Diferentes estágios de lesões puderam ser observados, levando os autores a concluir que pode ocorrer uma influência 
cumulativa das forças de tração na etiologia das lesões cervicais em forma de cunha.

Em 1993, RADFORD; RADFORD ${ }^{106}$ compararam, utilizando o MEV, a capacidade das réplicas de cobre e de resina epóxica de reproduzir a morfologia da placa dental e da mucosa palatal adjacente em portadores de estomatite, tendo pacientes saudáveis como controle. As moldagens foram feitas com silicona de adição (polivinil siloxano) de baixa viscosidade (President, Coltene). As réplicas de cobre foram obtidas seguindo a técnica descrita por LAMBRECHTS; VANHERLE; DAVIDSON, em 1981, e observadas diretamente no MEV. A fim de obter as réplicas de resina epóxica, foi confeccionada uma muralha de silicona de 5mm de altura ao redor do molde para acondicionar a resina epóxica (Taab Ltda.), vertida de tal modo a não formar bolhas. A polimerização da resina foi feita a $37^{\circ} \mathrm{C}$ por 24 h. Após esse período, a resina foi cuidadosamente separada do molde, as réplicas montadas em stubs de alumínio, metalizadas e observadas no MEV. Nesse estudo, as réplicas de cobre apresentaram-se superiores às de resina epóxica, possivelmente devido à viscosidade do material, que impediu a resina de fluir e copiar os detalhes menores obtidos no molde.

WESTERGAARD; PALLESEN; HOLMEN ${ }^{127}$, em 1993, descreveram um caso clínico de lesões de erosão/abrasão na superfície de esmalte em um paciente do gênero masculino de 27 anos de idade. Para comparação entre as lesões iniciais com o controle após 4 e 12 meses, os dentes foram moldados com silicona President (Coltene), e as réplicas obtidas com resina epóxica Stycast 1266, as quais, após a metalização, foram observadas no MEV. Comparando-se as imagens das réplicas iniciais e aquelas obtidas após o período de 4 meses, 
não foi possível reencontrar as estruturas de esmalte observadas nas réplicas iniciais. Após mais um período de 8 meses, o esmalte foi observado somente em áreas localizadas devido ao desgaste, tornando possível o aparecimento de túbulos dentinários. Assim, a perda de estrutura dentária causou modificações na superfície. A técnica de réplica utilizada não possibilitou a observação a nível de cristais.

BEVENIUS et al. ${ }^{11}$, em 1993, desenvolveram um método não invasivo para mensurar e documentar mudanças nos tecidos duros bucais, bem como investigar a micromorfologia de lesões cervicais. Foram selecionados 6 pacientes de ambos os sexos com idade entre 36 e 62 anos e que apresentavam lesões cervicais em forma de cunha. Colheram-se detalhes médicos, dentários, tipo de dieta e hábitos de higiene, bem como a quantidade e capacidade tampão da saliva. As réplicas das lesões foram obtidas com silicona de adição leve (President Jet) e moldeira individual. Após 24 horas e desinfecção em glutaraldeído a $2 \%$, os moldes foram vazados com resina epóxica Epoxy-die, e as réplicas metalizadas e observadas no MEV. Utilizou-se também um microendoscópio conectado a uma câmera de filmagem, o que possibilitou um aumento de 25 a 80 vezes. Os resultados indicaram que ambas as técnicas podem ser aplicadas como método de observação não invasivo.

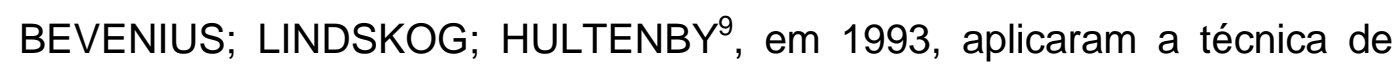
réplica para observar a micromorfologia da junção amelocementária de 50 prémolares jovens, os quais foram cuidadosamente extraídos por razões ortodônticas. As porções coronária e radicular foram removidas, permanecendo apenas a junção amelodentinária e algum cemento radicular e esmalte coronário. 
Após estocagem em álcool $70 \%$ por uma semana, a moldagem foi realizada com silicona de adição President (Coltene) leve, seguido do mesmo material na consistência pesada em um banda de cobre. Foram feitas 4 moldagens de cada espécime nas faces vestibular e lingual. A resina epóxica Epoxydie (Ivoclar) foi utilizada para a obtenção das réplicas positivas, que foram metalizadas e observadas no MEV. Os autores destacam que essa técnica de réplica apresenta vantagem no que diz respeito ao preparo do espécime original para observação no $\mathrm{MEV}$, pois não há necessidade de desidratá-lo. Os resultados sugeriram que a micromorfologia da junção amelocementária desses dentes e o potencial de erros de interpretação devido à técnica de preparo do espécime devem ser considerados quando resultados obtidos in vitro são extrapolados para condições clínicas.

Em 1996, YOSHIYAMA et al. ${ }^{132}$, utilizando a mesma técnica de biópsia descrita por eles em 1989, avaliaram a distribuição das estruturas tubulares da dentina radicular hipersensível e não sensível in vivo. Os resultados sugeriram que as estruturas tubulares encontradas na dentina hipersensível podem não só interferir na manutenção das características dos túbulos, como também impedir o processo físicomecânico de oclusão espontânea desses túbulos, mantendo, portanto, a sensibilidade dentinária.

BEVENIUS; LINDSKOG; HULTENBY ${ }^{10}$, em 1994, realizaram um estudo semelhante ao descrito anteriormente, tendo como objetivos documentar não apenas a ocorrência de exposição radicular clínica e subclinicamente, mas também descrever as características da micromorfologia superficial de tecidos dentários duros e da gengiva marginal adjacente em locais saudáveis ou não. 
Para tanto, selecionaram 13 mulheres e 14 homens com idade entre 19 e 25 anos que não fossem fumantes, apresentassem boa saúde geral e não estivessem sob tratamento ortodôntico ou restaurador. Os voluntários foram informados sobre o propósito do estudo, que recebeu a aprovação do comitê de ética da instituição. Os dentes foram limpos com spray ar/água, secados e, sob isolamento relativo, realizou-se a primeira moldagem para limpeza com o material Panasil Contact de presa rápida, removido após 4 minutos. A moldagem definitiva foi feita imediatamente após esse procedimento. A resina epóxica Epoxydie foi aplicada, e as réplicas obtidas foram metalizadas e observadas no MEV com aumento de 2000 vezes. Os pacientes foram reconvocados após 3 meses, quando os mesmos procedimentos foram realizados. A observação no MEV das réplicas da gengiva, avaliada clinicamente como saudável, mostrou freqüentemente sinais de inflamação gengival, como exudato e distorção no contorno gengival. Áreas saudáveis e desgastadas de esmalte exibiram trincas. A alta ocorrência de recessão gengival subclínica, dentina cervical exposta e inflamação gengival na dentição de adultos jovens, além da ausência de abrasão em tecidos duros e moles indicam a necessidade de rever os conceitos convencionais da etiologia da recessão vestibular e exposição radicular. Os autores concluíram que a técnica da réplica, associada à utilização de um material de moldagem hidrófilo e MEV em baixa voltagem, é um método simples e não invasivo para o estudo da micromorfologia superficial de tecidos moles e duros.

RAVNHOLT; KAABER ${ }^{107}$, em 1994, procuraram esclarecer a relação entre a rugosidade superficial da mucosa oral e sua reprodução na superfície correspondente em dentaduras de acrílico. O método clássico de mensuração da rugosidade não pode ser aplicado in vivo. Assim, moldagens da mucosa foram 
realizadas com silicona de adição (President, Coltene), e a réplica foi obtida com material epóxico Araldite (Ciba Geigy). Os autores concluíram que o método de mensuração utilizando a técnica de réplica silicona/resina epóxica possibilitou a visualização da rugosidade superficial de 120nm.

Em 1995, RIMONDINI; BARONI; CARASSI ${ }^{108}$ realizaram um estudo para determinar a relação entre a ultraestrutura da dentina e os sintomas clínicos de pacientes com dentina cervical exposta. Réplicas foram feitas de 28 dentes de 10 pacientes ( 5 homens e 5 mulheres) com idade entre 22 e 53 anos. Os critérios de seleção foram: presença de lesões cervicais não cariosas causadas por abrasão e/ou recessão gengival, dentes sem cáries, restaurações ou trincas, ausência de problemas periodontais e boa saúde geral do paciente. Os estímulos utilizados foram sonda clínica e jatos de ar, sendo o grau de sensibilidade mensurado através da Escala de Medida Verbal de 0 a 3. Todas as superfícies dentinárias foram limpas com bastonetes de algodão embebidos em solução de hipoclorito de sódio a 5\%, lavadas com água destilada e levemente secadas com jato de ar. As moldagens foram realizadas com material hidrófilo Express Light (3M), e a réplica obtida com Scutan (Espe). As superfícies foram condicionadas com ácido fosfórico a $37 \%$ por 20 segundos a fim de eliminar barreiras de minerais e expor os túbulos dentinários. Após esse procedimento, novas moldagens foram realizadas para obtenção de réplicas. Todos os espécimes foram colocados em stubs e metalizados para observação no MEV quanto à presença e morfologia (amorfa ou cristalina) da smear layer, densidade e diâmetro dos túbulos dentinários. Os autores observaram que o condicionamento ácido removeu a smear layer, enquanto que, em dentes não hiperestésicos, a remoção foi parcial ou ausente; além disso, os túbulos dentinários pareceram ser mais numerosos e 
abertos. Concluíram, ainda, que, em dentes hiperestésicos, a smear layer é fina, diferente em estrutura e provavelmente menos calcificada que a da dentina não hiperestésica. Os túbulos dentinários pareceram ser mais numerosos e amplos, o que reafirma o papel da smear layer na redução da permeabilidade da dentina em pacientes com hiperestesia.

MIXSON et al. ${ }^{78}$, em 1995, utilizando réplicas de resina epóxica, procuraram tanto descrever a morfologia da superfície dentinária de lesões de abrasão/erosão como também caracterizar quimicamente amostras in vivo de dentina esclerosada. Oito dentes (incisivos laterais, caninos, pré-molares e molares) de 3 pacientes ( 2 homens e 1 mulher, com idade entre 64 e 76 anos) foram avaliados. Após o isolamento relativo, os dentes foram lavados com spray ar/água e secados com jato de ar por 10 segundos. A silicona Express (3M) foi aplicada nas lesões, deixada polimerizar antes de ser removida, obtendo-se as moldagens da condição inicial. Todas as superfícies foram condicionadas com ácido fosfórico a $37 \%$ por 30 segundos, lavadas e secadas antes da obtenção de novas moldagens. As lesões foram, então preparadas, condicionadas com ácido fosfórico e restauradas com resina composta (Prisma APH). A resina epóxica preparada (Stycast 1266) foi levada a uma câmara de vácuo com pressão de 5 libras por um período de 10 minutos a fim de eliminar bolhas de ar. Cada molde foi limpo com ar comprimido, e a resina epóxica aplicada cuidadosamente para evitar a inclusão de bolhas, e deixada polimerizar por 24 horas. As amostras foram metalizadas e observadas no MEV. Com o objetivo de avaliar a qualidade de reprodução da réplica de resina epóxica, foram feitas réplicas de lesões cervicais em dentes extraídos, e comparadas com o original. Os resultados mostraram que, em adultos idosos, a superfície dentinária não apresenta 
morfologia tubular. Quando condicionadas com ácido fosfórico, a orientação dos túbulos variou dependendo da localização. Uma orientação lateral dos túbulos foi observada na margem gengival e nas paredes oclusais. Observaram-se túbulos abertos oblíquos no fundo da lesão. As amostras de dentina esclerótica não condicionadas sugeriram um aumento no conteúdo mineral/protéico nesses sítios de adesão.

DERRIEN; LE MENN²7, em 1995, avaliaram a precisão e a capacidade de reprodução de detalhes de três materiais a fim de obter moldes, utilizando, para tanto, o MEV e dois profilômetros bidimensionais. As moldagens de uma superfície padronizada foram realizadas com um material à base de polivinilsiloxano (Provil Medium Hydroactiv and P-soft, Bayer Dental), selecionado por ser hidrófilo e reproduzir detalhes menores que $0,02 \mathrm{~mm}$. Os materiais empregados na obtenção dos moldes foram gesso dentário (Fuji Rock), uma resina epóxica (Epoxydent) e uma resina à base de poliuretano (Steady-past), pois são altamente compatíveis com a silicona. Os resultados demonstraram que o gesso não reproduziu detalhes menores que $20 \mu \mathrm{m}$ devido ao tamanho de sua estrutura cristalina (15 a $25 \mu \mathrm{m}$ ), enquanto que a resina epóxica e o poliuretano reproduziram detalhes de 1 a $2 \mu \mathrm{m}$.

Com o objetivo de obter uma técnica de réplica, EKFELDT; FLÖYSTRAND; ÖILO ${ }^{33}$, em 1995, utilizaram dois diferentes materiais de moldagem (Xantopren Blue e President) e duas resinas epóxicas (Mertapox e Durcupan). As réplicas foram observadas no MEV. Os melhores resultados foram obtidos com a combinação da silicona President com as duas resinas epóxicas. 
ULUSU; ÖZTAS; TULUNOGLU ${ }^{121}$, em 1996, avaliaram a adaptação de um cimento de hidróxido de cálcio fotopolimerizável e um cimento de ionômero de vidro modificado por resina à superfície dentinária preparada com ponta diamantada, bem como o efeito de diferentes técnicas de inserção de resina composta in vitro. O estudo procurou determinar também se as fendas observadas eram reais ou artefatos provenientes da técnica de moldagem. Para tanto, 28 cavidades Classe I foram preparadas em dentes recém extraídos. Os cimentos foram aplicados e a resina composta inserida pela técnica incremental e também em um único incremento. Os espécimes foram embebidos em resina acrílica e acondicionados a $37^{\circ} \mathrm{C}$ por $24 \mathrm{~h}$. Após esse período, os espécimes foram seccionados na máquina de corte e limpos com ácido fosfórico a 37\% por 10 segundos a fim de remover a smear layer formada; em seguida, foram lavados e secados com jatos de ar. As moldagens foram realizadas com Permagum e removidas após a polimerização, montadas em stubs e metalizadas para observação no MEV. A comparação entre as superfícies dentárias e os respectivos moldes revelou a existência de fendas nos dentes, as quais não haviam aparecido nos moldes. Essas fendas foram, provavelmente, resultantes da dessecação dos tecidos, um procedimento necessário para observação no MEV. Assim, a utilização de réplicas é extremamente útil para evitar-se o surgimento de falsas fendas durante a análise. Os autores concluíram que não houve diferença entre os cimentos testados quando a técnica de inserção incremental de resina composta foi utilizada.

BRADY; WOODY ${ }^{13}$, em 1997, avaliaram a incidência, forma e outras características de lesões cervicais em 900 dentistas. A área a ser moldada foi previamente seca com jato de ar, e a moldagem feita com Citricon (Kerr), a qual 
permaneceu armazenada por três dias. Os moldes foram limpos três vezes com acetona, a resina epóxica foi aplicada e deixada polimerizar por uma semana, quando foram separadas do molde, metalizadas e observadas no MEV. As réplicas foram embebidas em resina epóxica, seccionadas e fotografadas no microscópio de luz para estudo dos defeitos.

GROSSMAN; MATEJKA ${ }^{49}$, em 1997, compararam sete métodos de avaliação da qualidade marginal de restaurações de amálgama Classe I utilizando a técnica de réplica. Foram confeccionadas 120 restaurações de amálgama em preparos Classe I em dentes pré-molares extraídos, divididos em 20 grupos e combinando materiais freqüentemente utilizados em clínica. Após os procedimentos restauradores, os dentes foram acondicionados por 3 meses (60 dentes) ou 1 ano (60 dentes). Após esse período, os dentes foram secados com ar em temperatura ambiente. Cada dente foi coberto com uma camada de esmalte, deixando-se as margens da restauração e $1 \mathrm{~mm}$ adjacente expostos. Nesse estágio, foram feitas réplicas das margens das restaurações com Impregum, e duas camadas de resina Araldite foram passadas sobre as moldagens para evitar a inclusão de bolhas de ar. Após 24 horas, essas réplicas foram preenchidas com resina epóxica e, após a polimerização, comparadas com o original em microscópio comum com aumento de 32X. Quando havia presença de bolhas, novas réplicas eram realizadas. As fotomicrografias foram feitas em MEV com aumentos de 10 a 20X. Em cada um dos grupos, o processo de obtenção de réplicas foi repetido após o desafio ácido e bacteriano. A técnica de réplica possibilitou observar diferenças entre os métodos de avaliação, e que o método, baseado primeiramente no tamanho da fenda marginal e, depois, na porcentagem de discrepância, pode ser melhor que os demais métodos avaliados. 
Em 1997, GILLAM; MORDAN; NEWMAN ${ }^{42}$ apresentaram uma revisão de literatura sobre métodos de avaliação de agentes anti-hiperestésicos in vitro, e descreveram as técnicas utilizadas para caracterizar seus efeitos na superfície dentinária preparada e a capacidade de esses agentes reduzirem a permeabilidade pela oclusão dos túbulos dentinários. Na consideração dos estudos in vivo, os autores citam a técnica de réplica preconizada por ABSI, ADDY; ADAMS, em 1989, para observar a superfície dentinária e, mais importante, para avaliar in vivo os efeitos dos agentes que atuam por obliteração dos túbulos dentinários.

CALZONETTI et al. ${ }^{17}$, em 1998, avaliaram a ocorrência de microfraturas após o preparo do ápice radicular com pontas ultrasônicas em dentes tratados endodonticamente, e de raízes seccionadas em cadáveres humanos in situ. Foram feitas moldagens antes e após o preparo dos ápices radiculares com um polivinilsiloxano (Exaflex leve e pesado) e moldeira individual. Os moldes foram montados em stubs e metalizados após secagem em ponto crítico. Inicialmente, as réplicas negativas foram observadas em um estereomicroscópio com aumento de 20X para avaliar a presença de microfraturas nos ápices radiculares. Depois, foram observadas no MEV com aumentos de 25, 50 e 100X. Os autores ressaltam que, ao contrário da maioria dos estudos, réplicas positivas não foram utilizadas nessa pesquisa porque as moldagens ou réplicas negativas foram suficientes para observar mudanças estruturais nos espécimes examinados. Além disso, essa técnica pode ser amplamente utilizada in vivo com pequenas alterações, como a utilização de um material de moldagem de presa mais rápida. 
POURGHADIRI; LONGHURST; WATSON ${ }^{105}$, em 1998, descreveram e avaliaram um novo método para controlar a remoção de superfície de esmalte mal formado. Foram selecionados 22 incisivos manchados de 12 pacientes com idade entre 9 e 15 anos. Metade da superfície vestibular dos dentes foi coberta com uma camada de resina para proteger a superfície do procedimento. A outra metade foi condicionada com ácido fosfórico a 35\% por 30 segundos, lavada e secada. O esmalte condicionado foi polido com ponta de acabamento e, depois, com taça de borracha. Procedeu-se à remoção da cobertura de resina, e a moldagem foi realizada com elastômero (Reprosil) com moldeira parcial. O mesmo tratamento foi feito na outra metade. Na observação direta dessas moldagens ou réplicas negativas, usou-se o microscópio confocal a fim de mensurar a perda de esmalte. Os autores concluíram que, ao contrário de outros métodos mais complexos e demorados, essa é uma técnica simples, rápida e eficaz para avaliar a perda de estrutura de esmalte. Além de ser bem tolerada pelo paciente, pode-se utilizar materiais que estão freqüentemente disponíveis no consultório dentário.

Em 1999, MORGAN; MARSHALL ${ }^{80}$ avaliaram, através da técnica de réplica, a ocorrência de fraturas na porção apical de dentes humanos submetidos a cirurgia periapical. Após a contenção do sangramento, 3mm da estrutura apical foram removidos com broca, e um polivinilsiloxano hidrófilo (Reprosyl tipo 1, Dentsply/Caulk) foi utilizado para a moldagem das raízes seccionadas. Após o tempo de presa de 5 minutos, o material foi removido. As réplicas foram obtidas a partir de uma resina epóxica (Magnolia Plastics, Chamblee, GA) vazada na moldagem em uma câmara de vácuo. Após o endurecimento, a resina foi separada da moldagem e metalizada para observação no MEV. 
KHAN et al. ${ }^{62}$, em 1999, aplicaram a técnica de réplica para descrever a incidência e localização específica de diferentes tipos de lesão cervical e sua relação com a atrição oclusal. Embora os autores não tenham explicado detalhadamente a técnica de réplica utilizada, a moldagem das lesões cervicais de 250 pacientes foi realizada com polivinilsiloxano, e as réplicas foram obtidas com resina epóxica. Vale ressaltar que as réplicas foram limpas com uma mistura de $70 \%$ de álcool e $30 \%$ de detergente antes de serem metalizadas e observadas no MEV.

WESTON; MOULE; BARTOLD ${ }^{128}$, em 1999, buscaram observar o efeito da secção de raízes com diferentes instrumentos, o material obturador e a interface entre o material obturador e as paredes radiculares, e o quanto isso poderia estar relacionado com a direção de rotação do instrumento. Para tanto, optaram por utilizar a técnica de réplica in vitro com a finalidade de minimizar os artefatos causados durante o preparo dos espécimes para MEV. As superfícies foram lavadas e secadas com jatos de ar. Uma moldagem de cada amostra foi feita com polivinilsiloxano leve (Extrude, Kerr) aplicado cuidadosamente com uma seringa. Após 7 minutos, o molde foi removido e descartado, pois serviu somente para retirada de debris e impurezas da superfície. Uma segunda moldagem foi, então, realizada a partir dos mesmos procedimentos. Após 24 horas, esses moldes foram cobertos com resina epóxica (Araldite Super Strength), procurando evitarse a formação de bolhas de ar, e deixada polimerizar em temperatura ambiente por 3 dias. As réplicas foram separadas do molde, metalizadas e observadas no MEV. Os autores concluíram que a técnica de réplica utilizada forneceu imagens de qualidade, apesar da formação de mínimas bolhas resultantes da inclusão de ar durante a moldagem. 
DIETSCHI; MOOR ${ }^{29}$, em 1999, avaliaram, in vitro, a adaptação interna e externa de restaurações de resina composta Classe II e inlays cerâmicas submetidas a cargas diferentes e ciclagem térmica. Após a conclusão das restaurações e antes de serem replicados, os dentes foram embebidos em resina epóxica e seccionados mesio-distalmente em 3 partes, polidos e limpos com ácido fosfórico a $37 \%$ por 2 minutos. As moldagens foram realizadas com President Light Body, cuidando-se para não desidratar demasiadamente o espécime antes da moldagem e, assim, evitar a ocorrência de artefatos. As réplicas positivas foram obtidas em resina epóxica, e os espécimes foram metalizados e observados no MEV com aumento de 1000X.

FERRARI et al. ${ }^{36}$, em 1999, avaliaram clinicamente a eficácia de um agente adesivo como dessensibilizante, com e sem o condicionamento ácido da dentina. Três meses antes do início da investigação, foram selecionados 30 pacientes com boa saúde geral e periodontal, dentina exposta vestibular e sensível aos estímulos hidrodinâmicos, totalizando 60 dentes. O grau de sensibilidade foi mensurado através da Escala Visual Analógica (EVA), de 0 a 10, utilizando-se jatos de ar por 1 segundo no baseline. Esses dentes foram divididos em 2 grupos, sendo o agente adesivo sob teste (Single Bond, 3M) aplicado com e sem o condicionamento prévio da dentina com ácido fosfórico a 35\% por 15 segundos. Repetiu-se a mensuração depois do tratamento e, também, após 1 e 2 semanas e 1 e 3 meses. Além disso, fez-se uma avaliação microscópica através da técnica de réplica em 5 dentes de cada grupo. No baseline, duas moldagens foram realizadas com poliéter (Permadyne), sendo uma antes e outra depois da aplicação do adesivo. Os moldes foram cuidadosamente limpos com ar comprimido, e uma resina epóxica foi utilizada para obtenção das réplicas, as 
quais polimerizaram por 24 horas. As réplicas foram montadas em stubs, metalizadas e observadas no MEV. No baseline, as réplicas foram feitas com o objetivo de observar a presença de túbulos dentinários expostos (com aumento de 2020X) e após a aplicação do adesivo, buscando-se observar a presença ou a ausência do mesmo (com aumento de 30X). A fim de avaliar a capacidade de reprodução das réplicas de resina, o mesmo procedimento foi realizado em dentes extraídos e comparadas com o original. A observação das fotomicrografias mostrou a presença de túbulos dentinários no baseline e a perda progressiva do agente adesivo com o decorrer do tempo, principalmente no Grupo 2, no qual o material estava completamente ausente após 1 mês.

MITCHELL; ABBARIKI; ORR ${ }^{77}$, em 2000, compararam o desempenho clínico de coroas totais cimentadas com diferentes cimentos e submetidas a forças de tração. Foram utilizados 125 dentes extraídos, divididos em cinco grupos de 25 espécimes. Para análise do modo de fratura, foram selecionados cinco espécimes de cada grupo. Uma moldagem de cada espécime foi realizada com Express (3M), e os moldes vazados com resina epóxica (Stycast) após 24 horas com auxílio de vibrador para evitar a inclusão de bolhas de ar. As réplicas positivas foram metalizadas e observadas no MEV. Como controle, réplicas positivas de resina epóxica foram preparadas a partir de superfícies dentinárias de dentes recentemente preparados.

Em 2000, ITTHAGARUN; TAY ${ }^{57}$, realizaram um estudo in vivo utilizando a técnica de réplica, para observar a superfície de dentina profunda condicionada com ácido, de dentes molares humanos submetidos à anestesia com e sem vasoconstrictor. Foram selecionados 23 molares de pacientes jovens, com cárie 
oclusal profunda em dentina a serem restaurados com resina composta. Os pacientes foram divididos em 2 grupos compreendendo 10 dentes, os quais receberiam ou não anestésico com ou sem vasoconstrictor. Três dentes que receberam anestésico sem vasoconstrictor e não foram condicionados com ácido após a remoção total da cárie foram moldados para controle. Nos 2 grupos, após a remoção da cárie, os dentes foram condicionados com ácido fosfórico a 32\% por 15 segundos, lavados e levemente secados com jato de ar, distante $5 \mathrm{~cm}$ da superfície oclusal. Imediatamente depois, uma moldagem com polivinilsiloxano (President light body) foi realizada, e o material foi colocado com espátula e acomodado com jatos de ar, completando com seringa e deixando polimerizar por 4 minutos e 15 segundos, quando foi removida. Os procedimentos adesivos e restauradores foram realizados. Para obtenção das réplicas, cada molde foi lavado com água e secado com jato de ar, e deixado por 24 horas a $60^{\circ} \mathrm{C}$. Uma resina epóxica para microscopia eletrônica de transmissão (TAAB 812) foi preparada e colocada nos moldes em câmara de vácuo, deixando-a polimerizar a $60^{\circ} \mathrm{C}$ por 48 horas. Os espécimes foram limpos com água destilada em ultrasom por 3 minutos, secados e metalizados. A utilização dessa técnica de réplica possibilitou observar o fluido dentinário em todas as amostras do Grupo I, no qual um anestésico sem vasoconstrictor foi utilizado. Três das amostras desse grupo estavam cobertas com um filme amorfo, diferente da smear layer presente no grupo controle. No Grupo II, orifícios tubulares isentos de fluido foram observados em todos os espécimes. Algumas estruturas sugestivas de prolongamentos odontoblásticos puderam ser observadas em túbulos dentinários.

Em 2001, LEONARD JUNIOR et al. ${ }^{70}$, avaliaram o efeito do clareamento vital noturno com peróxido de carbamida a 10\% (Nite White Classic) na morfologia 
da superfície de esmalte através da técnica de réplica associada à microscopia eletrônica de varredura. Foram selecionados 10 pacientes, que utilizaram o agente clareador por 8 a 10 horas durante 14 dias. A moldagem da superfície de esmalte de incisivos inferiores foi realizada no baseline, 14 dias e 6 meses após o tratamento. Antes de cada moldagem com Reprosil Light Body, as superfícies dos dentes foram limpas com peróxido de hidrogênio a 3\%, lavadas e secadas. Os moldes foram lavados, desinfetados, secados e vazados com resina epóxica Poly/Bed 812, a qual polimerizou à temperatura de $65^{\circ} \mathrm{C}$ durante uma noite. As réplicas positivas foram montadas em stubs e observadas no MEV com aumentos de 200 e 2000X. Como controle, dentes extraídos foram utilizados. Os resultados demonstraram que o clareamento realizado nessas condições causou alterações mínimas na superfície do esmalte, e que esses efeitos não aumentaram com o decorrer do tempo.

SCHMIDLIN et al., em $2001^{110}$, investigaram a perda de substância dentária utilizando a cintilação em combinação com profilometria e microscopia eletrônica de varredura para avaliar a rugosidade e as alterações na superfície radicular antes e após a instrumentação. Foram utilizados 40 dentes bovinos, os quais tiveram seus condutos radiculares preparados de diferentes modos. Realizou-se a moldagem com uma polivinilsiloxana de baixa viscosidade (President), e réplicas foram feitas com resina epóxica Stycast. Após 24 horas, as réplicas foram montadas em stubs e metalizadas para observação no MEV. Os resultados da microscopia demonstraram que a técnica de réplica possibilitou a observação de rasgos na superfície radicular.

O presente trabalho propõe-se a avaliar a técnica de réplica para a observação das características da dentina hiperestésica tratada e não tratada 
com um agente dessensibilizante à base de oxalato de potássio. Desse modo, incluiu-se uma revisão de literatura a fim de oferecer informações relevantes sobre a hiperestesia dentinária bem como o oxalato de potássio.

\subsection{HIPERESTESIA DENTINÁRIA}

Mecanismos da Hiperestesia Dentinária

THOMAS $^{117}$, em 1985, num estudo de revisão sobre a biologia pulpar e dentinária, relata que o complexo dentina/pré-dentina, como todo tecido conjuntivo, é caracterizado pela presença de células e de uma matriz extracelular. A dentina representa a porção mineralizada dessa matriz extra-celular, enquanto a pré-dentina, que não é mineralizada, separa o componente mineralizado dos odontoblastos, as células responsáveis pela formação do tecido.

A característica mais importante da dentina é a presença de túbulos dentinários, os quais se estendem perifericamente desde a junção odontoblasto/pré-dentina por toda a espessura desse tecido. A permeabilidade dentinária é uma conseqüência direta da presença de túbulos. O número de túbulos dentinários varia de 45 a $65000 / \mathrm{mm}^{2}$ na região próxima à polpa, de 29,5 a $35000 / \mathrm{mm}^{2}$ na região mediana e de 15 a $20000 / \mathrm{mm}^{2}$ próximo ao limite amelodentinário, com diâmetros de $2,5 \mu \mathrm{m}, 1,2 \mu \mathrm{m}$ e 0,9 $\mu \mathrm{m}$, respectivamente ${ }^{38}$. Essa aparente diminuição no número de túbulos está relacionada com o aumento da área de superfície de dentina em direção à junção amelodentinária. O túbulo dentinário é composto por dentina peritubular, processo odontoblástico, colágeno, nervos e fluido dentinário, componentes que influenciam de algum modo a permeabilidade dentinária.

O complexo dentino-pulpar tem abundante suprimento nervoso ${ }^{65}$, sendo a dentina um tecido altamente sensitivo e com um comportamento diferente quando 
comparado a outros tecidos do corpo. Na dentina, todo e qualquer estímulo como preparo cavitário, alterações de temperatura, soluções hipertônicas ou desidratação causam a mesma sensação de dor. A pele, por exemplo, apresenta terminações que distinguem diferentes estímulos como calor, frio, toque ou $\operatorname{dor}^{65,39}$

O mecanismo exato, através do qual o estímulo é transmitido da superfície dentinária para a polpa, não é claramente conhecido. Assim sendo, várias teorias têm sido propostas ${ }^{31}$ no sentido de melhor caracterizá-lo.

Segundo KRAUSER ${ }^{66}$, em 1986, e DOWELL; ADDY30, em 1993 seriam:

1. os odontoblastos e seus prolongamentos atuam como receptores dentinários, participando na iniciação e na transmissão de um estímulo.

2. os nervos da polpa, e não da dentina, são os receptores da dor, sendo estimulados pelo mecanismo hidrodinâmico.

Com relação à primeira proposta, alguns autores como FRANK ${ }^{37}$, em 1968, COLLAERT; FISCHER ${ }^{22}$, em 1991, afirmam que não existe sinapse entre os odontoblastos e os nervos pulpares, e os prolongamentos odontoblásticos não se estendem além de um terço até à metade do comprimento dos túbulos dentinários. Desse modo, apesar de evidências de que a dentina possui terminações nervosas, não existe uma explicação clara de como um estímulo aplicado à dentina pode influenciar fibras nervosas que, aparentemente, não penetram em toda a extensão dos túbulos dentinários ou de maneira uniforme na dentina ${ }^{113}$.

Dentre as várias teorias que tentam explicar o mecanismo da hiperestesia dentinária, a Teoria da Hidrodinâmica, baseada em uma suposta ausência de fibras nervosas ${ }^{64}$, parece ser a mais aceita até o momento. 
Conforme se explicou anteriormente, a dentina apresenta cerca de 30.000 túbulos por $\mathrm{mm}^{2}$, os quais são preenchidos com um material fluido ou semi-fluido e cuja movimentação é impedida pela presença do esmalte, que veda esses túbulos no limite amelo-cementário. Um estímulo de qualquer natureza, como o preparo cavitário, alterações de temperatura (alimentos quentes ou frios), soluções hipertônicas (substâncias doces ou ácidas), desidratação (jato de ar ou respiração), pressão (ponta do explorador) pode determinar uma variação da pressão intrapulpar por movimentação do fluido dentinário em direção à polpa ou em sentido contrário, dependendo da natureza do estímulo. Assim, através das terminações nervosas próximas à camada odontoblástica, ocorre a transmissão dessa sensação até a polpa. Se houver perda do esmalte da região cervical por erosão ou abrasão, ou na presença de recessão gengival, a dentina fica exposta ao meio bucal e, em particular, os túbulos dentinários. A movimentação do fluido nesses túbulos, por gerar uma pressão positiva ou negativa conforme a sua direção, provoca a dor ${ }^{89}$.

O movimento dos fluidos no interior dos túbulos dentinários foi, primeiramente, reportado por $\mathrm{GYSI}^{51}$, em 1900. BRÄNNSTRÖM ${ }^{15}$, em 1966, buscou uma explicação alternativa para a sensibilidade da dentina e partiu do princípio de que não existem fibras nervosas na mesma, reintroduzindo, então, o conceito de GYSI sobre a Teoria da Hidrodinâmica. Segundo essa teoria, alguns estímulos provocam rápido movimento do fluido dentinário (2 a $4 \mathrm{~mm} / \mathrm{seg})^{65}$ nos túbulos $^{31}$; esse movimento ativa as terminações nervosas responsáveis pela dor na interface dentina-polpa ${ }^{129}$.

BRÄNNSTRÖM; ASTRÖM ${ }^{16}$, em 1972, ressaltam que experimentos in vivo e in vitro em dentes humanos têm dado suporte à hipótese de que a hidrodinâmica é responsável pela transmissão do estímulo da dor da superfície 
dentinária para as terminações nervosas no complexo dentino-pulpar e/ou polpa. Os autores afirmam que o movimento do conteúdo tubular na porção pulpar para fora dos túbulos é mais responsável pela manifestação da dor do que o deslocamento na direção oposta. A diferença da resposta hidrodinâmica ao frio, ar e calor parece corresponder a diferenças observadas clinicamente na característica da dor. Os autores concluem, então, que há dois tipos de dor nos dentes, possivelmente mediadas por dois tipos de nervos.

Com base na Teoria da Hidrodinâmica, seria lógico concluir que os dentes com hiperestesia dentinária deveriam apresentar túbulos dentinários abertos na superfície dentinária e desobstruídos até a polpa. ABSI; ADDY, ADAMS ${ }^{1}$, em 1987, avaliaram in vitro a abertura dos túbulos dentinários na dentina cervical sensível e não sensível e observaram que, comparando-se dentes não sensíveis com dentes hiperestésicos, existe um aumento significativo no número de túbulos por área de aproximadamente oito vezes nos dentes hiperestésicos. Observaram ainda que, nesses dentes com sensibilidade, os túbulos apresentaram-se significativamente mais amplos.

Em 1989, YOSHIYAMA et al ${ }^{133}$. propuseram a utilização de uma técnica de biópsia in vivo para investigar as mudanças estruturais nos túbulos dentinários em áreas sensíveis e não sensíveis de lesões em forma de cunha. Os resultados da microscopia revelaram que as áreas de dentina sensíveis apresentaram maior porcentagem de túbulos dentinários abertos. Por outro lado, nas áreas não sensíveis, os túbulos dentinários encontravam-se obstruídos, e a superfície era extremamente lisa. Em 1990, os mesmos autores ${ }^{134}$ avaliaram, através de microscopia eletrônica de transmissão, as características da dentina radicular hipersensível e não sensível in vivo, utilizando a técnica de biópsia descrita em 1989. As imagens da microscopia revelaram claramente que, nas áreas não 
sensíveis, o lúmen da maioria dos túbulos apresentava-se obstruído por cristais minerais e, nas áreas sensíveis, os túbulos apresentaram-se vazios e circundados por dentina peritubular e intertubular.

Segundo RIMONDINI; BARONI; CARASSI ${ }^{108}$, em 1995, a dentina hiperestésica apresenta uma smear layer mais fina, diferente em estrutura e, provavelmente, menos calcificada que a dentina não sensível. Além disso, os túbulos dentinários parecem ser mais numerosos e amplos. Essas características dão suporte à teoria do aumento da permeabilidade hidrodinâmica da dentina hiperestésica.

PASHLEY ${ }^{90}$, em 1992, numa revisão de literatura sobre permeabilidade e sensibilidade dentinária, afirmou que a Teoria da Hidrodinâmica é baseada na premissa de que a dentina sensível é permeável em toda a extensão dos túbulos. Essa condição permite a difusão de produtos bacterianos pela dentina até à polpa, causando irritação dos tecidos pulpares. Entretanto, a movimentação do fluido dentinário para fora é lenta e tende a deixar que substâncias exógenas passem pelos túbulos abertos. O autor conclui que o equilíbrio entre a difusão de substâncias exógenas, sejam estas de origem bacteriana ou agentes dessensibilizantes, e a limpeza proporcionada pelo fluido merecem mais estudo. Acrescenta, ainda, que qualquer tratamento que reduza a permeabilidade dentinária deverá diminuir a sensibilidade. Esse entendimento do papel da permeabilidade dentinária no processo de hipersensibilidade faz com que métodos simples de estudo in vitro examinem o potencial de novos agentes terapêuticos na oclusão dos túbulos.

Formas de Tratamento - Obliteração dos Túbulos Dentinários

Como já foi mencionado, a teoria mais aceita para explicar o mecanismo da hiperestesia dentinária é a Teoria da Hidrodinâmica. Um tratamento eficaz da 
hiperestesia dentinária seria, portanto, a obliteração dos túbulos dentinários a fim de reduzir ou inibir o movimento dos fluidos nos túbulos ou a permeabilidade dentinária $^{129}$. Desse modo, o objetivo clínico do tratamento da hiperestesia dentinária é promover o selamento permanente dos túbulos dentinários ${ }^{31}$ através de agentes que interagem com o mecanismo hidráulico da dentina e influenciam a condutibilidade da mesma.

GROSSMANN $^{48}$, em 1935, relacionou algumas características que devem ser consideradas quando se escolhe o agente anti-hiperestésico, tais como: não ser irritante à polpa, ser de fácil aplicação, ter ação rápida (alívio imediato), promover efeito duradouro, não manchar ou descolorir o dente, ter efetividade comprovada e ser de baixo custo.

Os agentes que obliteram os canalículos dentinários podem atuar através da precipitação de proteínas, deposição de cristais nos túbulos dentinários ou de partículas, aplicação de película impermeabilizadora, aplicação de raios laser ou por técnicas restauradoras convencionais ${ }^{100}$. A seguinte Figura, adaptada de SENA ${ }^{114}$, em 1990, resume os diferentes agentes e terapias anti-hiperestésicas com efeito oclusivo sobre os canalículos dentinários:

\begin{tabular}{|l|l|}
\hline PROVÁVEL MECANISMO DE AÇÃO & AGENTES OCLUSIVOS \\
\hline Precipitação de Proteínas & - Nitrato de Prata \\
& - Formalina \\
& - Cloreto de Zinco \\
\hline Deposição de Partículas & - Oxalato de Potássio \\
& - Hidróxido de Cálcio \\
& - Compostos Fluoretados \\
& - lontoforese \\
& - Cloreto de Estrôncio \\
& - Brunidura \\
\hline Película Impermeabilizadora & - Vernizes \\
& - Adesivos Dentinários \\
\hline Procedimentos Restauradores & - Sistemas adesivos \\
& - Resinas Compostas \\
& - Cimentos de lonômero de Vidro \\
\hline
\end{tabular}

Figura 2.1: Agentes e procedimentos com efeito oclusivo sobre os canalículos dentinários. 
Em princípio, a obliteração dos túbulos é conseguida pela reação de um sal solúvel com o líquido dos túbulos dentinários, reagindo com íons cálcio e potássio provenientes da dissolução da hidroxiapatita que constitui as paredes dos túbulos dentinários. Essa reação resulta em compostos insolúveis que se precipitam como cristais e obliteram a embocadura dos túbulos, eliminando a hiperestesia dentinária $^{39}$. COOFEY et al. $^{23}$, em 1970, pesquisaram o fluido dentinário, e os resultados revelaram que o fluido é um líquido amarelo claro, quase transparente e, ao microscópio, não apresentou células ou grânulos. Quanto à composição, os autores concluíram que o fluido dentinário contém sódio, potássio e cloro e, provavelmente, é saturado em íons cálcio e potássio; no entanto, suas concentrações exatas não foram obtidas. As concentrações de sódio e potássio, porém, aproximaram-se do fluido intersticial, o que levou os autores a concluírem que o fluido dentinário se localiza extracelularmente e não é derivado do citoplasma ou do processo odontoblástico. Pode-se dizer, então, que o oxalato de potássio reage tanto com a dentina quanto com o fluido dentinário.

O oxalato de potássio combina as propriedades de oclusão dos túbulos dentinários com a inibição da atividade neural ${ }^{91,82,98}$. Segundo GRENHILL, PASHLEY ${ }^{47}$, em 1981 e GILLAM et al. ${ }^{45}$, em 1999, o selamento dos túbulos dentinários pode ser conseguido com a aplicação tópica de oxalatos que formam precipitados insolúveis na embocadura e no interior dos túbulos dentinários, reduzindo o fluxo do fluido e controlando a sensibilidade da dentina exposta. Esse tipo de tratamento tem sido reportado por muitos autores, que têm utilizado o oxalato de potássio em diferentes concentrações.

A remissão espontânea da hiperestesia, ou seja, o processo de dessensibilização natural, embora lento, é uma proteção natural e pode ocorrer devido a processos fisiológicos, como a remineralização pela saliva, por formação 
de dentina secundária e terciária ${ }^{66,89}$ e, ainda, pela formação de smear layer através da escovação, procedimentos periodontais e preparo cavitário ${ }^{129}$. ORCHARDSON et al. ${ }^{85}$, em 1994, afirmam que a hiperestesia resultante de tratamento periodontal cessa após 3 ou 4 semanas como resultado da oclusão dos túbulos dentinários. Entretanto, a sensibilidade persiste entre 10 a $15 \%$ destes pacientes. A razão de falha no mecanismo natural em alguns pacientes é desconhecida, mas pode estar relacionada a fatores locais, tais como a composição e o fluxo da saliva. Existem casos, porém, em que a sintomatologia é permanente e, para estes, muitos são os tratamentos propostos.

A hiperestesia dentinária é, talvez, mais uma complexidade de sintomas do que uma doença propriamente dita, e a severidade da dor ou como o paciente a interpreta é que determina qual tratamento deve ser realizado ${ }^{31,31}$.

\section{Efeito Placebo}

Alguns estudos clínicos têm relatado uma diminuição da sensibilidade dentinária com o uso de placebos, utilizados como controle tanto para determinar a eficácia de substâncias ativas bem como avaliar as mudanças psicológicas, no sistema nervoso ou em ambos com relação à percepção da hiperestesia.

O placebo é uma substância que o paciente acredita ser eficaz, embora não contenha o agente ativo, e o chamado "efeito placebo", um dos fenômenos mais fascinantes na medicina, ocorre quando o paciente melhora após receber esse tratamento ${ }^{119,120}$.

A hiperestesia dentinária é, segundo WICHGERS; EMERT ${ }^{129}$, em 1996, um assunto complexo devido aos fatores psicológicos e à natureza subjetiva da dor, pois trata-se de uma dor crônica com períodos de agudização e, como tal, envolve componentes psicológicos. 
Segundo TURNER ${ }^{120}$, em 1999, o fator emocional do paciente tem grande influência nos resultados. A resposta ao placebo em determinada situação não significa que o paciente irá responder favoravelmente a essa mesma substância em uma situação diferente. O "efeito placebo" provavelmente reduz o estresse e a ansiedade, podendo afetar o corpo e intensificar sintomas individuais. Se o paciente acredita que o tratamento vai melhorar sua condição, isso pode diminuir sua ansiedade, preocupação e, consequentemente, os sintomas.

Outros aspectos considerados para explicar o efeito placebo estão relacionados com a influência do clínico e com a personalidade, expectativa e condescendência do paciente. De acordo com TROWBRIDGE; SILVER ${ }^{118}$, em 1990, e TURNER ${ }^{119,120}$, em 1999, o maior fator de resposta ao placebo é a qualidade da relação entre o paciente e o profissional. Quando o profissional demonstra amizade, interesse, simpatia pelo paciente e positividade em relação ao tratamento, ele pode motivar o paciente a obter alívio. Em outras palavras, se o profissional afirma que o tratamento será eficaz, provavelmente o será.

O "efeito placebo" é, então, decorrente de interações fisiológicas e psicológicas, sendo o relacionamento entre o paciente e o profissional o principal fator de resposta positiva ao placebo. Além disso, um comportamento emocional positivo e motivado pode ativar o sistema central de inibição da dor do organismo, o qual controla o estímulo doloroso da periferia através da liberação de endorfinas pelo sistema nervoso central ${ }^{118}$.

\subsection{OXALATO DE POTÁSSIO}

\section{Estudos Laboratoriais}

Inúmeros são os estudos laboratoriais que comprovam a eficácia do oxalato de potássio no alívio da hiperestesia dentinária. 
GREENHILL; PASHLEY ${ }^{47}$, em 1981, avaliaram in vitro a capacidade de os agentes empregados como dessensibilizantes dentinários atuarem na redução da movimentação do fluido pela dentina. O oxalato de potássio a $30 \%$ obteve o melhor resultado, alcançando níveis de 98,4\% na redução da permeabilidade dentinária. Isso pode ser devido ao fato de que os cristais de oxalato de cálcio formados mostraram-se de tamanho semelhante ao diâmetro dos túbulos dentinários, penetrando no interior dos mesmos.

PASHLEY et al. ${ }^{95}$, em 1984, avaliaram in vitro o efeito de diferentes dentifrícios dessensibilizantes na condutibilidade hidráulica da dentina. Os dentifrícios comerciais utilizados foram Thermodent, Sensodyne, Promise, Denquel e Crest, além de um dentifrício experimental contendo oxalato de potássio a $2 \%$. Para cada dentifrício comercial, exceto para o Thermodent, usouse um dentifrício placebo idêntico aos demais, mas caracterizado pela ausência do ingrediente ativo. O dentifrício experimental que continha oxalato como componente ativo foi claramente superior aos demais $(95,0 \%)$, produzindo uma redução imediata na sensibilidade dentinária. Não houve diferença estatisticamente significante entre os demais dentifrícios e os placebos, o que pode ser atribuído ao fato de que algumas partículas abrasivas contidas nesses dentifrícios poderiam ser pequenas o suficiente para penetrar no interior dos túbulos dentinários.

PASHLEY; GALLOWAY92, em 1985, avaliaram o efeito do oxalato de potássio em superfícies de dentina a fim de descobrir de que maneira o mesmo reage com a smear layer, ou seja, reduzindo sua permeabilidade ou aumentando sua resistência ao condicionamento ácido. Depois de obtidos os discos de 
dentina, a smear layer foi tratada com : cloreto de potássio por 2 minutos (Grupo 1 - controle); oxalato de di-potássio neutro por 2 minutos (Grupo 2); solução de oxalato de potássio monohidrogenado a 3\% por 2 minutos - solução ácida com $\mathrm{pH}=2$ (Grupo 3), e oxalato de dipotássio a 30\% por 2 minutos, seguido de oxalato de potássio monohidrogenado a 3\% por 2 minutos (Grupo 4). Após o tratamento, cada grupo foi condicionado com ácido cítrico a $6 \%$ por 2 minutos. Os resultados mostraram que os discos tratados com cloreto de potássio não tiveram a condutibilidade alterada, e foram susceptíveis ao desafio ácido. Por outro lado, os discos tratados com soluções de oxalato tiveram uma redução significativa da permeabilidade e foram resistentes ao condicionamento ácido. O tratamento combinado de oxalatos não somente remove a smear layer e a substitui por uma camada de precipitados cristalinos, a qual oclui a dentina e é ácido resistente, como também resulta em uma superfície rica, tanto em cálcio como em carboxilatos, que auxiliam na adesão química.

PASHLEY; DEPEW ${ }^{91}$, em 1986, avaliaram o efeito da smear layer, do verniz cavitário e do oxalato na permeabilidade dentinária e na microinfiltração. 0 oxalato reduziu a permeabilidade em $98,25 \%$ e não foi diferente quando a direção da filtração foi modificada. Como os cristais de oxalato de cálcio são insolúveis e resistentes ao condicionamento ácido, a permeabilidade dentinária, tendo o oxalato como agente intermediário, foi menor do que com qualquer outro agente testado.

PASHLEY; ANDRINGA; EICHMILLER ${ }^{93}$, em 1991, compararam a eficácia do oxalato de ferro, oxalato de potássio e do condicionador dentinário Tenure na redução da permeabilidade dentinária in vitro. Os resultados indicaram que o 
tratamento da dentina por 10 segundos proporcionou, para todos os agentes, um aumento da permeabilidade dentinária. Quando se aumentou o tempo para 30 segundos, houve uma diminuição da permeabilidade dentinária para as soluções à base de oxalato, sendo estas ainda mais eficazes com 60 segundos de aplicação. O tratamento com Tenure, que contém oxalato de alumínio a 2,5\%, não reduziu a permeabilidade dentinária aos níveis do tratamento realizado com oxalato. Tal ocorrência pode ser devida à concentração reduzida de oxalato de alumínio bem como pela necessidade de um tempo maior de aplicação para que se formem sais insolúveis, o que, para as soluções à base de oxalato, parece darse após 30 segundos de aplicação.

KNIGHT et al. ${ }^{63}$, em 1993, examinaram, por microscopia eletrônica de varredura, o efeito de obliteração dos túbulos dentinários através da realização de procedimentos mecânicos e químicos. Os espécimes de dentina foram cortados transversalmente e divididos em dois grupos, sendo um experimental e outro grupo controle. Os tratamentos mecânicos foram realizados através de instrumentação contínua por 20 segundos com instrumentos de diferentes composições (metálicos e plásticos). Os tratamentos químicos incluíram resina composta, fluoretos, oxalatos de potássio e férrico, glicerina e nitrato de potássio. Os resultados revelaram que, entre os agentes mecânicos, a cureta afiada apresentou uma obliteração mais consistente e completa dos túbulos, e os instrumentos plásticos não tiveram efeitos oclusivos sobre os túbulos. Entre os tratamentos químicos, a resina composta fotopolimerizável promoveu uma obliteração completa dos túbulos. O oxalato de potássio a 3\% obliterou os túbulos com um grande número de pequenos cristais espalhados na superfície dentinária, mas a maioria dos cristais desapareceu após um spray de água. Os agentes à 
base de flúor e glicerina não apresentaram nenhum efeito oclusivo sobre os túbulos.

SHONO et al. ${ }^{115}$, em 1994, avaliaram in vitro a atuação de uma nova formulação de oxalato de potássio mais oxalato de alumínio na redução da permeabilidade dentinária e na alteração da superfície dentinária através de microscopia eletrônica de varredura. As medições da permeabilidade foram executadas antes e após a aplicação de uma solução salina (controle) e da solução experimental (oxalato de dipotássio a 5\% + oxalato de alumínio a 5\% em ácido nítrico a 2\%, $\mathrm{pH}$ 2) por 10, 30 e 60 segundos. O tratamento da smear layer com a solução de oxalato produziu uma obliteração significativa dos túbulos. 0 tratamento da dentina condicionada com a solução experimental de oxalatos formou precipitados de tamanhos menores que os anteriores. O tamanho dos cristais e a espessura da camada de precipitado aumentou com o tempo do tratamento. Os resultados indicaram que a nova formulação de oxalatos obstruiu significativamente os túbulos dentinários, podendo ser utilizada como agente antihiperestésico ou mesmo como forrador cavitário.

MONGIORGI; PRATI ${ }^{79}$, em 1994, avaliaram o efeito de soluções de oxalato na condutibilidade hidráulica da dentina in vitro. Os 25 espécimes foram divididos em 5 grupos, e cada superfície dentinária recebeu o tratamento das soluções experimentais e controle por 2 minutos. Antes do tratamento, todos os espécimes foram condicionados com ácido fosfórico a 37\% por 2 minutos, a fim de remover a smear layer e simular a máxima permeabilidade (100\%). O tratamento com solução de cloreto de sódio a $0,9 \%$ (controle negativo) não teve efeito na permeabilidade dentinária. $\mathrm{O}$ tratamento com ponta diamantada (controle 
positivo), tendo em vista a criação da smear layer, reduziu a permeabilidade de 100\% para 2,9\%. Os espécimes tratados com Dentine Protect (ácido oxálico) tiveram sua permeabilidade reduzida para $3,9 \%$ do valor máximo. Todas as soluções de oxalato reduziram a permeabilidade a valores tão baixos quanto aos da smear layer $(3,5 \%$ e $2,2 \%)$ e não houve diferenças estatísticas entre os tratamentos.

LING; GILLAM ${ }^{71}$, em uma revisão sobre a eficácia dos agentes dessensibilizantes no tratamento da hiperestesia dentinária publicada em 1996, ressalta os diferentes tipos de tratamento para essa condição clínica. Entre os agentes que atuam por obliteração dos túbulos dentinários, ressalta, entre outros agentes, experimentos laboratoriais nos quais o oxalato de potássio diminuiu a permeabilidade dentinária. Entretanto, os efeitos desse oxalato tiveram curta duração, já que pouco oxalato de potássio estava presente após sete dias.

O estudo in vitro realizado por PEREIRA, SEGALA; CARVALHO ${ }^{101}$, em 1996, teve por objetivo aumentar a reação do substrato dentinário ao oxalato de potássio. Foram utilizados 60 discos de dentina, divididos em 4 grupos, sendo 3 grupos tratados com 3 diferentes formulações de oxalato de potássio monohidratado (gel a $3 \%$ com pH 4 - Oxa-Gel ${ }^{\circledR}$; gel a $6 \%$ com pH 4 e gel a $6 \%$ com $\mathrm{pH} 2,5$ ) aplicados por 3 minutos. O Grupo 4 foi tratado com fluorfosfato acidulado a 1,23\%, pH 4, por 4 minutos. Cada grupo foi subdividido em 3 subgrupos, que receberam os seguintes tratamentos: a) condicionamento ácido com ácido cítrico a $6 \%$ por 1 minuto, lavados e secados com ar; b) condicionamento ácido e lavado somente, mantendo-se a umidade; c) condicionado, lavado e secado com papel absorvente; d) condicionado, não 
lavado e secado com ar; e) condicionado e secado com papel absorvente. Os resultados revelaram que todos os grupos apresentaram cristais de oxalato precipitados na embocadura dos túbulos. As condições condicionado/lavado/úmido e condicionado/não lavado mostraram os melhores resultados na oclusão dos túbulos.

JAIN et al. ${ }^{58}$, em 1997, avaliaram in vitro, por meio de MEV e microanálise, o efeito de 4 agentes dessensibilizantes dentinários na oclusão dos túbulos, as modificações na superfície dentinária e os efeitos da saliva e da escovação. Os espécimes foram divididos em 5 grupos de 10 dentes cada. No Grupo 1 (controle), não se realizou nenhum tratamento; no Grupo 2, a superfície dentinária foi tratada com Sensodyne Dentin Desensitizer (solução de oxalato de ferro a 6\%); no Grupo 3, foi utilizado Therma - Trol Desensitizer gel (solução de oxalato de potássio); o Grupo 4 foi tratado com Gluma Dentin Desensitizer (solução aquosa de glutaraldeído e HEMA) e, no Grupo 5,os espécimes foram tratados com All Bond. Os resultados mostraram que Sensodyne exibiu maior quantidade de oclusão de túbulos entre os dentes que não receberam escovação, seguido de Therma-Trol, Gluma e All Bond, nessa ordem. A escovação aumentou a oclusão dos túbulos em todos os casos, exceto para Sensodyne.

LING et al. ${ }^{72}$, em 1997, avaliaram, in vitro, o potencial do oxalato férrico (Sensodyne Sealant) e do oxalato de potássio (Butler Protect) de obliterar os túbulos dentinários. Após a aplicação desses agentes, os discos de dentina foram avaliados por meio de microscopia eletrônica de varredura e microanálise por raio-x. Os resultados demonstraram que o oxalato férrico produziu cristais que obliteraram quase todas as aberturas tubulares, e mostrou ser superior ao oxalato 
de potássio. Foi observada a presença de componentes abrasivos (sílica e cálcio) tanto na superfície quanto no interior dos túbulos dentinários, indicando, assim, um certo potencial terapêutico desses dois componentes. Tais resultados sugerem que, in vitro, os agentes anti-hiperestésicos apresentam a propriedade de ocluir os túbulos, podendo ser indicados para tratamento in vivo.

PEREIRA et al. ${ }^{103}$, em 1997, avaliaram, in vitro, a capacidade de um gel de oxalato de potássio a $3 \%$ e de um gel de fluoreto a 1,23\% em reduzir o índice de filtração da água deionizada através da dentina secada com ar ou deixada levemente úmida. Após a obtenção dos discos de dentina, da remoção da smear layer com EDTA e da criação de nova smear layer com discos abrasivos, os espécimes foram submetidos a filtração e os índices foram mensurados para ambos os géis testados, sob as duas condições, e comparados à filtração básica. Os índices de filtração foram, ainda, mensurados após o desafio com ácido cítrico a $6 \%$. Os resultados demonstraram que o gel de oxalato de potássio a $3 \%$ foi capaz de reduzir a filtração do fluido dentinário a níveis similares aos obtidos com a smear layer, mesmo após o desafio ácido.

GILLAM; MORDAN; NEWMAN ${ }^{42}$, em 1997, apresenta uma revisão da literatura no que diz respeito às avaliações in vitro de agentes anti-hiperestésicos, as técnicas utilizadas para caracterizar os efeitos na superfície dentinária preparada, e a habilidade desses agentes em reduzir a permeabilidade dentinária através da obliteração dos túbulos dentinários. Além disso, ressaltaram os achados baseados no modelo do disco de dentina proposto por PASHLEY, que sugeriu a utilização de discos de dentina para avaliar a permeabilidade dentinária. Nesse modelo, antes da aplicação dos produtos, o disco de dentina deve ser 
limpo com ácido cítrico a $6 \%$ por 2 minutos, lavado em água destilada e secado. Dentre os estudos in vivo, a técnica de réplica é citada pelos autores como a mais indicada, pois proporciona a avaliação direta dos efeitos dos agentes terapêuticos. Mesmo assim, existe uma dificuldade em limpar a superfície dentária sem promover a formação de smear layer.

CAMPS et al. ${ }^{18}$, em 1998, compararam o efeito in vitro de 3 agentes antihiperestésicos na condutibilidade hidráulica da dentina humana. Foram obtidos 40 discos de dentina com $0,5 \mathrm{~mm}$ de espessura a partir de terceiros molares hígidos e recém extraídos. O lado pulpar dos discos foi condicionado com ácido fosfórico a 37\% por 15 segundos, lavado e secado. O lado oclusal foi limpo com ultrasom por 30 minutos. A condutibilidade hidráulica de cada disco foi mensurada antes dos tratamentos e determinada como 100\%. Dos 40 discos, 10 não foram tratados, compondo o grupo controle. O outros 30 discos foram tratados com agentes anti-hiperestésicos comerciais, sendo um à base de oxalato de potássio (Protect), um à base de resina (Gluma Desensitizer) e um agente à base de oxalato e resina (MS Coat). A mensuração da condutibilidade foi novamente realizada após os discos permanecerem estocados em água destilada a $37^{\circ} \mathrm{C}$ durante um mês. Os resultados demonstraram que os 3 agentes dessensibilizantes diminuíram a condutibilidade hidráulica da dentina em torno de $60-65 \%$.

PEACOCK; ORCHARDSON ${ }^{98}$, em 1999, avaliaram a capacidade de soluções à base de sais de potássio (citrato de potássio, tartarato de potássio e oxalato de potássio) de bloquear o potencial de ação neural e comparar os resultados com soluções de cloreto de potássio e nitrato de potássio. As soluções 
testadas foram aplicadas ao nervo espinal de ratos e monitoradas enquanto eram estimulados eletricamente. Os autores concluíram que o citrato de potássio e o tartarato de potássio foram mais eficazs que os outros sais de potássio no bloqueio do potencial de ação neural, podendo ser utilizados como agentes dessensibilizantes dentinários.

GILLAM et al. ${ }^{45}$, em 1999, utilizaram o modelo de disco de dentina associado à microscopia eletrônica de varredura para avaliar a obliteração dos túbulos dentinários por agentes anti-hiperestésicos aplicados em consultório. Os discos de dentina foram obtidos a partir de molares hígidos, limpos com água destilada em ultrasom por 30 segundos. Antes da utilização dos cinco produtos a serem testados (Sensodyne Sealant, Butler Protect, Oxa-Gel, All-Bond 2 e OneStep), os quais foram aplicados seguindo-se as recomendações de cada fabricante, os discos foram condicionados com ácido cítrico a 6\% por 2 minutos, lavados com água destilada e colados em stubs metálicos. Os efeitos superficiais e a penetração nos túbulos foram observados no MEV. Os resultados demonstraram que, aparentemente, todos os agentes obliteraram os túbulos, embora o nível de cobertura e oclusão tenha variado entre os produtos. De todos os agentes sob teste, o produto à base de oxalato férrico (Sensodyne Sealant) apresentou melhores resultados, seguido dos produtos à base de primers resinosos. Aqueles à base de oxalato de potássio demostraram menor eficácia na obstrução dos túbulos dentinários, apesar de diminuírem o lúmen dos túbulos e apresentarem cristais no seu interior.

PASHLEY et al. ${ }^{97}$, em 2001, utilizaram um gel de oxalato de monopotássio monohidrogenado a 3\% sob restaurações adesivas em dentina exposta para 
avaliar se o uso combinado desses agentes seria eficaz na redução da permeabilidade sem comprometer a força adesiva. Foram utilizados 8 discos de dentina de $0,5 \mathrm{~mm}$ de espessura, os quais foram condicionados com ácido cítrico a $6 \%$ por 2 minutos no lado do esmalte onde havia smear layer. A permeabilidade da dentina foi determinada pela filtração de fluidos através dos discos, e expressada em condutibilidade hidráulica. Os discos foram tratados com oxalato por 2 minutos, e uma coroa de resina foi confeccionada, seguindo-se os procedimentos adesivos. Após 24 horas, os discos foram seccionados e preparados para o teste de tração. O MEV foi utilizado para observar os efeitos do tratamento na superfície e no interior dos túbulos dentinários, além da interface adesiva. Os resultados demonstraram que o oxalato de potássio diminuiu a condutibilidade hidráulica dos discos de dentina. As imagens do MEV revelaram a formação de cristais de oxalato de cálcio na superfície e no interior dos túbulos dentinários. Esses cristais não comprometeram a formação da camada híbrida na superfície dentinária, pois o monômero preencheu os espaços entre os cristais, formando tags.

GILLAM et al. ${ }^{46}$, em 2001, utilizaram o MEV para avaliar o efeito de produtos à base de oxalato de potássio na superfície da dentina exposta. Os discos de dentina foram obtidos a partir de molares hígidos, limpos com água destilada em ultrasom por 30 segundos, e o ácido cítrico a 6\% foi aplicado por 2 minutos. Os produtos utilizados foram: Butler Protect, MS Coat, Sensodyne Sealant e Tenure Quick). Os resultados demonstraram que o Butler Protect não recobriu a superfície totalmente, mas determinou algum grau de obstrução, ao contrário dos outros produtos que foram totalmente eficazes. 
Uma revisão de literatura, realizada por SENA ${ }^{114}$, em 1990, sobre os agentes terapêuticos utilizados para o tratamento da hipersensibilidade dentinária, confirma a importância dos testes laboratoriais para um melhor entendimento do assunto. A preferência de modelos laboratoriais no estudo da hipersensibilidade dentinária deve-se a alguns fatores, tais como dificuldade do manejo clínico, problemas na seleção de pacientes e diagnóstico e, ainda, a grande resposta do efeito placebo com referência à dor.

\section{Estudos Clínicos}

Produtos como dentifrícios, géis e enxaguatórios bucais têm sido clinicamente testados com a finalidade de aliviar o desconforto causado pela hiperestesia dentinária. Os resultados desses estudos clínicos variam muito: alguns são inconclusivos devido à diversidade de metodologias utilizadas, à variabilidade de respostas subjetivas, à influência do efeito placebo ${ }^{43} \mathrm{e}$, ainda, à natureza subjetiva da mensuração da dor ${ }^{126}$.

Nos estudos clínicos que têm por objetivo avaliar tratamentos para a hiperestesia dentinária, incluem-se, com freqüência, os dentifrícios. Esses estudos, apesar de utilizarem o mesmo método de mensuração de resposta ao tratamento (quanto ao estímulo e mensuração do grau de sensibilidade), possuem uma metodologia própria, já que a aplicação do agente anti-hiperestésico é realizada pelo próprio paciente em casa (delivery system), e não pelo cirurgiãodentista em consultório.

A literatura revisada a seguir focaliza os estudos de avaliação clínica nos quais foram utilizados produtos que atuam por obliteração dos canalículos dentinários, sejam estes por delivery system ou os aplicados pelo profissional em consultório odontológico. 
JENSEN; DOERING ${ }^{59}$, em 1987, realizaram um estudo comparativo entre uma solução anti-hiperestésica contendo fluoreto de sódio e cloreto de estrôncio com um agente adesivo fotopolimerizável, o qual não requeria que a smear layer fosse removida e nem que houvesse a penetração nos túbulos para sua retenção. Foram selecionados 38 pacientes com uma média de 3,2 dentes pré-molares ou anteriores com hiperestesia dentinária. A avaliação do grau de sensibilidade foi realizada a partir de uma escala verbal de 0 a 3, utilizando-se como estímulo uma sonda exploradora afiada e jato de ar em temperatura ambiente. Cada paciente recebeu dois tratamentos: o primeiro, consistiu na aplicação de uma solução de fluoreto de sódio a $0,42 \%$ e cloreto de estrôncio a 3,96\%, a qual foi aplicada ativamente por 3 minutos após profilaxia e secagem do dente, sendo os excessos removidos com um algodão. No segundo tratamento, o adesivo fotopolimerizável Scotchbond foi aplicado após os dentes terem recebido o mesmo tratamento do grupo anterior. Os pacientes foram reavaliados 3 e 6 meses depois. Os resultados demonstraram que o adesivo Scotchbond foi o mais eficaz na redução da hiperestesia dentinária.

ORCHARDSON; COLLINS ${ }^{83}$, em 1987, avaliaram 109 pacientes com sintomas de hiperestesia dentinária. Esses pacientes foram questionados sobre a duração, localização e como ocorria a dor, além do tipo de escova e dentifrício utilizados. O grau de sensibilidade foi mensurado através de estímulos mecânicos (sonda e jato de ar), os quais, segundo os mesmos autores, são testes reproduzíveis. Nesse estudo, a maioria dos pacientes relatou que o jato de ar, tanto sozinho como em combinação com outro estímulo, causou o maior desconforto. 
MUZZIN; JOHNSON ${ }^{82}$, em 1989, compararam os efeitos individual e combinado do oxalato de dipotássio a $30 \%$ e do oxalato monopotássio monohidrogenado a 3\% na redução da hiperestesia dentinária in vivo. Selecionaram-se 17 pacientes, cada um com 4 dentes hiperestésicos, num total de 68 faces vestibulares, que foram divididas em 4 grupos. Cada paciente recebeu os quatro tratamentos, sendo um tratamento por dente. Grupo 1: água destilada seguida de oxalato de dipotássio a 30\%; Grupo 2: água destilada seguida de oxalato monopotássio-monohidrogenado a 3\%; Grupo 3: oxalato de dipotássio a $30 \%$ seguido de oxalato monopotássio-monohidrogenado a $3 \%$; Grupo 4 (controle) : água destilada seguida de água destilada. Para mensurar as respostas (sim ou não), foi utilizado um teste térmico (frio) com água em diferentes temperaturas $\left(20^{\circ} \mathrm{C}, 15^{\circ} \mathrm{C}, 10^{\circ} \mathrm{C}, 5^{\circ} \mathrm{C}\right.$ e $10^{\circ} \mathrm{C}$, com uma variação de $\pm 1^{\circ} \mathrm{C}$ para cada intervalo de temperatura). Para cada dente testado, registrou-se a temperatura que resultava em uma resposta sensitiva. Além da avaliação antes da aplicação das substância e imediatamente depois, foram realizadas avaliações após 1, 2 e 4 semanas. Os resultados demonstraram uma significativa redução da hiperestesia dentinária nas avaliações imediata e após 4 semanas quando comparadas ao baseline nos dentes tratados com água destilada seguida de oxalato monopotássio-monohidrogenado a 3\% (Grupo 2). Para esse mesmo grupo, não houve diferença estatisticamente significante quando se compararam os dados do baseline com os resultados obtidos após 1 ou 2 semanas. Alcançaram-se os melhores resultados no Grupo 3 (oxalato de dipotássio a 30\% seguido de oxalato monopotássio-monohidrogenado a 3\%), no qual uma redução de grande significância estatística foi observada em 1 e 2 semanas após o tratamento. 
COOLEY; SANDOVAL ${ }^{24}$, em 1989, avaliaram a eficácia do oxalato de potássio na redução da sensibilidade dentinária. Participaram deste estudo clínico 28 pacientes com dentes sensíveis (e sem cárie ou cálculo) em duas diferentes áreas da boca. Para a avaliação do grau de sensibilidade, foi utilizada uma escala verbal de 0 a 5 com a finalidade de obter-se uma melhor distribuição das respostas. Após isolamento relativo, um dente foi tratado com água destilada e o outro, com oxalato de potássio monohidrogenado, sendo cada agente aplicado por 2 minutos. Imediatamente após o tratamento, os pacientes fizeram o teste de sensibilidade ingerindo um copo com água gelada $\left(10^{\circ} \mathrm{C}\right)$, e o questionário foi novamente aplicado. Esse tratamento foi repetido no intervalo de 1 semana, 1 mês e 3 meses. Os resultados indicaram que, após a aplicação dos agentes, ambos os tratamentos obtiveram uma redução estatisticamente significante na sensibilidade. A sensibilidade dos dentes tratados com água destilada permaneceu constante nos 3 tempos avaliados. Por outro lado, a sensibilidade dos dentes tratados com oxalato de potássio-monohidrogenado aumentou progressivamente no mesmo período, tanto que, ao final de 3 meses, não houve diferença estatística entre os valores obtidos antes do tratamento. O resultado que se obteve com o uso da água destilada pode ser atribuído ao efeito placebo e a fatores psicogênicos, que devem ser considerados em estudos que envolvem a dor.

KERNS et al. ${ }^{61}$, em 1991, avaliaram clinicamente a obliteração dos túbulos através de procedimentos clínicos como raspagem e alisamento radicular e aplicação de soluções de oxalato de potássio, utilizando, como controle, dentes tratados com EDTA. Para tanto, foi desenvolvido um modelo de avaliação in vivo. Foram realizados cortes de $2 \mathrm{~mm} \times 3 \mathrm{~mm}$ imediatamente abaixo da junção amelo- 
dentinária em dentes extraídos. Após os diferentes tratamentos, esses fragmentos foram incorporados a uma prótese parcial removível, que foi instalada no próprio doador do dente. Feitas as avaliações no MEV, os resultados demonstraram que, após 7 dias, os dentes tratados com oxalato de potássio apresentaram poucos cristais, e os túbulos estavam abertos. Após 4 semanas, o diâmetro dos túbulos tratados com oxalato de potássio diminuiu significativamente. Os autores concluíram que a criação de smear layer ou a aplicação de oxalatos, tendo em vista a oclusão dos túbulos dentinários, são procedimentos de curta duração, mas que podem oferecer um conforto ao paciente até que ocorra a obliteração natural dos túbulos dentinários.

OYAMA; MATSUMOTO ${ }^{86}$, em 1991, realizaram um estudo clínico para avaliar a correlação entre a morfologia superficial dos túbulos dentinários e a hiperestesia. Foram examinados 105 incisivos e molares de pacientes com hiperestesia dentinária. Feitas as réplicas da dentina cervical, a superfície dos dentes foi secada com algodão e, posteriormente, lavada por 3 minutos, alternando-se esponjas embebidas em álcool a $70 \%$ e solução de hipoclorito a $5 \%$. Por fim, as áreas afetadas foram lavadas com água destilada e secadas com jatos de ar. O grau de sensibilidade dentinária foi medido através de uma Escala de Medida Verbal (EMV) de 0 a 3, utilizando-se o jato de ar como estímulo. A dentina cervical hiperestésica foi examinada tanto com uma sonda exploradora, que foi passada cuidadosamente, e através de um estímulo elétrico. As áreas hiperestésicas foram, então, fotografadas e comparadas com as réplicas. Os resultados mostraram uma correlação estatisticamente significante entre a morfologia dos túbulos dentinários e a hiperestesia dentinária. 
CUENIN et al. ${ }^{26}$, em 1991, investigaram a relação entre a hiperestesia dentinária e a abertura dos túbulos dentinários in vivo em dentes a serem extraídos. A hiperestesia foi diagnosticada em 20 pacientes adultos através da utilização de uma escala de sensibilidade de 0 a 4 . A superfície dentinária foi condicionada com EDTA a fim de remover a smear layer e expor os túbulos dentinários, e, então, tratada com oxalato de monopotássio monohidratado a 3\% ou uma solução de cloreto de sódio a 3\%. Avaliou-se a sensibilidade ao jato de ar antes e depois do tratamento. Os pacientes foram anestesiados e os dentes extraídos. Os espécimes foram seccionados, colados em stubs, secados ao ponto crítico, metalizados e observados no MEV. O grau de abertura dos túbulos foi comparado com o grau de sensibilidade indicado pelo paciente durante a utilização do estímulo ar. Os resultados demonstraram que os túbulos dentinários após o tratamento com EDTA tinham abertura em torno de $1720 \mathrm{~mm}$. A abertura diminuiu para $0.564 \mathrm{~mm}$ após o tratamento com o oxalato de potássio, e para 0.386 após a aplicação do cloreto de sódio. Os autores concluíram que uma solução de cloretos de sódio com pH baixo pode ser um tratamento eficaz da hiperestesia dentinária após cirurgia periodontal ou em pacientes com recessão gengival.

HOLBOROW ${ }^{55}$, em 1994, avaliou a eficácia de uma solução comercial antihiperestésica de oxalato monopotássio-monohidrogenado a 3\% (Butler Protect), utilizando como controle água contendo um corante similar. Foram selecionados 30 pacientes com dois dentes hiperestésicos. Cada dente foi testado com sonda exploradora e água gelada, e o grau de sensibilidade foi mensurado em uma Escala de Medida Verbal de 0 a 3 . Cada paciente recebeu as 2 soluções, e realizaram-se avaliações imediatamente após as aplicações e 7, 14 e 28 dias 
depois. Os resultados demonstraram que não houve diferença estatisticamente significante entre os grupos controle e experimental em qualquer etapa da avaliação. Quando a sonda foi utilizada como estímulo, os resultados foram semelhantes, ao passo que, com o estímulo frio, houve uma diferença estatisticamente significante na redução da hiperestesia dentinária quanto ao uso da solução experimental no $28^{\circ}$ dia. $O$ autor concluiu que, para a sensibilidade ao frio, o oxalato de monopotássio monohidrogenado é eficaz e que, para o estímulo sonda, os resultados são inconclusivos devido à dificuldade de localizar precisamente a mesma área hiperestésica da superfície radicular nos diferentes períodos.

PEARCE; ADDY; NEWCOMBE ${ }^{99}$, em 1994, compararam clinicamente a eficácia de 3 dentifrícios: 2 anti-hiperestésicos contendo sal de estrôncio e outro fluoretado. Um total de 119 pacientes completaram o tratamento. O grau de sensibilidade foi obtido no baseline e após 1, 4, 8 e 12 semanas. Foram utilizados como estímulos o jato de ar aplicado com a seringa tríplice por 3 segundos a 3 $\mathrm{mm}$ da dentina exposta, uma sonda termoelétrica a $0^{\circ} \mathrm{C}$ e, ainda, uma sonda clínica, que foi passada horizontalmente sobre a dentina exposta. O grau de sensibilidade foi mensurado de duas maneiras: através da Escala de Medida Verbal (EMV) de 0 a 3, e após a aplicação de cada estímulo individualmente, o grau de sensibilidade foi novamente mensurado, utilizando-se, agora, a Escala Analógica Verbal (EAV) de 0 a 10. Os resultados desse estudo demonstraram que os dois dentifrícios contendo estrôncio apresentaram redução semelhante, a qual não se mostrou maior do que aquela observada em relação ao dentifrício convencional fluoretado. 
SILVERMAN; GINGOLD; CURRO ${ }^{116}$, em 1994, compararam, em 62 pacientes, a eficácia de um dentifrício comercial contendo 3,75\% de cloreto de potássio e 0,8\% de monofluorfosfato de sódio (Sensodyne) com outro dentifrício contendo apenas cloreto de potássio. Um dentifrício placebo, que continha todos os ingredientes, com exceção do cloreto de potássio e do monofluorfosfato de sódio foi também usado. Após a utilização da sonda exploradora e o jato de ar (a $19-21^{\circ} \mathrm{C}$ por 1 segundo), fez-se a avaliação do grau de sensibilidade de acordo com a EMV de 0 a 3 no baseline e após 2, 4, e 8 semanas. Os resultados demonstraram que os dentifrícios contendo cloreto de potássio com ou sem monofluorfosfato de sódio reduziram significativamente a hiperestesia dentinária sujeita aos estímulos táctil e jato de ar.

PEREIRA et al. ${ }^{102}$, em 1994, desenvolveram um estudo envolvendo o tratamento da hiperestesia dentinária em 28 pacientes submetidos a procedimento periodontal. O grau de sensibilidade foi avaliado através da utilização de sonda exploradora e jato de ar/água e mensurado através de uma Escala de Medida Verbal, sendo 0 - ausência de dor, 1 - dor mínima, 2 - dor moderada e 3 - dor intensa por mais de 10 segundos. Cento e quarenta dentes foram tratados com oxalato de potássio $\left(\mathrm{Oxa}-\mathrm{Gel} \mathrm{I}^{\circledR}\right)$ e sob isolamento relativo por um período de 4 semanas. Como controle, utilizou-se um placebo em 82 dentes nas mesmas condições e período. A hiperestesia dentinária foi avaliada antes e imediatamente após a aplicação do agente anti-hiperestésico em cada semana. Após aquele período, os dentes que ainda se apresentavam hiperestésicos foram novamente tratados. Os resultados indicaram que, após 4 semanas de tratamento com o Oxa-Gel ${ }^{\circledR}$, uma redução significativa da hiperestesia foi observada, pois 88,5\% dos dentes apresentaram ausência de dor ou dor mínima. Os resultados 
com o placebo foram semelhantes (76,8\%). Após 6 meses, foram avaliados $94,5 \%$ dos dentes, os quais mantiveram baixos índices de hiperestesia. Após 8 meses, quando 47 dentes foram reavaliados, verificou-se que ainda baixos índices de sensibilidade.

YAMAMOTO, H. et al. ${ }^{130}$, em 1995 , examinaram a posição dos cristais precipitados após o tratamento com oxalato de potássio em dentina exposta de cães in vivo. A estabilidade dos cristais também foi avaliada por meio de exame da superfície tratada e dos túbulos após uma semana de exposição ao ambiente oral. A dentina foi exposta com a utilização de brocas e, após o condicionamento ácido, a superfície foi tratada com oxalato de dipotássio a $30 \%$, seguido de oxalato monohidrogenado a 3\%. Após o tratamento com o oxalato, numerosos cristais foram encontrados tanto na superfície como no interior dos túbulos (100um). A densidade dos cristais na superfície dentinária e no interior dos túbulos foi diminuindo após 1 semana de exposição à cavidade oral. A dentina estava coberta com smear layer, mas muitos túbulos dentinários estavam abertos e ampliados, e cristais foram encontrados nas porções mais profundas dos túbulos. Os resultados indicam que a precipitação de cristais de oxalato in vivo ocorre não somente na superfície dentinária, como também no interior dos túbulos, e que a precipitação de cristais no interior dos túbulos ocorreu somente quando a smear layer foi removida por ácidos.

Com o objetivo de investigar a redução da hiperestesia dentinária em 50 indivíduos por um período de 6 semanas, GILLAM et al. ${ }^{44}$, em 1996, compararam a eficácia de 2 enxaguatórios bucais: um, contendo nitrato de potássio, sílica e fluoreto de sódio, e outro, apenas sílica e fluoreto de sódio. Os estímulos 
utilizados foram a sonda de Yeaple e o jato de ar (a $19 \pm 3^{\circ} \mathrm{C}$ por 1 segundo), sendo o grau de sensibilidade mensurado através da Escala Analógica Verbal (EAV) de 0 a 10 . Os resultados demonstraram que o enxaguatório contendo nitrato de potássio a $3 \% /$ sílica/fluoreto de sódio apresentou uma redução significativa da hiperestesia dentinária quando foram utilizados os estímulos táctil e térmico.

ESTRELA, C. et al. ${ }^{34}$, em 1996, realizaram um estudo com 160 dentes (caninos e pré-molares) portadores de hipersensibilidade dentinária observada após tratamento periodontal. Cada produto testado foi aplicado em 20 dentes com diferentes graus de hiperestesia. As avaliações foram feitas no período de 7, 15, 30 e 60 dias, sendo a sonda exploradora (estímulo táctil) usada com a mesma pressão pelo mesmo avaliador; e estímulo térmico (teste da água fria e do jato de ar). A mensuração do grau de hiperestesia foi realizada através da Escala de Medida Verbal de 0 a 3 . No Grupo 1, utilizou-se água destilada como agente placebo, aplicando-a com bolinhas de algodão por 2 min.. No Grupo 2, o fluoreto de sódio foi aplicado por $5 \mathrm{~min}$, sendo que, no primeiro minuto, fez-se brunidura com o auxílio de uma taça de borracha. No Grupo 3, aplicou-se a pasta de hidróxido de cálcio com água destilada, seguindo o mesmo critério do Grupo 2. Nos Grupos 4 e 5, foram aplicados Oxa-gel ${ }^{\circledR}$ e Duraphat. Nos Grupos 6, 7, e 8, aplicaram-se os sistemas adesivos Scotchbond Multi-uso Plus, Optibond e Multibond Alpha respectivamente, empregando-se o ácido fosfórico a 37\% por 15 segundos para o condicionamento. Com exceção dos sistema adesivos, que foram utilizados apenas uma vez, os demais produtos foram novamente aplicados a cada período de observação. Os resultados indicaram que o hidróxido de cálcio e o fluoreto de sódio a $2 \%$ apresentaram os menores valores na redução da dor 
pós-tratamento para os 3 níveis de sensibilidade. O Duraphat e o sistema adesivo Multibond Alpha mostraram valores intermediários em todos os níveis de sensibilidade. Para o grau de sensibilidade 1, o sistema adesivo Optibond e o Oxa-gel ${ }^{\circledR}$ demonstraram os melhores valores de redução da dor $(88,8 \%$ e $87,5 \%$ respectivamente). Para os graus 2 e 3 de sensibilidade, o Oxa-Gel ${ }^{\circledR}$ e o sistema adesivo Scotchbond Multi-uso Plus mostraram os melhores resultados (sendo $87,5 \%$ e $75,0 \%$ para o grau 2 , e $75,0 \%$ e $75,0 \%$ para o grau 3 respectivamente). Pode-se notar a ocorrência de baixa redução de dor imediatamente após a aplicação dos sistemas adesivos para os 3 diferentes graus de sensibilidade, com melhora expressiva aos 30 dias. No Grupo 1 (controle), mesmo empregando um agente placebo (água destilada), verificou-se que, para o nível 1 de sensibilidade, a redução de dor pós-tratamento alcançou 40\% no período de 60 dias.

GILLAM et al. ${ }^{43}$, em 1997, compararam in vivo um adesivo (All-bond 2) e um produto à base de oxalato de potássio (Butler Protect) em 55 dentes, tendo cada um deles um outro dente sensível como controle. Os estímulos utilizados foram o táctil (sonda de Yeaple) e o jato de ar $\left(19\right.$ a $24^{\circ} \mathrm{C}$ a $1 \mathrm{~cm}$ e aplicado perpendicularmente); o grau de sensibilidade foi mensurados através da Escala Analógica Verbal (EAV) de 0 a 10, antes, depois de meio minuto e após 1, 2 e 3 meses. Os resultados demonstraram que houve uma tendência à diminuição da hiperestesia dentinária para todos os grupos, mas nenhuma diferença estatisticamente significante foi observada entre os grupos.

WEST et al. ${ }^{126}$, em 1997, compararam clinicamente três produtos em 112 pacientes: um dentifrício anti-hiperestésico à base de estrôncio e outro à base de potássio, ambos contendo flúor, e um dentifrício convencional com flúor. Os 
estímulos utilizados foram táctil (sonda exploradora) por pressão relativamente constante, e jato de $\operatorname{ar}\left(17\right.$ a $21^{\circ} \mathrm{C}$, aplicado perpendicularmente por 3 segundos a 1-3mm do dente). O grau de sensibilidade foi mensurado através da Escala Analógica Verbal (EAV) de 0 a 10 no baseline e após 2 e 6 semanas. Embora os resultados tenham revelado uma diminuição da hiperestesia dentinária em todos os grupos, essa diminuição, porém, não foi estatisticamente significante entre os grupos em qualquer intervalo de tempo.

PLAGMANN, et al. ${ }^{104}$ em 1997 realizaram uma avaliação clínica de 8 semanas com vistas ao tratamento da hiperestesia dentinária. Para tanto, os autores compararam o desempenho de 2 dentifrícios (um contendo fluoreto de amina, e o outro, fluoreto de sódio) com o de dentifrício placebo. O grau de hiperestesia foi avaliado através de estímulos táctil (sonda de Yeaple) e evaporativo (jato de ar com temperatura entre 19 e $21^{\circ} \mathrm{C}$, aplicado por 1 segundo), e mensurado de acordo com a Escala Verbal Analógica (de 0 a 10) e, ainda, a resposta pessoal do paciente. Os 3 grupos apresentaram graus de sensibilidade semelhantes no baseline. Os resultados demonstraram que os dentifrícios são eficazes na diminuição da hiperestesia dentinária, mas seu desempenho não difere estatisticamente daqueles obtidos com o uso do dentifrício placebo.

Em 38 pacientes selecionados, YEATES et al. ${ }^{131}$, em 1998, avaliaram clinicamente a eficácia do fosfato de cálcio na obliteração dos túbulos dentinários utilizando um placebo como controle. Como estímulos, utilizaram a sonda exploradora (passada horizontalmente sobre a lesão, sob pressão controlada) e, após 5 minutos, o jato de ar (por 2 segundos, a $19^{\circ} \mathrm{C} \pm 5^{\circ} \mathrm{C}$ perpendicularmente a 1 
$\mathrm{cm}$ do dente) e também água gelada $\left(\mathrm{a} 10^{\circ} \mathrm{C}\right.$ e $\left.0^{\circ} \mathrm{C}\right) . \mathrm{O}$ grau de sensibilidade foi mensurado através da Escala Analógica Verbal (0 a 10) no baseline e após 2, 7, $14,21,28,56$ e 84 dias. Os resultados demonstraram que houve uma diminuição considerável da hiperestesia, mas não se observou uma diferença estatisticamente significante entre os materiais. Os autores concluíram que, ou o fosfato de cálcio não teve efeito terapêutico, ou o efeito foi mascarado pelo placebo.

CARVALHO; DIAS ${ }^{19}$, em 1999, avaliaram a eficácia de três substâncias (flúor gel tópico acidulado Sultan; Oxa-Gel ${ }^{\circledR}$ e Arnica a 35\% em Orobase) no tratamento da hiperestesia dentinária cervical. Foram selecionados 45 pacientes que, na primeira consulta, receberam instruções de higiene bucal, profilaxia e tiveram a hiperestesia dentinária avaliada. As soluções foram reaplicadas a cada 7 dias, durante 4 semanas. A hiperestesia dentinária foi avaliada após 30 e 60 dias. Os resultados indicaram que não houve diferença estatisticamente significante entre a Arnica e o Oxa-Ge ${ }^{\circledR}$, os agentes mais eficazes no tratamento da hiperestesia dentinária do que o flúor.

MORRIS; DAVIS; RICHARDSON ${ }^{81}$, em 1999, compararam o efeito clínico de 2 agentes dessensibilizantes em pacientes com hiperestesia dentinária. Um dos agentes testados foi à base de oxalato de potássio em solução resinosa (Pain Free), e o outro à base de flúor (DentinBloc), tendo um placebo (água destilada) como controle. Selecionaram-se pacientes que deveriam, obrigatoriamente, apresentar 3 dentes com sensibilidade, os quais foram tratados com os 2 agentes e, também com o placebo. O grau de sensibilidade foi mensurado segundo a Escala Visual Analógica (EAV), usando-se, antes e após os tratamentos, sonda 
clínica e jato de ar como estímulos. O grau de sensibilidade foi novamente mensurado após 1 semana, 1 e 3 meses. Os resultados demonstraram que todos os agentes, inclusive o placebo, reduziram a sensibilidade dentinária, não ocorrendo diferença estatisticamente significante entre eles.

MARTINELI ${ }^{74}$, em 1999, avaliou as respostas imediata e mediata de 94 dentes (caninos e pré-molares), que apresentavam algum grau de sensibilidade dentinária (1, 2 ou 3) de acordo com a Escala de Medida Verbal (EMV) aos estímulos sonda e ar, após a aplicação de três formulações à base de oxalato de potássio: Oxa-Gel ${ }^{\circledR}$, Solução Experimental 1 e Solução Experimental 2, tendo um placebo como controle. Cada formulação de oxalato de potássio e o placebo foram aplicados passivamente por 3 minutos na superfície da dentina úmida, sendo o excesso de material removido posteriormente. O grau de sensibilidade foi avaliado antes (baseline) e imediatamente após a aplicação de cada formulação com um intervalo de 7 dias. Os resultados obtidos após a quarta aplicação foram denominados resultados imediatos e, após 6 meses, resultados mediatos. Os escores foram submetidos à análise estatística através dos testes de Kruskal-Wallis e de Friedman two-way ANOVA $(p<0,05)$. A aplicação de todos os materiais, inclusive o placebo, independente do tempo avaliado e dos estímulos utilizados, resultou em uma redução estatisticamente significante na hiperestesia dentinária podendo essa redução prolongar-se até seis meses. Houve uma tendência de respostas mais severas ao estímulo ar quando comparado ao estímulo sonda antes do tratamento, sendo que a hiperestesia provocada pela sonda se mostrou mais persistente ao longo do tratamento. $\mathrm{O}$ tratamento da hiperestesia dentinária está sujeito a variáveis clínicas que podem aumentar ou diminuir o efeito anti-hiperestésico dos agentes estudados. 
Em continuação ao estudo anterior, MARTINELI; PEREIRA ${ }^{75}$, em 2000, realizaram a avaliação desses pacientes após 1 ano, quando o grau de sensibilidade relatado pelos pacientes permaneceu baixo mesmo após esse período. 


\section{PROPOSIÇÃO}




\section{PROPOSIÇÃO}

O presente trabalho teve como objetivos:

1. Avaliar, in vitro e in vivo, a capacidade de reprodução da superfície dentinária por meio da técnica de réplica, utilizando-se um polivinilsiloxano hidrófilo de consistência ultra-leve (Aquasil ULV, Dentsply) e uma resina epóxica (Araldite - Ciba).

2. Analisar, in vitro e in vivo, através da técnica de réplica, o efeito do oxalato de potássio (Oxa-Gel ${ }^{\circledast}$ - Art-Dent, Brasil) sobre a superfície da dentina hiperestésica.

3. Analisar, in vivo, através da técnica de réplica, as características superficiais da dentina hiperestésica.

4. Analisar, in vivo, através da técnica de réplica, as possíveis modificações superficiais na dentina hiperestésica em um determinado período de tempo, sem qualquer tratamento.

5. Correlacionar, in vivo, as características superficiais da dentina quanto à presença de túbulos dentinários com o grau de sensibilidade relatado pelo paciente em diferentes situações clínicas. 


\section{MATERIAL E MÉTODO}

\subsection{ESTUDO IN VITRO}

A fim de avaliar a metodologia para obtenção de réplicas e possibilitar a comparação dos espécimes originais com as réplicas negativas e positivas, o presente trabalho foi realizado primeiramente in vitro.

\section{Seleção dos Dentes e Obtenção dos Discos de Dentina}

Foram selecionados 3 terceiros molares hígidos recém-extraídos, os quais, após serem devidamente limpos, permaneceram armazenados em solução de timol a 1\% com o propósito de prevenir a contaminação por bactérias até que se obtivessem os espécimes.

Cada dente foi fixado com cera pegajosa a um dispositivo e adaptado a uma máquina de corte (LABCUT 1010 EXTEC). A porção coronária de cada um dos dentes foi seccionada transversalmente com disco de diamante (XL 12205EXTEC) em baixa velocidade e sob abundante irrigação, acima da projeção dos cornos pulpares e abaixo da junção amelo-dentinária, retirando-se, de cada dente, somente um disco de dentina com aproximadamente $1 \mathrm{~mm}$ de espessura. Dessa forma, os discos eram compostos somente por dentina na região central, circundados por esmalte na periferia, totalizando três discos. Por meio de da observação em lupa estereoscópica com 40X de aumento, verificou-se a completa remoção de esmalte ou de remanescentes pulpares ${ }^{21}$. Com vistas a simulação e obtenção da smear layer, foi utilizada uma lixa de carbureto de tungstênio de granulação 600 , por 5 segundos, no lado oclusal de cada um dos discos. 


\section{Tratamento dos Discos de Dentina}

Cada disco de dentina foi dividido utilizando-se um cinzél para demarcação de duas linhas cruzadas, formando, então, quatro quadrantes, que foram numerados de 1 a 4 no sentido horário. Em seguida, os quadrantes 2, 3 e 4 de cada disco foram submetidos ao condicionamento com ácido cítrico a $6 \%$ líquido por 1 minuto em ambos os lados e lavados com água destilada, com a finalidade de expor os túbulos dentinários e simular a dentina hiperestésica, seguindo o modelo experimental proposto por PASHLEY; KALATHOOR; BURNHAM ${ }^{94}$, em 1986, GILLAM; MORDAN; NEWMAN², em 1997, GILLAM et al. ${ }^{45}$, em 1999 e PASHLEY et al. $^{97}$, em 2001. A smear layer foi mantida no quadrante 1, considerado o controle para a dentina não exposta.

Os quadrantes 3 e 4 restantes foram submetidos ao tratamento com o agente anti-hiperestésico à base de oxalato de potássio monohidratado a $3 \%$ $\left(O x a-G e l^{\circledR}\right.$ - Art-Dent Indústria e Comércio Ltda. São Paulo, Brasil), o qual foi aplicado passivamente por 3 minutos sobre a dentina ligeiramente úmida, e também ligeiramente lavado e secado com jatos de ar.

O tratamento da superfície dos discos de dentina foi realizado no sentido horário a partir do primeiro quadrante, identificado por uma marca em dentina feita com ponta diamantada esférica 1014 (KG SORENSEN Indústria e Comércio Ltda., Barueri - SP). O procedimento de dividir-se cada disco de dentina em quatro partes possibilitou a observação das diferentes condições préestabelecidas em uma única amostra, diminuindo-se, assim, tanto o número de moldagens como o de espécimes.

No quadrante 4 de cada disco fez-se a aplicação de ácido cítrico a 6\%, pH 2, por 1 minuto, submetendo o agente ao desafio ácido, à semelhança do que 
ocorreria na boca durante a ingestão de alimentos dessa natureza, a fim de avaliar a resistência a um meio ácido do agente anti-hiperestésico quanto ao efeito oclusivo. Os discos foram lavados por 15 segundos com água destilada. Cada um dos discos foi cuidadosamente secado com leves jatos de ar antes de realizar-se a moldagem da superfície, a qual foi executada imediatamente após o tratamento.

\section{Moldagem e Obtenção das Réplicas}

O material de impressão utilizado foi uma silicona de adição de consistência ultra-leve (AQUASIL ULV - Dentsply), manipulada de acordo com as recomendações do fabricante e dispensada em pequena quantidade em forma de gota sobre uma placa de vidro. Sobre essa gota de silicona, deitou-se cuidadosamente cada um dos discos de dentina, com a superfície tratada voltada para o material de moldagem, realizando-se uma leve pressão até que o disco se acomodasse sobre o mesmo. Seis minutos depois, removeram-se os discos de dentina do molde.

Após 24 horas, uma resina epóxica de baixa viscosidade (ARALDITE GY 1109 BR - Ciba) foi proporcionada conforme as especificações do fabricante e de tal modo que apresentasse uma consistência que permitisse o escoamento sobre o molde, ou seja:
Araldite
GY 1109 BR - 100 ----- 5,0 g
Endurecedor
GY 830 BR - 45 ------ 2,25 g
Endurecedor
GY 850 BR - 15 ----- $0,75 \mathrm{~g}$
O molde foi previamente limpo com jatos de ar a fim de evitar a formação de bolhas. 
Posteriormente ao endurecimento da resina, o que ocorreu em 24 horas, esta foi cuidadosamente removida do molde, identificada e armazenada.

Os discos de dentina, desidratados em estufa por 24 horas a $36-40^{\circ} \mathrm{C}$, e seus respectivos moldes e réplicas foram colados em stubs metálicos, recobertos com ouro no metalizador HUMMER VII (Alexandria, USA), com $30 \mathrm{~nm}$ de espessura e observados no Microscópio Eletrônico de Varredura (ZEISS DSM 940 A - Germany, com aumento de 1000X), permitindo a comparação entre os mesmos. Para a análise de cada espécime (disco, molde e réplica positiva) no MEV, o centro de cada quadrante foi escolhido como a região de onde as imagens deveriam ser observadas.

\subsection{ESTUDO IN VIVO}

A segunda parte da pesquisa teve como objetivo avaliar o potencial de reprodução da superfície dentinária hiperestésica in vivo através da observação das réplicas negativas e positivas, antes e após o tratamento com o agente dessensibilizante, e, se possível, correlacionar as características dessa superfície com o grau de sensibilidade descrito pelo paciente.

\section{Comitê de Ética em Pesquisa}

É importante salientar que esse estudo clínico foi submetido à análise pelo Comitê de Ética em Pesquisa com Seres Humanos da Faculdade de Odontologia de Bauru - USP, tendo sido aprovado em 14 de março de 2001, conforme documento apresentado (ANEXO 1). Os pacientes dessa pesquisa foram selecionados entre funcionários do Hospital de Clínicas e Faculdade de Medicina de Marília - FAMEMA, cujo Comitê de Ética em Pesquisa Envolvendo Seres Humanos procedeu à avaliação do projeto e decidiu pela sua aprovação em 
reunião de 14 de abril de 2001, conforme o protocolo $n^{0} 123 / 01$, de 19 de abril de 2001 (ANEXO 2).

\section{Seleção dos Pacientes}

Os 12 pacientes participantes da pesquisa foram selecionados a partir dos seguintes critérios ${ }^{81}$ :

- pacientes que apresentavam lesões cervicais não cariosas com sensibilidade em dentes posteriores (pré-molares) e/ou anteriores (caninos);

- $\quad$ pacientes sem registro de doenças sistêmicas e psicológicas graves;

- pacientes com saúde bucal em condições de permitir um diagnóstico correto da hiperestesia dentinária;

- pacientes que tinham interesse no tratamento dessa sensibilidade e que se dispuseram a realizá-lo;

- pacientes que se manifestaram de acordo com os métodos utilizados na pesquisa, conforme os princípios éticos recomendados pelo Comitê de Ética em Pesquisa com Seres Humanos da Faculdade de Odontologia de Bauru - USP.

Em uma primeira consulta, os pacientes foram entrevistados e examinados para verificação da condição bucal e dos dentes que poderiam ser utilizados na investigação. Os pacientes foram informados do propósito da pesquisa e do método a ser utilizado por meio da CARTA DE INFORMAÇÃO AO PACIENTE (ANEXO 3) e, estando cientes e de acordo, assinaram um TERMO DE CONSENTIMENTO LIVRE E ESCLARECIDO (ANEXO 4), o qual consiste em uma autorização do próprio paciente para participar na pesquisa clínica e submeter-se à execução do tratamento. 
Juntamente com o preenchimento da FICHA DE IDENTIFICAÇÃO DO PACIENTE (ANEXO 5), aplicou-se um questionário anamnético para registro das condições sistêmicas e comportamentais, com a finalidade de diagnosticar a provável etiologia da hiperestesia dentinária, descartando-se, assim, a possibilidade de a sensibilidade ser proveniente de outras situações clínicas. Além dos dados pessoais, foi considerado o relato do paciente em relação à hiperestesia dentinária, por meio do qual obtiveram-se informações sobre a etiologia e intensidade da dor. No caso de persistir alguma dúvida quanto ao correto diagnóstico da hiperestesia, um exame radiográfico foi indicado.

\section{Seleção dos Dentes}

Foram selecionados 23 dentes que apresentavam lesões cervicais não cariosas hiperestésicas, conforme os critérios propostos por KAUFMAN; KLEINBERG ${ }^{60}$, em 1994, GILLAM et al. ${ }^{43}$, em 1997,e HOLLAND et al. ${ }^{56}$, em 1997.

1. Grupo dentário: caninos e pré-molares.

2. Padrão de higiene bucal: de regular para bom.

3. Condição geral do dente selecionado: não poderia apresentar cáries, trincas ou fraturas, restaurações extensas ou insatisfatórias, prótese ou aparelhos de contenção e incidência de forças oclusais anormais.

4. Condição periodontal: ausência de bolsas periodontais e mobilidade, bem como não ter sido submetido a cirurgia periodontal nos últimos 3 meses antecedentes ao exame clínico.

5. Características da lesão: lesão cervical não cariosa com sensibilidade.

6. Etiologia: as lesões foram selecionadas independentemente da etiologia (erosão, abrasão e/ou abfração). 
7. Tratamento anterior: o paciente não poderia ter utilizado nenhum agente dessensibilizante.

Depois que os dentes foram devidamente selecionados, realizaram-se os procedimentos clínicos.

\section{Determinação dos Padrões de Hiperestesia}

Cada dente selecionado recebeu dois estímulos: sonda exploradora (estímulo táctil) e jato de ar (térmico-evaporativo). A aplicação do estímulo sonda foi feita de maneira que a mesma percorresse toda a extensão da lesão, sob pressão controlada, após treinamento realizado pelo mesmo operador, até que o paciente relatasse dor semelhante à que o fez procurar por tratamento. Cinco minutos após a utilização da sonda, a dentina exposta recebeu o jato de ar com seringa tríplice a uma pressão de 80 libras por 1 segundo, à temperatura de aproximadamente $20^{\circ} \mathrm{C}$ e a uma distância de $1 \mathrm{~cm}$ do dente, sem promover $\mathrm{o}$ ressecamento da superfície dentinária. Todos os procedimentos foram realizados no mesmo consultório odontológico pelo mesmo operador, com a finalidade de padronizar a pressão e temperatura do jato de ar.

O grau de sensibilidade de cada dente foi avaliado utilizando-se a Escala Visual Analógica $(E V A)^{20}$, a qual consiste de uma linha horizontal com $10 \mathrm{~cm}$ de comprimento e cujas extremidades representam os limites da dor: ausência de desconforto (0) e desconforto severo (10), como demonstrado abaixo:

sem

desconforto desconforto

severo

No momento da aplicação dos estímulos, os pacientes foram questionados sobre a intensidade do desconforto provocada pelos estímulos. Em seguida, o 
próprio paciente fez uma marca vertical na linha, determinando, assim, um escore de sensibilidade, conforme os diferentes níveis descritos abaixo:
0 = sem desconforto
1 = quase imperceptível
2 = muito leve
3 =. Leve
4 = moderada
5 = levemente forte

6 = forte

7 = intensa

8 = muito intensa

9 = extremamente intensa

10 = desconforto severo

Esses dados foram registrados na FICHA DE CONTROLE (ANEXO 6).

Foram selecionados pacientes com diferentes graus de sensibilidade à EVA, já que o objetivo desse trabalho não foi avaliar a eficácia do agente antihiperestésico utilizado, mas sim tentar correlacionar as características superficiais da dentina com o grau de sensibilidade relatado pelo paciente antes e depois do tratamento. De qualquer modo, foram selecionados dentes com grau de sensibilidade mínimo correspondente a $3 \mathrm{~cm}$ ao estímulo sonda e/ou jato de ar, de acordo com a EVA, para serem considerados hiperestésicos.

Os dentes selecionados (caninos e pré-molares) foram divididos aleatoriamente em dois grupos, conforme mostra a Figura 4.1.

\begin{tabular}{|c|r|c|}
\hline GRUPO & \multicolumn{1}{|c|}{ MATERIAL } & DENTES (N) \\
\hline G 1 & Oxa-Gel ${ }^{\circledR} \quad$ (Art-Dent Ind. Com. Ltda., Brasil) & 16 \\
\hline G 2 & Sem tratamento & 07 \\
\hline & TOTAL DE DENTES & 23 \\
\hline
\end{tabular}

Figura 4.1: Distribuição dos dentes por grupos 
Técnica de Moldagem

Após a seleção dos dentes e a anotação dos escores de sensibilidade, foram feitas as moldagens para obtenção das réplicas, que determinaram, microscopicamente, os padrões dentinários antes do tratamento proposto.

Realizaram-se três moldagens consecutivas da mesma superfície: a primeira, para promover a limpeza da superfície, e que foi descartada; a segunda, para a obtenção de réplicas positivas de resina epóxica, e a terceira, para obtenção das réplicas negativas. Todas as moldagens foram igualmente efetuadas como se segue:

- $\quad$ isolamento relativo com afastador labial , roletes de algodão e sugador;

- $\quad$ limpeza da superfície dentinária, com algodão umedecido em hipoclorito de sódio a $1 \%^{2}$;

lavagem com água destilada e secagem com jato de ar;

preparo da silicona de adição ultra leve (Aquasil ULV - Dentsply), que foi manipulada de acordo com as especificações do fabricante, levada e acomodada sobre a superfície dentinária seca, sem pressão, com uma espátula número 24;

- $\quad$ espera de um período mínimo de 6 minutos antes da remoção do molde, conforme as especificações do fabricante;

armazenagem do molde por 24 horas, em local fechado, seco e limpo.

\section{GRUPO 1: OXALATO DE POTÁSSIO OXA-GEL ${ }^{\circledR}$ (Art-Dent, Brasil)}

O agente foi aplicado conforme as especificações do fabricante, ou seja:

a) isolamento relativo com roletes de algodão;

b) aplicação de bolinhas de algodão umedecidas em água sobre a dentina; 
c) secagem da dentina com papel absorvente, para que a mesma permanecesse úmida ${ }^{101}$;

d) aplicação passiva do produto por 3 minutos;

e) remoção dos excessos.

Foram realizadas quatro aplicações do agente dessensibilizante, com intervalo de 7 dias entre cada aplicação. Imediatamente após a quarta aplicação do agente antihiperestésico, o grau de sensibilidade foi reavaliado, utilizando-se os mesmos estímulos e a mesma escala (EVA), conforme já descrito.

Novas moldagens da superfície dentinária, agora tratada com o agente antihiperestésico, foram realizadas para observação e comparação das alterações superficiais que poderiam ocorrer após o tratamento. Nesse momento, realizaramse duas moldagens, sendo a primeira, para obtenção das réplicas de resina epóxica (réplicas positivas) e a segunda, para observação direta do molde (réplica negativa), seguindo-se os mesmos procedimentos descritos anteriormente (vide p.91). A moldagem de limpeza superficial não foi realizada para não remover o agente antihiperestésico da superfície.

\section{GRUPO 2: SEM TRATAMENTO}

Nesse grupo, nenhum agente antihiperestésico foi aplicado, pois a intenção foi apenas monitorar as possíveis alterações no grau de sensibilidade após um período de quatro semanas, e observar a ocorrência dessas alterações na superfície dentinária in vivo. Após a mensuração e registro do grau de sensibilidade inicial, a superfície foi moldada seguindo os mesmos procedimentos realizados com o Grupo 1. Uma reavaliação do grau de sensibilidade e novas moldagens para obtenção das réplicas positivas e negativas foram feitas após um intervalo de quatro semanas. 


\section{Obtenção das Réplicas}

Com o propósito de obter-se as réplicas de resina epóxica, foi confeccionada uma muralha de silicona de adição (Aquasil LV, Dentsply) com $5 \mathrm{~mm}$ de altura ao redor do molde a fim de acondicionar a resina epóxica ${ }^{106}$. Após um período de 24 horas, cada molde foi levemente secado com jato de ar e cuidadosamente vazado com resina epóxica de baixa viscosidade (Araldite Ciba), proporcionada e manipulada conforme os procedimentos descritos no estudo in vitro.

Após o endurecimento da resina, o que ocorreu em aproximadamente 24 horas, esta foi removida do molde, identificada e armazenada. Os espécimes (réplicas negativas e positivas) foram colados em stubs metálicos e metalizados com ouro no metalizador HUMMER VII (Alexandria, USA), com 30nm, para observação no Microscópio Eletrônico de Varredura (JSM - T220A; JEOL Ltd., Tokyo, Japão), com aumento de 1000X e voltagem de 15kV.

Com o intuito de padronizar a visualização das mesmas áreas e permitir a comparação das imagens, durante a observação da superfície dentinária no baseline, a área onde os túbulos dentinários estavam presentes foi anotada. Após quatro semanas, em ambos os grupos, procurou-se observar essa mesma área.

\section{ANÁLISE DOS DADOS}

Os resultados obtidos no presente trabalho foram baseados em observações qualitativas, sendo a análise dos dados de natureza puramente descritiva. 


\subsection{ESTUDO IN VITRO}

As Figuras 1 a 3 (págs. 98 a 101) mostram as imagens de microscopia eletrônica de varredura distribuídas de acordo com a seqüência de tratamento do espécime.

A Figura 1A, correspondente ao quadrante 1do disco de dentina, mostra a smear layer obstruindo a maioria dos túbulos dentinários, deixando alguns deles parcialmente abertos. O molde dessa região (Figura 2A) proporciona uma imagem invertida (réplica negativa) das estruturas apresentadas na figura anterior, com as irregularidades próprias da smear layer e projeções curtas do material de moldagem, correspondendo à reprodução das embocaduras semiexpostas dos túbulos dentinários. A imagem da réplica positiva (Figura 3A), obtida a partir desse molde, mostra uma superfície bastante semelhante à do espécime original (disco de dentina), com excelente reprodução da smear layer.

Depois do condicionamento com ácido cítrico a 6\% (Figura 1B), observase a completa remoção da smear layer, evidenciando a exposição da dentina e da embocadura dos túbulos dentinários. Essa imagem é típica da dentina desmineralizada superficialmente. O molde dessa região (Figura 2B) mostra que, devido à limpeza da superfície, o material de moldagem pode penetrar profundamente em alguns túbulos dentinários abertos, e formou longos tags retorcidos de silicona (setas), diferindo da imagem observada na Figura $2 \mathrm{~A}$. Em outros túbulos, o material de moldagem penetrou apenas parcialmente, formando tags mais curtos. A tensão induzida no material de moldagem no momento da remoção do molde, especificamente onde o material penetrou de maneira mais profunda nos túbulos abertos, resultou no rompimento de alguns tags. 
Remanescentes do material de moldagem podem ser vistos na imagem do disco de dentina (setas - Figura 1B ).

A Figura 3B é a imagem da réplica positiva do disco de dentina condicionado, e mostra os mesmos elementos presentes nos discos originais de dentina (Figura 1B), isto é, superfície dentinária limpa e as embocaduras dos túbulos abertas. Entretanto, são também vistas áreas de artefatos de técnica correspondentes aos prolongamentos retorcidos de silicona, que aparecem como baixos relevos unindo entre si dois ou mais túbulos dentinários (Figura 3B setas).

As Figuras 1C, 2C e 3C são fotomicrografias de microscopia eletrônica de varredura do disco de dentina após o tratamento com Oxa-Gel ${ }^{\circledR}$, do molde desse mesmo disco e de sua réplica em resina epóxica, respectivamente. As setas brancas na Figura 1C indicam que alguns túbulos permanecem obstruídos por remanescentes do material de moldagem que se rompeu durante a remoção do molde. Na mesma figura, as setas pretas indicam que a embocadura dos túbulos dentinários se encontra parcialmente obstruída pela deposição de cristais. Devido à obstrução parcial da embocadura dos túbulos, o molde dessa superfície (Figura 2C) mostra prolongamentos de silicona curtos e retos em sua grande maioria, resultando na produção de menor quantidade de artefatos na réplica de resina subsequente (Figura $3 \mathrm{C}$ ), quando comparada à réplica do disco de dentina condicionado com ácido cítrico (Figura 3B). Pode-se notar que as características da dentina tratada com Oxa-Gel ${ }^{\circledR}$ foram, em grande extensão, copiadas pela réplica, incluindo a presença de cristais na embocadura dos túbulos dentinários, indicados por setas pretas, e ainda remanescentes de tags de silicona (setas brancas). Após o desafio ácido, parte dos depósitos de cristais na embocadura dos túbulos foi dissolvida (Figura 1D), dando a essa superfície as mesmas 
características da superfície não tratada com Oxa-Gel ${ }^{\circledR}$. Muitos túbulos permanecem obstruídos com remanescentes do material de moldagem (setas). A fotomicrografia do molde (Figura 2D) mostra longos tags retorcidos de silicona, bem como tags curtos e rompidos, assim como no espécime não tratado. Entretanto, a réplica de resina epóxica (Figura 3D) revela a presença de pequenas embocaduras de túbulos, algumas delas com remanescentes da precipitação de cristais (setas pretas), enquanto outras permanecem obstruídas com fragmentos de material de moldagem (setas brancas). A ausência de defeitos superficiais indica que a área mostrada nesta figura não é semelhante à imagem da fotomicrografia do molde (Figura 2D). 


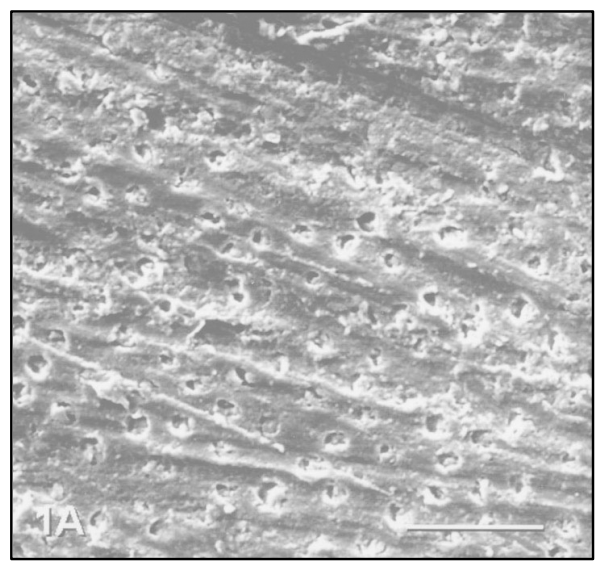

Figura 1A: Fotomicrografia eletrônica de varredura do disco de dentina. Os túbulos dentinários estão completamente cobertos por smear layer. (Barra = $10 \mu \mathrm{m}, \mathrm{X} 1000)$.

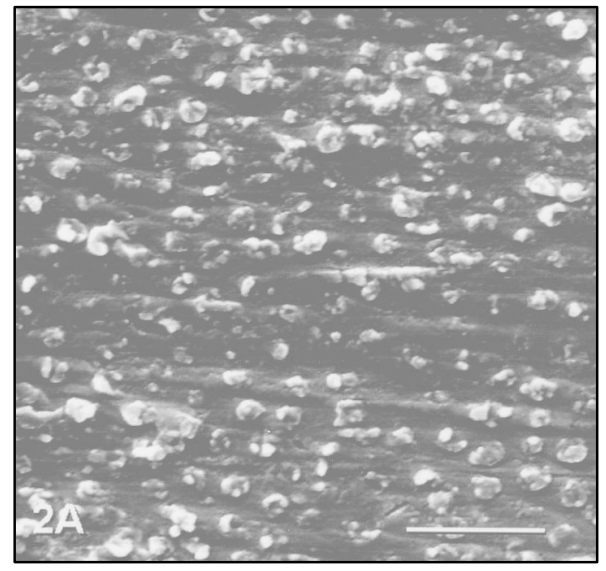

Figura 2A: Fotomicrografia eletrônica de varredura do molde (réplica negativa) do disco de dentina. Podem ser observadas algumas curtas projeções do material de moldagem. (Barra $=10 \mu \mathrm{m}, \mathrm{X1000})$.

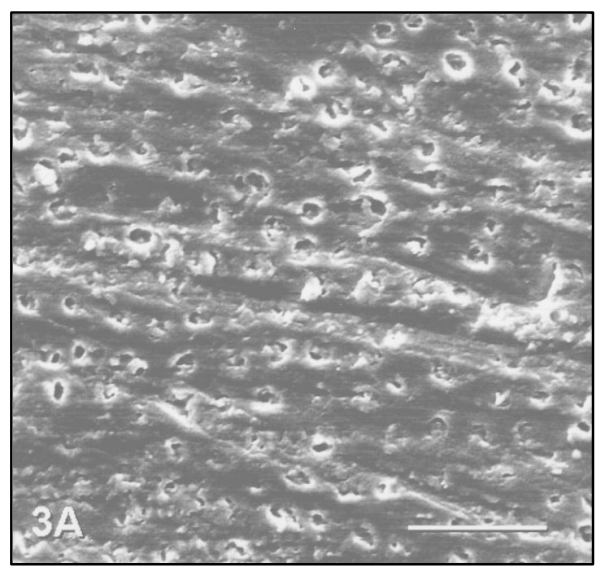

Figura 3A: Fotomicrografia eletrônica de varredura da réplica positiva do disco de dentina. As mesmas características da smear layer do espécime original podem ser observadas. (Barra $=10 \mu \mathrm{m}, \mathrm{X} 1000)$. 


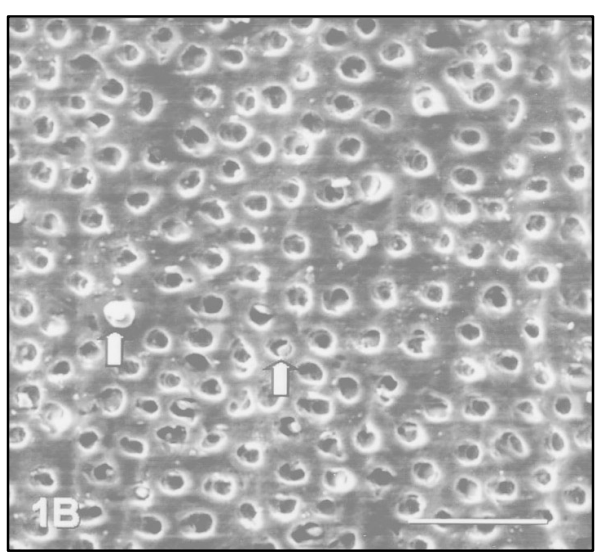

Figura 1B: Fotomicrografia eletrônica de varredura do disco de dentina após o condicionamento ácido. A smear layer foi completamente removida, revelando túbulos dentinários abertos. Podem ser vistos remanescentes de material de moldagem (setas). (Barra $=10 \mu \mathrm{m}, \mathrm{X} 1000)$.

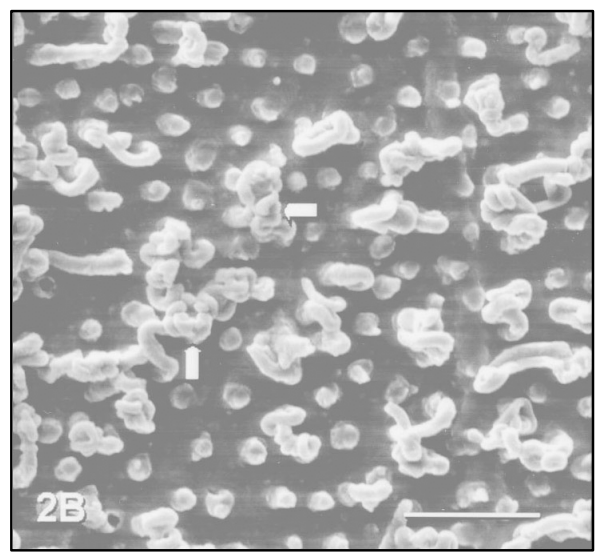

Figura 2B: Fotomicrografia eletrônica de varredura do molde (réplica negativa) do disco de dentina condicionado com ácido. Observam-se longas projeções de silicona formadas pela penetração profunda do material de moldagem nos túbulos dentinários. (Barra $=10 \mu \mathrm{m}, \mathrm{X1000})$.

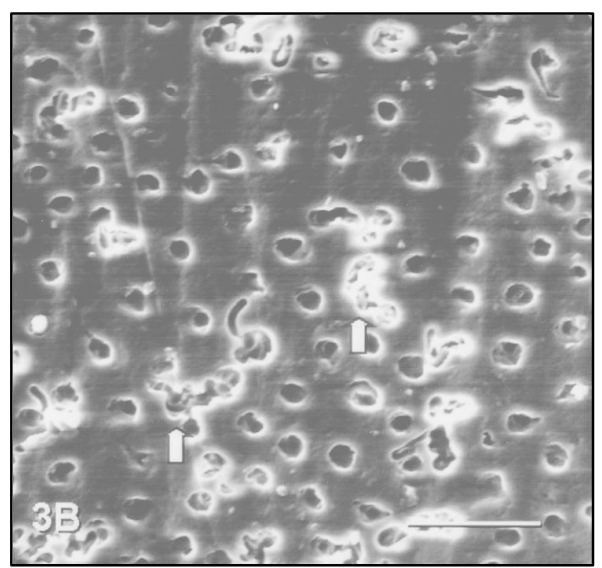

Figura 3B: Fotomicrografia eletrônica de varredura da réplica positiva do disco de dentina condicionado com ácido. Uma superfície limpa, túbulos dentinários abertos e alguns artefatos podem ser observados. (Barra $=10 \mu \mathrm{m}, \mathrm{X1000}$ ). 


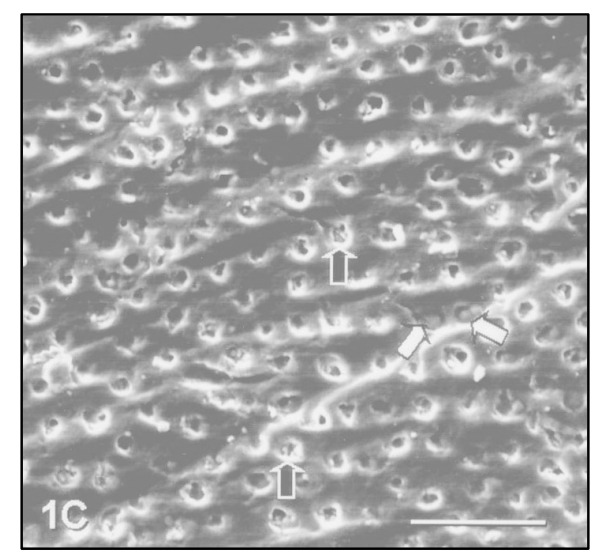

Figura 1C: Fotomicrografia eletrônica de varredura do disco de dentina após o tratamento com Oxa-Gel ${ }^{\circledR}$. As aberturas dos túbulos dentinários encontram-se parcialmente ocluídas por precipitação de cristais (setas pretas), e outros túbulos estão obstruídos por tags de silicona (setas brancas) (Barra =10 $\mu \mathrm{m}, \mathrm{X1000}$ ).

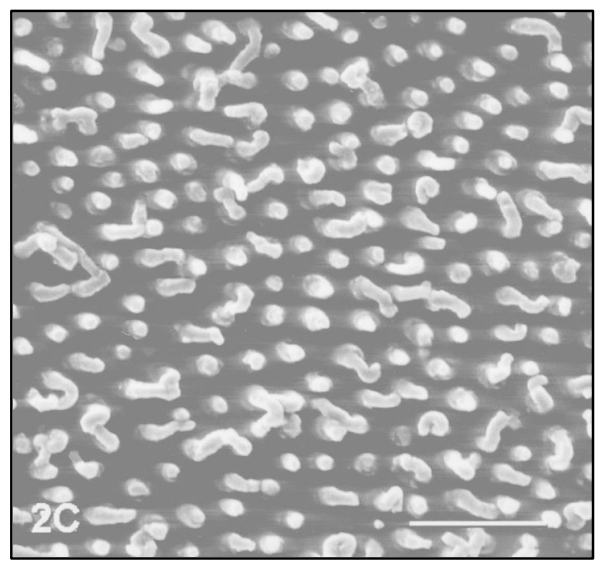

Figura 2C: Fotomicrografia eletrônica de varredura do molde (réplica negativa) do disco de dentina. Podem ser observados tags de silicona curtos e eretos devido à obliteração dos túbulos dentinários. (Barra $=10 \mu \mathrm{m}, \mathrm{X} 1000$ ).

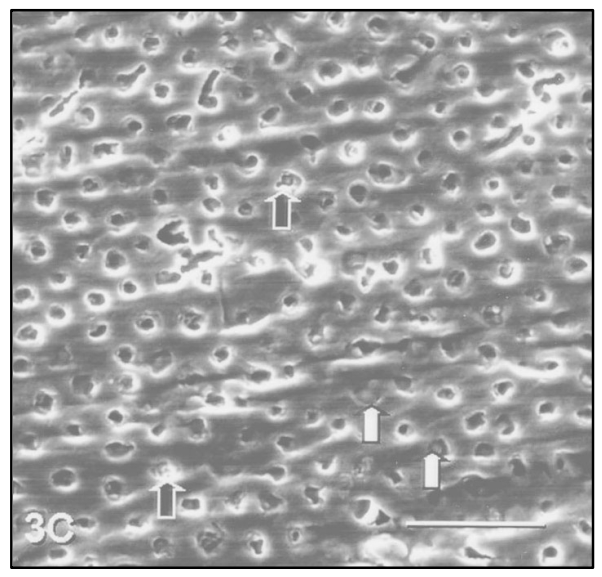

Figura 3C: : Fotomicrografia eletrônica de varredura da réplica positiva do disco de dentina após o tratamento com Oxa-Gel ${ }^{\circledR}$. A réplica foi capaz de copiar os cristais precipitados (setas pretas) e, ainda, outros túbulos obliterados por fragmentos de silicona (setas brancas) (Barra $=10 \mu \mathrm{m}, \mathrm{X} 1000)$. 


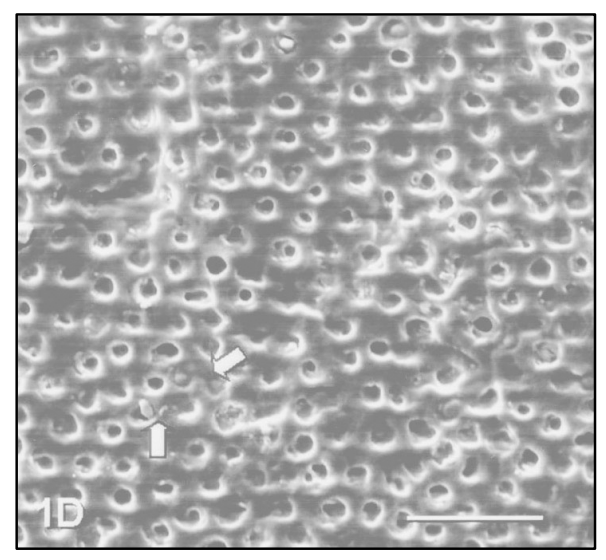

Figura 1D: Fotomicrografia eletrônica de varredura do disco de dentina após o tratamento com Oxa-Gel ${ }^{\circledR}$ e condicionado com ácido novamente. Alguns dos depósitos na abertura dos túbulos foram removidos, e o material de moldagem remanescente ainda mantém alguns túbulos fechados (setas). (Barra $=10 \mu \mathrm{m}$, X1000).

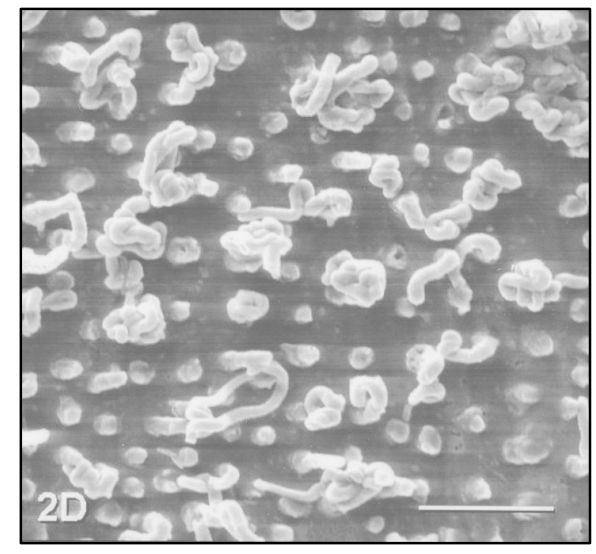

Figura 2D: Fotomicrografia eletrônica de varredura do molde (réplica negativa) do disco de dentina após o tratamento com Oxa-Gel ${ }^{\circledR}$ e condicionado com ácido novamente. Podem ser observados tags retorcidos de silicona e alguns curtos e rompidos. (Barra $=10 \mu \mathrm{m}, \mathrm{X} 1000)$.

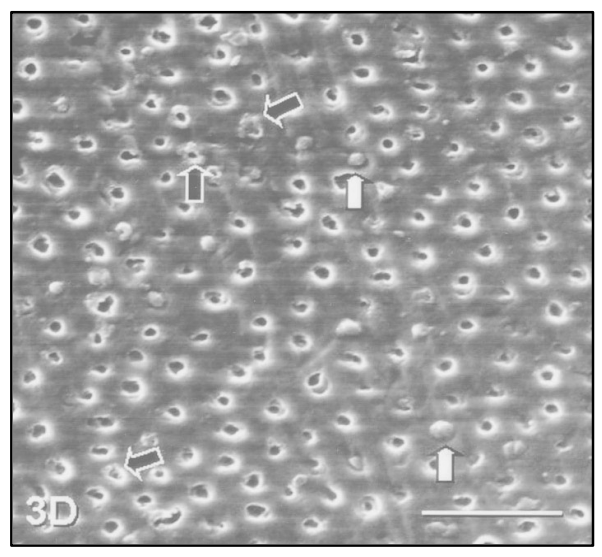

Figura 3D: Fotomicrografia eletrônica de varredura da réplica positiva do disco de dentina após o tratamento com Oxa-Gel ${ }^{\circledR}$ e recondicionamento com ácido. Pequenas aberturas de túbulos dentinários e sinais da precipitação de cristais podem ser vistos (setas pretas). Outros túbulos permanecem obstruídos por silicona remanescente (setas brancas) (Barra $=10 \mu \mathrm{m}, \mathrm{X} 1000)$. 


\subsection{ESTUDO IN VIVO}

Interpretação das Imagens

As Figuras 4 a 9 (págs. 104 a 106) mostram detalhes das imagens obtidas nos Grupos 1 e 2. Realizaram-se fotomicrografias de microscopia eletrônica de varredura com aumentos de 1000X, 3500X e 5000X, as quais foram observadas de topo e com inclinação de $50^{\circ}$ com o objetivo de favorecer uma correta interpretação das imagens e, consequentemente, do relato dos resultados obtidos para ambos os grupos estudados.

A Figura 4 corresponde à fotomicrografia eletrônica de varredura obtida a partir da moldagem de uma superfície de dentina diagnosticada como hiperestésica. Vista de topo e com aumento de 1000X, pode-se notar uma grande quantidade de túbulos dentinários com diâmetros diferentes, e que poderiam ser interpretados como túbulos dentinários abertos (setas brancas) ou fechados (setas pretas).

A mesma superfície foi observada com aumentos de 3500X (Figura 5) e 5000X (Figura 6). Em ambas as figuras, a imagem obtida parece ser a cópia negativa de uma superfície em relevo (setas brancas). Os detalhes apontados pelas setas pretas oferecem a mesma idéia, embora possam ser interpretados como a imagem de túbulos dentinários fechados, também com diâmetros diferentes.

Quando a mesma superfície foi observada com inclinação de $50^{\circ}$, com aumento de 1000X (Figura 7), pode-se observar grande quantidade de túbulos dentinários com características e diâmetros diferentes.

$\mathrm{Na}$ mesma imagem com aumento de 3500X (Figura 8), observam-se diferentes padrões das projeções do material de moldagem, as quais podem ocorrer em função da maior (setas brancas) ou menor (setas pretas) penetração 
do material de moldagem nos túbulos dentinários. Provavelmente, quando esse material entrou em contato com o fluido dentinário, formaram-se bolhas que impediram a formação de tags de silicona, como aqueles observados no estudo in vitro.

A imagem obtida com aumento de 5000X (Figura 9) deixa claro que, o que parecia ser uma concavidade, era, na verdade, a projeção do material de moldagem no interior de túbulos dentinários abertos ou parcialmente abertos (setas brancas). As setas pretas indicam que, em alguns pontos, a imagem continua sendo a de uma superfície côncava. Alguns autores (BEVENIUS; LINDSKOG;HULTENBY, 1994) sugerem que essa seria a imagem negativa de gotas de fluido dentinário aflorando à superfície dos túbulos. A Figura 10 (pág. 107) é um desenho representativo da interpretação dos diferentes padrões de imagem obtidos.

$\mathrm{Na}$ interpretação dessas imagens, pode-se observar com clareza os túbulos dentinários total ou parcialmente abertos, sendo praticamente impossível diferenciar túbulos fechados. 


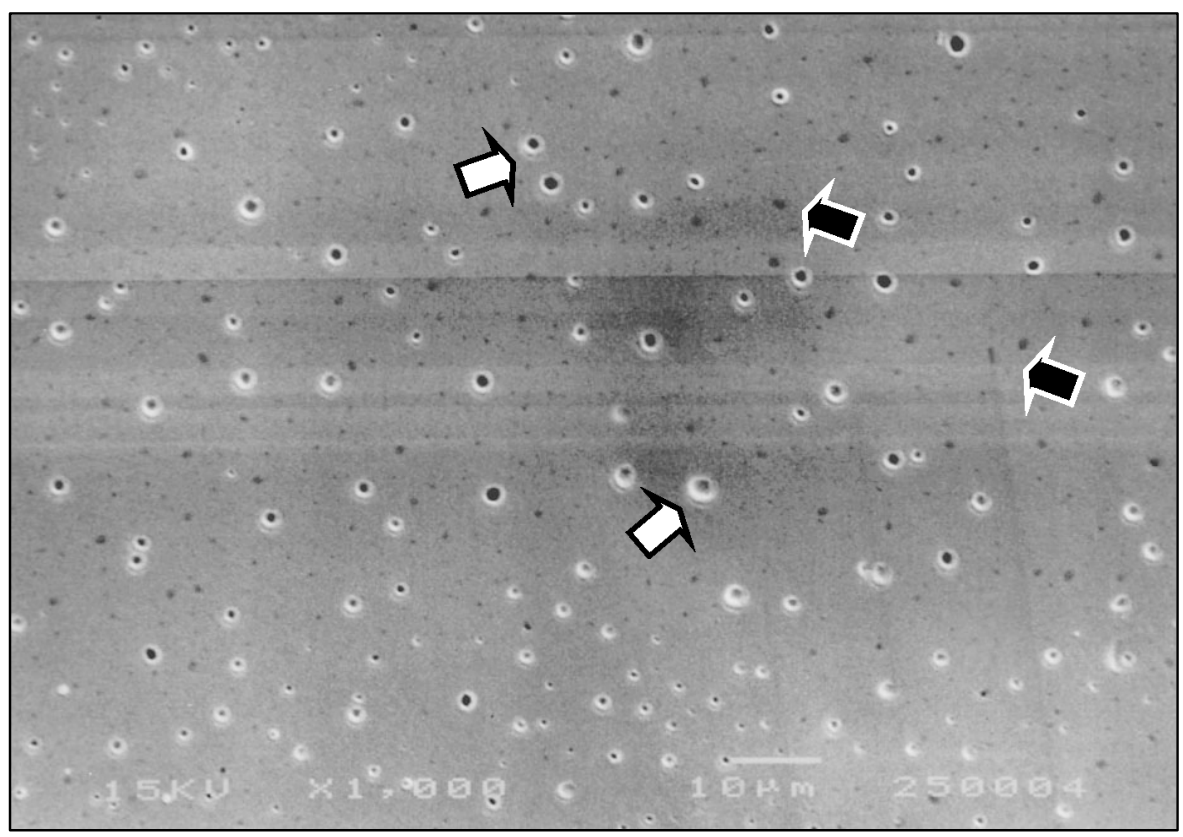

Figura 4: Fotomicrografia eletrônica de varredura da réplica negativa (molde) da superfície de dentina hiperestésica com aumento de 1000X, vista de topo. Notese a presença de inúmeros túbulos dentinários com diferentes diâmetros, os quais poderiam ser classificados, num primeiro momento, como túbulos abertos (setas brancas) ou fechados (setas pretas).

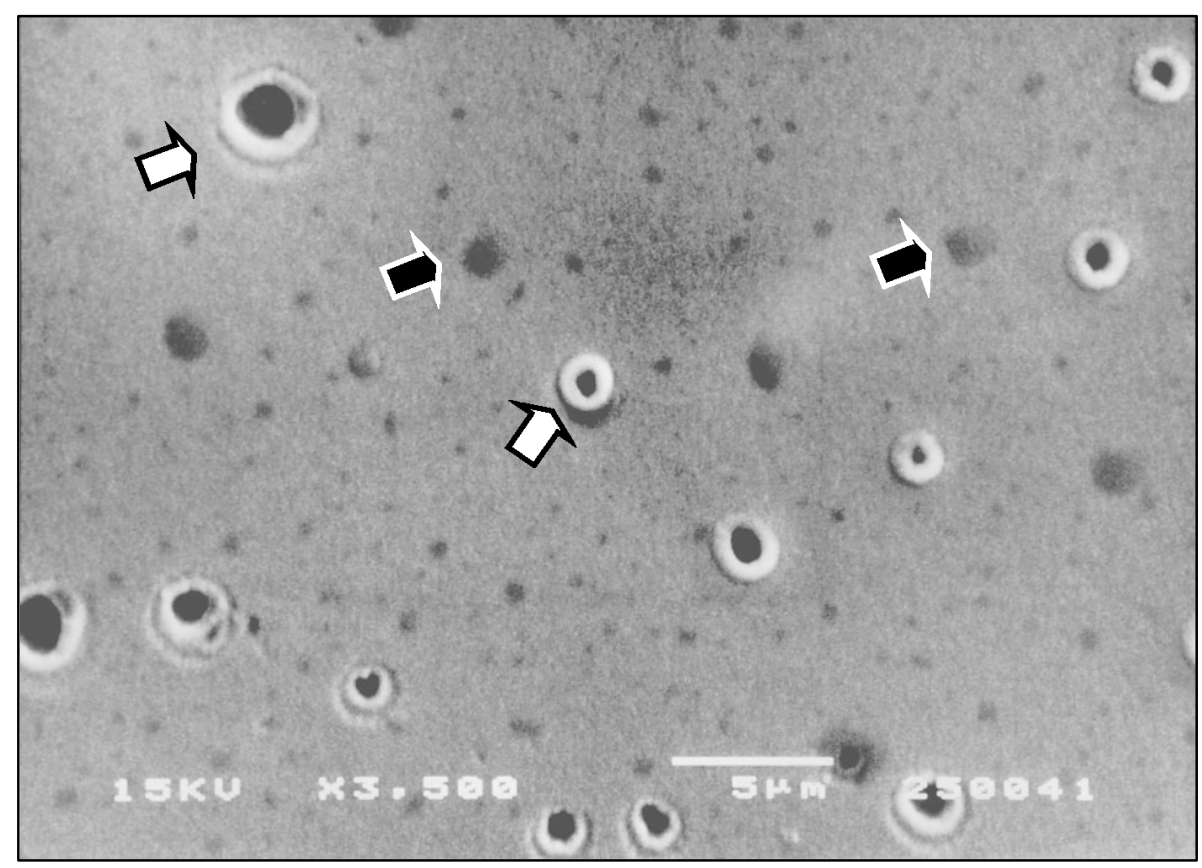

Figura 5: Fotomicrografia eletrônica de varredura da réplica negativa (molde) da mesma superfície de dentina hiperestésica. Em maior aumento (X3500), as imagens apontadas pelas setas brancas parecem ser o negativo de uma superfície em relevo. As estruturas apontadas por setas pretas podem ser interpretadas como sendo a imagem de túbulos dentinários fechados. 


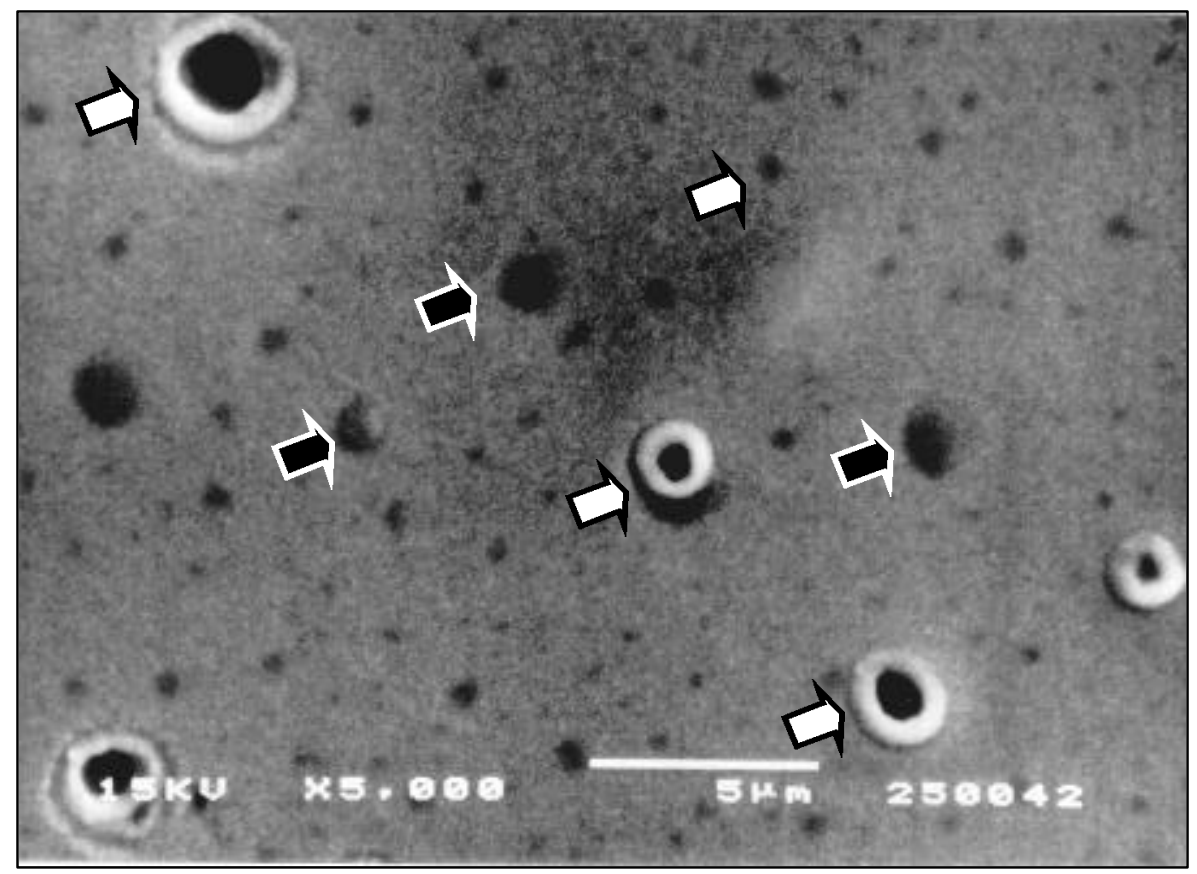

Figura 6: Fotomicrografia eletrônica de varredura da réplica negativa (molde) da mesma superfície de dentina hiperestésica, com aumento de 5000X. As imagens apontadas pelas setas brancas parecem ser o negativo de uma superfície em relevo, e as estruturas apontadas por setas pretas podem ser interpretadas como sendo a imagem de túbulos dentinários fechados.

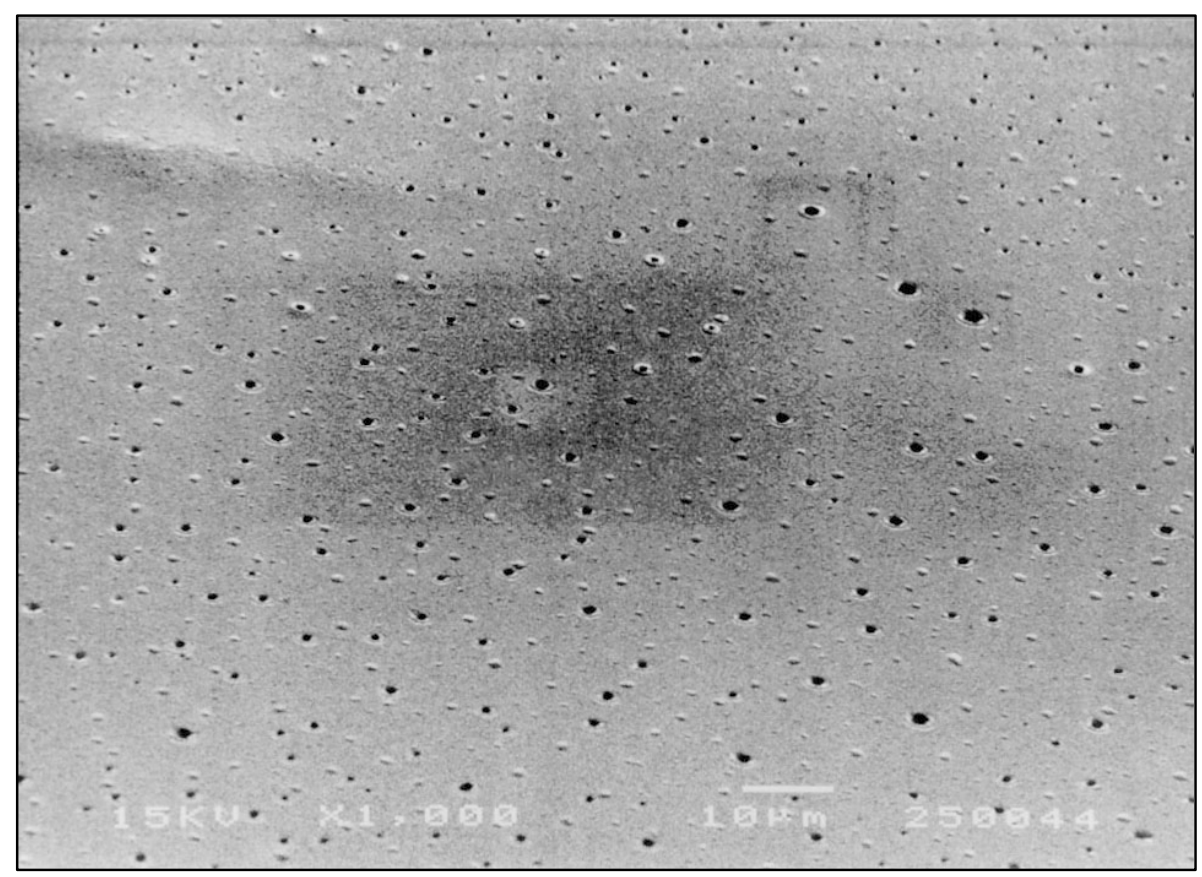

Figura 7: Microscopia eletrônica de varredura da réplica negativa (molde) da superfície de dentina hiperestésica, com aumento de $1000 \mathrm{X}$ e inclinação de $50^{\circ}$. Nessa angulação, pode-se observar a imagem de túbulos dentinários, mas com características e diâmetros diferentes. 


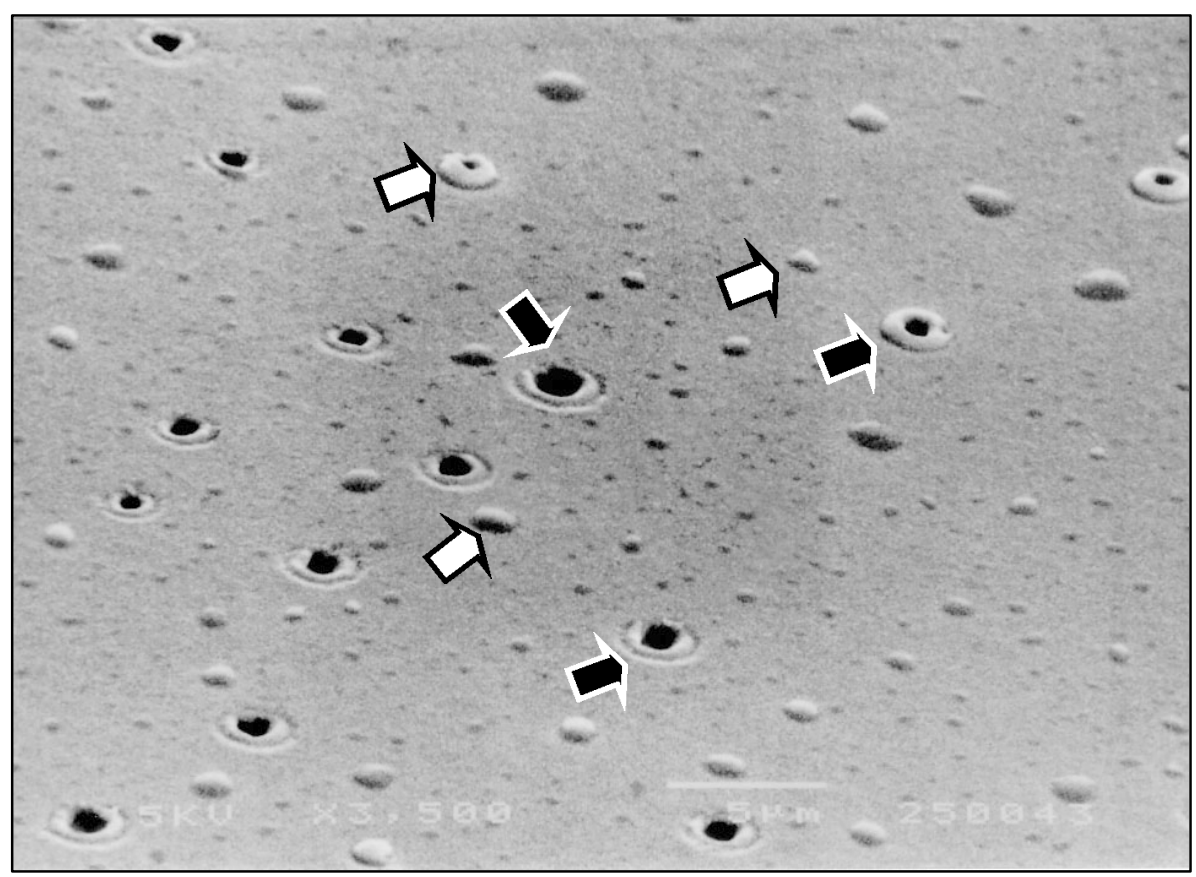

Figura 8: Fotomicrografia eletrônica de varredura da réplica negativa (molde) da superfície de dentina hiperestésica, em aumento de $3500 \mathrm{X}$ e inclinação de $50^{\circ}$. Pode-se observar que o material de moldagem penetrou mais em alguns túbulos (setas brancas) e menos em outros túbulos (setas pretas).

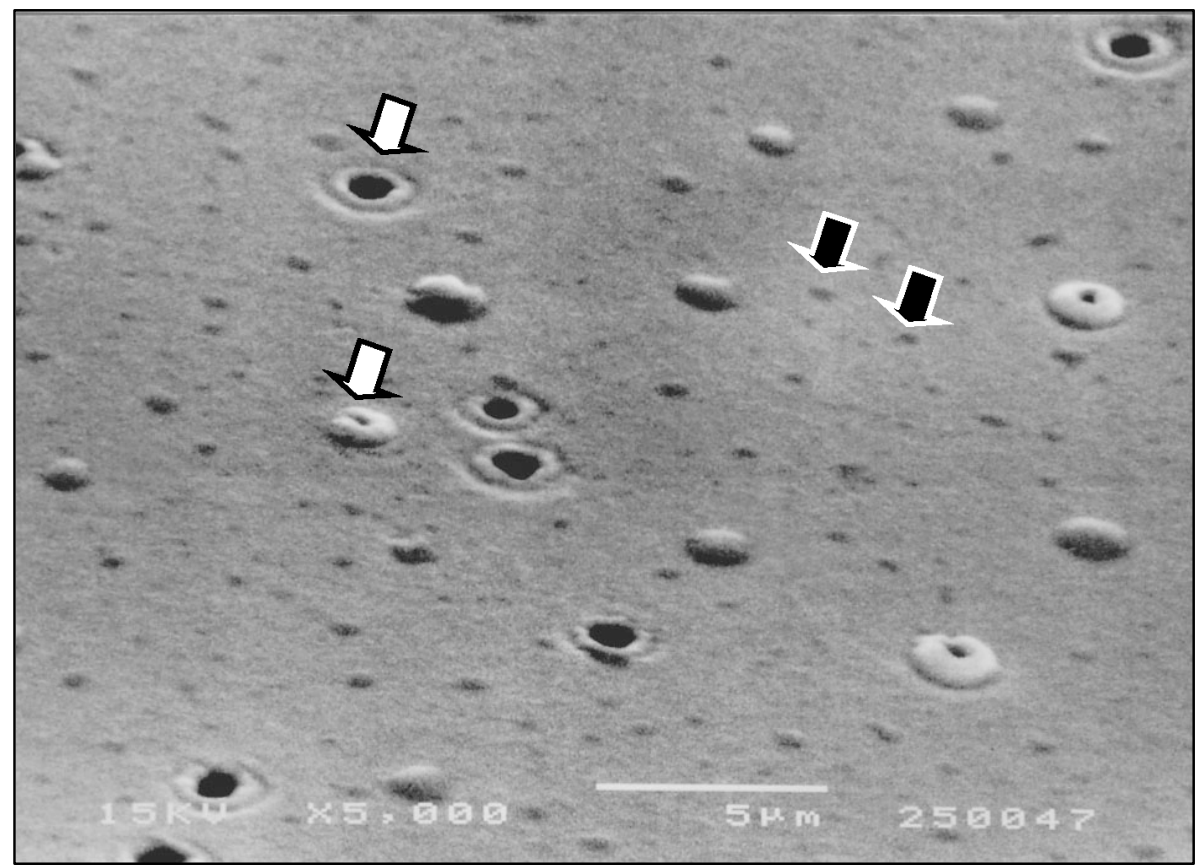

Figura 9: Microscopia eletrônica de varredura da réplica negativa (molde) da superfície de dentina hiperestésica, em aumento de 5000X e inclinação de $50^{\circ}$. Os mesmos padrões de projeção do material de moldagem podem ser observados (setas brancas). As setas pretas indicam a imagem de uma superfície côncava, podendo ser interpretada como a réplica negativa de gotículas de fluido dentinário. 


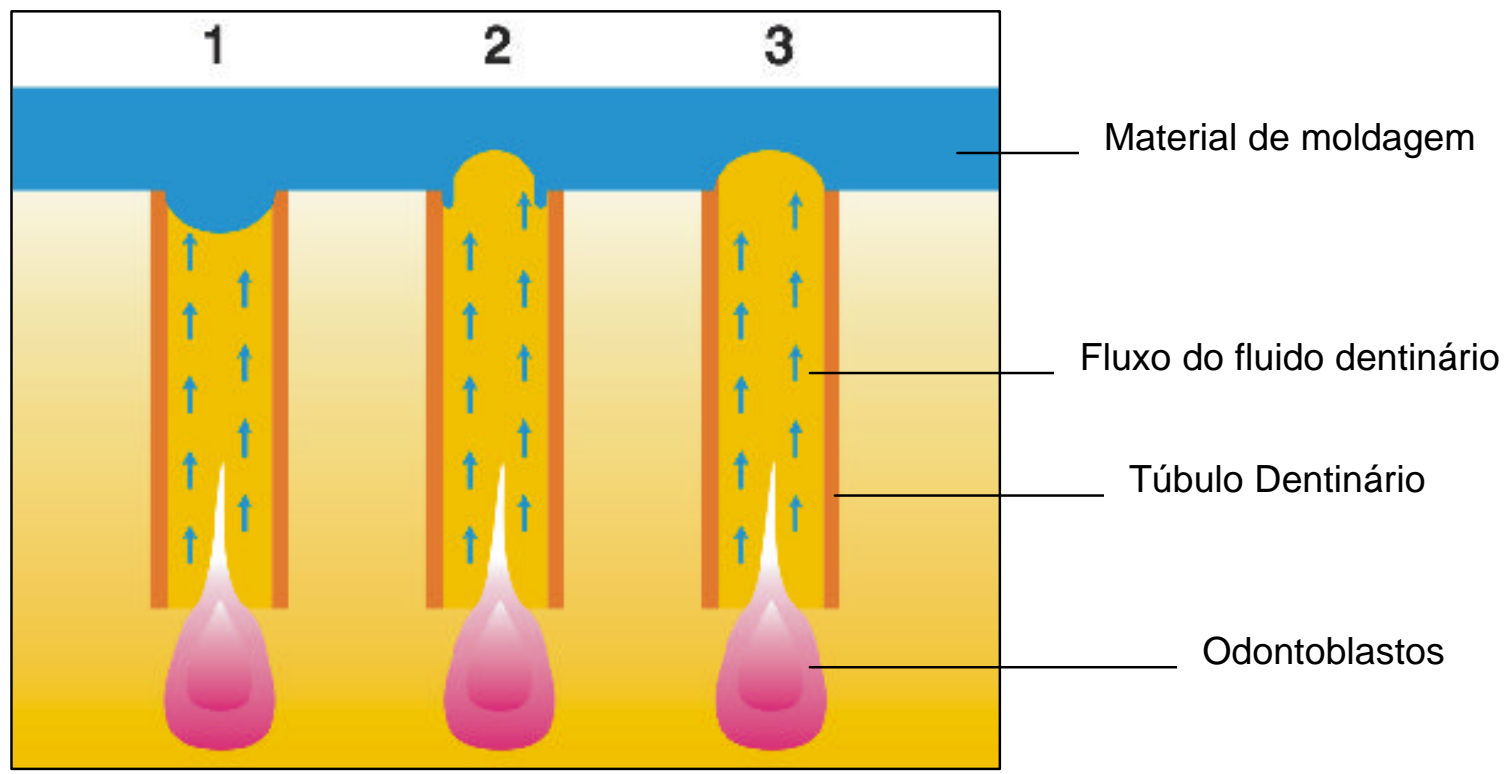

A)

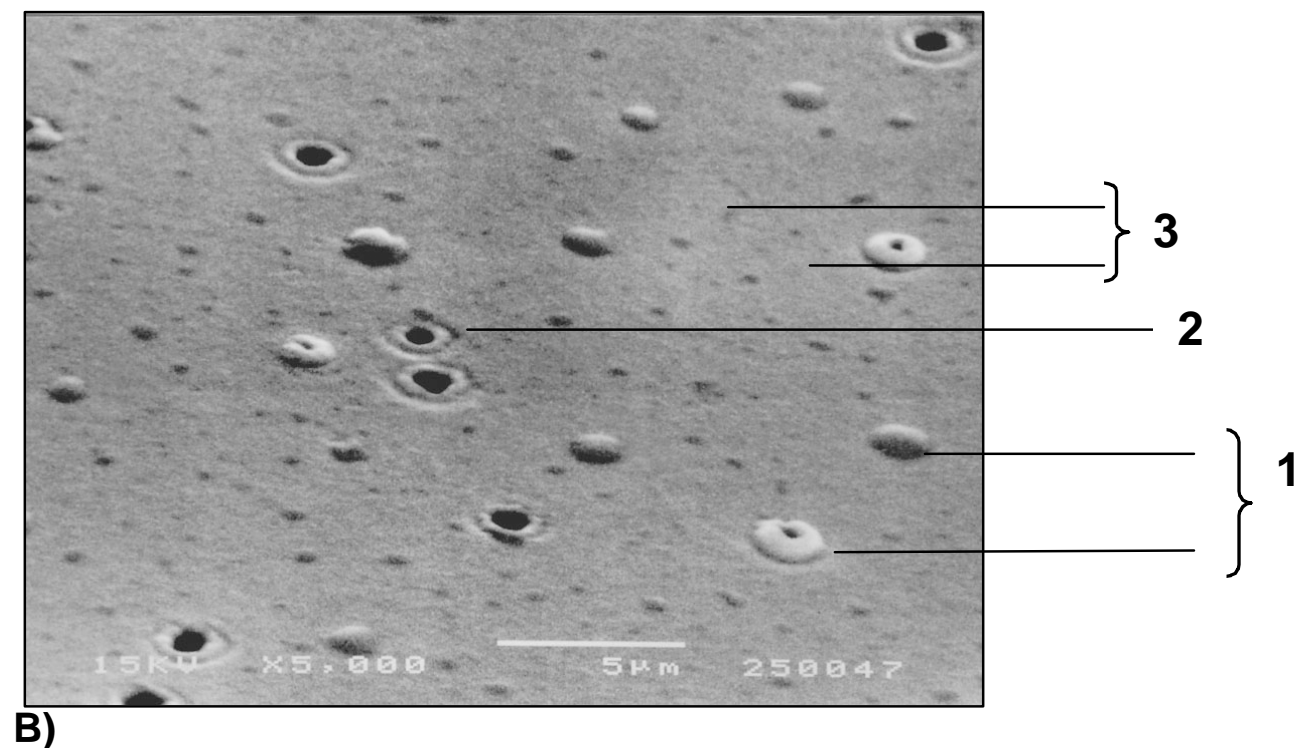

Figura 10: Desenho representativo (A) dos diferentes padrões de projeção do material de moldagem no interior dos túbulos dentinários, que podem ser observados na fotomicrografia (B). O padrão 1 representa a situação em que o material de moldagem penetrou mais profundamente na embocadura do túbulo dentinário, podendo ou não apresentar pequenas bolhas. No padrão 2, o material de moldagem penetrou no túbulo dentinário, justapondo-se às suas paredes. A pressão hidráulica no interior dos túbulos deslocou o material de volta, exceto na área periférica, onde o material permaneceu aderido às paredes da dentina, dando a essa imagem a aparência de anel. O padrão 3 representa a situação em que a pressão do fluido dentinário não permitiu a penetração do material de moldagem no túbulo, resultando em uma imagem sugestiva do molde das gotículas do próprio fluido dentinário. 


\section{GRUPO 1}

Participaram desse grupo 8 pacientes, sendo 4 do gênero feminino e 4 do gênero masculino, com idades entre 32 e 45 anos. Foram selecionados 16 dentes caninos e pré-molares com dentina cervical exposta, diagnosticada como hiperestésica, pois apresentavam grau de sensibilidade mínimo aos estímulos sonda ou ar correspondente a 3cm de acordo com a Escala Analógica Visual (EVA).

A Figura 5.1, a seguir, mostra a relação de pacientes, dentes, grau de sensibilidade aos estímulos sonda e ar antes e depois do tratamento com Oxa$\mathrm{Gel}^{\circledR}$, bem como a relação dos espécimes (réplicas negativas).

\begin{tabular}{|l|l|l|l|l|l|l|l|}
\hline \multirow{2}{*}{$\begin{array}{l}\text { PAC. } \\
\text { Ficha n }\end{array}$} & \multirow{2}{*}{ DENTE } & \multirow{2}{*}{ AMOSTR } & \multicolumn{2}{|c|}{ GS INICIAL } & AMOSTRA & \multicolumn{2}{c|}{ GS FINAL } \\
& & & SONDA & AR & & SONDA & AR \\
\hline 01 & 14 & 01 & 10,0 & 10,0 & 25 & 0,5 & 7,5 \\
\hline 01 & 35 & 02 & 10,0 & 10,0 & 26 & 0,0 & 0,0 \\
\hline 02 & 44 & 03 & 7,5 & 8,5 & 27 & 1,5 & 2,0 \\
\hline 02 & 45 & 04 & 5,5 & 7,5 & 28 & 0,8 & 1,0 \\
\hline 04 & 13 & 06 & 6,5 & 7,5 & 30 & 1,5 & 0,8 \\
\hline 04 & 14 & 07 & 1,9 & 4,8 & 31 & 0,0 & 0,0 \\
\hline 05 & 13 & 08 & 7,6 & 3,2 & 32 & 0,0 & 0,9 \\
\hline 05 & 14 & 09 & 8,6 & 4,2 & 33 & 0,0 & 1,2 \\
\hline 05 & 15 & 10 & 9,3 & 4,0 & 34 & 0,8 & 1,7 \\
\hline 05 & 23 & 11 & 6,0 & 5,8 & 35 & 0,0 & 1,8 \\
\hline 07 & 33 & 12 & 4,9 & 3,9 & 36 & 0,0 & 1,8 \\
\hline 07 & 34 & 13 & 7,2 & 9,0 & 37 & 0,6 & 1,5 \\
\hline 08 & 13 & 14 & 6,0 & 7,8 & 38 & 0,8 & 0,5 \\
\hline 08 & 14 & 15 & 7,4 & 9,0 & 39 & 0,8 & 1,5 \\
\hline 09 & 45 & 16 & 10,0 & 10,0 & 40 & 2,5 & 1,3 \\
\hline 11 & 45 & 17 & 10,0 & 9,0 & 41 & 5,2 & 0,0 \\
\hline
\end{tabular}

Figura 5.1: Relação de Pacientes, Dentes, Grau de Sensibilidade Inicial e Final e Espécimes do Grupo 1 
Conforme se ressaltou no capítulo Material e Método, foram selecionados pacientes com diferentes graus de sensibilidade aos estímulos sonda e jato de ar, pois o objetivo do presente trabalho não foi avaliar a eficácia do agente dessensibilizante utilizado, e sim avaliar se a técnica de réplica pode ser utilizada para monitorar clinicamente o efeito de agentes anti-hiperestésicos. Observou-se, ainda, a possibilidade de correlacionar as características superficiais da dentina com o grau de sensibilidade relatado pelo paciente antes e depois do tratamento.

Desse modo, algumas fotomicrografias representativas do Grupo 1 foram selecionadas. As Figuras 11 a 18 (págs. 113 a 121) correspondem às fotomicrografias eletrônicas de varredura das réplicas negativas obtidas a partir da moldagem das superfícies dentinárias hiperestésicas do Grupo 1 no baseline (A) e imediatamente após a quarta aplicação do Oxa-Gel ${ }^{\circledR}(B)$.

A Figura 11A corresponde ao molde, ou réplica negativa, de uma superfície dentinária de um paciente com grau de sensibilidade inicial, ou seja, no baseline, descrito como desconforto severo (grau 10) tanto ao estímulo táctil (sonda exploradora) quanto ao estímulo térmico-evaporativo (jato de ar). Pode-se notar que existe uma grande quantidade de túbulos dentinários total ou parcialmente abertos, o que caracteriza a dentina hiperestésica. Na réplica negativa (Figura 11B) da mesma superfície após 4 aplicações de Oxa-Gel ${ }^{\circledR}$, pode-se notar que, aparentemente, os túbulos dentinários estão em menor número. Apesar de não haver vestígios do agente dessensibilizante, o paciente relatou uma diminuição significativa no grau de sensibilidade ao estímulo sonda $(0,5)$, embora a dor permanecesse ainda intensa ao estímulo ar $(7,5)$. Ainda nessa fotomicrografia, pode-se observar a presença de imagens sugestivas da réplica negativa de gotas de fluido dentinário (setas). 
As Figuras $11 \mathrm{C}$ e 11D correspondem às fotomicrografias da réplica positiva da superfície dentinária hiperestésica no baseline, vista de topo (X1000) e com inclinação de $50^{\circ}$ (X5000). Apesar de o molde apresentar riqueza de detalhes, a resina epóxica não foi capaz de reproduzi-los, podendo-se visualizar a presença de inúmeras bolhas (setas). Esse padrão de imagem repetiu-se em todas as réplicas positivas, ou seja, a resina epóxica não copiou os detalhes superficiais como ocorreu no estudo in vitro. A partir dessa constatação, optou-se por observar somente as réplicas negativas em ambos os grupos estudados.

A Figura $12 \mathrm{~A}$ é a fotomicrografia da réplica negativa da superfície dentinária de um paciente que relatou grau de sensibilidade inicial muito intenso $(8,6)$ ao estímulo sonda e moderado $(4,2)$ ao jato de ar. Podem ser observados túbulos dentinários de maior diâmetro e em grande quantidade. Interpretaram-se algumas imagens como sendo túbulos dentinários fechados (setas). A réplica negativa da mesma superfície, feita imediatamente após a quarta aplicação do Oxa-Gel ${ }^{\circledR}$ (Figura 12B), mostra uma superfície em que os túbulos dentinários não estão mais completamente visíveis, mas obliterados, provavelmente, pela ação do agente dessensibilizante (setas). Essas características são condizentes com a total remissão do grau de sensibilidade ao estímulo sonda e a considerável diminuição da sensibilidade ao estímulo ar $(1,2)$ relatados pelo paciente.

$\mathrm{Na}$ Figura 13A, observa-se, ainda, uma grande quantidade de túbulos dentinários, embora de diâmetros menores quando comparados à Figura 12A. Nesse caso, o paciente também relatou sensibilidade extremamente intensa à sonda $(9,3)$ e moderada $(4,0)$ ao jato de ar. Na fotomicrografia representativa do final do tratamento com o agente dessensibilizante (Figura 13B), observa-se o mesmo padrão de imagem da figura anterior, ou seja, grande quantidade de 
túbulos dentinários, embora o paciente tenha relatado ausência de desconforto $(0,8)$ ao estímulo sonda e quase imperceptível $(1,7)$ ao estímulo ar.

A Figura 14A mostra uma superfície dentinária com grande quantidade de túbulos dentinários de um paciente com desconforto forte $(6,0)$ ao estímulo sonda e levemente forte $(5,8)$ ao jato de ar. Após o tratamento com o agente dessensibilizante (Figura 14B), o paciente relatou remissão completa da dor ao estímulo sonda e desconforto quase imperceptível $(1,8)$ ao estímulo ar. Nesse momento, a superfície dentinária apresentou menor quantidade de túbulos, porém com maior diâmetro, quando comparados ao diâmetro dos túbulos no baseline.

Na Figura 15A, pode-se observar uma imagem diferente do padrão anterior. Nessa fotomicrografia, a superfície dentinária apresenta áreas em que os túbulos dentinários estão completamente ausentes (setas brancas) e em outras áreas estão expostos (setas pretas), apresentando diferentes diâmetros. Apesar dessas características, o paciente relatou sensibilidade intensa $(7,2)$ ao estímulo sonda e extremamente intensa $(9,0)$ ao estímulo jato de ar no baseline. Após o tratamento (Figura 15B), o paciente relatou remissão quase que total a ambos os estímulos (0,6 à sonda e 1,5 ao jato de ar), e quase nenhum túbulo dentinário pode ser observado na mesma superfície. Nas duas figuras, as setas vermelhas indicam a presença de trincas no espécime de silicona, provavelmente resultantes da manipulação do espécime durante a fixação nos stubs metálicos.

Na Figura 16A, a superfície revela características de dentina hiperestésica, ou seja, grande quantidade de túbulos dentinários. O paciente relatou forte desconforto $(6,0)$ ao estímulo sonda e intenso $(7,8)$ ao jato de ar. Após o tratamento com o agente dessensibilizante (Figura 16B), observou-se que a quantidade de túbulos se manteve, apesar de o paciente ter relatado grau de 
sensibilidade quase imperceptível aos estímulos aplicados $(0,8$ à sonda e 0,5 ao jato de ar).

A réplica negativa, mostrada na Figura 17A, também apresenta um grande número de túbulos dentinários, condizentes com o desconforto extremamente intenso ao estímulo sonda $(9,3)$ e moderado $(4,0)$ ao estímulo ar, relatados pelo paciente. Após o tratamento, os túbulos dentinários são bastante numerosos, como se pode observar na Figura 17B, ainda que o desconforto do paciente tenha diminuído para quase imperceptível $(0,8)$ e leve $(1,7)$ aos estímulos sonda e jato de ar, respectivamente.

$\mathrm{Na}$ Figura 18A, existe uma grande quantidade de túbulos dentinários, embora de diâmetros reduzidos, caracterizando a dentina hiperestésica (grau 10,0 ao estímulo sonda e 9,0 ao jato de ar). Após o tratamento (Figura 18B), o paciente não mais relatou sensibilidade como no baseline, e sim um desconforto levemente forte $(5,2)$ somente ao estímulo sonda. Pode-se observar uma diminuição considerável do número de túbulos dentinários, agora com diâmetros maiores do que aqueles vistos na situação anterior. Trincas estão, novamente, presentes (setas vermelhas). 


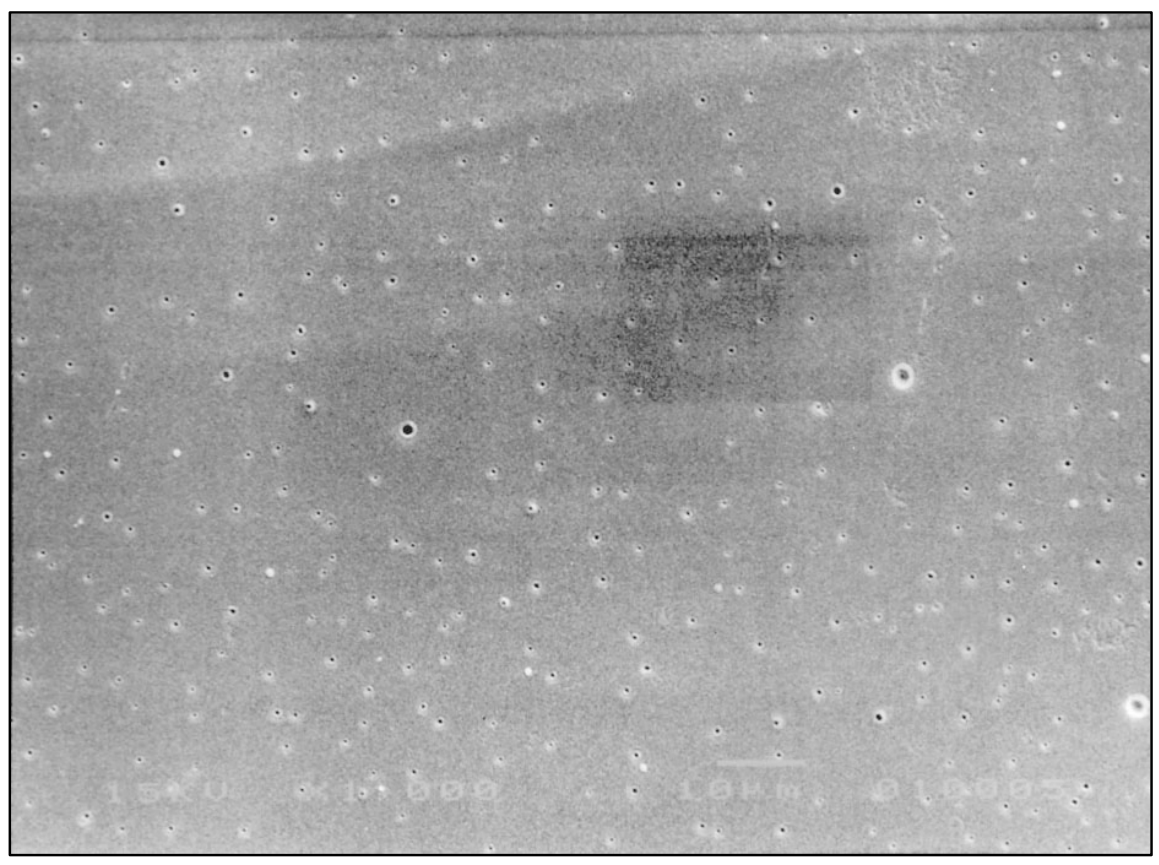

Figura 11A: Fotomicrografia eletrônica de varredura da réplica negativa da superfície dentinária de um paciente com desconforto extremo $(10,0)$ inicial para ambos os estímulos (sonda exploradora e jato de ar). Observe-se a grande quantidade de túbulos dentinários total ou parcialmente abertos, característicos de dentina hiperestésica.

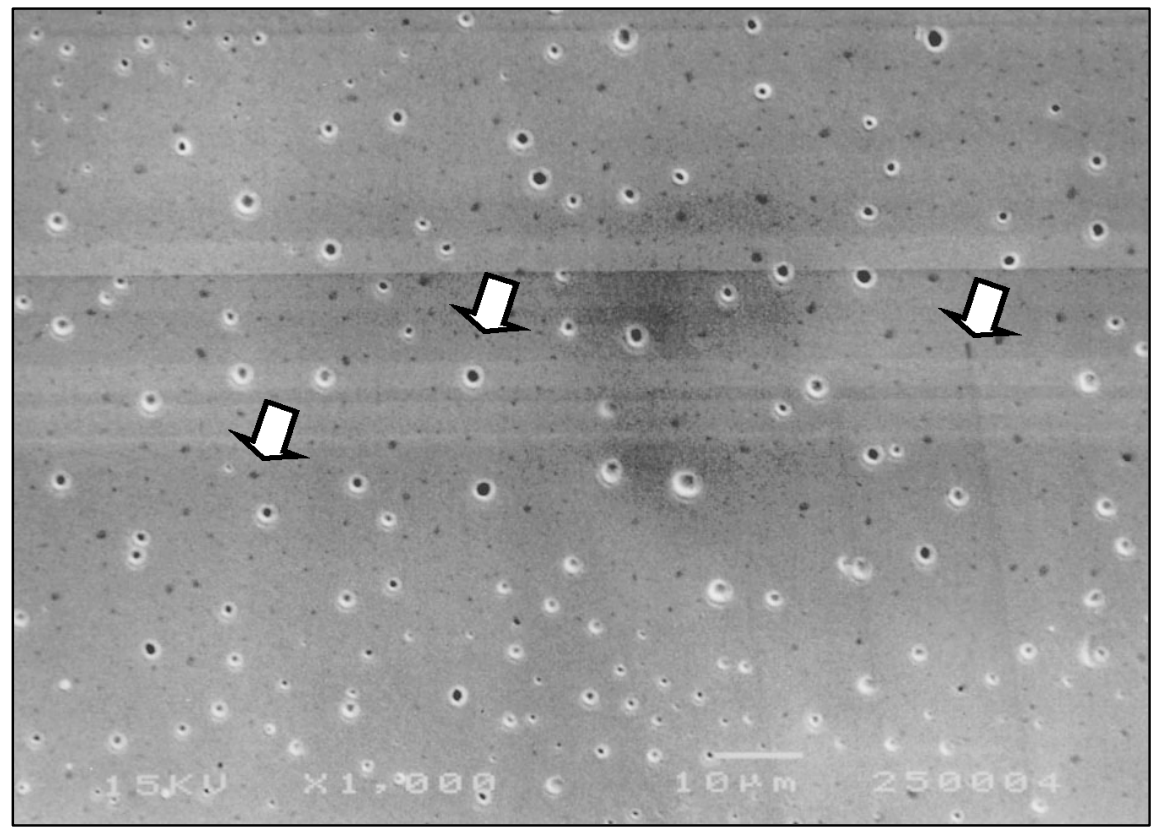

Figura 11B: Fotomicrografia eletrônica de varredura da réplica negativa da mesma superfície após 4 aplicações de Oxa-Gel ${ }^{\circledR}$. Nota-se que os túbulos dentinários estão em menor número. Apesar da melhora relatada pelo paciente (0,5 ao estímulo sonda e 7,5 ao estímulo ar), não há vestígios do agente dessensibilizante. As setas indicam imagens sugestivas de réplica das gotas de fluido dentinário. 


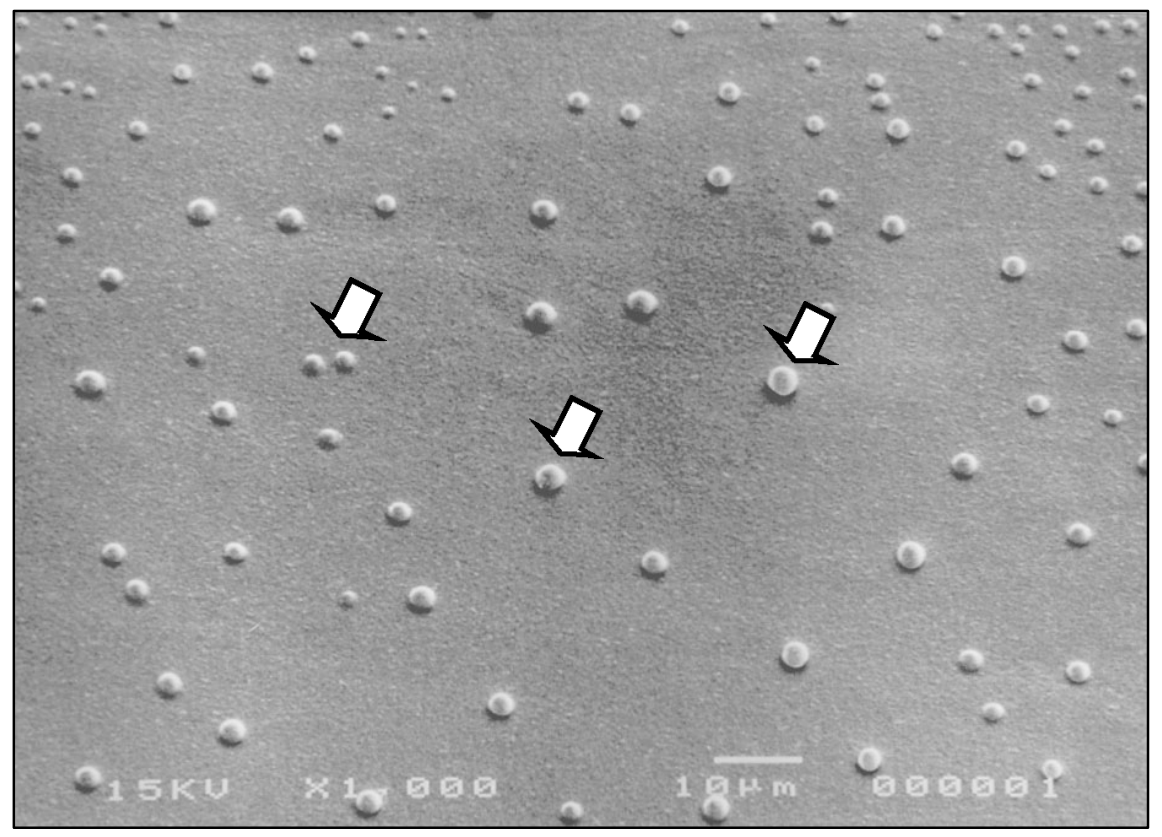

Figura 11C: Fotomicrografia eletrônica de varredura da réplica positiva da superfície dentinária no baseline, vista de topo. A resina epóxica não foi capaz de reproduzir detalhes, podendo-se notar a presença de inúmeras bolhas de diferentes tamanhos (setas).

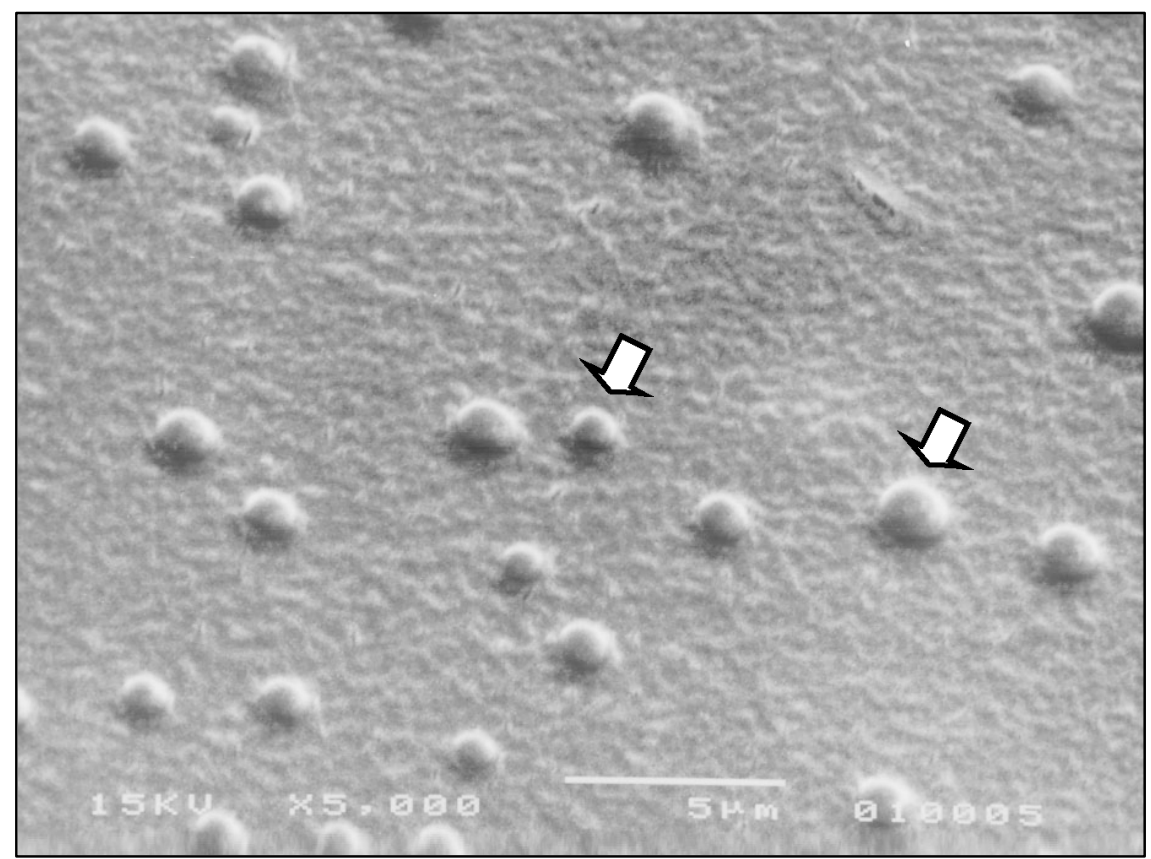

Figura 11D: Fotomicrografia eletrônica de varredura da réplica positiva da superfície dentinária no baseline, com maior aumento e inclinação de $50^{\circ}$, confirmando a presença de bolhas (setas). 


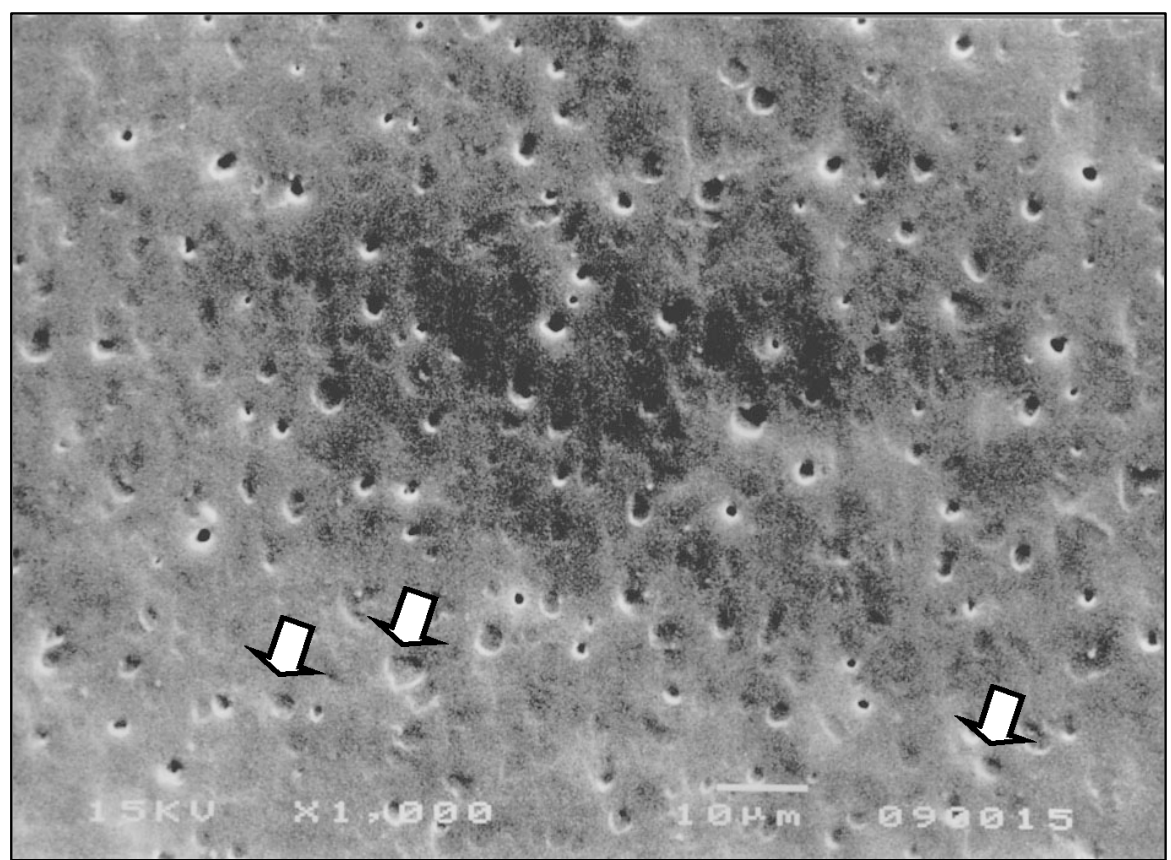

Figura 12A: Fotomicrografia eletrônica de varredura da réplica negativa da superfície dentinária de um paciente com grau de sensibilidade inicial de 8,6 ao estímulo sonda e 4,2 ao jato de ar. Podem ser observados túbulos dentinários de maior diâmetro e em grande quantidade. Algumas imagens podem ser interpretadas como sendo túbulos dentinários fechados (setas).

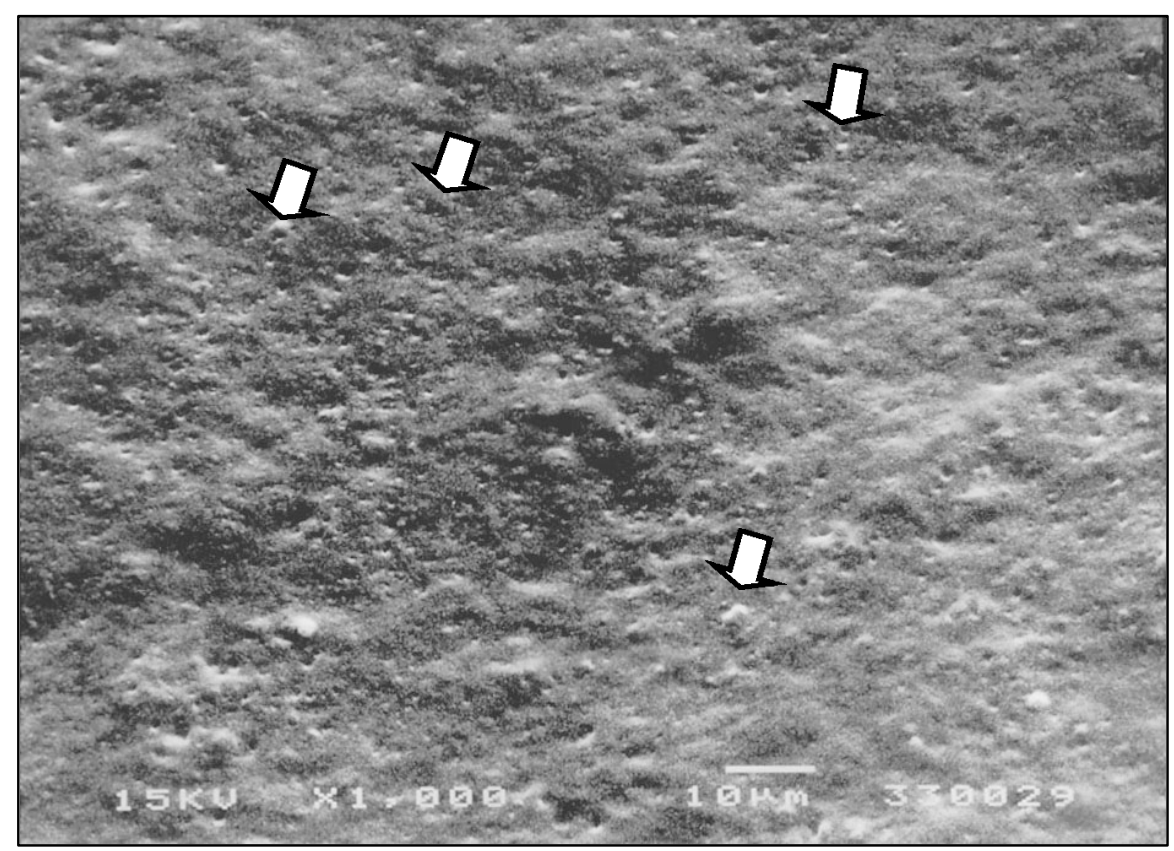

Figura 12B: Fotomicrografia eletrônica de varredura da réplica negativa da mesma superfície imediatamente após a quarta aplicação do Oxa-Gel ${ }^{\circledR}$, quando o paciente relatou significativa remissão da sensibilidade. Observa-se uma superfície onde os túbulos dentinários não estão mais totalmente visíveis. As setas indicam resquícios do agente dessensibilizante. 


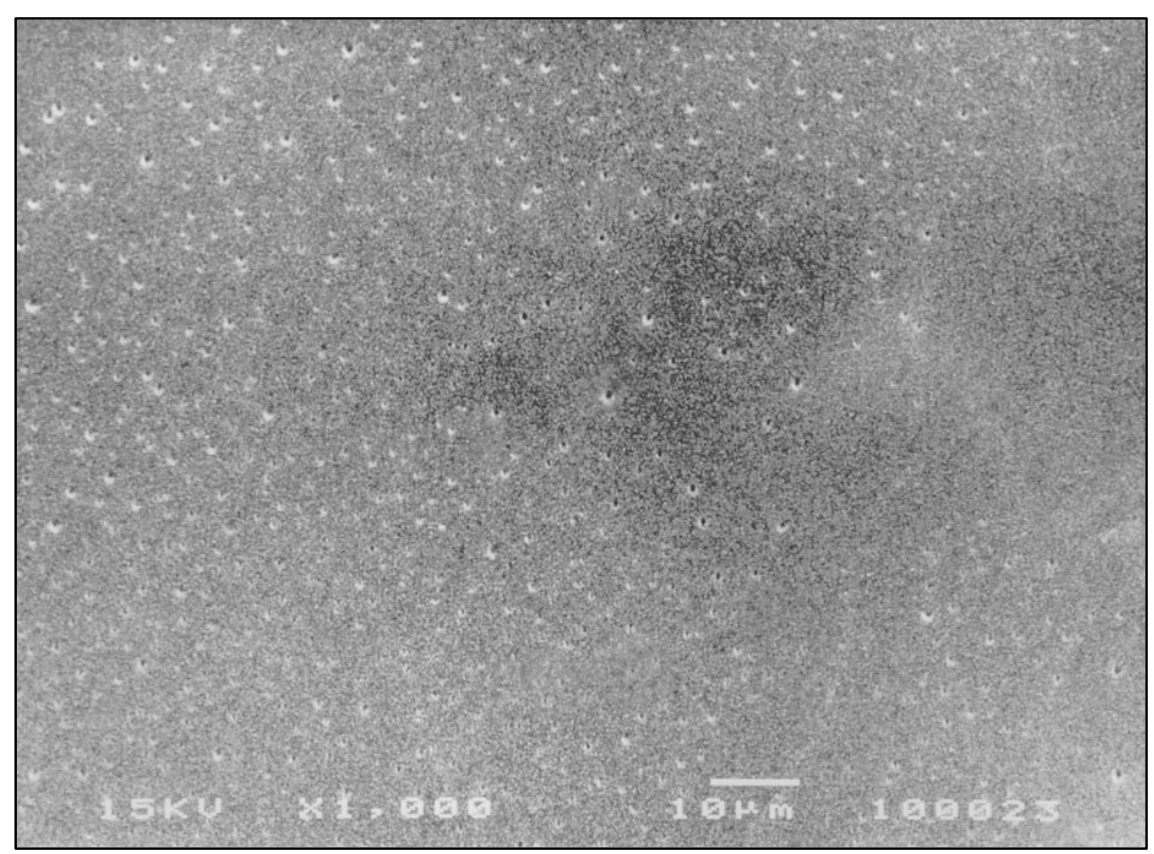

Figura 13A: Fotomicrografia eletrônica de varredura da réplica negativa da superfície dentinária de um paciente com grau de sensibilidade intenso ao estímulo sonda $(9,3)$ e moderado $(4,0)$ ao jato de ar no baseline. Pode-se observar uma grande quantidade de túbulos dentinários.

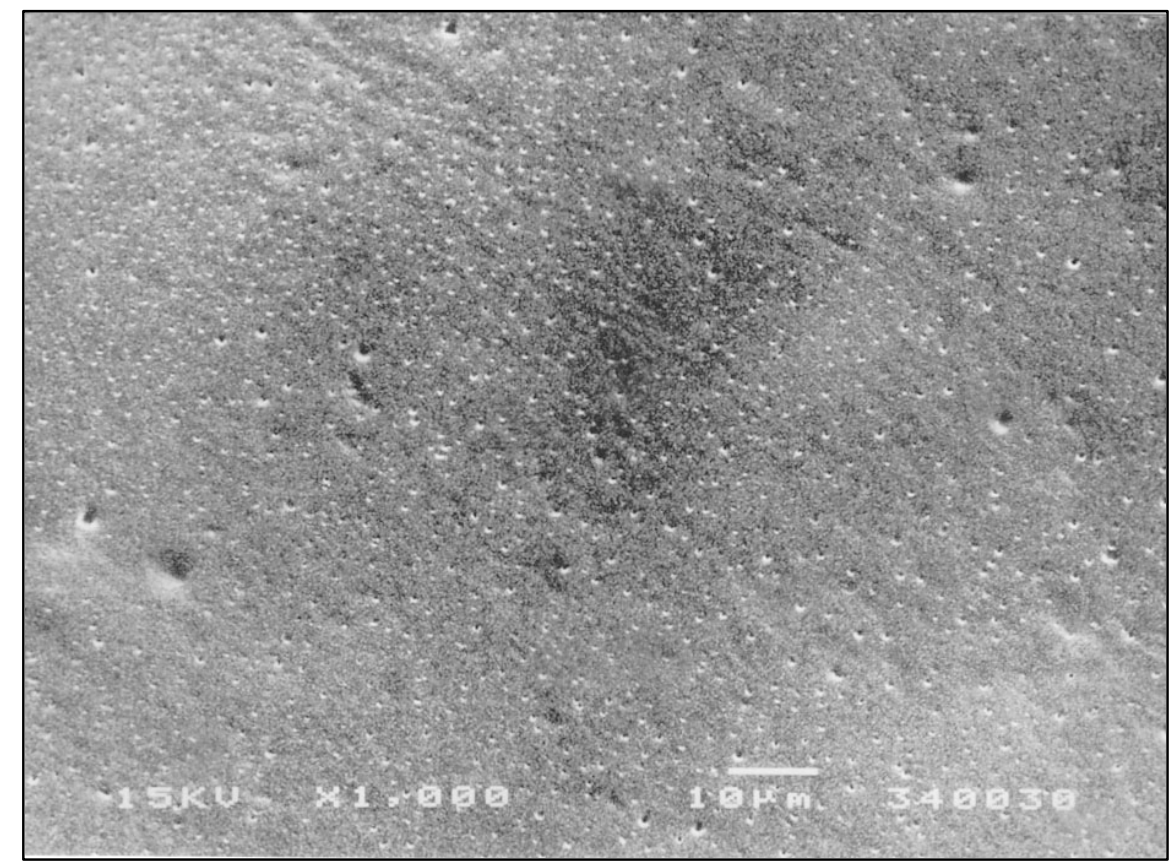

Figura 13B: Fotomicrografia eletrônica de varredura da réplica negativa representativa do final do tratamento com o agente dessensibilizante. Nota-se o mesmo padrão de imagem da figura anterior, embora o paciente tenha relatado diminuição do grau de sensibilidade para ambos os estímulos ( 0,8 para a sonda e 1,7 para o jato de ar). 


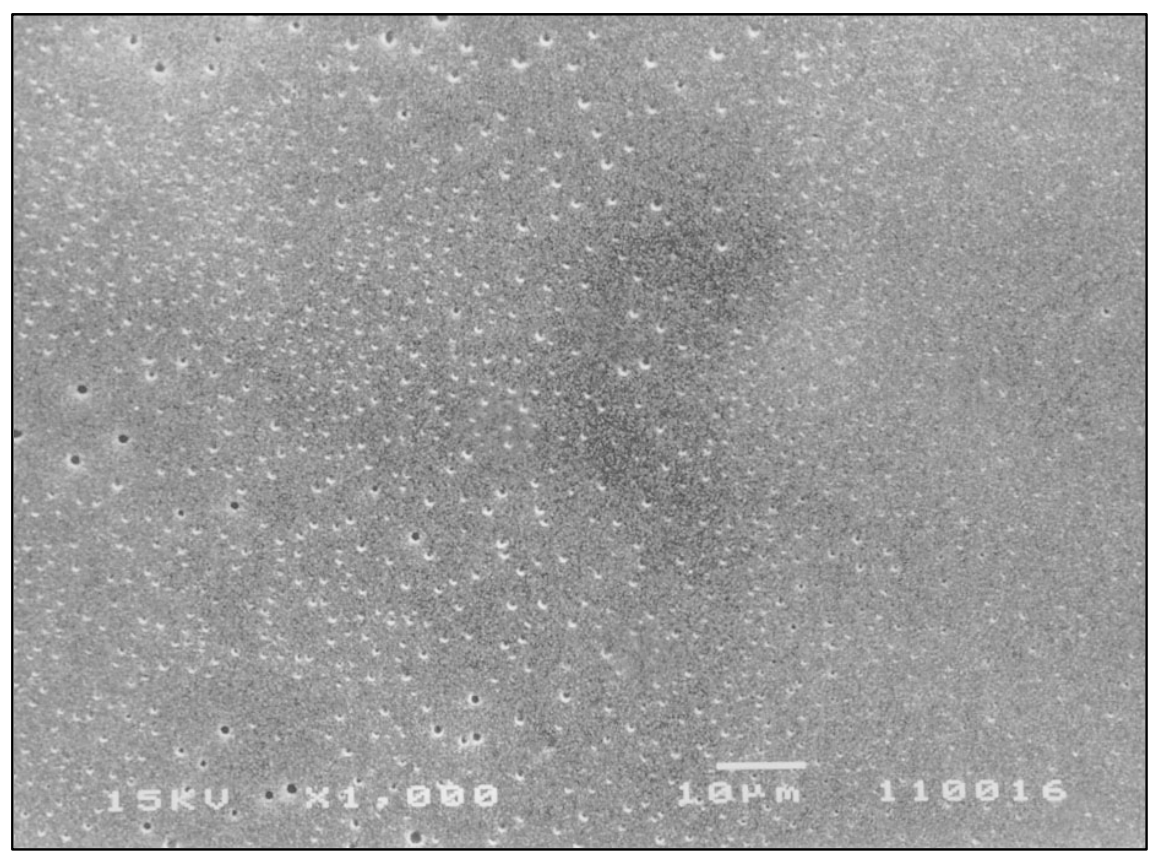

Figura 14A: Fotomicrografia eletrônica de varredura da réplica negativa de uma superfície dentinária com intensa quantidade tubular, com desconforto severo aos estímulos sonda $(6,0)$ e jato de ar $(5,8)$.

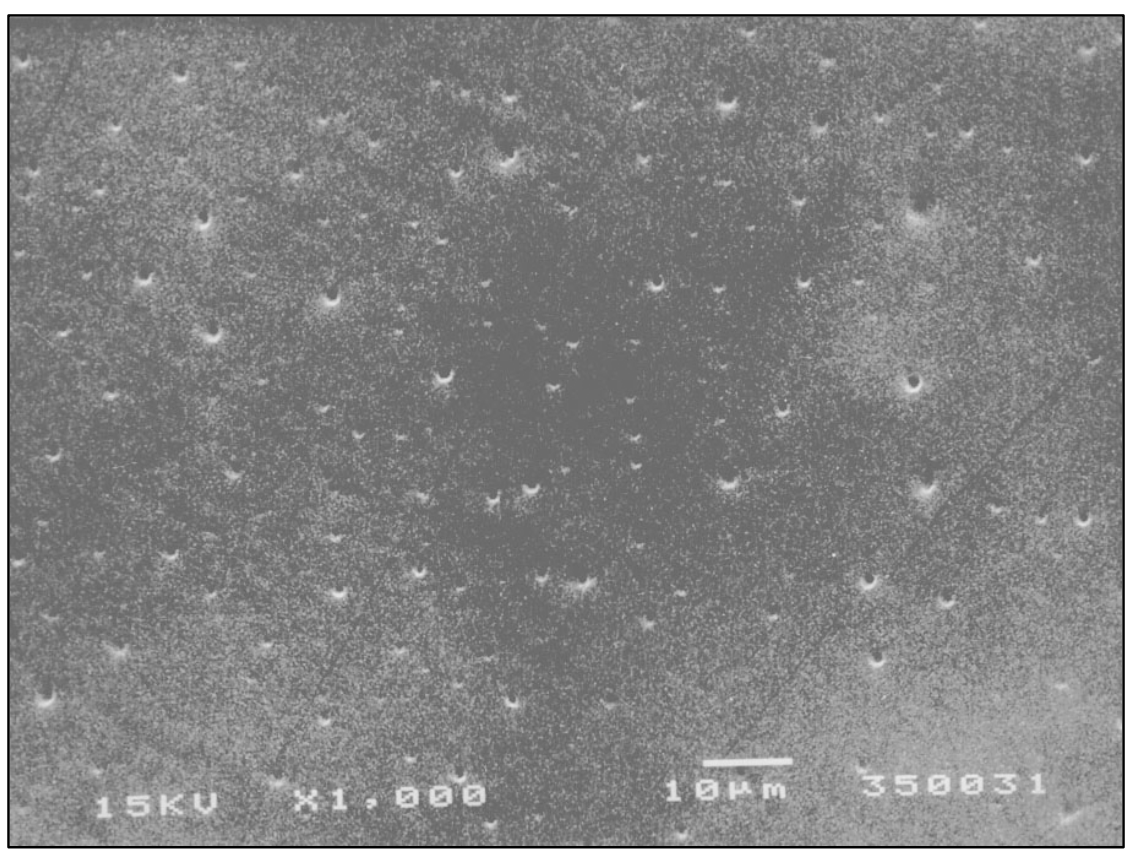

Figura 14B: Fotomicrografia eletrônica de varredura da réplica negativa da mesma superfície após o tratamento com o agente dessensibilizante, quando 0 paciente relatou remissão total do desconforto ao estímulo sonda e considerável melhora ao estímulo jato de ar $(1,8)$. Observa-se menor quantidade de túbulos dentinários, porém com maior diâmetro. 


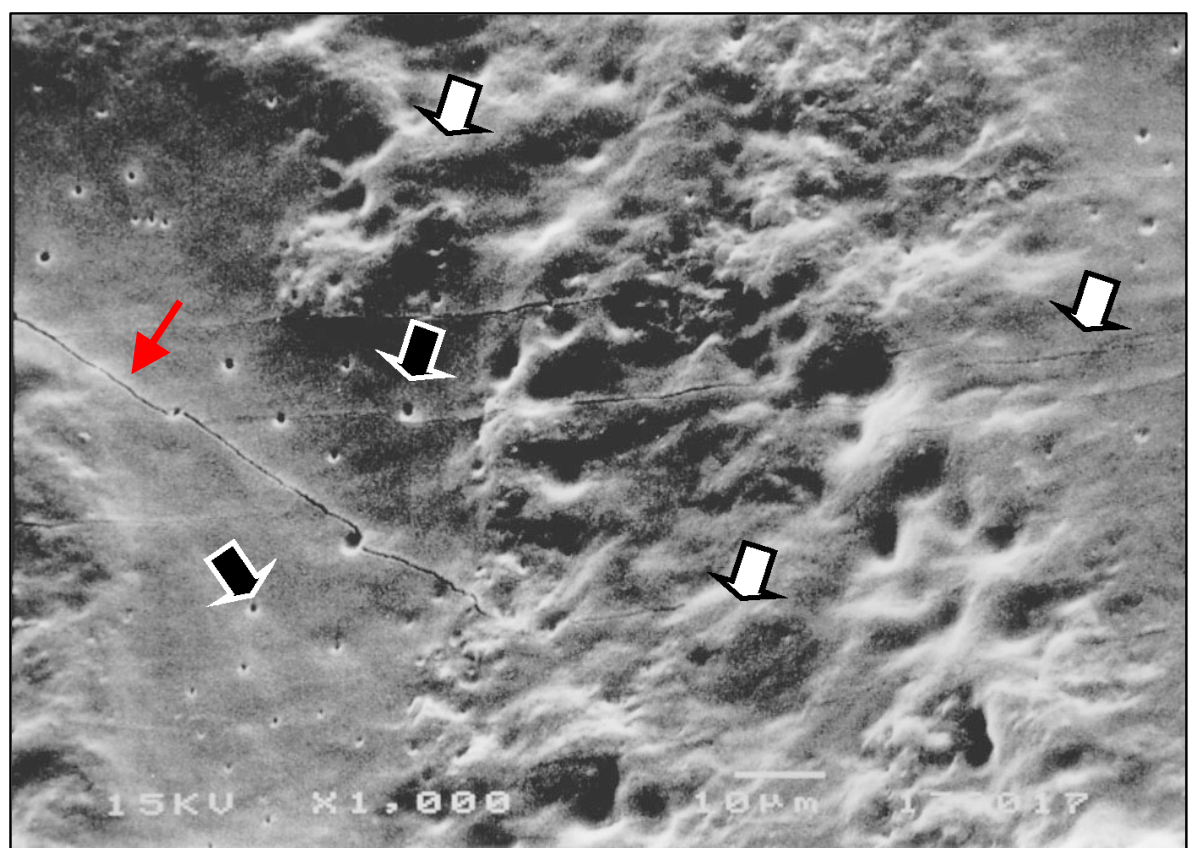

Figura 15A: Fotomicrografia eletrônica de varredura da réplica negativa da superfície dentinária com hipersensibilidade intensa $(7,2)$ ao estímulo sonda e extremamente intensa $(9,0)$ ao jato de ar, embora apresente áreas com total ausência de túbulos dentinários (setas brancas). As setas pretas indicam áreas de túbulos dentinários expostos com diferentes diâmetros. Nota-se a presença de uma fina trinca no espécime (seta vermelha).

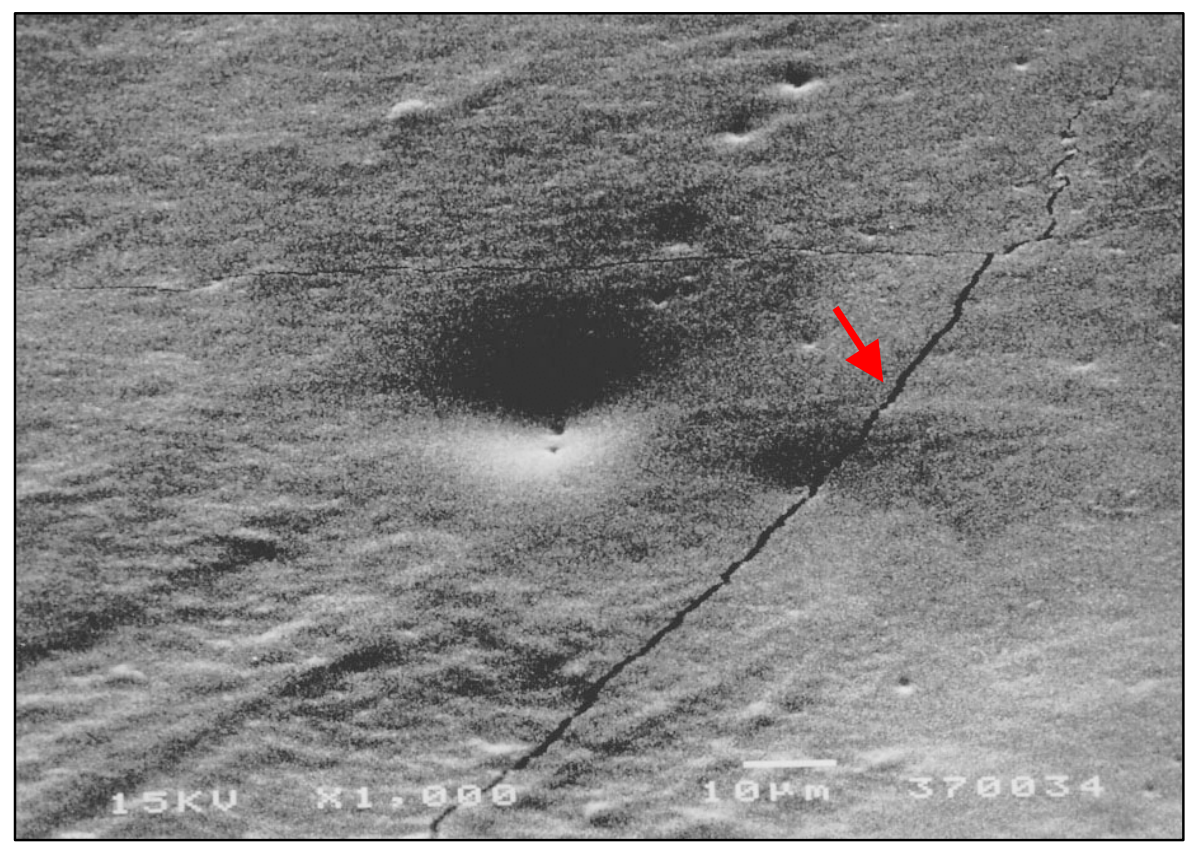

Figura 15B: Fotomicrografia eletrônica de varredura da réplica negativa da superfície anterior após o tratamento com Oxa-Gel ${ }^{\circledR}$. Nenhum túbulo dentinário pode ser claramente observado, coincidindo com a remissão do desconforto relatado pelo paciente $(0,6$ à sonda e 1,5 ao jato de ar). Observa-se a presença de uma trinca no espécime (seta vermelha). 


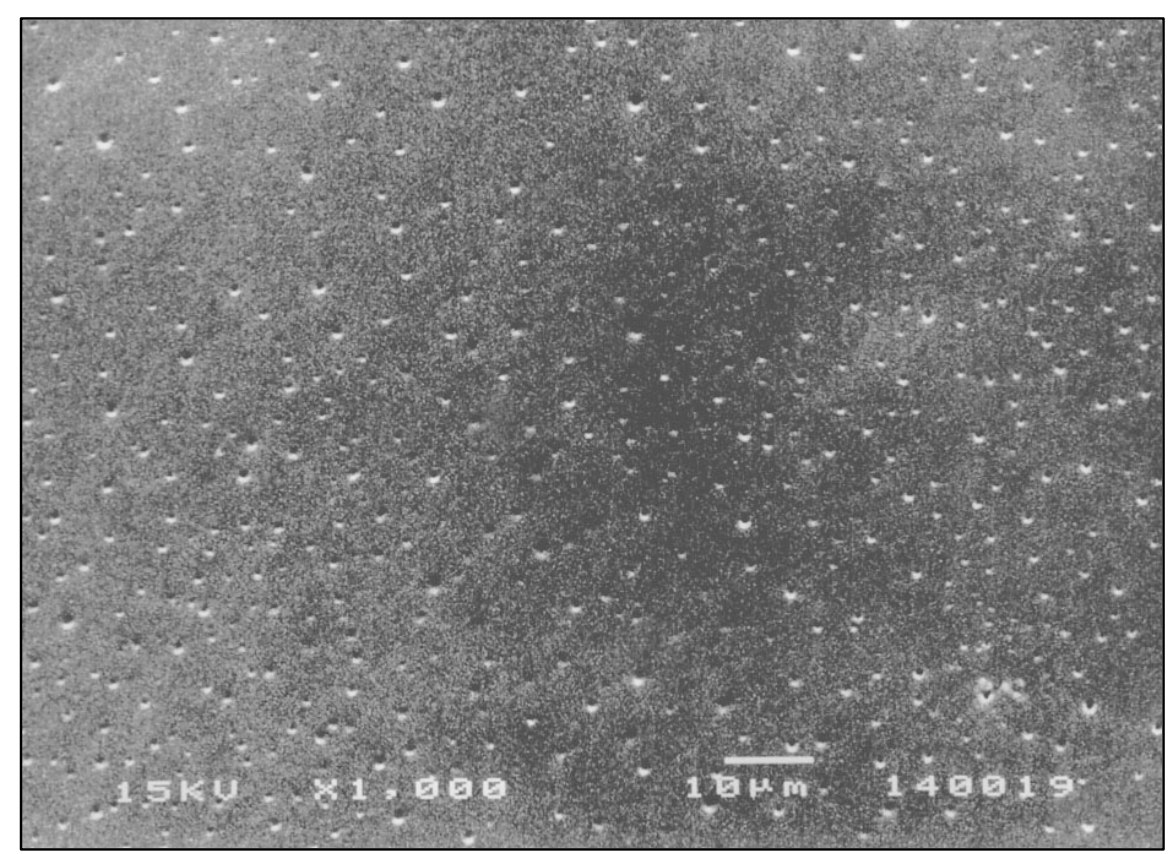

Figura 16A: Fotomicrografia eletrônica de varredura da réplica negativa de uma superfície dentinária com característica hiperestésica (intensa quantidade tubular), conforme relatado pelo paciente (grau 6,0 para a sonda e 7,8 para o jato de ar).

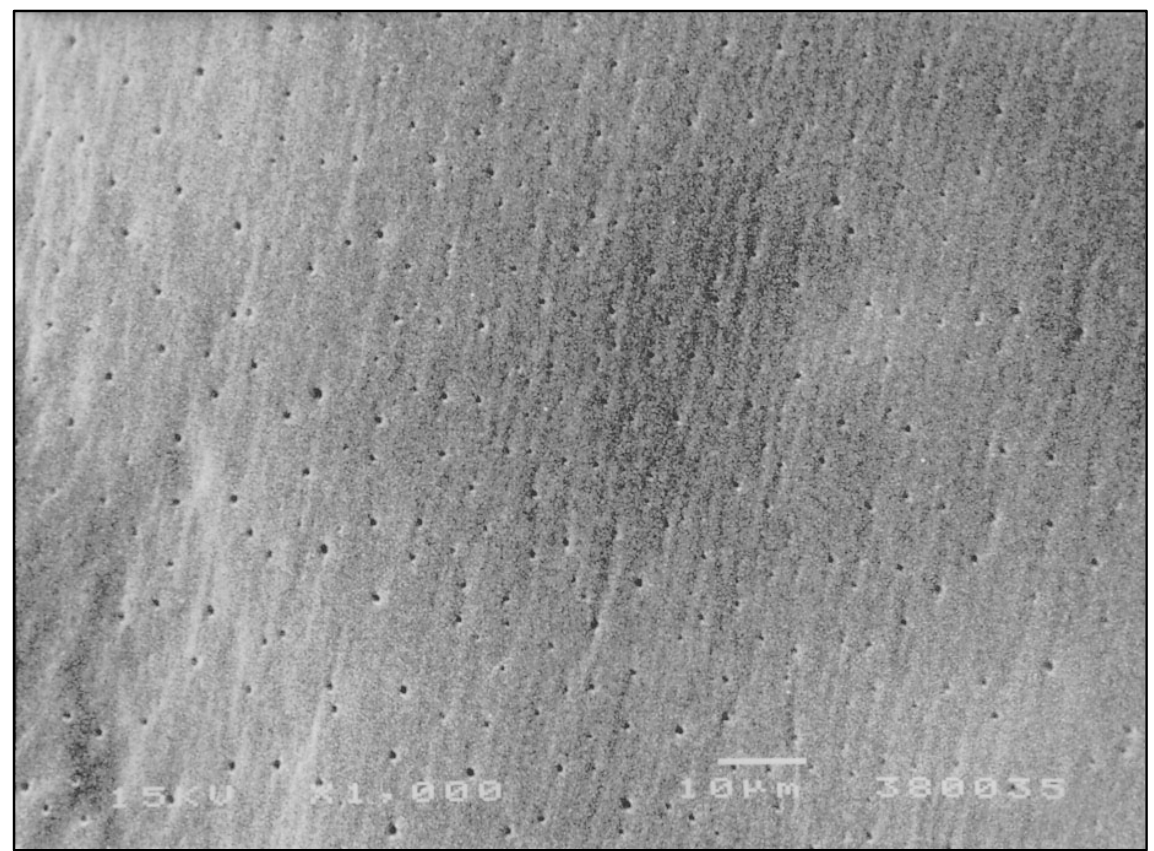

Figura 16B: Fotomicrografia eletrônica de varredura da réplica negativa da mesma superfície após o tratamento com o agente dessensibilizante. Nota-se que o padrão de quantidade tubular se mantém, embora o paciente tenha relatado grau de sensibilidade quase imperceptível aos estímulos sonda $(0,8)$ e jato de ar $(0,5)$. 


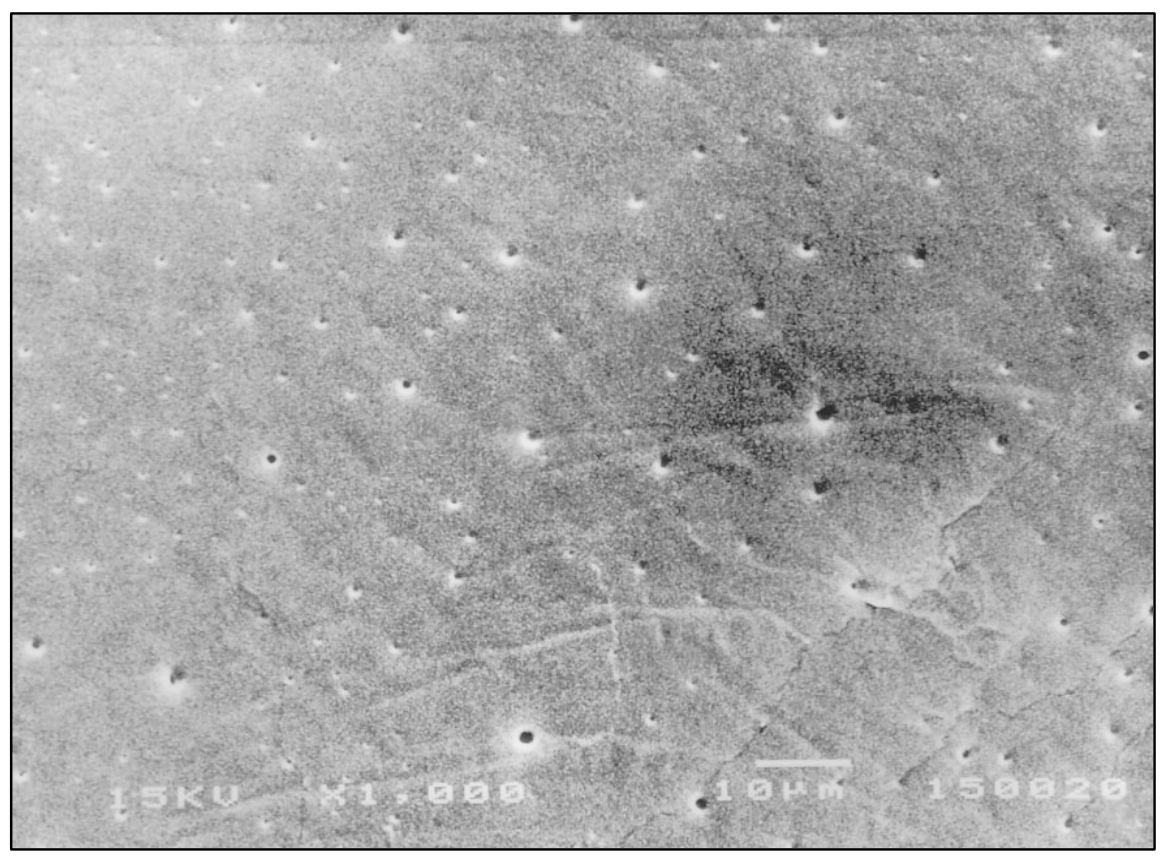

Figura 17A: Fotomicrografia eletrônica de varredura da réplica negativa mostrando grande quantidade de túbulos dentinários, condizentes com 0 desconforto extremamente intenso $(9,3)$ ao estímulo sonda e moderado $(4,0)$ ao estímulos ar, conforme relatado pelo paciente .

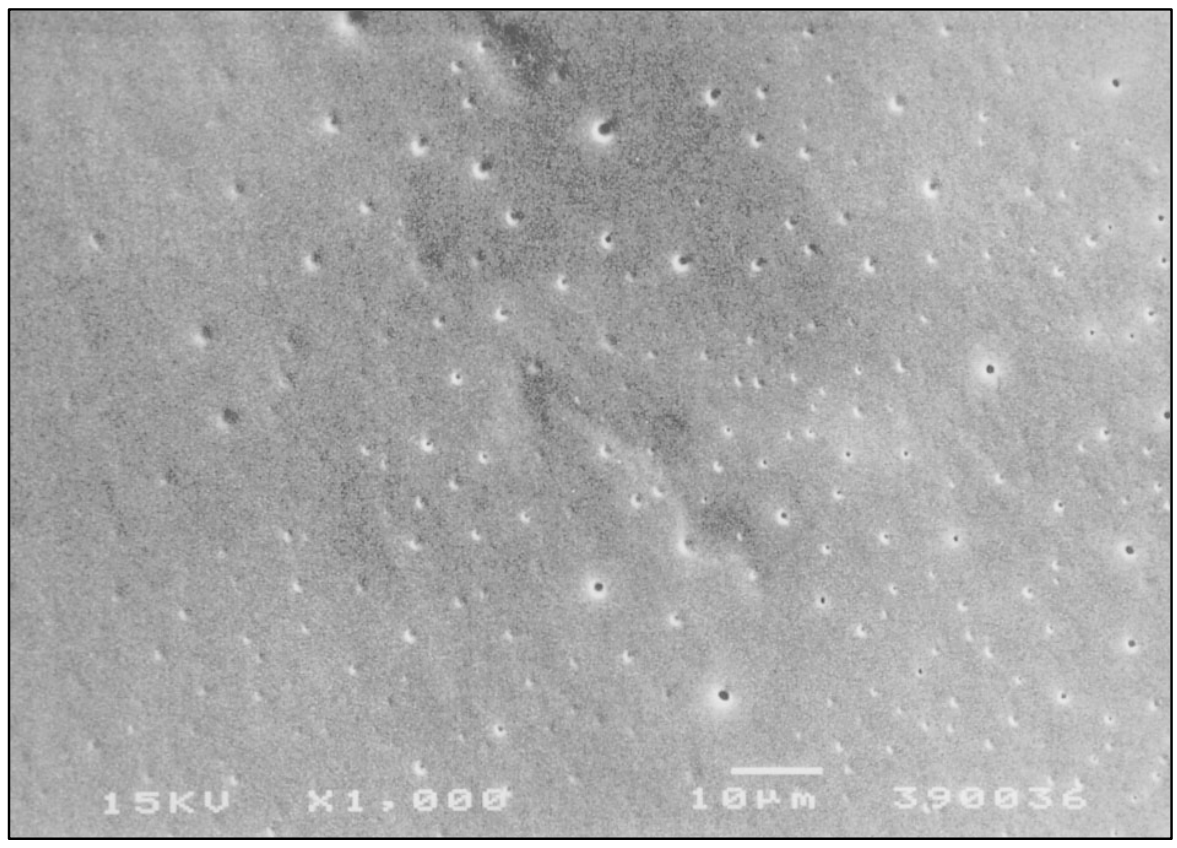

Figura 17B: Fotomicrografia eletrônica de varredura da réplica negativa da mesma superfície após o tratamento com oxalato de potássio. Os túbulos dentinários aparecem em grande número, ainda que o paciente tenha relatado diminuição do desconforto a ambos os estímulos (0,8 à sonda e 1,7 ao jato de ar). 


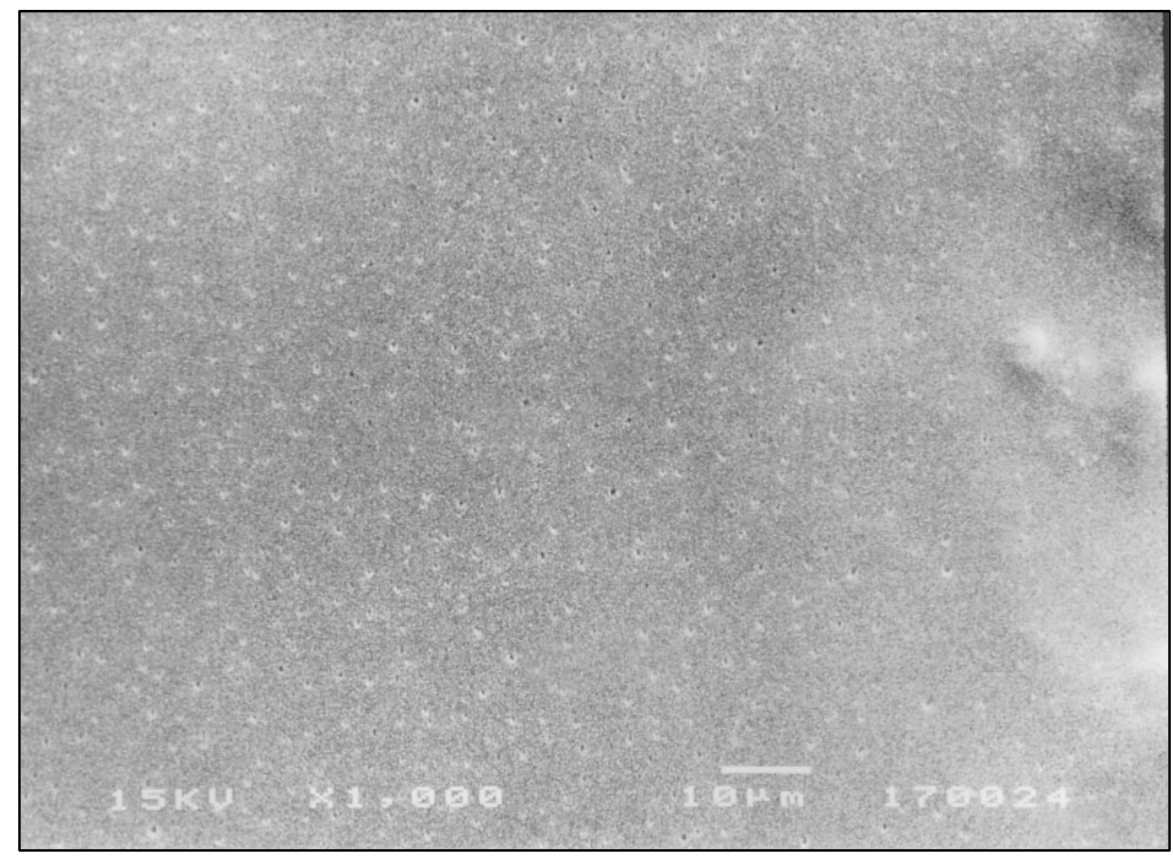

Figura 18A: Fotomicrografia eletrônica de varredura da réplica negativa característica de uma dentina hiperestésica (grau 10,0 ao estímulo sonda e 9,0 ao estímulo jato de ar), devido à grande quantidade de túbulos dentinários, embora de diâmetro reduzido.

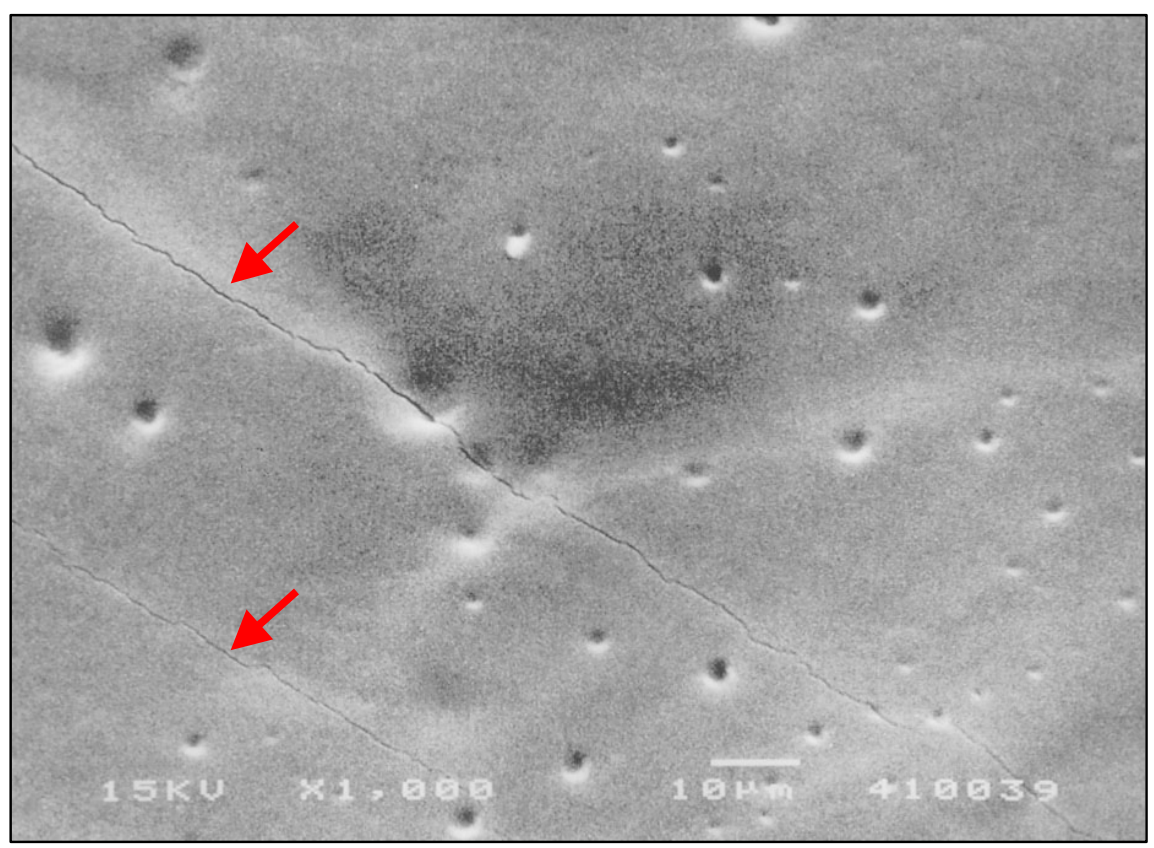

Figura 18B: Fotomicrografia eletrônica de varredura da réplica negativa da mesma superfície após o tratamento. Nota-se a diminuição considerável do número de túbulos dentinários, agora com diâmetros maiores, sendo relatado um desconforto leve $(5,2)$ somente ao estímulo sonda. Finas trincas estão presentes (setas vermelhas). 


\section{GRUPO 2}

Com relação ao Grupo 2, que não recebeu qualquer tratamento, o objetivo foi acompanhar a evolução de dentes classificados como hiperestésicos ao longo de 4 semanas, período em que poderia ocorrer remissão expontânea da dor. Participaram desse grupo somente 4 pacientes, sendo 2 do gênero feminino e 2 do gênero masculino, com idades entre 30 e 42 anos, os quais estavam cientes de que não receberiam tratamento para a hiperestesia dentinária durante a pesquisa. Foram selecionados 7 dentes caninos e pré-molares, com grau de sensibilidade mínimo de $3 \mathrm{~cm}$ aos estímulos sonda ou ar, de acordo com a EVA.

A Figura 5.2, abaixo, mostra a relação de pacientes, dentes, grau de sensibilidade aos estímulos sonda e ar antes e depois do período de 4 semanas, bem como a relação dos espécimes (réplicas negativas).

\begin{tabular}{|c|c|c|c|c|c|c|c|}
\hline \multirow{2}{*}{$\begin{array}{l}\text { PAC. } \\
\text { Ficha no }\end{array}$} & \multirow[t]{2}{*}{ DENTE } & \multirow[t]{2}{*}{ AMOSTR } & \multicolumn{2}{|c|}{ GS INICIAL } & \multirow[t]{2}{*}{ AMOSTR } & \multicolumn{2}{|c|}{ GS FINAL } \\
\hline & & & SONDA & AR & & SONDA & AR \\
\hline 12 & 14 & 51 & 4,5 & 5,8 & 75 & 2,7 & 3,6 \\
\hline 12 & 45 & 52 & 3,6 & 3,8 & 76 & 3,4 & 5,7 \\
\hline 13 & 13 & 53 & 3,5 & 3,3 & 77 & 5,9 & 2,8 \\
\hline 13 & 24 & 54 & 3,5 & 3,8 & 78 & 1,0 & 0,6 \\
\hline 14 & 33 & 55 & 5,7 & 0,0 & 79 & 4,3 & 0,0 \\
\hline 14 & 34 & 56 & 7,8 & 1,7 & 80 & 3,7 & 1,3 \\
\hline 15 & 44 & 57 & 7,0 & 3,4 & 81 & 5,8 & 2,3 \\
\hline
\end{tabular}

Figura 5.2: Relação de Pacientes, Dentes, Grau de Sensibilidade e Espécimes do Grupo 2

A Figuras 19 a 25 (págs. 126 a 132) correspondem às fotomicrografias das réplicas negativas obtidas a partir da moldagem das superfícies dentinárias hiperestésicas do Grupo 2 antes (A) e após o período de 4 semanas (B). 
A Figura 19A representa a fotomicrografia da réplica negativa de uma superfície dentinária com grau de sensibilidade classificado como moderado $(4,5)$ e levemente forte $(5,8)$ para os estímulos sonda e jato de ar no baseline, respectivamente. Túbulos dentinários abertos ou parcialmente abertos, com diferentes diâmetros estão presentes, caracterizando, assim, a dentina hiperestésica. Após 4 semanas, a réplica negativa (Figura 19B) revelou uma superfície recoberta com uma camada amorfa, não definida, o que provavelmente resultou na diminuição do grau de sensibilidade relatado pelo paciente $(2,7$ para 0 estímulo sonda e 3,6 para o estímulo ar) naquele momento.

A fotomicrografia apresentada na Figura 20A revela uma superfície em que os túbulos dentinários podem ser considerados praticamente ausentes. O grau de sensibilidade relatado pelo paciente foi classificado como leve para ambos os estímulos. Decorrido o período de 4 semanas, o paciente relatou um aumento sutil da sensibilidade somente ao estímulo ar, classificado, então, como sensibilidade levemente forte $(5,7)$. Pode-se observar, então, inúmeros túbulos dentinários sobre a mesma superfície (Figura 20B).

Características semelhantes podem ser observadas na figura seguinte (21A), ou seja, poucos túbulos dentinários caracterizando a dentina com grau de sensibilidade leve para ambos os estímulos (3,5 à sonda e 3,3 ao jato de ar). A Figura 21B, quando comparada ao baseline, evidencia maior quantidade de túbulos dentinários, o que justifica, talvez, o aumento do grau de sensibilidade, principalmente ao estímulo sonda $(5,9)$, então classificado como levemente forte. Nota-se, ainda, a presença de trincas no material de moldagem (setas vermelhas).

Na Figura 22A, podem ser vistos poucos túbulos dentinários apresentando grande diâmetro em sua maioria. Conforme relato do paciente, classificou-se o 
grau de sensibilidade como leve aos estímulos sonda $(3,5)$ e jato de ar $(3,8)$. Curiosamente, após 4 semanas, o paciente relatou um grau de sensibilidade quase imperceptível à sonda $(1,0)$ e ausente ao estímulo ar $(0,6)$, embora a superfície apresentasse uma grande quantidade de túbulos dentinários com diâmetros reduzidos (Figura 22B).

A Figura 23A apresenta a fotomicrografia de um paciente com grau de sensibilidade classificado como levemente forte $(5,7)$ somente ao estímulo sonda, sendo notados túbulos dentinários de diferentes diâmetros. Na fotomicrografia seguinte (Figura 23B), os túbulos dentinários continuam presentes na mesma intensidade, mas com diâmetros similares. A melhora do desconforto ao estímulo sonda foi quase que mínima, sendo classificada pelo paciente como moderado $(4,3)$ ao final de 4 semanas.

Uma diminuição considerável do grau de sensibilidade, coincidente com a diminuição na quantidade dos túbulos dentinários, pode ser observada nas Figuras 24A e 24B. Após 4 semanas, $O$ paciente relatou diminuição do desconforto ao estímulo sonda, que passou da classificação de intenso $(7,8)$ com relação à sonda e quase imperceptível $(1,7)$ ao jato de ar no baseline, a leve $(3,7)$ para a sonda e quase imperceptível $(1,3)$ ao jato de ar. Quando se observam os túbulos dentinários presentes na Figura 24A, nota-se que, além da diminuição na quantidade, os mesmos apresentam-se com menor diâmetro na Figura 24B. As setas brancas indicam, ainda, a presença de partículas de origem desconhecida, as quais podem ter contribuído para a diminuição da sensibilidade e que, quando não removidas no processo de moldagem, causaram defeitos na superfície do molde (seta preta).

As Figuras 25A e 25B evidenciam situação semelhante, ou seja, diminuição na quantidade de túbulos dentinários após o período de 4 semanas, 
quando o paciente relatou uma pequena diminuição no desconforto a ambos estímulos, ou seja, de intenso $(7,0)$ à sonda e leve $(3,4)$ ao jato de ar para levemente forte $(5,8)$ à sonda e muito leve $(2,3)$ ao jato de ar. 


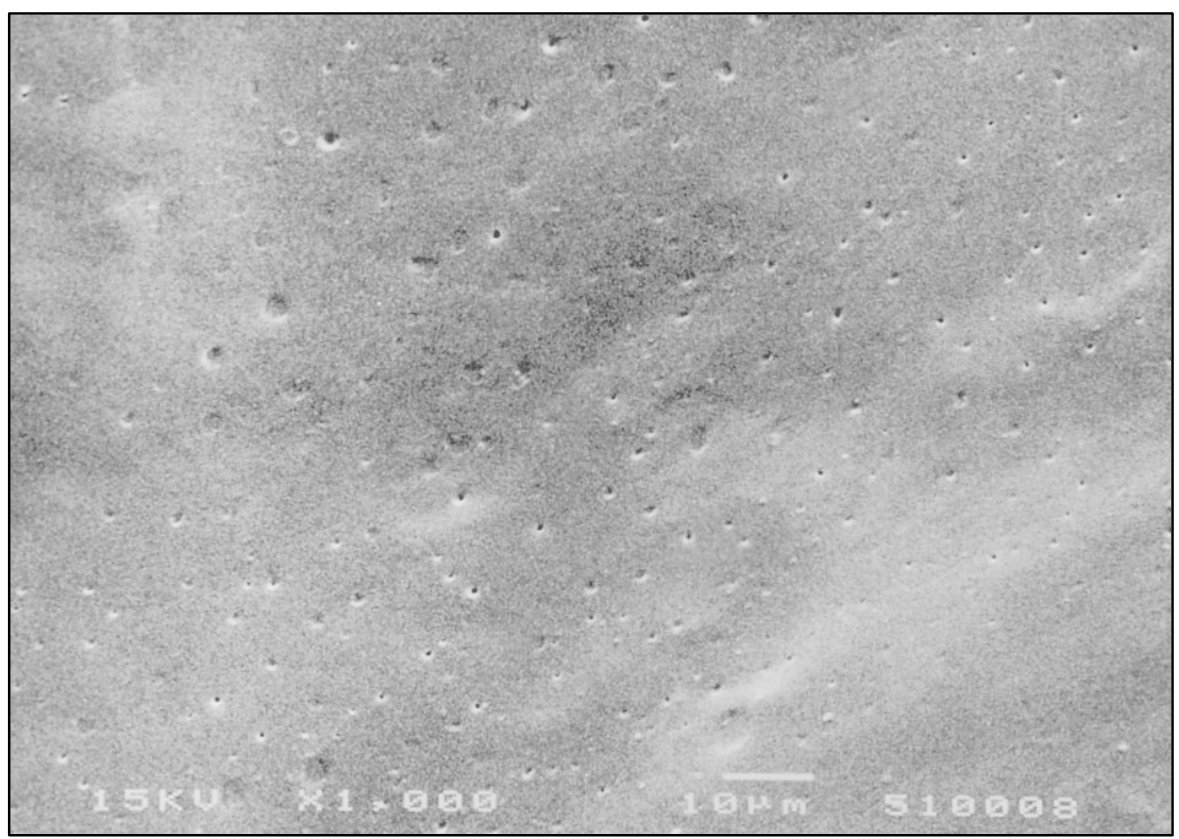

Figura 19A: Fotomicrografia eletrônica de varredura da réplica negativa de uma superfície dentinária com grau de sensibilidade moderado (4,50 ao estímulo sonda e levemente forte $(5,8)$ ao estímulo ar. Observa-se a presença de túbulos dentinários abertos ou parcialmente abertos, com diferentes diâmetros.

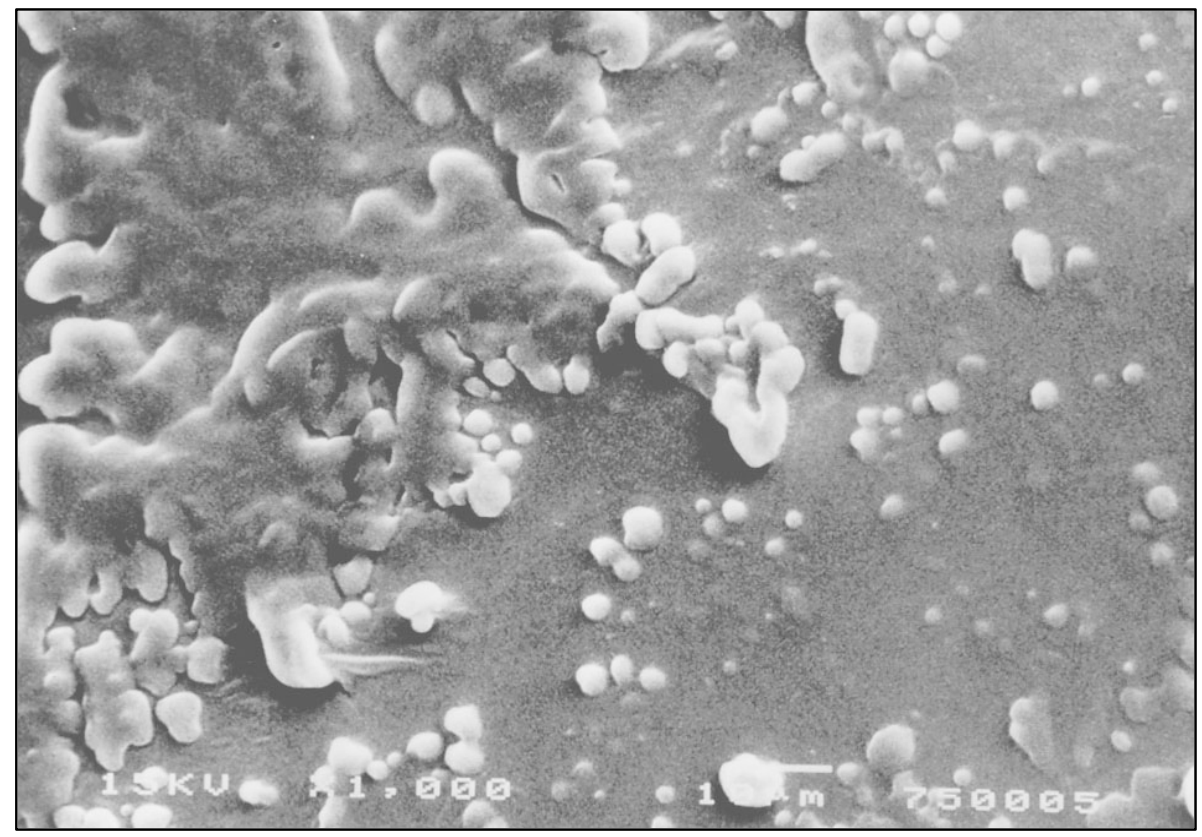

Figura 19B: Fotomicrografia eletrônica de varredura da réplica negativa da mesma superfície após o período de 4 semanas sem tratamento. A imagem revela uma superfície recoberta com uma camada amorfa, não definida, a qual pode ter contribuído para a diminuição do grau de sensibilidade relatado pelo paciente no momento (2,7 à sonda e 3,6 ao jato de ar). 


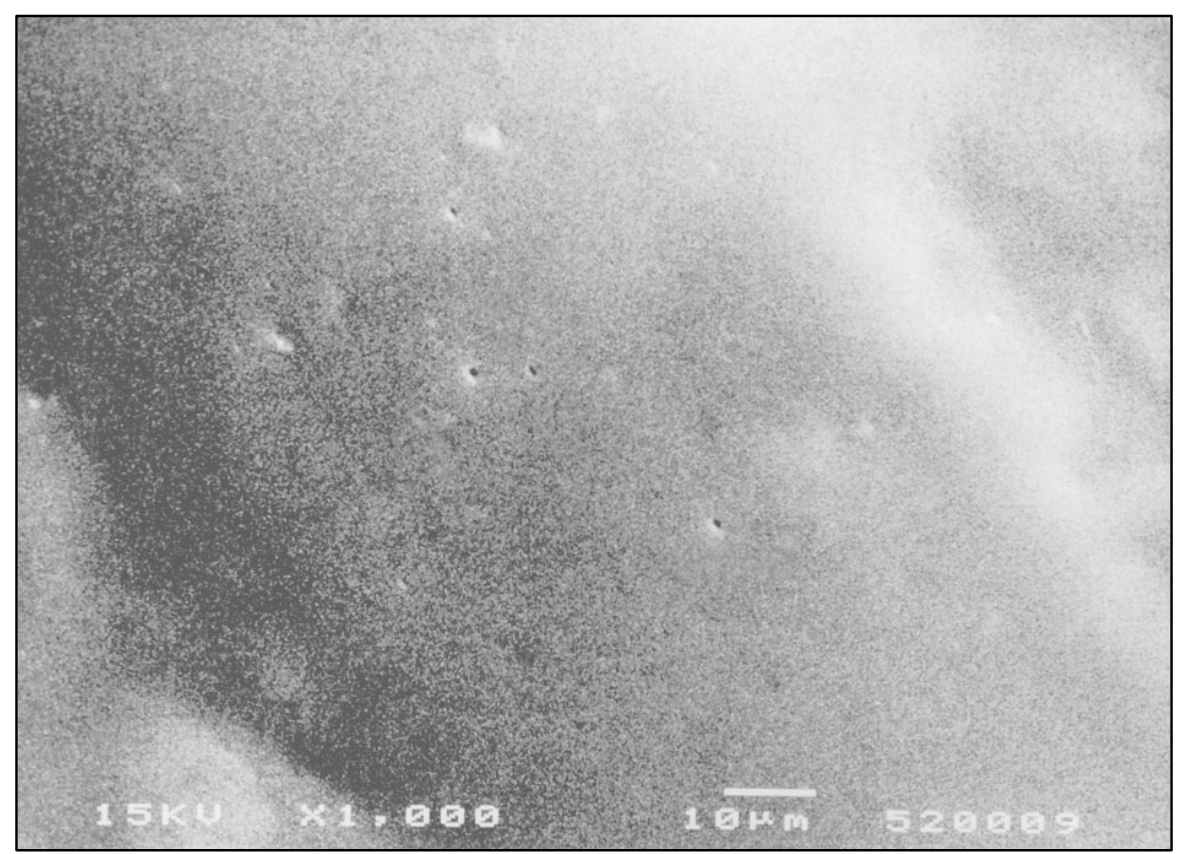

Figura 20A: Fotomicrografia eletrônica de varredura representativa da réplica negativa de uma superfície praticamente isenta de túbulos dentinários, com grau de sensibilidade leve $(3,6$ e 3,8$)$ para os estímulos sonda e jato de ar, respectivamente.

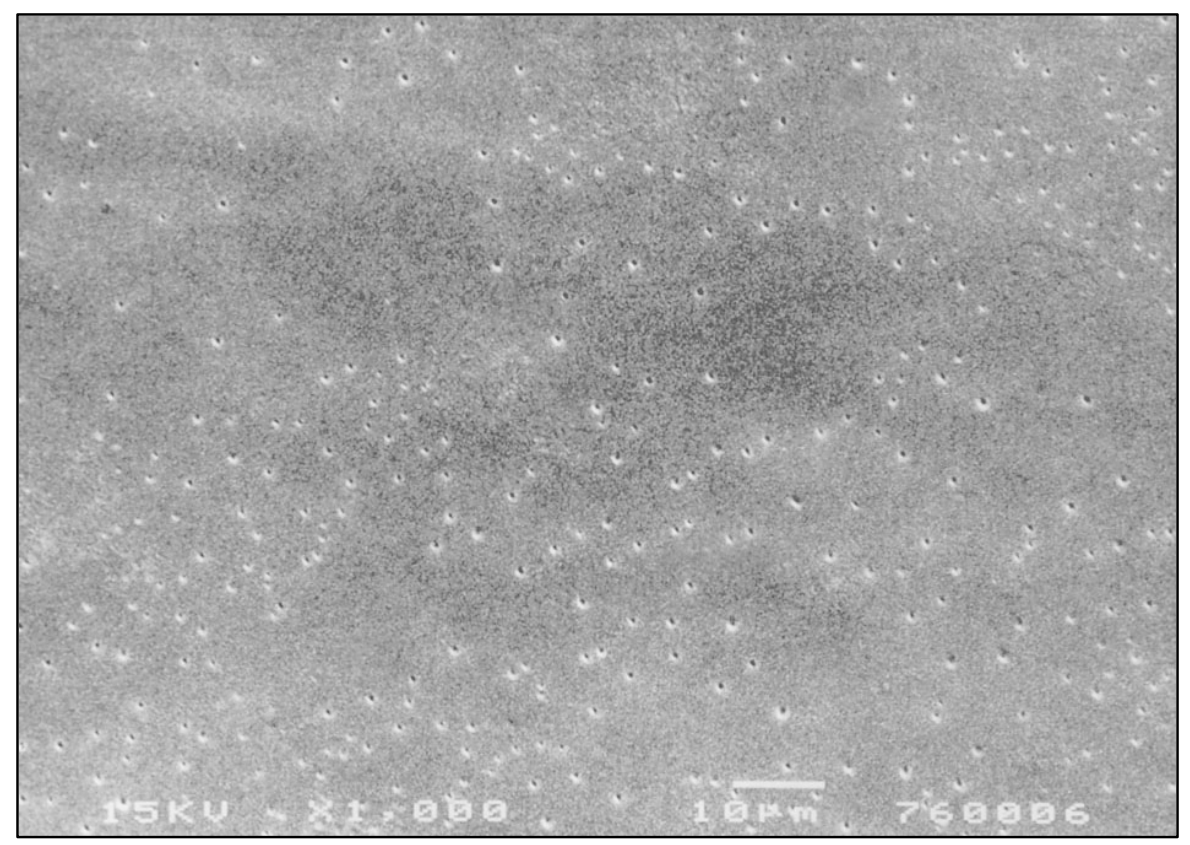

Figura 20B: Fotomicrografia eletrônica de varredura da réplica negativa após o período de 4 semanas, quando o paciente relatou um sutil aumento da sensibilidade somente ao estímulo ar $(5,7)$. Pode-se observar uma grande quantidade de túbulos dentinários sobre a mesma superfície. 


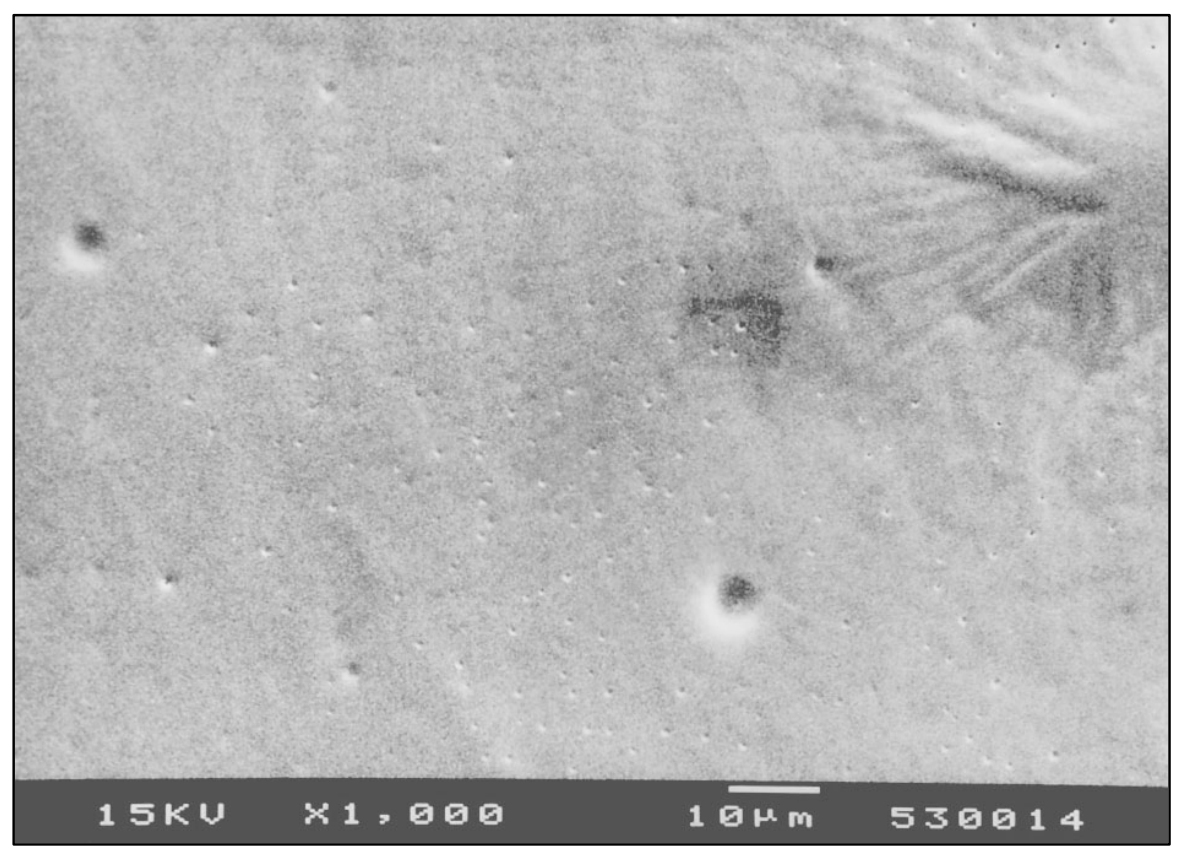

Figura 21A: Fotomicrografia eletrônica de varredura da réplica negativa em que se observam poucos túbulos dentinários, caracterizando a dentina com grau de sensibilidade leve $(3,5$ e 3,3$)$ para ambos os estímulos.

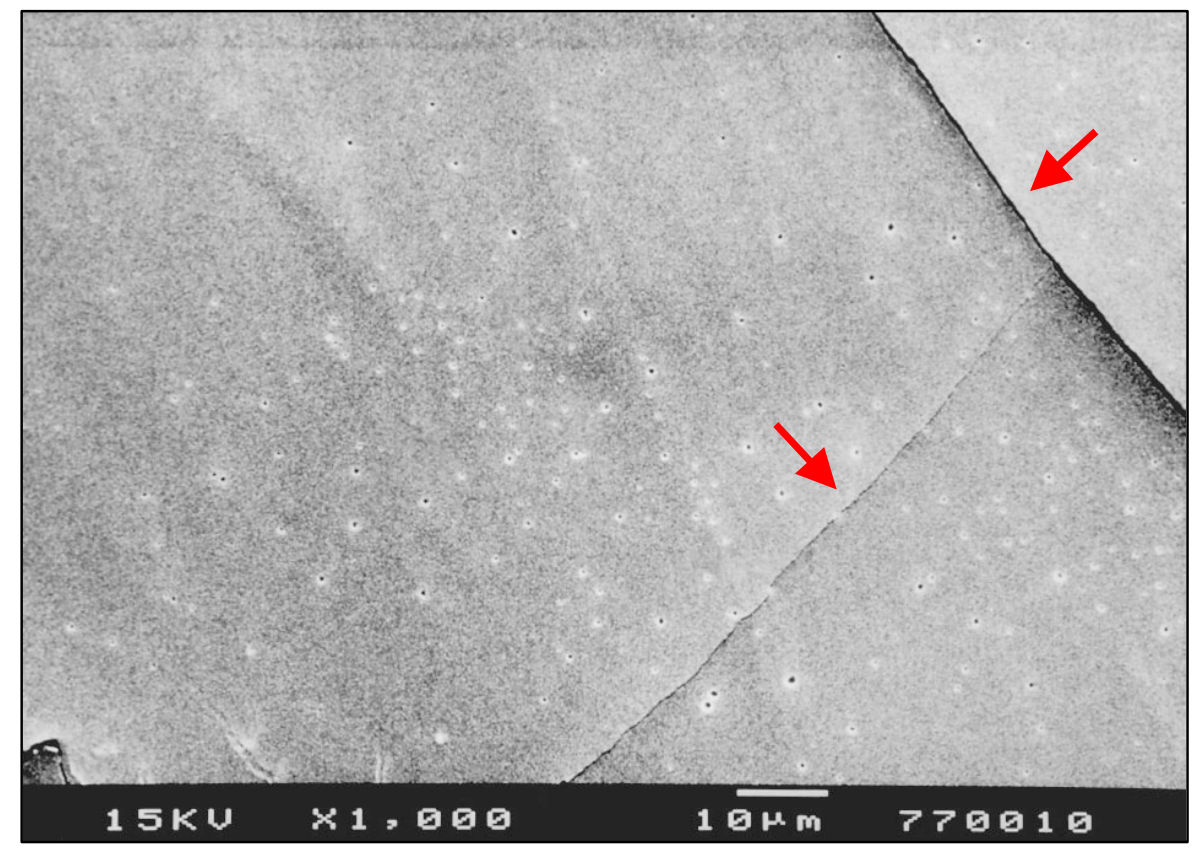

Figura 21B: Fotomicrografia eletrônica de varredura da réplica negativa, revelando maior quantidade de túbulos dentinários se comparado ao baseline. Houve um aumento do grau de sensibilidade ao estímulo sonda $(5,9)$ e uma mínima diminuição com relação ao jato de ar $(2,8)$. As setas vermelhas indicam trincas no espécime. 


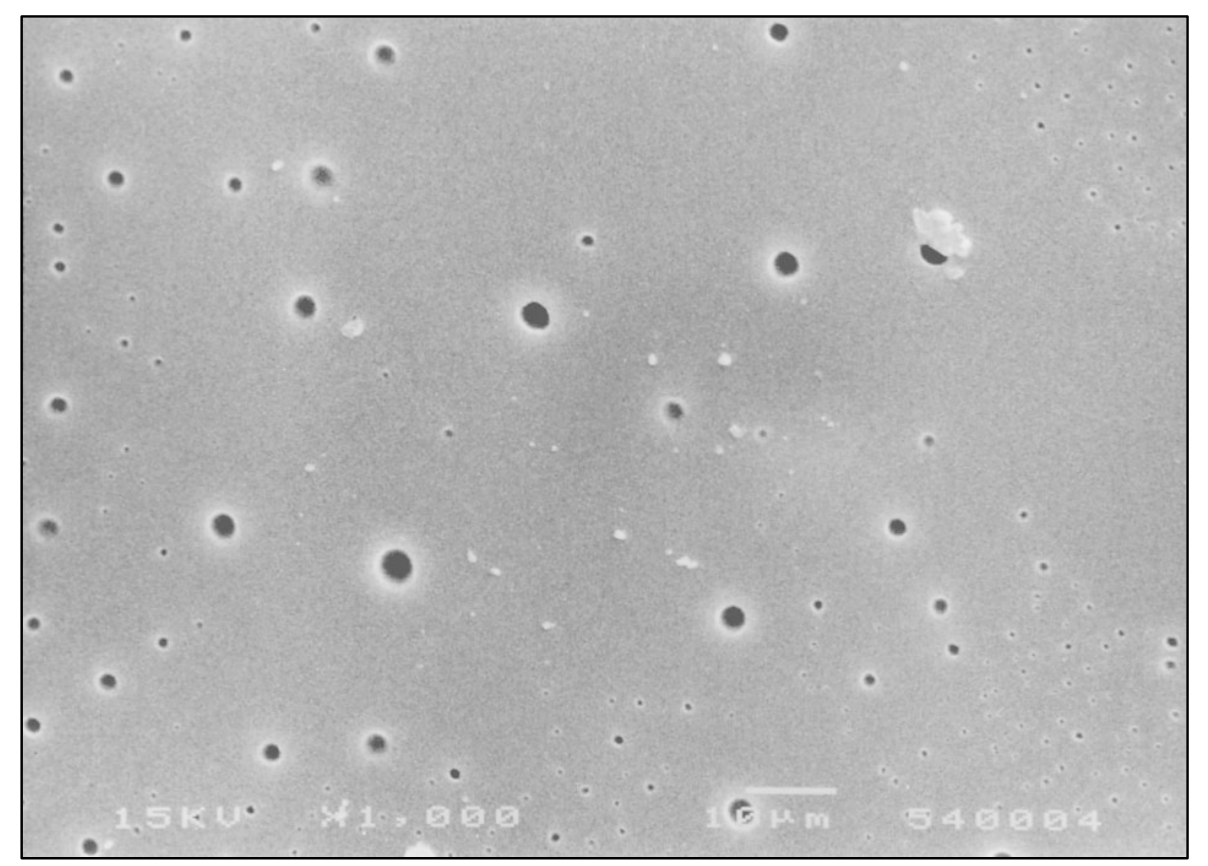

Figura 22A: Fotomicrografia eletrônica de varredura da réplica negativa em que se observam poucos túbulos dentinários, apresentando, em sua maioria, grande diâmetro. O grau de sensibilidade foi classificado como leve para ambos os estímulos.

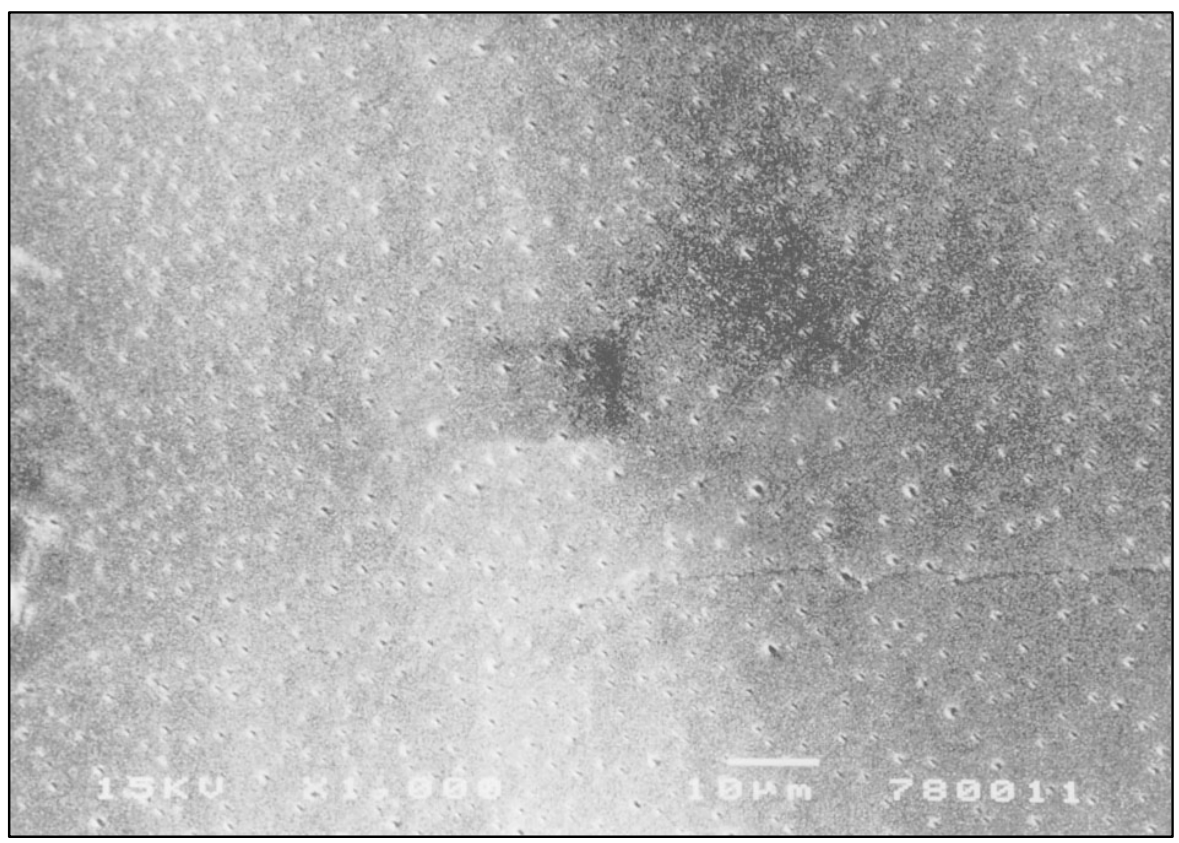

Figura 22B: Fotomicrografia eletrônica de varredura da réplica negativa da mesma superfície após 4 semanas sem tratamento, quando o paciente relatou ausência de desconforto ao estímulo ar $(0,6)$ e quase imperceptível $(1,0)$ ao estímulo sonda, embora a superfície apresente grande quantidade de túbulos dentinários de pequeno diâmetro. 


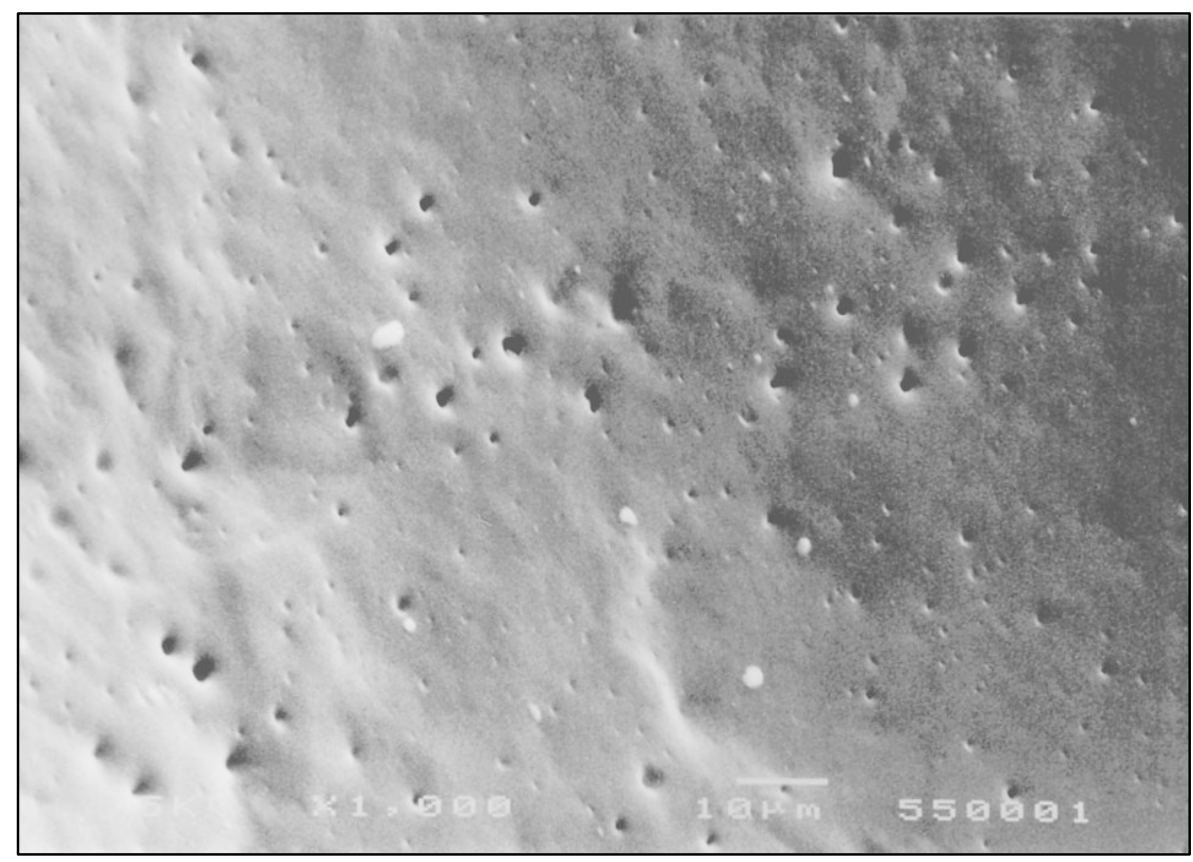

Figura 23A: Fotomicrografia eletrônica de varredura da réplica negativa na qual notam-se túbulos dentinários de diferentes diâmetros e grau de sensibilidade levemente forte $(5,7)$ somente ao estímulo sonda.

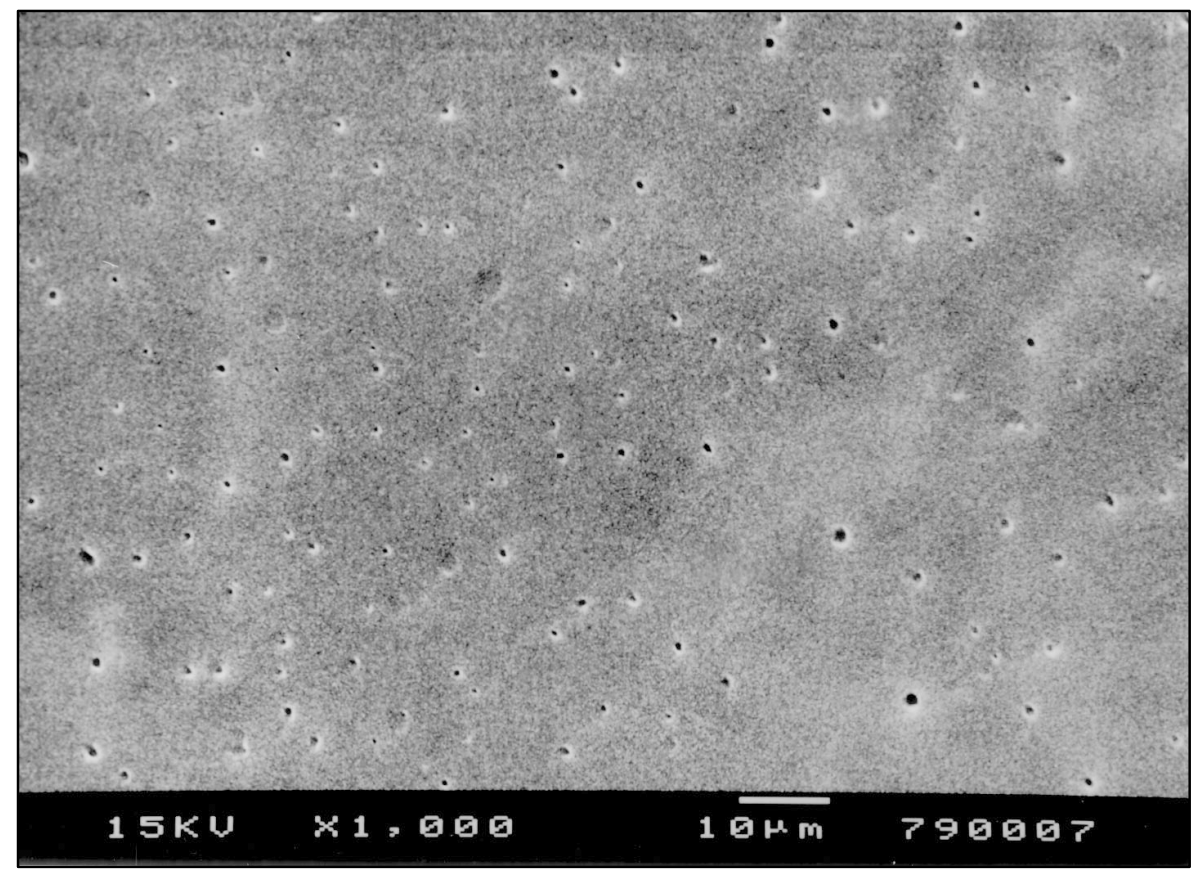

Figura 23B: Fotomicrografia eletrônica de varredura da réplica negativa da mesma superfície após 4 semanas sem tratamento. Os túbulos dentinários continuam presentes, mas com diâmetros similares. $O$ desconforto ao estímulo sonda foi classificado pelo paciente como moderado $(4,3)$ ao final do período. 


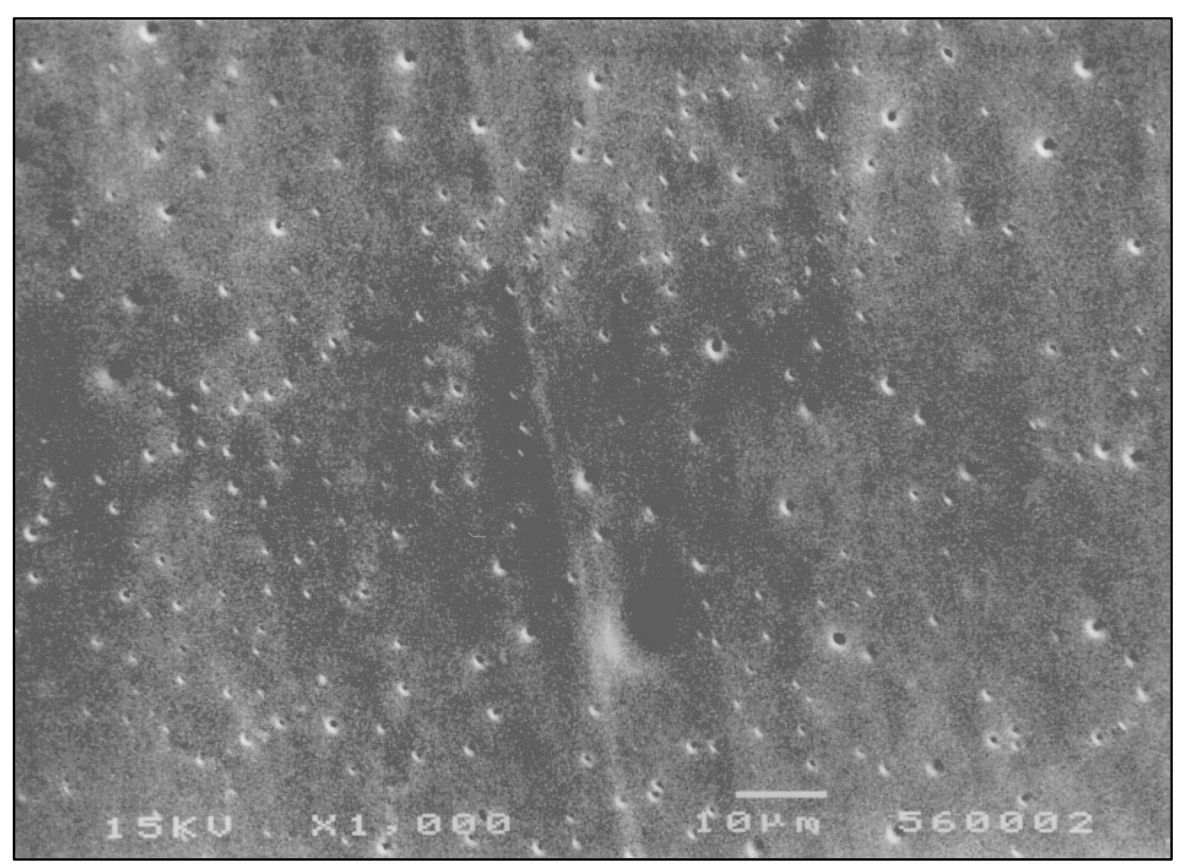

Figura 24A: Fotomicrografia eletrônica de varredura da réplica negativa de uma superfície dentinária com grau de sensibilidade classificado como intenso $(7,8)$ ao estímulo sonda e quase imperceptível $(1,7)$ ao estímulo jato de ar no baseline. Nota-se a grande quantidade de túbulos dentinários.

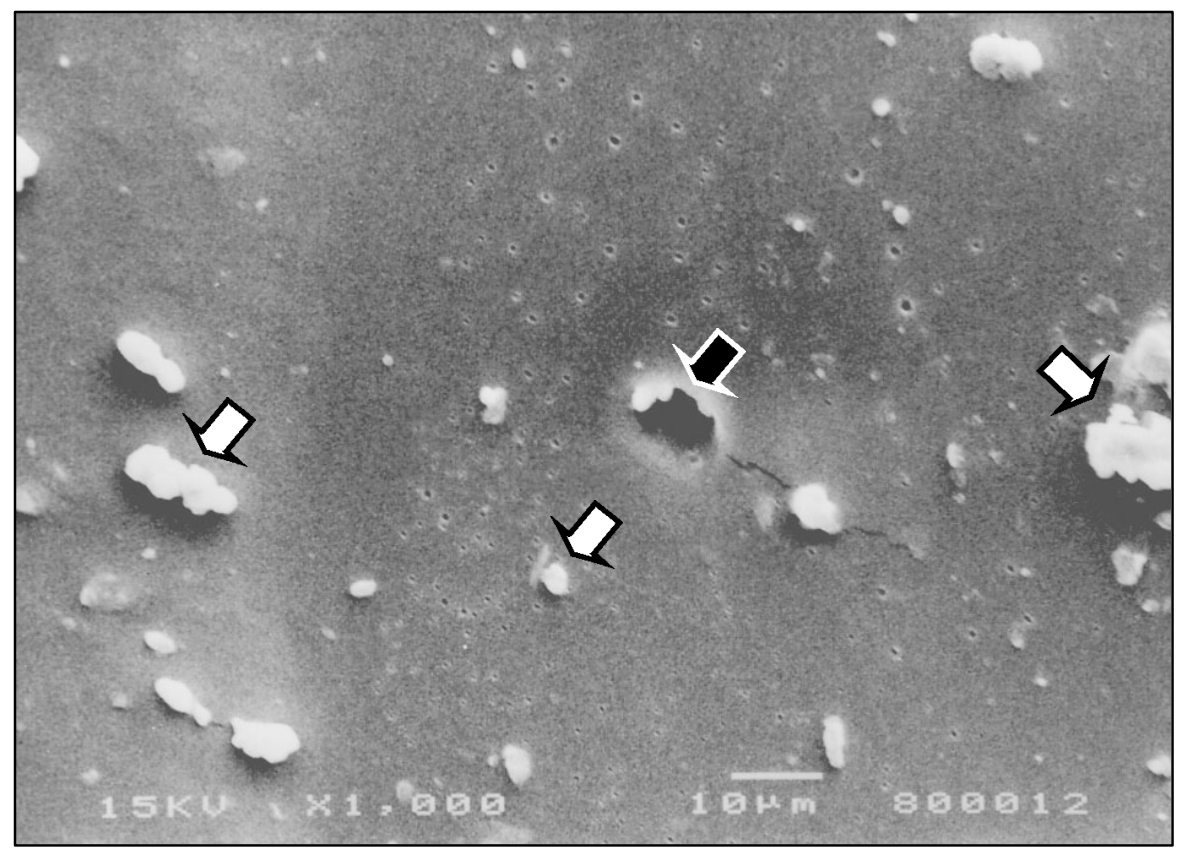

Figura 24B: Fotomicrografia eletrônica de varredura da réplica negativa, com diminuição considerável do grau de sensibilidade (3,7 para a sonda e 1,3 para 0 jato de ar), coincidente com a diminuição na quantidade e no diâmetro dos túbulos dentinários ao final de 4 semanas. As setas brancas indicam a presença de partículas, que podem ter contribuído para essa diminuição da sensibilidade. Essas partículas, quando não removidas durante o procedimento de moldagem, causaram defeito na superfície do molde, indicado pela seta preta. 


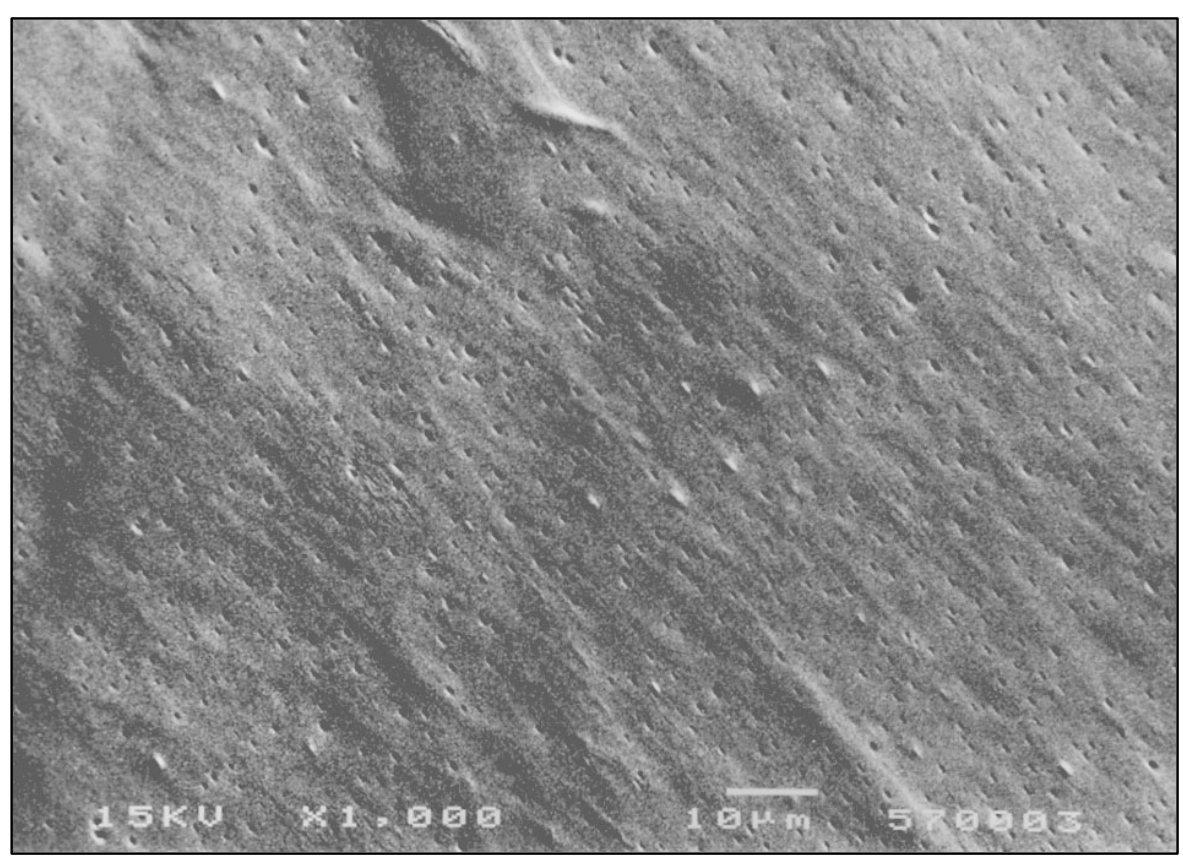

Figura 25A: Fotomicrografia eletrônica de varredura da réplica negativa de uma superfície dentinária com grande quantidade de túbulos dentinários, sendo relatado pelo paciente grau de sensibilidade intenso $(7,0)$ à sonda e leve $(3,4)$ ao jato de ar.

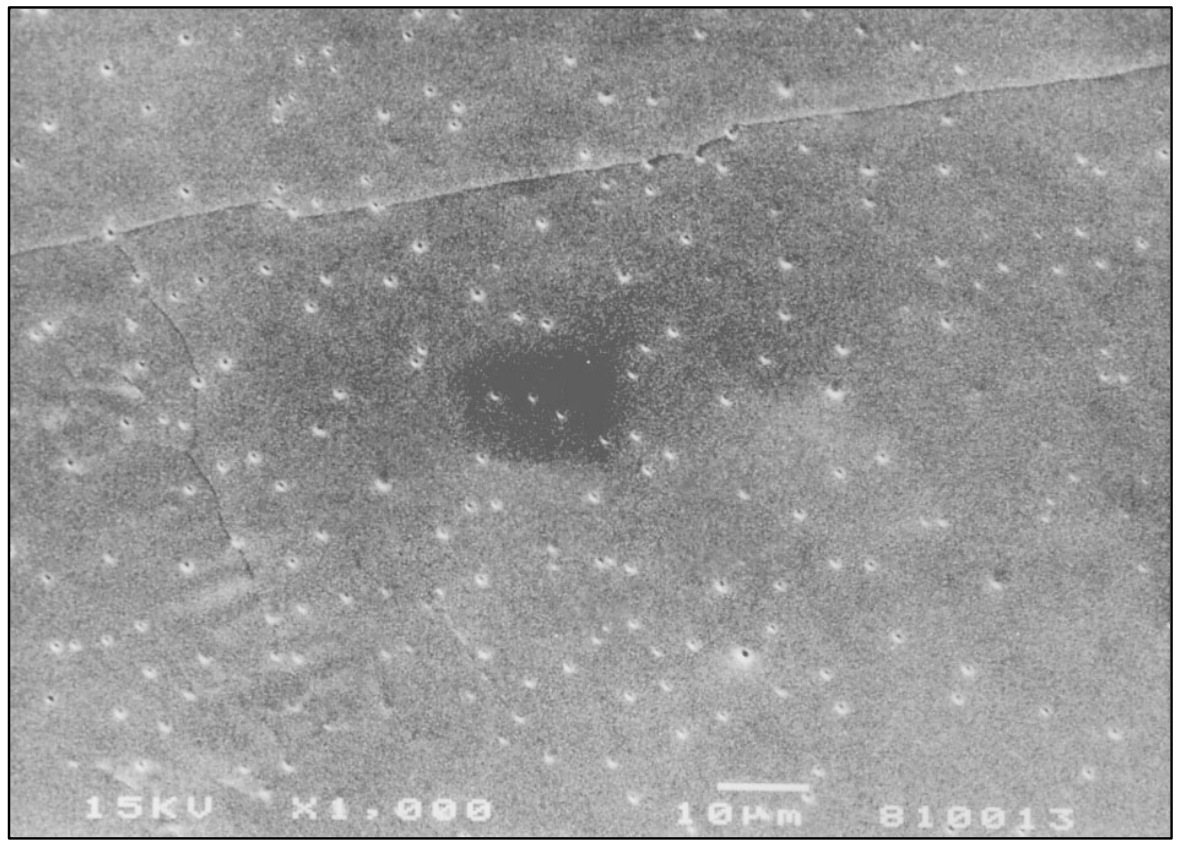

Figura 25B: Fotomicrografia eletrônica de varredura da réplica negativa da mesma superfície após o período de 4 semanas sem tratamento, quando 0 paciente relatou uma leve diminuição no desconforto para ambos os estímulos, grau de sensibilidade levemente forte $(5,8)$ à sonda e muito leve $(2,3)$ ao jato de ar, coincidente com a diminuição da quantidade dos túbulos dentinários. 


\section{DISCUSSÃO}

\subsection{DISCUSSÃO DA METODOLOGIA}

A aplicação de técnicas de réplica para o estudo das estruturas dentárias e sua interação com diferentes materiais restauradores data de 1940. Como se pode verificar no capítulo Revisão da Literatura, existe uma grande variedade de técnicas destinadas à obtenção de réplicas associadas à microscopia óptica ${ }^{112}$ de transmissão ${ }^{40}$ e de varredura ${ }^{87,88,12}$.

Além da diversidade de técnicas de réplica, a definição da terminologia foi bastante discutida. BARNES ${ }^{6}$, em 1978, sugeriu que, quando se obtém o molde da superfície a ser observada, tem-se uma cópia negativa dessa superfície, e o termo correto seria "primeira moldagem". O termo "réplica" deveria ser utilizado para amostras obtidas a partir da aplicação de um material fluido dentro desse primeiro molde, o qual seria observado no MEV.

A terminologia utilizada no presente trabalho baseou-se na nomenclatura comum à maioria dos trabalhos descritos. Assim sendo, quando se observa o molde da superfície diretamente no MEV, tem-se uma imagem negativa do substrato e, portanto, o termo utilizado é "réplica negativa". Quando o espécime é obtido a partir da aplicação de um material fluido nesse molde, resultando em uma cópia positiva do original, é denominado "réplica positiva". O termo "primeira moldagem" especifica o início do procedimento de obtenção das réplicas, quando uma moldagem prévia é realizada para promover a remoção de debris da superfície a ser avaliada.

A técnica de réplica associada à microscopia eletrônica de varredura tem diferentes aplicações na odontologia, tanto em estudos in vitro como in vivo. Dentre essas aplicações, podem ser destacados os estudos que utilizaram a técnica de réplica para observar a microestrutura dos tecidos duros 
dentários $^{40,112,28,17,105,80,57,70,110}$, a abrasividade de dentifrícios ${ }^{35}$, a superfície de restaurações ${ }^{50,122,49,29,77}$, a interação de diferentes materiais com as estruturas dentárias $^{121,128}$, a micromorfologia de tecidos moles e placa dental ${ }^{68,124,125,106,9,107}$, e o desenvolvimento de lesões cervicais não cariosas e as características de suas superfícies $^{25,8,4,14,127,11,9,10,78,13,62}$.

Poucas são as pesquisas envolvendo a aplicação da técnica de réplica no estudo das características da superfície da dentina, bem como da hiperestesia dentinária. Os primeiros autores a desenvolverem uma técnica de réplica para avaliação in vivo da superfície dentinária, sem que houvesse a necessidade de extração de dentes, foram ABSI; ADDY; $\mathrm{ADAMS}^{2}$, em 1989. Outros autores que aplicaram a técnica de réplica para a reprodução da dentina foram BEVENIUS; HULTENBY $^{8}$ e OYAMA; MATSUMOTO ${ }^{86}$, em 1991, RIMONDINI; BARONI; CARASSI $^{108}$, em 1995, enquanto que FERRARI et al. ${ }^{36}$, em 1999, aplicaram a técnica de réplica como meio auxiliar na avaliação de agentes dessensibilizantes. Os autores afirmam que as técnicas de réplica por eles utilizadas foram úteis no estudo da superfície dentinária sensível e não sensível, e que podem ser usadas para a avaliação clínica dos diferentes agentes anti-hiperestésicos. Além disso, deve-se observar que, na maioria dos trabalhos citados, seus autores realizaram previamente um estudo in vitro a fim de avaliar a técnica de réplica proposta, para depois aplicá-la em uma situação clínica sob condições ideais ${ }^{2}$. Da mesma forma, incluiu-se no presente trabalho um estudo in vitro com o objetivo de avaliar a eficácia da técnica de réplica utilizada, cuja metodologia é discutida a seguir.

\subsubsection{ESTUDO IN VITRO}

\section{Utilização de Discos de Dentina}

Os discos de dentina são amplamente empregados no estudo da morfologia 
dentinária e sua interação com diferentes materiais odontológicos. Importantes métodos de pesquisa têm sido aplicados no estudo da hiperestesia dentinária utilizando aparelhos para a medição da permeabilidade da dentina ${ }^{89}$ ou microscopia eletrônica de varredura a fim de avaliar a reatividade da dentina com os agentes anti-hiperestésicos ${ }^{92,41}$. Entretanto, as técnicas de preparo dos espécimes de dentes para microscopia podem introduzir artefatos que dificultam ou até mesmo inviabilizam a interpretação correta dos resultados ${ }^{8}$. Nos testes de reatividade da dentina com agentes dessensibilizantes, geralmente as seqüências laboratoriais para fixação e desidratação dos espécimes para a metalização resultam na dissolução dos depósitos químicos orgânicos ou inorgânicos que se acumulam sobre e no interior dos túbulos dentinários. A cópia do espécime utilizando materiais de moldagem e sua reprodução em resina epóxica têm sido empregadas por outros pesquisadores $^{111,2,108}$, com a finalidade de preservar os espécimes originais e reduzir, em alguma extensão, a produção de artefatos.

GILLAM; MORDAN; NEWMAN ${ }^{42}$, em um artigo publicado em 1997, revisaram os procedimentos de avaliação in vitro de agentes anti-hiperestésicos baseados na utilização de discos de dentina. Os autores concluíram que esse modelo, além de determinar as características da superfície e a redução da permeabilidade dentinária através da obliteração dos túbulos, representa um importante meio para avaliar-se o potencial de agentes dessensibilizantes. Ressaltaram, ainda, que a técnica de réplica proposta por ABSY; ADDY; $\mathrm{ADAMS}^{2}$, em 1989, pode reproduzir com detalhes a superfície da dentina, sendo útil a clínicos porque proporciona a observação direta, in vivo, do efeito de agentes terapêuticos que atuam por obliteração de túbulos no tratamento da hiperestesia dentinária.

Desse modo, na primeira fase do presente trabalho foram utilizados discos de dentina com $1 \mathrm{~mm}$ de espessura, os quais foram divididos em 4 quadrantes. Tal 
procedimento possibilitou não apenas a observação das diferentes condições estabelecidas em uma única amostra, como também reduziu o número de moldagens e de espécimes.

\section{Moldagem dos Discos de Dentina}

Para a moldagem dos discos de dentina utilizou-se uma silicona de adição (Aquasil ULV - Dentsply) que, tecnicamente, não forma subprodutos na sua polimerização, além de apresentar estabilidade dimensional que se mantém por longo período de tempo ${ }^{73}$. A utilização de silicona com consistência ultra leve, de baixa viscosidade, permitiu que esse material penetrasse na embocadura dos túbulos dentinários, formando tags e proporcionando uma moldagem detalhada da superfície, como pode ser observado nas Figuras 2A a 2D.

Entretanto, essas mesmas figuras mostraram que, quando a penetração da silicona foi profunda, as tensões geradas durante a remoção do molde proporcionaram deformações plásticas nas projeções mais finas, resultando no aspecto retorcido dos tags. Esse seria um dos inconvenientes do emprego da silicona de consistência ultra leve, e que pode ocorrer independentemente do tempo que se aguarda para a remoção do molde. No presente trabalho, os moldes foram deslocados do espécime 6 minutos após a presa do material de moldagem, a fim de simular a condição clínica.

\section{Obtenção das Réplicas Positivas}

Autores $50,5,28,25,54,122,124,2,8,4,125,14,106,127,11,9,10,107,78,27,33,13,49,80,62,128,29,36,77,57,70,110$ recomendam as resinas epóxicas como material adequado para obtenção de réplicas, e ressaltam as vantagens do estudo indireto dos espécimes. Nesse trabalho, as réplicas foram obtidas utilizando-se uma resina epóxica líquida de baixa 
viscosidade (Araldite GY 1109 BR, Ciba), modificada com diluente reativo, e formulada à base de Bisfenol A. Os endurecedores utilizados (HY 830 BR e HY 850 BR) também são líquidos e livres de solvente. O proporcionamento correto resultou em uma resina com viscosidade que permitiu a sua colocação no molde de tal modo que todos os detalhes obtidos pela silicona foram devidamente reproduzidos, evitando-se, dessa forma, a incorporação de bolhas.

Embora o Aquasil seja uma silicona de adição e, portanto, mais estável dimensional e quimicamente, optou-se pelo vazamento da resina epóxica depois de um período de 24 horas, apesar de o fabricante sugerir um mínimo de 12 horas antes da colocação do material que irá gerar o modelo. Assim, evitou-se a ocorrência de distorções, as quais poderiam comprometer sobremaneira a obtenção de réplicas perfeitas.

\subsubsection{ESTUDO IN VIVO}

Seleção dos Pacientes e dos Dentes

Uma importante etapa relacionada ao estudo clínico da hiperestesia dentinária é a seleção dos pacientes e dos dentes, a qual, segundo alguns autores $^{20,60,108,41,43,56}$, deve ser realizada com base em determinados critérios.

O primeiro critério de seleção do paciente foi que o mesmo apresentasse como queixa principal lesões cervicais não cariosas com sensibilidade em dentes caninos e pré-molares. Esses pacientes, em sua maioria, relataram que existia sensibilidade ao escovar os dentes, ao tomar água gelada e até mesmo ao falar, enfim, um desconforto presente em seu dia-a-dia. Dentre esses pacientes, foram selecionados aqueles que manifestaram interesse pelo tratamento e que concordaram com a metodologia a ser utilizada.

Foram consideradas, ainda, a saúde geral e bucal dos pacientes, os quais 
deveriam apresentar condições de saúde sistêmica dentro da normalidade para não influenciar os resultados. A condição bucal do paciente deveria permitir um diagnóstico correto da hiperestesia dentinária, sem a interferência de sinais e sintomas decorrentes de áreas próximas aos dentes incluídos na pesquisa.

Verificou-se o padrão de higiene bucal dos pacientes sem a utilização de qualquer tipo de evidenciador de placa bacteriana, com o propósito de evitar que o paciente, sabendo que seria examinado pelo cirurgião-dentista, pudesse ter melhorado sua escovação naquela ocasião, mascarando, assim, a realidade ${ }^{126}$. Desse modo, somente a visualização da ausência de cálculo e placa, da saúde gengival e do número de restaurações presentes foram os requisitos suficientes para a seleção dos pacientes.

O padrão de higienização é de fundamental importância, pois a presença de placa bacteriana visível, de cálculo ou de ambos poderia influenciar nos resultados do tratamento, bem como comprometer o procedimento de moldagem. Os pacientes com exposição da superfície radicular e controle de placa inadequado são mais predispostos à hiperestesia dentinária ${ }^{129,126}$. Segundo TROWBRIDGE; SILVER ${ }^{118}$, em 1990, a saliva contém íons cálcio e fosfato capazes de contribuir para a formação de depósitos minerais no interior dos túbulos dentinários. A presença de placa bacteriana poderia interferir nesse processo, já que as bactérias da placa, através da produção de ácido, são capazes de dissolver qualquer mineral precipitado, causando a abertura dos túbulos dentinários. Por outro lado, a presença de cálculo poderia causar a oclusão dos túbulos dentinários, diminuindo, assim, a condutibilidade hidráulica da dentina e alterando os padrões de hiperestesia.

Desde a primeira consulta como também durante o tratamento, nenhuma orientação quanto à higiene e fisioterapia bucal foi dada ao paciente, e tampouco nenhuma restrição quanto à ingestão de alimentos ou bebidas ácidas, a fim de que o 
paciente não modificasse seus hábitos, o que poderia influenciar diretamente os resultados da pesquisa.

A hiperestesia dentinária pode ocorrer em qualquer dente; porém, a maioria dos estudos de incidência e prevalência, como os de ORCHARDSON; COLLINS ${ }^{83}$, em 1987, COLLAERT; FISCHER ${ }^{22}$, em 1991, aponta caninos e pré-molares como os mais comumente afetados pela hiperestesia dentinária, quase sempre na face vestibular. Com base nesses estudos, na presente avaliação selecionaram-se dentes caninos e pré-molares, nos quais as lesões cervicais não cariosas são mais freqüentemente encontradas.

Ainda com referência aos critérios de seleção de pacientes, estudos clínicos como os de KAUFMAN; KLEINBERG ${ }^{60}$, em 1994, RIMONDINI; BARONI; CARRASSI ${ }^{108}$, em 1995 e HOLLAND et al. ${ }^{56}$, em 1997, determinaram outros requisitos básicos como a não utilização anterior de agentes anti-hiperestésicos, a presença de dentina exposta causada por abrasão, erosão ou abfração e/ou recessão gengival, a ausência de cáries, restaurações e de esmalte trincado. Assim, os dentes selecionados para a realização do presente estudo não apresentavam cáries, trincas ou fraturas, restaurações extensas ou insatisfatórias, prótese ou aparelhos de contenção e forças oclusais anormais incidindo sobre os mesmos. Após a seleção dos dentes, foram realizados anamnese, exames clínico e, quando necessário, o radiográfico, para compor o diagnóstico diferencial da dor, já que existem muitas situações clínicas cujos sintomas podem ser confundidos com hiperestesia dentinária. Entre estas, incluem-se síndrome do dente trincado, restaurações fraturadas, cárie dental, sensibilidade pós-operatória, hipoplasia de esmalte, dentes em hiperfunção e, ainda, a abertura congênita da junção cementoesmalte 31,118 .

Dentes com problemas periodontais, como bolsas e mobilidade, e trauma 
oclusal patológico foram descartados, pois poderia ocorrer a necessidade de cirurgia periodontal ou mesmo exodontia no decorrer do tratamento ${ }^{20}$.

A etiologia da lesão cervical não cariosa não foi considerada, podendo os dentes apresentarem erosão, abrasão ou abfração desde que apresentassem grau de sensibilidade mínimo correspondente a $3 \mathrm{~cm}$ ao estímulo sonda ou jato de ar, de acordo com a Escala Visual Analógica (EVA), para serem considerados hiperestésicos. Deve-se ressaltar que, embora a uniformidade da amostra quanto ao grau de sensibilidade seja de extrema importância em estudos da hiperestesia, tal aspecto não foi considerado, pois o objetivo do presente trabalho não foi avaliar a eficácia de um agente anti-hiperestésico, mas sim tentar correlacionar as características superficiais da dentina com o grau de sensibilidade relatado pelo paciente nos diferentes momentos.

\section{Agente Anti-hiperestésico Utilizado}

Dentre as formas de tratamento da hiperestesia dentinária, podem ser citadas aquelas que têm influência na ação neural ou as que promovem a obliteração dos túbulos dentinários. Segundo a Teoria da Hidrodinâmica, introduzida por BRÄNNSTRÖM ${ }^{15}$, em 1966, um estímulo aplicado na superfície da dentina exposta causa um rápido movimento do fluido no interior dos túbulos dentinários, ativando as terminações nervosas presentes na interface dentinopulpar. Assim, o objetivo principal do tratamento seria a obliteração ou selamento dos túbulos dentinários ${ }^{30,129}$.

O oxalato de potássio apresenta um grande potencial para o tratamento da hiperestesia dentinária. De acordo com PASHLEY et al. ${ }^{96}$, em 1986 e MUZZIN; JOHNSON ${ }^{82}$, em 1989, esse agente atua na obliteração dos túbulos dentinários por meio da precipitação de partículas (cristais) insolúveis e também por ação neural. 0 selamento dos túbulos pode ser conseguido com a aplicação tópica de oxalatos, que 
formam precipitados insolúveis na embocadura e no interior dos túbulos dentinários, reduzindo o fluxo do fluido e controlando a sensibilidade da dentina exposta ${ }^{47}$. Esse tipo de tratamento é relatado por muitos autores, que utilizaram o oxalato de potássio em diferentes concentrações. Os sais de potássio apresentam-se eficazes no tratamento da hiperestesia dentinária, pois agem por despolarização das membranas das fibras nervosas, por bloqueio da passagem do estímulo, e não por obstrução dos túbulos dentinários pela deposição de cristais ou pela diminuição a condutibilidade hidráulica da dentina ${ }^{98}$.

De acordo com as recomendações de GROSMANN ${ }^{48}$, em 1935, para a escolha do agente anti-hiperestésico ideal, o oxalato de potássio atende aos requisitos de não ser irritante à polpa, ser de fácil aplicação, não manchar ou descolorir o dente e ter baixo custo. A ação rápida e o efeito duradouro podem ser confirmados através de estudos laboratoriais ${ }^{47,95,92}$ e clínicos $^{82,55,43,126,74.75}$, nos quais os autores observaram que o oxalato de potássio diminuiu consideravelmente a permeabilidade da dentina e, consequentemente, a hiperestesia dentinária.

\section{Estímulos}

A referência à literatura pertinente, em particular aos estudos clínicos que abordam o tratamento da hiperestesia dentinária, oferece uma variedade de metodologias empregadas, principalmente quanto ao tipo de estímulo utilizado e à mensuração da resposta. Os estímulos que podem ser empregados para avaliar a hiperestesia dentinária são classificados em tácteis, térmicos, evaporativos, elétricos e químico-osmóticos.

No presente estudo, a escolha dos estímulos sonda exploradora e jato de ar foi feita com base na metodologia aplicada em avaliações clínicas e, particularmente, nas recomendações de HOLLAND et al. $^{56}$, em 1997, que sugeriram o uso desses 
dois estímulos hidrodinâmicos por serem controláveis. Considerou-se, ainda, que os pacientes relataram dor ao escovar os dentes, ao ingerirem alimentos frios e até mesmo ao falar, ou seja, diante de estímulos tácteis e térmico-evaporativos. Um outro fator de escolha desses estímulos deveu-se ao fato de o clínico utilizá-los freqüentemente em seu consultório.

Segundo PASHLEY ${ }^{89}$, em 1990, a sonda exploradora constitui um meio simples e rápido para o diagnóstico da hiperestesia dentinária. A padronização da avaliação em um ponto específico da lesão onde ocorre a hiperestesia é praticamente inviável e, porisso, esse estímulo táctil foi utilizado em toda a extensão da lesão até que o paciente relatasse dor semelhante à que o fez procurar por tratamento, como nas avaliações clínicas realizadas por JENSEN; DOERING ${ }^{59}$, em 1987; ORCHARDSON; COLLINS ${ }^{83}$, em 1987; OYAMA; MATSUMOTO ${ }^{86}$, em 1991, HOLBOROW ${ }^{55}$, em 1994; PEARCE; ADDY; NEWCOMBE ${ }^{99}$, em 1994; SILVERMAN; GINGOLD; CURRO ${ }^{116}$, em 1994; PEREIRA et al. ${ }^{102}$, em 1994; ESTRELA et al. ${ }^{34}$, em 1996, WEST et al. ${ }^{126}$, em 1997 e MARTINELLI, em $1999^{74}$.

Sabe-se que a compressão da dentina causa o deslocamento do fluido no interior dos túbulos dentinários ${ }^{89}$ e, por conseguinte, é importante a padronização da pressão utilizada, pois a alteração da mesma pode gerar respostas não condizentes com a realidade. Na presente avaliação clínica, a sonda exploradora foi aplicada contra a dentina com uma pressão semelhante à utilizada no ato da escovação. Cabe salientar que esse procedimento foi realizado sempre pelo mesmo operador, a fim de obter uma padronização do estímulo, como recomendado por HERNANDEZ et al. ${ }^{53}$, em 1972.

O estímulo evaporativo é assim denominado por causar, além da movimentação do fluido dentinário, a sua evaporação, ativando as terminações nervosas ${ }^{89}$. Os estudos clínicos relatam uma diversidade de maneiras de utilização 
do jato de ar e, segundo PASHLEY ${ }^{89}$, em 1990, não existe uma padronização para esse estímulo, podendo a sua aplicação variar conforme o tempo, temperatura e distância do dente. JENSEN; DOERING ${ }^{59}$ e ORCHARDSON; COLLINS ${ }^{83}$, em 1987, OYAMA; MATSUMOTO ${ }^{86}$, em 1991, PEREIRA et al. ${ }^{102}$, em 1994 e ESTRELA et al. ${ }^{34}$, em 1996 utilizaram o jato de ar, embora não tivessem especificado a temperatura e o tempo de aplicação desse estímulo. PEARCE; ADDY; NEWCOMBE ${ }^{99}$, em 1994, utilizaram o jato de ar por 3 segundos, a $3 \mathrm{~cm}$ da dentina, mas não relataram a qual temperatura. SILVERMAN; GINGOLD; CURRO ${ }^{116}$, em 1994 e GILLAM et al. ${ }^{44}$, em 1996 utilizaram o jato de ar por 1 segundo à temperatura de 19 a $21^{\circ} \mathrm{C} \pm 3^{\circ} \mathrm{C}$. Em um estudo seguinte, GILLAM et al. ${ }^{43}$, em 1997, utilizaram novamente $o$ jato de ar com temperatura entre $19^{\circ}$ e $24^{\circ} \mathrm{C}$, posicionado perpendicularmente a $1 \mathrm{~cm}$ de distância do dente. Na presente pesquisa, o jato de ar foi aplicado em temperatura ambiente por 1 segundo, a $1 \mathrm{~cm}$ de distância do dente. Essa temperatura é importante pois a baixa temperatura poderia atuar como estímulo térmico (frio), o que poderia modificar a resposta.

Os estímulos devem ser aplicados de maneira que a resposta a um estímulo não interfira na resposta ao outro. Autores como KAUFMAN; KLEINBERG ${ }^{60}, 1994$, GILLAM et al. ${ }^{43}, 1997$, e GILLAM $^{41}$, 1997 recomendam, primeiramente, o uso do estímulo que causa menor desconforto e, depois de um intervalo, a aplicação do outro que traz maior desconforto. No presente estudo, a fim de evitar a interferência entre os estímulos, utilizou-se inicialmente a sonda exploradora e, após 5 minutos, fez-se a mensuração da dor com o estímulo jato de ar.

\section{Aplicação do Agente Anti-hiperestésico}

O agente anti-hiperestésico foi aplicado seguindo-se as recomendações do fabricante. A profilaxia com pedra-pomes e água não foi necessária porque nenhum 
paciente apresentou acúmulos grosseiros de placa ou cálculo. Desse modo, seguiuse a recomendação do fabricante do Oxa-Gel ${ }^{\circledR}$, que salienta a eficácia desse produto em tais circunstâncias. Essa propriedade do Oxa-Gel ${ }^{\circledR}$ constitui uma vantagem importante do produto, já que torna o procedimento de aplicação mais confortável para o paciente, e não promove o risco de exacerbação da hiperestesia dentinária previamente à aplicação dos agentes e à mensuração da resposta hiperestésica. Além disso, existe a possibilidade de que partículas minerais provenientes do meio bucal armazenadas na superfície dentinária sirvam de substrato para a reação com o oxalato, acentuando o seu potencial para a precipitação de cristais sobre a dentina exposta.

Após o isolamento relativo, a superfície dentinária foi umedecida, e o excesso de água removido com papel absorvente para, então, aplicar-se, passivamente, o agente anti-hiperestésico. Esse procedimento foi realizado com base em um estudo in vitro realizado por PEREIRA; SEGALA; CARVALHO ${ }^{101}$, em 1996, no qual a utilização do oxalato de potássio mostrou os melhores resultados quando a dentina foi mantida úmida após a aplicação do ácido.

\section{Mensuração da Resposta}

Os estudos de avaliação clínica de hiperestesia dentinária baseiam-se no relato do paciente e na mensuração do grau de sensibilidade, ou seja, em respostas subjetivas.

Pode-se verificar, na Revisão da Literatura, que os métodos de avaliação do grau de sensibilidade estão fundamentados em escalas e questionários específicos, através dos quais o paciente "quantifica" a sua dor. As escalas mais comumente utilizadas são a Escala Visual Analógica (EVA) e a Escala de Medida Verbal (EMV). Na presente avaliação clínica, optou-se pela utilização da EVA, que consiste de uma 
linha horizontal com $10 \mathrm{~cm}$ de comprimento, e cujas extremidades representam os limites da dor, ou seja, ausência de desconforto (0) e desconforto severo (10). O paciente avalia, então, a intensidade de sua dor no momento da aplicação de cada estímulo. Essa escala possibilita uma aproximação da sensação de dor por meio das opções oferecidas, ainda que sutilmente diferentes, como visto na Figura 2.1, no capítulo Revisão da Literatura.

Em um estudo clínico realizado em 1988, HANSSON; BYE; SMITH ${ }^{52}$ compararam três diferentes escalas (Escala Visual Analógica, Escala de Medida Verbal e Escala de Medida Numérica) a um questionário específico (McGill) entre si, e concluíram que existe uma forte correlação entre elas, o que não ocorreu com relação ao questionário.

\section{Limpeza da Superfície Dentinária}

A limpeza da superfície dentinária antes do procedimento de moldagem é necessária e de fundamental importância. Embora a matéria orgânica sobre a dentina não influencie o movimento do fluido dentinário e, portanto, a resposta a estímulos, pode dificultar a penetração do material de moldagem e, assim, comprometer a cópia dos detalhes superficiais da dentina ${ }^{2}$. Ao utilizarem a técnica de réplica in vivo, os autores apresentam diferentes opções para a limpeza da superfície a ser moldada, desde o simples uso de bastonetes de algodão embebidos em água e/ou jato de ar, até o condicionamento da superfície com ácidos em diversas concentrações.

Em um estudo sobre tecidos moles, PAMEIJER; STALLARD ${ }^{88}$, em 1972, realizaram a limpeza da superfície a ser moldada somente com água e jato de ar e sob isolamento relativo, a fim de evitar a contaminação com saliva. O mesmo procedimento foi aplicado por outros autores ${ }^{68,124,4,}$, também na avaliação de tecidos 
moles e de depósitos sobre os tecidos dentários in vivo, e, ainda, no estudo de tecidos dentários duros ${ }^{10,78,128}$. Apenas a utilização do jato de ar para a secagem da área a ser moldada foi o procedimento adotado por BRADY; WOODY ${ }^{13}$, em 1997, para avaliar a incidência e as características de lesões cervicais.

O hipoclorito de sódio em diferentes concentrações, associado ou não a outros agentes de limpeza, seguido da lavagem com água destilada ou com seringa tríplice e secagem com jato de ar vêm sendo amplamente empregados na limpeza das superfícies a serem moldadas.

LAMBRECHTS; VANHERLE; DAVIDSON ${ }^{69}$, em 1981, propuseram que, para a remoção de placa, película adquirida e remanescentes orgânicos, a superfície a ser moldada deveria ser limpa com bastonetes de algodão embebidos em hipoclorito de sódio e água oxigenada em concentrações não especificadas, sendo posteriormente lavada com água e secada com jato de ar. Na pesquisa realizada por VOSSEN et al. ${ }^{122}$, em 1985, foram utilizadas três diferentes soluções para a limpeza da superfície, entre as quais o hipoclorito de sódio a $3 \%$ que, aplicado antes da moldagem, foi considerada a solução mais eficiente. WAKABAYASHI ${ }^{123}$, em 1988, aplicou hipoclorito de sódio a 10\% com a finalidade de remover tecidos pulpares e pré-dentina de dentes extraídos, os quais permaneceram submersos por 72 horas antes da obtenção das réplicas. Em 1989, ABSY; ADDY; $\mathrm{ADAMS}^{2}$, em um estudo clássico de réplicas de dentina, utilizaram o hipoclorito de sódio a 1\%, seguido da lavagem com água destilada e secagem com jato de ar, sob isolamento absoluto. OYAMA; MATSUMOTO ${ }^{86}$, em 1991, usaram esponjas embebidas em álcool a 70\% e hipoclorito de sódio a 3\%, seguindo-se lavagem com água destilada e secagem com jato de ar. RIMONDINI; BARONI; CARASSI ${ }^{108}$, em 1995, em outro estudo clássico da superfície dentinária através de réplicas, utilizaram solução de hipoclorito de sódio a 5\% na primeira etapa do trabalho. 
No estudo in vitro, o condicionamento com ácido cítrico a 6\%, como sugerido por PASHLEY; KALATHOOR; BURNHAM ${ }^{94}$, em 1986, GILLAM; MORDAN; NEWMAN ${ }^{42}$, em 1997, GILLAM et al. ${ }^{45}$, em 1999 e PASHLEY et al. ${ }^{97}$, 2001, permitiu a remoção total da smear layer, o que possibilitou a caracterização da dentina hiperestésica pela exposição dos túbulos dentinários, facilitando, assim, a penetração do material de moldagem no interior dos mesmos.

O condicionamento da superfície de dentina exposta com ácido fosfórico a $37 \%$ por 10 segundos antes da aplicação do oxalato de potássio foi empregado in vivo por HIRVONEN; NÄRHI; HAKUMÄKI ${ }^{54}$, em 1984, e também por RIMONDINI; BARONI; CARASSI ${ }^{108}$, em 1995, os quais utilizaram o mesmo ácido por 10 segundos para eliminar barreiras de minerais e expor os túbulos dentinários antes da realização das moldagens. Deve-se ressaltar que o condicionamento prévio com ácido é indicado em estudos laboratoriais de permeabilidade dentinária, segundo os quais a remoção da smear layer é necessária para simular a máxima permeabilidade $^{79}$. Clinicamente, tal procedimento poderia contribuir para a ampliação do diâmetro dos túbulos dentinários e dissolução de minerais necessários para a reação com o agente dessensibilizante, aumentando, consequentemente, o grau de hiperestesia dentinária.

Uma outra opção para a limpeza da superfície foi sugerida por PAMEIJER; STALLARD $^{88}$, em 1972. Esses autores utilizaram uma fita de celoidina embebida em acetona para obtenção de réplicas negativas da superfície dentinária, realizando a denominada "primeira moldagem", com a finalidade de remover partículas. Essa fita era, então, descartada e o procedimento repetido, obtendo-se, assim, o molde final.

Em 1979, BARNES ${ }^{7}$ já ressaltava que, independentemente da técnica de réplica empregada, a superfície deve ser limpa antes mesmo de fazer-se a moldagem preliminar (ou "primeira moldagem"), a qual removeria as impurezas mais 
grosseiras da superfície.

No presente estudo, com a finalidade de promover a limpeza da superfície, associaram-se dois procedimentos: primeiro, sob isolamento relativo com afastador labial, roletes de algodão e sugador, aplicou-se ativamente um bastonete de algodão embebido em hipoclorito de sódio a $1 \%$, sendo a superfície lavada com água destilada e secada com jato de ar, como proposto por ABSY; ADDY; ADAMS $^{2}$, em 1989. É preciso ressaltar que, de acordo com esses autores, quando se utiliza a técnica de réplica, principalmente no estudo de hiperestesia dentinária, é essencial a aplicação de anestesia local, pois a área deve ser limpa e seca o suficiente para assegurar que a pressão do fluido dentinário não interfira no procedimento de moldagem. Essa conduta, entretanto, não foi praticada no presente estudo, pois os pacientes, em sua maioria, apresentavam dentes hiperestésicos em diferentes quadrantes.

No segundo procedimento utilizado para a limpeza da superfície, fez-se uma moldagem prévia da superfície (ou "primeira moldagem") a fim de remover as impurezas e debris, a qual foi descartada. Igual procedimento foi adotado em pesquisas mais recentes ${ }^{8,9,128}$. Esse tipo de preparo da superfície para a moldagem, segundo ABSI; ADDY; ADAMS $^{1}$, em 1987, não afeta as características da dentina, embora a simples limpeza da superfície com hipoclorito seja considerado por outros autores $^{108}$ um procedimento mais rápido e menos irritante, pois a moldagem prévia consome muito tempo em uma situação clínica.

\section{Moldagem da Superfície Dentinária}

As técnicas de réplica relatadas na literatura utilizaram desde polietireno ${ }^{40}$, películas de celoidina embebidas em acetona ${ }^{87,112}$, até materiais de moldagem elastoméricos $^{50,49,105}$, como as siliconas de condensação ${ }^{35,5,28,67,25,54,122,2,4,14108,78}$ e as 
siliconas de adição $69,68,124,8,86125,106,127,11,9,10,107,27,33,121,17,80,128,29,36,77,57,70,110$.

Um dos objetivos do presente trabalho foi avaliar a capacidade de reprodução da superfície dentinária, por meio da técnica de réplica, utilizando-se uma silicona de adição de consistência ultra-leve e uma resina epóxica.

Diversos materiais de moldagem são usados para obter-se uma cópia fiel dos tecidos orais e, a partir de suas propriedades físicas, são classificados em materiais rígidos ou elásticos. A procura de materiais que recuperassem sua forma e dimensão quando removidos de áreas retentivas levou ao desenvolvimento dos materiais elásticos, entre os quais incluem-se os hidrocolóides reversíveis e irreversíveis (alginatos). Entretanto, sua incapacidade de reproduzir detalhes fez com que esses materiais fossem descartados para moldagens mais sensíveis ${ }^{73}$.

As mercaptanas (ou polisulfetos) foram os primeiros polímeros elásticos lançados no mercado, e são constituídos de duas pastas (base e catalizadora) que, quando misturadas, tornam a massa plástica mais espessa até a formação de uma borracha sólida. Durante e após a presa da mercaptana, observa-se uma contração que continua gradualmente com o decorrer do tempo. A fim de obter moldes mais fiéis, os modelos devem ser vazados o quanto antes, embora esse tempo não seja tão crítico quanto o dos hidrocolóides ${ }^{73}$.

Os elastômeros mais utilizados atualmente na clínica odontológica são as siliconas, classificadas em siliconas de adição e siliconas de condensação conforme o tipo de reação de polimerização ${ }^{73}$. As siliconas de adição, ou vinil polisiloxanos ou polivinil siloxanos, foram, inicialmente, introduzidas no anos 70 . Desde então, esses materiais vêm ganhando grande aceitação devido às suas aplicações em diferentes campos da odontologia ${ }^{73,74}$.

As siliconas de adição, independentemente da sua viscosidade ou consistência, são comercializadas em forma de duas pastas (base e catalizadora), 
as quais podem ser misturadas manualmente ou dispensadas em seringas, sempre em quantidades iguais ${ }^{73}$.

Os polivinil siloxanos são modificações das siliconas de condensação, apresentando diferenças quanto ao tipo de reação de polimerização. Como possuem peso molecular relativamente baixo, ao contrário das siliconas de condensação, não produzem um subproduto volátil durante a polimerização, o que os coloca em uma categoria separada dos demais materiais de moldagem ${ }^{73,74}$. Essa característica determina uma estabilidade dimensional que se mantém estável por longo período de tempo ${ }^{74}$.

Outra propriedade favorável da silicona de adição utilizada é a sua natureza tixotrópica, ou seja, sua capacidade de permanecer sobre o local onde foi aplicada sem, no entanto, escorrer. Essa característica determinou o modo de aplicação do material, pois o Aquasil, em consistência ultra-leve, foi levado e acomodado cuidadosamente com uma espátula metálica número 24 sobre a superfície de dentina exposta ${ }^{50,4,57}$.

Por outro lado, as moldeiras individuais, confeccionadas em acrílico ou cobre, são indicadas em técnicas de moldagem com materiais de consistências diferentes (pesada e leve), conforme sugerido em alguns estudos $5,7,69,8,68,54,122,11,9,105$.

A silicona de adição é considerada o material de moldagem mais fiel para reprodução de detalhes. Com exceção do material pesado, as demais consistências permitem a visualização de detalhes da ordem de 1 a $2 \mu \mathrm{m}$, ou menor que $20 \mu \mathrm{m}^{74}$. Em 1991, AKPATA; WINTER ${ }^{4}$ ressaltaram que, para favorecer a cópia de finos detalhes, o material de moldagem deve apresentar consistência leve, e fluir no interior da camada superficial de dentina.

Conforme o fabricante do Aquasil ULV (Dentsply), esse material é capaz de penetrar no interior dos túbulos dentinários úmidos, e possui resistência o suficiente 
para ser removido sem que os micro tags (de 3 a $5 \mu \mathrm{m}$ ) se rasguem, o que comprova sua alta capacidade de reprodução de detalhes. Ainda segundo o fabricante, essa capacidade é conseqüência de um composto básico do produto, o siloxano hidrófilo quadrifuncional (QHS), desenvolvido pela Dentsply. As propriedades hidrófilas inerentes a esse material resultam em uma capacidade única de molhamento da superfície dentária. Entretanto, conforme DERRIEN; LE MENN²7, em 1995, e MANDIKOS $^{73}$, em 1998, ainda não existem evidências científicas que comprovem que a silicona de adição seja hidrófila o bastante para, quando inserida em sulcos úmidos, resultar em um molde perfeito dessa região. Essa característica é de extrema importância, visto que a dentina é um substrato úmido e, no caso de lesões cervicais não cariosas, encontra-se próxima do sulco gengival.

\section{Réplicas de Resina Epóxica}

Quando se tem por objetivo observar o molde diretamente no MEV, a principal consideração é verificar a reprodução dos mínimos detalhes da superfície. Se, entretanto, réplicas positivas serão produzidas, é necessário que se considere a compatibilidade entre o material de moldagem e a resina ${ }^{27}$. De acordo com o fabricante, o Aquasil é compatível com diferentes materiais usados para a confecção de modelos, inclusive resinas epóxicas, e pode, ainda, ser metalizado.

$\mathrm{Na}$ grande maioria dos trabalhos citados na Revisão da Literatura, a resina epóxica foi utilizada para obtenção de réplicas positivas, mas são poucos estudos que salientaram as vantagens ${ }^{87,67,4,121,17,105}$ e as desvantagens ${ }^{50}$ em observar-se o molde metalizado, ou "réplica negativa", diretamente no MEV.

As considerações a respeito da utilização de réplicas negativas no presente trabalho são discutidas a seguir. 


\subsection{DISCUSSÃO DOS RESULTADOS}

\subsubsection{ESTUDO IN VITRO}

Nesse estudo, buscou-se uma avaliação seqüencial comparativa entre as superfícies dentinárias tratadas in vitro com o agente anti-hiperestésico à base de oxalato de potássio, contrapondo as características da superfície do discos de dentina com aquelas dos moldes e das réplicas correspondentes. Essa estratégia permitiu observar não apenas a interação do agente com a dentina, mas também o padrão das moldagens e sua possível interferência com as réplicas positivas.

A comparação entre discos de dentina e réplicas, no que diz respeito às superfícies com smear layer e condicionamento com ácido cítrico, confirma o grau de reprodutibilidade das réplicas, como visto nas Figuras $1 \mathrm{~A}, 1 \mathrm{~B}, 3 \mathrm{~A}$ e $3 \mathrm{~B}$. Os detalhes das superfícies, típicos da smear layer, foram copiados pela silicona e reproduzidos com fidelidade pela resina epóxica de baixa viscosidade. Entretanto, quando os túbulos dentinários foram expostos e ampliados pelo condicionamento ácido, a grande capacidade de penetração da silicona resultou na formação de tags excessivamente longos que, no momento da remoção do molde, sofreram deformação plástica, tornando-se retorcidos e colapsados. A réplica resultante incorporou os defeitos da superfície como artefatos próprios da moldagem. Quanto mais amplos e desobstruídos estiverem os túbulos dentinários, mais profundamente o material de moldagem penetra, e mais facilmente os artefatos serão reproduzidos. Ainda assim, é perfeitamente possível a identificação de uma superfície dentinária com aspecto típico de dentina condicionada.

Outros autores também constataram a eficácia da réplica ao reproduzirem túbulos dentinários com diâmetro entre 1 e $2 \mu \mathrm{m}$ e detalhes de 0,5mm empregando moldagens com silicona ${ }^{2}$. 
Nos espécimes tratados com o agente anti-hiperestésico Oxa-Gel ${ }^{\circledR}$, pode-se considerar que as réplicas reproduziram parte das características da superfície tratada. Esse agente tem como característica de reação a deposição de cristais na embocadura e no interior dos túbulos dentinários ${ }^{92}$, a qual foi claramente observada na Figura 1C.

Como o condicionamento ácido para remover a smear layer consome cálcio da superfície da dentina, o oxalato de potássio reage com o remanescente mineral no interior dos túbulos dentinários, obstruindo sua embocadura a partir de uma distância de $5 \mu \mathrm{m}$ da superfície ${ }^{42}$. Essa condição faz com que a moldagem (Figura 2C) seja menos penetrante do que no espécime condicionado e não tratado (Figura 2B). Os tags de silicona são mais curtos e permanecem eretos em sua maioria, permitindo uma réplica com menos artefatos (Figura $3 \mathrm{C}$ ). Nessa mesma figura, pode-se notar o volume dos depósitos cristalinos no interior dos túbulos dentinários (setas).

O desafio subsequente com ácido cítrico dissolveu parcialmente os cristais, desobstruiu parte dos túbulos (Figura 1D), e permitiu maior difusão da silicona intratubularmente (Figura 2D). Os cristais remanescentes dão um caráter mais retentivo aos túbulos, provocando o rompimento de certo número de tags de silicona no interior dos mesmos (Figura 3D - setas). A exata comparação das mesmas áreas entre disco, molde e réplica, entretanto, não foi possível nessa etapa do trabalho por não ter sido encontrado um método para localizá-las com precisão microscópica necessária. Procurou-se, porém, documentar sempre as mesmas regiões de cada quadrante que guardassem, de modo geral, as mesmas características.

Nessas condições, pode-se considerar que as réplicas são recursos importantes para monitorar as alterações da morfologia superficial da dentina durante as pesquisas clínicas sobre hiperestesia dentinária. O domínio da técnica de 
moldagem e da obtenção de réplicas pode permitir, inclusive, o registro das diferentes reações dos agentes anti-hiperestésicos com o substrato dentinário.

O presente trabalho demonstra que detalhes importantes da superfície dentinária tratada e não tratada podem ser distinguidos ao MEV em uma ampliação relativamente pequena de $1000 \mathrm{X}$.

Mesmo diante das considerações referentes à sensibilidade da técnica, as imagens obtidas através da replicação dos discos dentinários in vitro comprovaram que esse procedimento não invasivo pode ser viável para aplicação clínica em substituição à biópsia da dentina ${ }^{133,134}$, ou mesmo à extração de dentes para a observação direta de sua superfície.

\subsubsection{ESTUDO IN VIVO}

O presente trabalho teve como objetivos analisar, in vivo, através da técnica de réplica, as características superficiais da dentina hiperestésica, o efeito do oxalato de potássio $\left(O x a-G e l^{\circledR}\right)$ sobre a essa superfície, as suas possíveis modificações da em um determinado período de tempo sem qualquer tratamento, e, finalmente, correlacionar, in vivo, as características superficiais da dentina quanto à presença de túbulos dentinários com o grau de sensibilidade relatado pelo paciente em diferentes situações clínicas.

Inicialmente, a intenção desse estudo consistia em realizar as análises e correlações acima descritas por meio de réplicas positivas, obtidas a partir da aplicação de um polivinilsiloxano hidrófilo de consistência ultra-leve e uma resina epóxica. Vale esclarecer que, como se salientou no capítulo Resultados, não foi possível a obtenção de réplicas positivas de qualidade como ocorreu no estudo in vitro. 
Vale considerar que a utilização de siliconas de adição associadas à resinas epóxicas mostrou resultados bastante favoráveis em inúmeros estudos $^{50,5,28,25,54,122,124,2,8,4,125,14,106,127,11,9,10,107,195,27,33,13,49,80,62,128,29,36,77,57,70,110}$. Além disso, esses materiais são compatíveis entre si e proporcionam réplicas de alta qualidade 27,73 .

Nesse estudo in vivo, contudo, obteve-se uma reprodução insatisfatória dos detalhes da superfície da dentina pelas réplicas positivas que pode ser atribuída:

- à contaminação do molde por saliva e/ou fluido gengival, visto que nenhum agente de limpeza foi utilizado para desinfecção do molde antes do vazamento da resina epóxica. No estudo in vitro, a desinfecção não foi necessária por tratar-se de discos de dentina;

- à dificuldade em controlar a umidade local, proveniente do próprio substrato dentinário, e também do sulco gengival, embora o material de moldagem utilizado tivesse características hidrófilas. Mesmo utilizando-se jato de ar até que o material de moldagem fosse acomodado sobre a superfície, a pressão do fluido dentinário pode ter impedido a penetração profunda do material no interior dos túbulos, e deu origem aos diferentes padrões de imagem, inclusive da réplica de gotículas de fluído dentinário, visualizadas na Figura 10. Tal evento, relatado por BARNES ${ }^{7}$ em 1979, foi confirmado, mais recentemente, por BEVENIUS; LINDSKOG; HULTENBY ${ }^{10}$, 1994. Essa ocorrência poderia ter sido contornada com a utilização de anestesia local, como sugerem alguns autores ${ }^{2}$, mas não utilizada nesse estudo por motivos já discutidos. No estudo in vitro, os discos de dentina estavam, além de levemente desmineralizados, livres de qualquer umidade, o que permitiu que o material de moldagem penetrasse profundamente no interior dos túbulos dentinários formando tags retorcidos; 
- ao proporcionamento inadequado da resina epóxica, que não favoreceu a reprodução dos detalhes mínimos da superfície dentinária in vivo, como se pode observar nas fotomicrografias dos Grupos 1 e 2. No estudo in vitro, o condicionamento com ácido cítrico não só promoveu a limpeza da superfície, bem como proporcionou a fiel reprodução desses detalhes. Essa possibilidade foi também apontada por ABSY; ADDY, $\mathrm{ADAMS}^{2}$, em 1989, os quais afirmaram que a técnica de réplica é mais eficiente quando existem mais detalhes na superfície.

Outras causas menos prováveis estariam relacionadas à produção de artefatos (bolhas, como as vistas nas Figuras 11C e 11D), decorrentes da maneira de vazar-se o molde, já que não foram utilizados vibradores e nem vácuo, como sugerem outros autores ${ }^{50,86,12}$.

Assim sendo, os resultados desse trabalho foram obtidos a partir de réplicas negativas, ou seja, do molde metalizado e observado diretamente no MEV, cuja discussão se segue.

\section{GRUPO 1}

Os participantes desse grupo apresentavam dentes caninos e/ou pré-molares com grau de hiperestesia dentinária aos estímulos táctil (sonda) e térmico evaporativo (jato de ar) correspondente a, no mínimo, 3cm na EVA para serem considerados hiperestésicos, sendo o estímulo jato de ar o responsável pelos maiores graus de sensibilidade naquele momento (Figura 5.1)

As fotomicrografias das réplicas negativas representativas desse grupo (Figuras 11 a 18) mostraram que, no baseline, quando da mensuração do grau de sensibilidade inicial, as superfícies dentinárias apresentavam grande número de túbulos dentinários expostos, condizentes com as características de dentina hiperestésica, conforme estudos realizados por ABSI; ADDY; ADAMS², em 1989, 
OYAMA; MATSUMOTO ${ }^{86}$, em 1991, RIMONDINI; BARONI; CARASSI108, em 1995 e, ainda, por YOSHIYAMA ${ }^{133}$, em 1989 e YOSHIYAMA ${ }^{134}$, em 1990.

Após a aplicação do agente dessensibilizante à base de oxalato de potássio $\left(\mathrm{Oxa}-\mathrm{Gel} \mathrm{\Theta}^{\circledR}\right)$, todos os pacientes relataram uma considerável diminuição no grau de sensibilidade, prevalecendo o jato de ar com os maiores índices de sensibilidade.

O oxalato de potássio, como já se salientou, é um agente anti-hiperestésico com eficácia comprovada em inúmeros estudos laboratoriais ${ }^{47,92,91}$, e clínicos ${ }^{82,24,102,74,75}$.

Quando se observam as fotomicrografias referentes ao final das quatro aplicações do agente dessensibilizante, apesar da melhora no desconforto relatada pelos pacientes, os túbulos dentinários ainda aparecem expostos, sem a presença de cristais de oxalato de cálcio obstruindo os túbulos dentinários, exceto a imagem da Figura 12B, em que algum resquício da aplicação do oxalato de potássio pode ser observado. Essa ocorrência pode ser explicada pelo procedimento de moldagem para obtenção das réplicas.

No Grupo 1, o grau de sensibilidade foi mensurado imediatamente após a quarta aplicação do agente dessensibilizante e antes dos procedimentos de moldagem. Nessa etapa, a "primeira moldagem" para remoção de debris da superfície não foi feita, justamente devido à presença do agente anti-hiperestésico. Contudo, realizaram-se duas moldagens, sendo uma para obtenção da réplica positiva e outra, para a réplica negativa. Como a moldagem para obtenção da réplica positiva foi feita inicialmente, é provável que tal procedimento tenha removido a camada superficial de Oxa-Gel ${ }^{\circledR}$ e, assim, não foi possível observar-se a interação desse agente com a superfície da dentina com a mesma clareza que se obteve no estudo in vitro. Por outro lado, a presença do agente dessensibilizante nesse 
primeiro molde pode, ainda, ter impedido que a resina epóxica copiasse os detalhes da superfície.

Um aspecto importante com relação às técnicas de réplica a serem aplicadas in vivo consiste na dificuldade em padronizar-se o local de observação para comparação das imagens em diferentes momentos, visto que uma das aplicações dessa técnica seria, justamente, possibilitar o acompanhamento in vivo das modificações da superfície da dentina. GEROULD ${ }^{40}$, em 1944, relatou a dificuldade em reconhecer as mesmas áreas a serem comparadas. A fim de garantir a observação de uma mesma área, ABSY; ADDY; ADAMS², em 1989, traçaram uma marca na superfície dentinária

WESTERGAARD; PALLESEN; HOLMEN ${ }^{127}$, em 1993, ressaltaram a dificuldade em comparar as imagens obtidas das réplicas iniciais e após o período de quatro meses, quando não foi possível reencontrar as estruturas de esmalte observadas nas réplicas iniciais. Além disso, após o período adicional de 8 meses, o esmalte pode ser observado somente em áreas localizadas devido ao desgaste, concorrendo, assim, para o aparecimento de túbulos dentinários. Desse modo, a perda de estrutura dentária causou modificações na superfície.

\section{GRUPO 2}

O Grupo 2 constituiu de pacientes que apresentavam dentes caninos e/ou pré-molares com grau de hiperestesia dentinária aos estímulos táctil (sonda) e térmico evaporativo (jato de ar) correspondente a no mínimo $3 \mathrm{~cm}$ na EVA, sendo que o estímulo sonda causou os maiores graus de sensibilidade no baseline (Figura 5.2).

Nesse grupo, três situações poderiam ocorrer: a primeira seria a diminuição do grau de sensibilidade, e as outras, a manutenção ou a exacerbação do 
desconforto. A confirmação dessas expectativas resultaria da observação das modificações na superfície dentinária in vivo.

Verificou-se que, na maioria dos casos, houve uma diminuição do grau de sensibilidade em relação a um e/ou outro estímulo, após o período de quatro semanas, sem que qualquer tratamento fosse utilizado.

A situação ideal, ou seja, a diminuição do número de túbulos dentinários coincidente com a diminuição do desconforto relatado pelos pacientes foi observada, o que poderia caracterizar a dessensibilização natural, como descrito por alguns autores $^{66,89,85,129}$.

Ao contrário do que se poderia esperar, no caso referente às Figuras $22 \mathrm{~A} e$ 22B, a superfície da dentina teve as características modificadas pela presença de grande quantidade de túbulos dentinários após o período de quatro semanas, mesmo o paciente tendo relatado diminuição do desconforto.

Tal resultado não pode ser totalmente atribuído ao denominado "efeito placebo", pois o placebo é um produto composto de ingredientes inertes, sem qualquer substância ativa e, nesse grupo, nenhum produto foi utilizado. É importante considerar que esses pacientes estavam cientes de que o grau de sensibilidade seria apenas monitorado, e, no caso de não ocorrer remissão espontânea da hiperestesia naquele período, o agente dessensibilizante seria, então, aplicado.

Apesar de o placebo apresentar índices de sucesso em estudos de hiperestesia dentinária, a melhora do grau de sensibilidade pode ser atribuída ao fato de o paciente estar participando de um trabalho científico cujo propósito era avaliar um tratamento específico para sua condição clínica. Em outras palavras, essa circunstância pode aumentar sua confiança, diminuir sua ansiedade e, como conseqüência, o resultado pode ser altamente positivo ${ }^{24,119,120}$. Segundo TROWBRIDGE; SILVER ${ }^{118}$, em 1990, o "efeito placebo" é decorrente de interações 
fisiológicas e psicológicas, sendo o relacionamento entre o paciente e o profissional o principal fator de resposta favorável. Além disso, um comportamento emocional positivo e motivado pode ativar o sistema de inibição da dor do organismo, que controla o estímulo doloroso da periferia através da liberação de endorfinas pelo sistema nervoso central. Em estudos de hiperestesia dentinária, a confiança no profissional e o desejo de obter alívio contribuem, sem dúvida, para o "efeito placebo".

Um outro elemento que pode ter influenciado os resultados obtidos nesse grupo seria o denominado "efeito Hawthorne", descrito por WEST et al. ${ }^{126}$, em 1997, para quem esse efeito é uma resposta a procedimentos não interventivos, como o exame clínico. Os pacientes, enquanto participam de um estudo clínico, tornam-se mais criteriosos na sua higienização bucal, pois sabem que serão freqüentemente examinados pelo cirurgião dentista. A melhora no padrão de higiene bucal pode facilitar o acesso da saliva aos túbulos dentinários e favorecer a obliteração dos túbulos pela deposição de cálcio, fosfato e proteínas da saliva. Além disso, como já mencionado, a placa bacteriana, através da liberação de ácidos, pode ser um fator responsável pela hiperestesia dentinária, cujo grau pode diminuir com a melhora da higienização. Resultados semelhantes relacionados ao efeito placebo foram relatados em muitos trabalhos clínicos, entre os quais citam-se os de COOLEY; SANDOVAL ${ }^{24}$, em 1989, HOLBOROW ${ }^{55}$, em 1994, PEREIRA et al. ${ }^{102}$, em 1994, ESTRELA et al. ${ }^{34}, 1996$ e MARTINELI ${ }^{74}$, em 1999. Essas considerações podem ser confirmadas pela simples comparação das fotomicrografias iniciais e finais desse grupo.

Por outro lado, a Figura 19A não pode ser comparada à Figura 19B, que apresentou uma camada amorfa não identificada, responsável, provavelmente, pela diminuição do grau de sensibilidade naquele momento. Similarmente, a presença de 
partículas na Figura 24B deve ter sido a causa da diminuição do desconforto relatada pelo paciente, em comparação à condição inicial, ilustrada pela Figura 24A. Pode-se salientar aqui a dificuldade em se remover as impurezas da superfície de dentina mesmo após os procedimentos realizados.

Nos casos em que o grau de sensibilidade aumentou após esse tempo, seja com o estímulo sonda (Figura 21B) ou o jato de ar (Figura 20B), a comparação dessas fotomicrografias com as iniciais (Figuras $21 \mathrm{~A}$ e $20 \mathrm{~A}$, respectivamente) mostrou um aumento, também, no número de túbulos dentinários, caracterizando a exacerbação da hiperestesia dentinária.

\subsection{CONSIDERAÇOES FINAIS}

A literatura conta com poucos estudos que abordam a técnica de réplica negativa para observação de tecidos moles e/ou duros da cavidade bucal. Mesmo assim, nos trabalhos em que essa técnica foi utilizada, seus autores não só obtiveram resultados considerados satisfatórios, como também apontaram algumas vantagens em comparação com a técnica da réplica positiva. Dentre elas destacamse, principalmente, as seguintes: simplicidade pelo menor número de passos envolvidos, diminuição no tempo de preparação do espécime, redução de $\operatorname{artefatos}^{67}$, inclusive aqueles associados ao preparo de amostras biológicas para o MEV. Dentre outras vantagens estão a preservação das estruturas avaliadas, a possibilidade de utilização várias vezes em intervalos pré-determinados ${ }^{111}$, a não necessidade de extração do elemento dentário ${ }^{4}$ ou da dessecação dos tecidos, um procedimento necessário para observação no $\mathrm{MEV}^{121}$.

Do ponto de vista clínico, os procedimentos que envolvem a obtenção dos moldes são não só bem tolerados pelo paciente, como também requerem materiais que estão freqüentemente disponíveis no consultório dentário ${ }^{17}$. Entretanto, a única 
desvantagem dessa técnica, segundo GRUNDY ${ }^{50}$, em 1971, estaria relacionada com a dificuldade em interpretar a imagem negativa.

Pode-se afirmar que, além das vantagens acima citadas, a réplica negativa atende aos requisitos básicos relacionados por SCHOEN et al. ${ }^{111}$, em 1978, para o desenvolvimento de uma técnica de réplica simples e acessível por ser atraumática e atóxica para os tecidos a serem replicados, exata e precisa na reprodução de detalhes.

Correspondendo a outros requisitos básicos, o material utilizado nessa pesquisa para a obtenção dos moldes polimeriza em curto período de tempo, a remoção da réplica é fácil e não causa distorção, o molde não sofre alterações quando submetido ao procedimento de metalização necessário para observação no MEV e, sobretudo, a réplica proporcionou uma reprodução negativa que pode ser interpretada.

Considerando-se as dificuldades inerentes ao estudo da hiperestesia dentinária, as diferentes técnicas de réplica propostas, as divergências em relação à limpeza da superfície a ser moldada, a dificuldade de padronização das áreas a serem comparadas e, ainda, as próprias características do substrato dentinário, é de fundamental importância que novas pesquisas sejam realizadas em busca de uma técnica de réplica padronizada e de aplicação clínica acessível. 


\section{CONCLUSÕES}

Da avaliação dos resultados obtidos nesta investigação clínica, pode-se concluir que:

1. A técnica de réplica positiva permitiu, in vitro, a reprodução da superfície de discos de dentina, utilizando-se um polivinilsiloxano hidrófilo de consistência ultra-leve e uma resina epóxica.

2. A técnica de réplica positiva permitiu, in vitro, a análise do efeito do oxalato de potássio sobre a superfície de discos dentina com características semelhantes à dentina hiperestésica.

3. A técnica de réplica positiva não apresentou resultados satisfatórios quando aplicada in vivo.

4. A técnica de réplica negativa, obtida a partir de um polivinilsiloxano hidrófilo de consistência ultra-leve, permitiu, in vivo, a análise das características superficiais da dentina hiperestésica.

5. A técnica de réplica negativa permitiu, in vivo, a análise do efeito do oxalato de potássio sobre a superfície da dentina hiperestésica.

6. A técnica de réplica negativa permitiu, in vivo, analisar as modificações da superfície da dentina hiperestésica em um determinado período de tempo, sem qualquer tratamento.

7. A técnica de réplica negativa permitiu, in vivo, correlacionar as características superficiais da dentina quanto à presença de túbulos dentinários com o grau de sensibilidade relatado pelo paciente em diferentes situações clínicas. 
ANEXO 1 
ANEXO 2 


\title{
ANEXO 3
}

\author{
UNIVERSIDADE DE SÃO PAULO \\ FACULDADE DE ODONTOLOGIA DE BAURU \\ DEPARTAMENTO DA DENTÍSTICA, ENDODONTIA E MATERIAIS DENTÁRIOS
}

\section{CARTA DE INFORMACÃO AO PACIENTE}

Título do Projeto: "Avaliação da técnica de réplica para análise in vitro e in vivo das alterações da superfície da dentina hiperestésica e tratada com oxalato de potássio."

Objetivos do Projeto: Neste estudo os dentes com hiperestesia dentinária selecionados serão tratados com o Oxa-Gel ${ }^{\circledR}$, produto comercial à base de oxalato de potássio, com eficácia comprovada em inúmeros estudos clínicos e laboratoriais. Este produto reage com o cálcio da superfície dentária formando cristais que obliteram a entrada dos túbulos dentinários, e o resultado esperado é a redução da sensibilidade ou do desconforto. Antes do tratamento será realizada uma avaliação do grau de sensibilidade, através de uma escala de medida específica, e uma moldagem da superfície dentinária. $O$ tratamento será realizado aplicando-se o gel de oxalato de potássio na superfície dentinária exposta por 3 minutos, em intervalos de sete dias, durante 4 semanas. Ao paciente será pedido que não coma, beba ou enxágüe a boca por 30 minutos após o tratamento. Após a quarta aplicação do produto será realizada outra moldagem, agora da superfície tratada. A efetividade do tratamento para cada material será avaliada através da utilização de uma sonda clínica e da aplicação de um leve jato de ar na superfície do dente sensível para que o paciente registre o nível de desconforto. Será necessário que o paciente retorne após 1, 2, 3 e 4 semanas após o tratamento inicial. É importante esclarecer que nenhum efeito colateral com o uso de ambos produtos foi relatado em estudos realizados anteriormente. Alguns pacientes não serão submetidos a qualquer tipo de tratamento, sendo que somente a avaliação da sensibilidade e as moldagens deverão ser realizadas para acompanhamento da lesão, na primeira consulta e após quatro semanas. Para os pacientes pertinentes a esse grupo que não apresentarem remissão total da hiperestesia dentinária após o período de quatro semanas será oferecido o tratamento para a hiperestesia com oxalato de potássio. $\mathrm{O}(\mathrm{a})$ paciente poderá sentir um gosto desagradável proveniente das soluções e a utilização dos estímulos táctil e jato de ar poderá resultar em um desconforto semelhante ao sentido durante a escovação ou quando se alimenta.

Assim sendo, dou pleno consentimento à Faculdade de Odontologia de Bauru para, por intermédio de seus professores e alunos de pós-graduação, devidamente autorizados, fazer diagnóstico, planejamento, fotografia, moldagens, tratamento e pesquisa em minha pessoa, de acordo com os conhecimentos enquadrados no campo dessa especialidade. Concordo também, que a documentação referente aos exames efetuados e quaisquer outras informações concernentes ao planejamento de diagnóstico e/ou tratamento, constituem propriedade exclusiva desta Faculdade, à qual dou plenos direitos de uso para fins de ensino e divulgação, respeitando os respectivos códigos de ética. Estando disponível, e se necessário for, participarei de futuras reavaliações para controle. 
ANEXO 4

\author{
UNIVERSIDADE DE SÃO PAULO \\ FACULDADE DE ODONTOLOGIA DE BAURU \\ CEP - COMITÊ DE ÉTICA EM PESQUISA
}

\title{
TERMO DE CONSENTIMENTO LIVRE E ESCLARECIDO
}

Título do Projeto: "Avaliação da técnica de réplica para análise in vitro e in vivo das alterações da superfície da dentina hiperestésica e tratada com oxalato de potássio."

Pelo presente instrumento que atende às exigências legais, o(a) senhor(a) identidade no. portador(a) da cédula de em seus mínimos detalhes, ciente dos serviços e procedimentos aos quais será submetido, não restando quaisquer dúvidas a respeito do lido e explicado, firma seu CONSENTIMETO LIVRE E ESCLARECIDO em concordância em participar da pesquisa proposta no que lhe é cabível, conforme CARTA DE INFORMAÇÃO AO PACIENTE.

Fica claro que o paciente ou seu representante legal podem, a qualquer momento, retirar seu CONSENTIMENTO LIVRE E ESCLARECIDO e deixar de participar do estudo alvo da pesquisa ciente que todo o trabalho realizado torna-se informação confidencial guardada por força do sigilo profissional (Art. $9^{0}$ do Código de Ética Odontológica).

O paciente declara também ter recebido uma cópia da CARTA DE INFORMAÇÃO AO PACIENTE e também desta AUTORIZAÇÃO PARA PESQUISA.

Por estarem entendidos e conformados, assinam o presente termo.

Bauru, de de 20

Assinatura do paciente 
ANEXO 5 (frente)

FICHA DE IDENTIFICACÃO

PACIENTE $\mathrm{N}^{\circ}$

Data _ _ _ 1

\section{DADOS GERAIS DO PACIENTE:}

Nome:

Endereço: $\mathrm{n}^{0}$

Bairro CEP Fone

Cidade: Estado Complemento .

Masc.

Data nascimento: Idade

Profissão Fone do Trabalho

Endereço do Trabalho

Pessoa próxima:

Endereço: Fone:

\section{QUESTIONÁRIO DE SAÚDE}

Já teve hemorragia?

Tem alergia a algum alimento, produto odontológico, cosmético ou medicamento?

Teve reumatismo infeccioso, artrite ou artrose?

Sofre ou sofreu de algum distúrbio cardiovascular?

É diabético ou tem familiares diabéticos?

Já desmaiou alguma vez?

Está em tratamento médico?

Está tomando algum medicamento?

Esteve doente ou foi operado nos últimos 05 anos?

Tem hábitos, vícios ou manias?

\section{QUESTIONÁRIO ESPECÍFICO}

Qual o estímulo necessário para que a dor se manifeste (ar, alimentos ou líquidos doces ou gelados, ao escovar os dentes) ?

Já fez algum tipo de tratamento para diminuir esta dor?

Se já fez, quando e qual o tratamento realizado?

Já fez algum tratamento ou cirurgia periodontal ?

Se já fez, a dor existia antes deste tratamento?

Como escova os seus dentes e quantas vezes/dias?

Qual o dentifrício que está utilizando no momento?

Já utilizou algum dentifrício dessensibilizante (Sensodyne, Emoform)?

Se já utilizou, o fez por quanto e há quanto tempo?

Qual o tipo de escova de dentes utilizada (dura, macia, extra-macia) ?

Costuma ingerir com freqüência alimentos e/ou bebidas ácidas ?

Tem o hábito de ranger os dentes ou apertá-los durante o dia ou à noite ?

Tem algum problema de saúde (diabetes, hipertireoidismo, xerostomia, problemas digestivos, acidez)?

Tem algum problema psicossomático como anorexia, bulimia e outros ?

Faz uso de medicamentos (anticonvulsivo, antihistamínico, sedativo, tranqüilizante, antiinflamatório, analgésico, psicotrópico) ou álcool ?

Padrão de higiene oral: ( ) bom ( ) regular ( ) ruim 
ANEXO 6

\section{FICHA DE CONTROLE DAS APLICACÕES}

PROJETO: "Avaliação da técnica de réplica para análise in vitro e in vivo das alterações da superfície da dentina hiperestésica e tratada com oxalato de potássio."

PACIENTE: Ficha:

CONSULTA: _ INICIAL _ _ $\quad$ I SEM

TRATAMENTO: $\quad$ G1 G2

DENTE:

Faça uma marca vertical na linha que corresponda à sua sensibilidade:

Antes do tratamento: (DATA:

SONDA

nenhum desconforto desconforto severo

AR

nenhum
desconforto desconforto severo

Após o tratamento: (DATA:

SONDA

nenhum desconforto desconforto severo

AR

nenhum desconforto desconforto severo

Reações adversas:

Comentários do Paciente: 


\section{ANEXO 5 (verso)}

Eu, declaro que estas informações por mim fornecidas são verdadeiras, sobre as quais assumo inteira responsabilidade.

Assinatura do paciente

DENTES SELECIONADOS PARA PESQUISA:

\begin{tabular}{lll|lll}
15 & 14 & 13 & 23 & 24 & 25 \\
45 & 44 & 43 & 33 & 34 & 35
\end{tabular}




\section{REFERÊNCIAS BIBLIOGRÁFICAS*}

1. ABSI, E.G.; ADDY, M.; ADAMS, D. Dentine hypersensitivity. A study of the patency of dentinal tubules in sensitive and non-sensitive dentine. J. clin. Periodont., v.14, n.5, p.280-4, May 1987.

2. ABSY, E.G.; ADDY, M.; ADAMS, D. Dentin hypersensitivity: the development and evaluation of a replica technique to study sensitive and non-sensitive cervical dentin. J. Clin. Periodont., v.16, n.3, p.190-5, Mar. 1989.

3. ADDY, M; ABSY, E.G.; ADAMS, D. Replication of sensitive dentin. Int. Endod. J., v.26, n.1, p.3-6 ,10-21, Jan. 1993.

4. AKPATA, E.S.; WINTER, P.J. Replication of human occlusal tooth attrition surfaces for scanning electron microscopic study. J. oral Rehab., v.18, n.1, p. 61-7, Jan. 1991.

5. BARNES, I.E. Replica models for the Scanning Electron Microscope. A new impression technique. Brit. dent. J., v.133, n.17, p.337-42, Oct. 1972.

6. BARNES, I.E. Replication techniques for the scanning electron microscope 1. History, materials and techniques. J. Dent.,v.6, n.4, p.327-41, Dec. 1978.

\footnotetext{
* Normas recomendadas para uso no âmbito da Universidade de São Paulo, com base no documento "Referências Bibliográficas: exemplos", emanado do Conselho Supervisor do Sistema Integrado de Bibliotecas da USP, em reunião de 20 de setembro de 1990.
} 
7. BARNES, I.E. Replication techniques for the scanning electron microscope 2 . Clinical and laboratory procedures: interpretation. J. Dent.,v.7, n.1, p.25-37, Mar. 1979.

8. BEVENIUS, J.; HULTENBY, K. In vitro and in vivo replication for scanning electron microscopy of the cervical region of human teeth. Scanning Microsc., v.5, n.3, p.731-40, 1991.

9. BEVENIUS, J.; LINDSKOG, S.; HULTENBY, K. The amelocemental junction in young premolar teeth. A replica study by scanning electron microscopy. Acta Odont. Scand., v.51, n.3, p.135-42, June 1993.

10. BEVENIUS, J.; LINDSKOG, S.; HULTENBY, K. The micromorphology in vivo of the buccocervical region of premolar teeth in young adults. A replica study by scanning electron microscopy. Acta Odont. Scand., v.52, n.6, p.323-34, Dec. 1994.

11. BEVENIUS J. et al. Idiophatic cervical lesions: in vivo investigation by oral microendoscopy and scanning electron microscopy. A pilot study. J. Oral Rehab., v.20, n.1, p.1-9, Jan. 1993.

12.BOZOLLA, J.J.; RUSSELL, L.D. Specimen preparation for scanning electron microscopy. In: Electron microscopy: principles and techniques for biologists. 2. ed. Massachusetts, Jones and Bartlett Publishers, 1999. p.4871. 
13. BRADDY, J.M.; WOODY, R.D. Scanning microscopy of cervical erosion. J. Amer. dent. Assoc., v.94, p.426-9, Apr. 1997.

14. BRAEM, M.; LAMBRECHTS, P.; VANHERLE, G. Stress-induced cervical lesions. J. prosth. Dent., v.67, n.5, p.718-22, May 1992.

15. BRÄNNSTRÖM, M. Sensitivity of dentin. Oral Surg., v.21, n.4, p.517-26, Apr. 1966.

16. BRÄNNSTRÖM, M.; ASTRÖM, A. The hydrodynamics of the dentine; its possible relationship to dentinal pain. Int. dent. J., v.22, n.2, p.219-27, 1972.

17. CALZONETTI, K. J. et al. Ultrasonic root end cavity preparation assessed by an in situ impression technique. Oral Surg., v.85, n.2, p.210-5, Feb. 1998.

18. CAMPS J. et al. Effects of desensitizing agents on human dentin permeability. Amer. J. Dent., v.11, n.6, p. 286-90, Dec. 1998.

19. CARVALHO, Z.; DIAS, K. Avaliação da eficácia de três substâncias no tratamento da hipersensibilidade dentinária. In: ENCONTRO DO GRUPO BRASILEIRO DE PROFESSORES DE DENTÍSTICA, 12 , Recife, 1999. Anais. Recife, GBPD, 1999. /Resumo $n^{\circ} 32 /$

20. CLARK, G. E.; TROULLOS, E. S. Designing hypersensitivity clinical studies. Dent. Clin. N. Amer., v.34, n.3, p.531-44, July 1990 
21. COBB, D.S.; REINHARDT, J.W.; VARGAS, M.A. Effect of HEMA-containing dentin desensitizer on shear bond strength of resin cement. Amer. J. Dent., v.10, n.2, p.62-5, Apr. 1997.

22. COLLAERT, B.; FISCHER, C. Dentine hypersensitivity: a review. Endod. dent. Traumat., v.7, n.1, p.145-52, Feb. 1991.

23. COOFEY, C.T. et al. Analysis of human dentinal fluid. Oral Surg., v.30, n.6, p.8357, Dec. 1970.

24. COOLEY, R. L.; SANDOVAL, V.A. Effectiveness of potassium oxalate treatment on dentin hypersensitivity. Gen. Dent., v.37, n.4, p.330-3, July 1989.

25. COWELL, C.R.; SAXTON, C.A. Assessment of a non-elastomeric polymer for the replication of tooth surface in vivo. J. Dent., v.6, n.3, p.210-6, 1978.

26. CUENIN, M.F. et al. An in vivo study of dentin sensitivity: the relation of dentin sensitivity and the patency of dentin tubules. J. Periodont., v. 62, n.11, p.66873, Nov. 1991.

27. DERRIEN, G.; LE MENN, G. Evaluation of detail reproduction for three die materials by using scanning electron microscopy and two-dimensional profilometry. J. prosth. Dent., v.74, n.1, p.1-7, July 1995.

28. DESPAIN, R.R.; LLOYD, B.A.; BROWN, W.S. Scanning electron microscope investigation of cracks in teeth trough replication. J. Amer. dent. Ass., v.88, n.3, p.580-4, Mar. 1974. 
29. DIETSCH, D.; MOOR, L. Evaluation of the marginal and internal adaptation of different ceramic and composite inlay systems after an in vitro fatigue test. $\mathbf{J}$. Adhesive Dent., v.1, n.1, p.41-56, 1999.

30. DOWELL, P.; ADDY, M. Dentin hypersensitivity - a review: a etiology, symptoms and theories of pain production. J. clin. Periodont.,v.10, n.4, p.341-50, July 1983.

31. DOWELL, P.; ADDY, M.; DUMMER, P. Dentin hypersensitivity: a etiology, differential diagnosis and management. Brit. dent. J., v.158, n.9, p.92-6, Feb. 1985.

32. DUROUX, P.; CIMASONI, G. Dentin hypersensitivity and their treatment: a review of the literature. Disponível na Internet. http;//www.ncbi.nlm.nih.gov. 04 maio 1999.

33. EKFELDT, A.; FLÖYSTRAND, F.; ÖILO, G. Replica techniques for in vivo studies of tooth surfaces and prosthetic materials. Scand. Dent. J., v.93, n.6, p.560-5, 1995.

34. ESTRELA, C et al. Análise da redução da dor pós-tratamento da hipersensibilidade dentinária. Rev. Odont. Brasil Central- ROBRAC, v.6, n.17, p.4-9, 1996. 
35. FACQ, J.M.; VOLPE, A.R. In vivo actual abrasiveness of three dentifrices against acrylic surfaces of veneer crows. J. Amer. dent. Ass., v.80, n.2, p.317-23, Feb. 1970.

36. FERRARI, M. et al. Clinical evaluation of an one-bottle bonding system for desensitizing exposed roots. Amer. J. Dent., v.12, n.5, p.243-9, Oct. 1999.

37.FRANK, R. M. Attachment sites between the odontoblast process and the intradental nerve fiber. Arch. oral Biol., v.13, n.2, p.833-4, July/Dec. 1968.

38. GARBEROGLIO, R.; BRÄNNSTRÖM, M. Scanning electron microscope investigation of human dentinal tubules. Arch. oral. Biol., v.21, n.6, p.355-62, June 1976.

39. GARONE FILHO, W. Lesões cervicais e hipersensibilidade dentinária. In: TODESCAN, F. F.; BOTTINO, M. A. Atualização na clínica odontológica. São Paulo, Artes Médicas, 1996. Cap.3, p. 35-75.

40.GEROULD, C.H. Ultramicroestructures of the human tooth as revealed by the electron microscope. J. dent. Res., v.23, n.4, p.239-45, Aug. 1944.

41. GILLAM, D.G. Clinical trial designs for testing of products for dentin hypersensitivity - a review. J. West Soc. Periodont., v.41, n.2, p.37-46, 1997.

42. GILLAM, D.G.; MORDAN, N.J.; NEWMAN, H.N. The dentin disc surface: a plausive model for dentin physiology and dentin sensitivity evaluation. Adv. Dent. Res., v.11, n.4, p.487-501, Nov. 1997. 
43. GILLAM, D. G. et al. Comparision of two desensitizing agents for the treatment of cervical dentine sensitivity. Endod. dent. Traumat., v.13, n.1, p.36-9, Feb.1997.

44. GILLAM, D. G. et al. Efficacy of a potassium nitrate mouthwash in alleviating cervical dentine sensitivity (CDS). J. clin. Periodont., v.23, n.11, p.993-7, Nov. 1996.

45. GILLAM, D.G. et al. Scanning electron microscopy (SEM) investigation of selected desensitizing agents in the dentin disc model. Endod. dent. Traumat., v.15, p.198-204, 1999.

46. GILLAM, D.G. et al. The effects of oxalate-containing products on the exposed dentin surface: a SEM investigation. J. oral Rehab., v.28, n. 11, p.1037-44, Nov. 2001.

47. GRENHILL, J. D.; PASHLEY, D. H. The effects of desensitizing agents on the hydraulic condutance of human dentin in vitro. J. dent. Res., v.60, n.3, p.68698, Mar. 1981.

48. GROSSMAN, L.I. A systematic method for the treatment of hypersensitive dentin.

J. Amer. dent. Ass., v.22, p.592-602, Apr. 1935. 
49. GROSSMAN. E.S.; MATEJKA, J.M. Amalgam marginal quality assessment: a comparison of seven methods. J. oral Rehabil., v.24, n.7, p.496-505, July 1997.

50. GRUNDY, J.R. An intra-oral replica technique for use with the scanning electron microscope. Brit. dent. J., v.130, n.2, p.113-7, Feb. 1971.

51. GYSI, A. An attempt to explain the sensitiveness of dentine. Brit. dent. Res., v.43, p.865-68, 1900 apud COX, C.F. Etiology and treatment of root hypersensitivity. Amer. J. Dent., v.7, n.5, p.260-70, Oct. 1994.

52. HANSSON, R. E.; BYE, F.L.; SMITH, B. A. Four different pain rating scales used to evaluated dentin hypersensitivity. J. dent. Res., v.67, p.282, 1988. Special issue. /Abstract 1433/

53. HERNANDEZ, F. et al. Clinical study evaluating the desensitizing effect and duration of two commercially available dentifrices. J. Periodont., v.43, n.6, p.367-72, June 1972.

54. HIRVONEN, T.J.; NÄRHI, M.V.O.; HAKÜMAKI, M.O.K. the excitability of dog pulp nerves in relation to the condition of dentin surface. J. Endod., v.10, n.7, p.294-8, July 1984.

55. HOLBOROW, D.W. A clinical trial of a potassium oxalate system in the treatment of sensitive root surfaces. Arch. oral Biol., v.39, p.134s, 1994. Supplement. 
56. HOLLAND, G.R. et al. Guidelines for the design and conduct of clinical trials on dentin hypersensitivity. J. clin. Periodont., v.24, n.11, p.808-13, Nov. 1997.

57. ITTHAGARUN, A.; TAY, F. Self-contamination of deep dentin by dentin fluid. Amer. J. Dent., v.13, n.4, p.195-200, Aug. 2000.

58. JAIN, P. et al. Dentin desensitizing agents: SEM and $x$-ray microanalysis assessment. Amer. J. Dent., v.10, n.1, p.21-6, Feb. 1997.

59. JENSEN, M. E.; DOERING, J. V. A comparative study of two clinical techniques for treatment of root surfaces hypersensitivity. Gen. Dent., v.35, n.2, p.128-32, Mar./Apr. 1987.

60. KAUFMAN, H. W.; KLEINBERG, I. Design and statistical aspects of the management of clinical trials to assess antihypersensitivity product efficacy. Arch. oral Biol., n.39, p.97s-100s, 1994. Supplement.

61. KERNS, D.G. et al. Dentinal tubule occlusion and root hypersensitivity. J. Periodont., v.62, n.7, p.421-8, July 1991.

62. KHAN, F. et al. Dental cervical lesions associated with occlusal erosion and attrition. Aust. dent. J., v.44, n.3, p.176-86, Sept. 1999.

63. KNIGHT, N. N. et al. Hypersensitive dentin: testing of procedures for mechanical and chemical obliteration of dentinal tubuli. J. Periodont., v.64, n.5, p.366-73, May 1993. 
64. KRAMMER ,I.R.H. The relationship between dentine sensitivity and movements in the contents of the dentinal tubules. Brit. dent. J., v.98, n.11, p.391-2, June 1955.

65. KRAUSER, J.T. Hypersensitive teeth. Part I: etiology. J. prosth. Dent., v.56, n.2, p.153-6, Aug. 1986.

66. KRAUSER, J.T. Hypersensitive teeth. Part II: treatment. J. prosth. Dent., v.56, n.3, p.307-11, Sept. 1986.

67.KUSY, R.P.; LEINFELDER, K.F. In situ replication techniques: I. Preliminary screening and the negative replication technique. J. dent. Res., v.56, n.8, p.925-32, Aug. 1977.

68. LAMBRECHTS, P.; Van STEMBERGHE, D.; VANHERLE, G. A new in vivo replica technique for scanning electron microscope study of dental plaque morphology. J. clin. Periodont., v.9, n.3, p.252-6, May 1982.

69. LAMBRECHTS, P.; VANHERLE, G.; DAVIDSON, C. An universal and accurate replica technique for scanning electron microscope study in clinical dentistry. Microscopica Acta, v.85, n.1, p.45-58, Sept. 1981.

70. LEONARD JUNIOR., R.H. et al. Nightguard vital bleaching and its effect on enamel surface morphology. J. Esthetic Rest. Dent., v.13, n.2, p.132-9, 2001. 
71.LING, T.Y.Y.; GILLAM, D.G. The effectiveness of desensitizing agents for the treatment of cervical dentine sensitivity (CDS) - a review. J. West Soc. Periodont., v.44, n.1, p.5-12, 1996.

72. LING, T.Y.Y. et al. An investigation of potential desensitizing agents in the dentine disc model: a scanning electron microscopy study. J. oral Rehab., v.24, n.3, p.191-203, March 1997.

73. MANDIKOS, M.N. Polyvinil siloxane impression materials: an update on clinical use. Austr. Dent. J., v.43, n.6, p.428-34, Dec. 1998.

74. MARTINELI, A.C.B.F. Avaliação da hiperestesia dentinária após tratamento com diferentes formulações à base de oxalato de potássio, utilizando-se um placebo como controle. Bauru, 1999. 155p. Dissertação (Mestrado) Faculdade de Odontologia de Bauru, Universidade de São Paulo.

75. MARTINELI, A.C.B.F.; PEREIRA, J.C. Treating dentin hypersensitivity with potassium oxalate: a one-year evaluation. J. dent. Res., v.79, p.361.2000. Special issue /Abstract 1740/

76. MATERIAIS de moldagem: atualização. Dent. Adv., v.8, n.8, p.1-5, set. 2001.

77. MITCHELL, C.A.; ABBARIKI, M., ORR, J.F. The influence of luting cement on the probabilities of survival and modes of failure of cast full-coverage crows. Dent. Mat., v.16, n.3, p.198-206, May 2000. 
78. MIXSON, J.M. et al. Surface morphology and chemical characterization of abrasion/erosion lesions. Amer. J. Dent., v.8, n.1, p.5-9, Feb. 1995.

79. MONGIORGI, R.; PRATI, C. Mineralogical and crystallographical study of gamacalcium oxalate on dentine surfaces in vitro. Arch. oral Biol.,v.39, p.152S. 1994. Supplement.

80. MORGAN, L.A.; MARSHALL, G. A scanning electron microscopic study of in vivo ultrasonic root-end preparations. J. Endod., v.25, n.8, p.587-70, Aug. 1999.

81. MORRIS, M.F.; DAVIS, R.D., RICHARDSON, B.W. Clinical efficacy of two dentin desensitizing agents. Amer. J. Dent., v.12, n.2, p.72-6, 1999.

82. MUZZIN, K. B.; JOHNSON, R. Effects of potassium oxalate on dentin hypersensitivity in vivo. J. Periodont., v.60, n.3, p.151-8, Mar. 1989.

83. ORCHARDSON, R.; COLLINS, W. J. N. Clinical features of hypersensitive teeth. Brit. dent. J., v.162, n.7, p.253-6, Apr. 1987.

84. ORCHARDSON, R.; GILLAM, D.G. The efficacy of potassium salts as agents for treating dentin hypersensitivity. J. Orofacial Pain, v.14, p.9-19, 2000.

85. ORCHARDSON, R. et al. Dentine hypersensitivity into the 21 st century. Arch. oral Biol., v.39, p.113S-19S, 1994. Supplement.

86. OYAMA, T.; MATSUMOTO, K. A clinical and morphological study of cervical hypersensitivity. J. Endod., v.17, n.10, p.500-02, Oct. 1991. 
87. PAMEIJER, C.H.; STALLARD, R.E. A pressureless replica technique for use with the Scanning Electron Microscope. J. dent. Res., v.51, n.6, p.1680, Nov./Dec. 1972.

88. PAMEIJER, C.H.; STALLARD, R.E. Application of replica technique for use with the Scanning Electron Microscope in dental research. J. dent. Res., v.51, n.2, p.672, Mar./Apr. 1972.

89. PASHLEY, D. Mechanisms of dentin sensitivity. Dent. Clin. N. Amer., v.34, n.3, p.449-73, July 1990.

90. PASHLEY, D. Dentin permeability and dentin sensitivity. Proc. Fin. dent. Soc., v.88, 1992. Supplement 1.

91.PASHLEY, D.H.; DEPEW, D.D. Effects of the smear layer, copalite and oxalate on microleakage. Oper. Dent., v.11, p.95-102, 1986.

92. PASHLEY, D.; GALLOWAY, S.E. The effects of oxalate treatment on the smear layer of ground surfaces of human dentine. Arch. oral Biol., v. 30, n.10, p.73137, July/Dec. 1985.

93. PASHLEY, D.H.; ANDRINGA, H.J.; EICHMILLER, F. Effects of ferric and aluminum oxalates on dentin permeability. Amer. J. Dent., v.4, n.3, p.123-6, June 1991. 
94. PASHLEY, D.H.; KALATHOOR, S.; BURNHAM, D. The effects of calcium hydroxide on dentin permeability. J. dent. Res., v.65, n.3, p.417-20, Mar. 1986.

95. PASHLEY, D. et al. Dentin permeability. Effects of desensitizing dentifrices in vitro. J. Periodont.,v.55, n.9, p.522-5, Sept. 1984.

96. PASHLEY, D. et al. Dentin permeability, dentin sensitivity and treatment through tubule occlusion. J. Endod., v.12, n.10, p.465-74, Oct. 1986.

97. PASHLEY, D. et al. The use of oxalate to reduce dentin permeability under adhesive restorations. Amer. J. Dent., v.14, n.2, p.89-94, Apr. 2001.

98. PEACOCK, J.M.; ORCHARDSON, R. Action potential conduction block of nerves in vitro by potassium citrate, potassium tartrate and potassium oxalate. J. clin. Periodont., v.26, n.1, p.33-7, Jan. 1999.

99. PEARCE, N. X.; ADDY, M.; NEWCOMBE, R. G. Dentine hypersensitivity: a clinical trial to compare 2 strontium desensitizing toothpastes with a conventional fluoride toothpaste. J. Periodont., v.65, n.2, p.113-9, Feb.1994.

100. PEREIRA, J.C. Hiperestesia dentinária: Aspectos clínicos e formas de tratamento. Maxi-odonto Dentística, v.1, n.2, mar./abr. 1995. 24 p. 
101. PEREIRA, J.C.; SEGALA, A.D.; CARVALHO, R.M. Improving dentine reaction with potassium oxalate: S.E.M. study. J. dent. Res., v.75, p.197.1996. Special issue /Abstract 1436/

102. PEREIRA, J.C. et al. Treatment of dentinal hypersensitivity in patients submitted to periodontal procedures. J. dent. Res., v.73, n.4, p.729, Apr. 1994. /Abstract 54/

103. PEREIRA, J.C. et al. Improving the effect of desensitizing agents in condutance of human dentin in vitro. J. dent. Res., v.76, p. 96. 1997. /Abstract 660/

104. PLAGMANN, H. C. et al. A clinical study comparing two high-fluoride dentifrices for the treatment of dentinal hypersensitivity. Quintessence Int., v.28, n.6, p.403-8, June 1997.

105. POURGHADIRI, M.; LONGHURST, P.; WATSON, T.F. A new technique for controlled removal of mottled enamel: measurement of enamel loss. Brit. dent. J., v.184, n.5, p.239-41, Mar. 14, 1998.

106. RADFORD, D.R.; RADFORD, J.R. A SEM study of dentine, plaque and oral mucosa of denture-related stomatitis. J. Dent., v.21, n.2, p.87-93, Apr. 1993.

107. RAVNHOLT, G.; KAABER, S. Surface roughness of oral mucosa and its reproduction in dental materials. J. Dent., v.22, n.3, p.169-74, June 1994. 
108. RIMONDINI, L.; BARONI, C.; CARRASSI, A. Ultrastructure of hypersensitive and non-sensitive dentine. A study on replica models. J. clin. Periodont., v.22, n.12, p.809-92, Dec. 1995.

109. ROSENTHAL, M.W. Historic review of the management of tooth hypersensitivity. Dent. Clin. N. Amer., v.34, n.3, p.403-27, July 1990.

110. SCHMIDLIN, P.R. et al. Tooth substance loss resulting from mechanical, sonic and ultrasonic root instrumentation assessed by liquid scintillation. J. Clin. Periodont., v.28, n.11, p.1058-66, Nov. 2001.

111. SCHOEN, F.J. et. al. Objective evaluation of surfaces microreplication by dental impression materials. J. dent. Res., v.57, n.2, p.283-90, Feb. 1978.

112. SCOTT, D.B.; WYCKOFF, W.G. Studies of tooth surface structure by optical and electron microscopy. J. Amer. dent. Ass., v.39, n.3, p.275-82, Sept. 1949.

113. SELTZER, S. Hypothetic mechanisms for dentine sensitivity. Oral Surg., v.31, n.3, p.388-99, Mar. 1971.

114. SENA, F.J. Dentinal permeability in assessing therapeutic agents. Dent. Clin. N. Amer., v.34, n.3, p.475- 90, July 1990.

115. SHONO, Y. et al. A new oxalate treatment for dentine tubule occlusion. Arch. oral Biol., v.39, p.135S, 1994. Supplement. 
116. SILVERMAN, G.; GINGOLD, J.; CURRO, F.A. Desensitizing effect of a potassium chloride dentifrice. Amer. J. Dent., v.7, n.1, p.9-12, Feb. 1994.

117. THOMAS, H. F. The dentin-predentin complex and its permeability: anatomical overview. J. dent. Res., v.64, p.607-12, Apr. 1985. Special issue.

118. TOWBRIDGE, H. O.; SILVER, D.R. A review of current approaches to in-office management of tooth hypersensitivity. Dent. Clin. N. Amer., v.34, n.3, p. 561-81, July 1990.

119. TURNER, J. A. Placebo effects on pain. Disponível an Internet. http://www. health-line.com/articles/hl950404.htm. 18 abr. 1999.

120. TURNER, J. A. et al. The importance of placebo effects in pain treatment and research. Disponível an Internet. http://www.hsc.missouri.edu/ shrp/ ptwww/courses/assign/turner.html. 18 abr. 1999.

121. ULUSU, T.; ÖZTAS, N.; TULUNOGLU, O. Comparison of the effect of insertion techniques of a resin composite on dentinal adaptation of two visible light-cured bases: direct evaluation versus a replica technique. Quintessence Int., v.27, n.1, p.63-8, Jan. 1996.

122. VOSSEN, M.E.M.H. et al. A rapid scanning electron microscopic replication technique for clinical studies of dental restorations. Dent. Mat., v.1, n.14, p.158-63, Aug. 1985. 
123. WAKABAYASHI, H. et al. Scanning electron microscopic study of dentin walls of the pulp chamber by a replica technique. Oral Surg., v.66, n.2, p.23642, Aug. 1988.

124. WALSH, T.F.; BASU. M.K. Evaluation of replica techniques for the surface ultrastructure of rodent and human palatal mucosa. Arch. oral. Biol., v.22, n.10, p.735-40, 1987.

125. WALSH, T.F.; WALMSLEY, A.D. A new method to assess damaging effects on the gingival tissues of non-surgical instrumentation. J. Clin. Periodont., v.18, n.10, p.785-7, Nov. 1991.

126. WEST, N. X. et al. Dentin hypersensitivity and the placebo response. A comparison of the effect of strontium acetate, potassium nitrate and fluoride toothpastes. J. clin. Periodont., v.24, n.3, p.209-15, Apr. 1997.

127. WESTERGAARD, J.; PALLESEN, HOLMEN,N. Exaggerated abrasion/erosion of human dental enamel surfaces; a case report. Scand. Dent. J., v.101, n.5, p.265-9, Oct. 1993

128. WESTON, G.D.; MOULE, A.J.; BARTOLD, P.M. A scanning electron microscopic evaluation of root surfaces and the guta-persha interface following root-end resection in vitro. Int. End. J., v.32, n.6, p.450-8, Nov. 1999.

129. WICHGERS, T.G.; EMERT, R.L. Dentin hypersensitivity. Gen. Dent., v.44, n.3, p.225-30, May/June 1996. 
130. YAMAMOTO, $\mathrm{H}$. et al. Precipitation of oxalates in dog dentinal tubules in vivo. In: INTERNATIONAL CONFERENCE ON DENTIN/PULP COMPLEX AND THE INTERNATIONAL MEETING ON CLINICAL TOPICS OF DENTIN/PULP COMPLEX., Tokio, 1995. Proceedings. Toquio, Quintessence, 1995. p.278-79.

131. YEATES R, et al. A split-mouth placebo-controlled study to determine the effect of amorphous calcium phosphate in the treatment of dentin hypersensitivity. J. clin. Periodont., v.25, p.687-92,1998.

132. YOSHIYAMA, M. et al. Morphological characterization of tube-like structures in hypersensitive human radicular dentin. J. Dent., v.24, n.1/2, p.57-63, Mar. 1996.

133. YOSHIYAMA, M. et al. Scanning electron microscopic characterization of sensitive vs. insensitive human radicular dentin. J. dent. Res., v.68, n.11, p.1498-1502, Nov. 1989.

134. YOSHIYAMA, M. et al. Transmission electron microscopic characterization of hypersensitive human radicular dentin. J. dent. Res., v.69, n.6, p.1293-7, June 1990. 


\section{Evaluation of a Replica Technique for In Vitro and In Vivo Analyses of the Alterations on the Hypersensitive Dentin Surface Treated with Potassium Oxalate}

The present study was carried out to evaluate, in vitro and in vivo, the characteristics and alterations occurring on the surface of hypersensitive dentin treated with a potassium oxalate-based desensitizing agent using a replica technique associated with the scanning electron microscopy (SEM). The in vitro experiment was performed using dentin discs, their surface having been conditioned with $6 \%$ citric acid, covered with artificial smear layer and divided into 4 quadrants. The smear layer was maintained in quadrant 1 , which was the control for the non-exposed dentin. Quadrants 2, 3 and 4 of each disc were reconditioned with $6 \%$ citric acid, and potassium oxalate was applied to quadrants 3 and 4 . Once again, quadrant 4 was then conditioned with $6 \%$ citric acid. The impression using Aquasil ULV was made, and, 6 minutes later, the disc was removed. After 24 hours, a low-viscosity epoxy resin was poured into the model, and left to polymerize for another period of 24 hours. The dentin discs, models and epoxy resin replicas were metallized for analysis in the SEM. In the in vivo study, the patients whose canines and pre-molars had caries-free cervical lesions, and were sensitive to probe and/or air jet stimuli according to the Analogical Visual Scale (AVS) were selected and divided into 2 groups. At the baseline, after recording the degree of sensitivity in both groups, the surface was cleaned with $1 \%$ sodium hypochlorite, and 3 consecutive impressions were made: the first one to remove the debris, and the other two to obtain positive and negative replicas. The models were stored in a closed, dry and clean environment for 24 hours; then, the epoxy resin was poured into such models. Group 
1 (16 teeth) received 4 applications of $\mathrm{Oxa}-\mathrm{Gel}^{\circledR}$ at 7-day intervals, while in Group 2 (7 teeth) no desensitizing agent was used. After 4 weeks, the degree of sensitivity was assessed following the same procedures used to obtain the impressions and replicas, except the first impression. All the specimens were metallized for analysis in the SEM. As for the in vitro experiment, the comparison between the photomicrographs of the dentin discs and their respective models and replicas showed that this technique can reproduce the characteristics of the dentin surface treated with potassium oxalate. In the in vivo study, the positive replicas did not provide the details as noted in the in vitro investigation. On the other hand, the negative replicas favored an analysis of the hypersensitive dentin surface characteristics, the effect of potassium oxalate on that surface, and the alterations that occurred on the hypersensitive dentin surface of Group 2. The analysis of the photomicrographs made it possible to draw a correlation between the presence of dentinal tubules and the degree of sensitivity reported by the patient in different situations. The results showed that the negative replica technique can be a reliable complementary tool for the clinical evaluation of dentin hypersensitivity. 